DEPAR'TMENT OF THE INTERIOR UNITED STATES GEOLOGICAL SURVEY

GEORGE OTIS SMITH, DIRECTOR

$$
\text { BULLetin } 510-15
$$

\title{
OAL FIELDS OF GRAND MESA AND THE WEST ELK MOUNTAINS, COLORADO
}

BY

WILLIS T. LEE
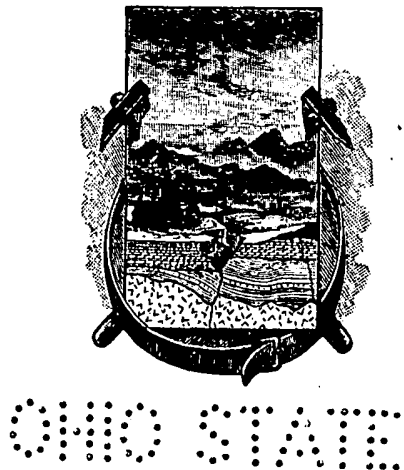

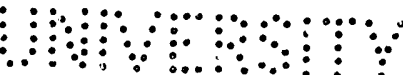

W A SHINGTON

GOVERNMENT PRINTING OFFICE 
QET5

noo. $510-515$

copy 2

؛

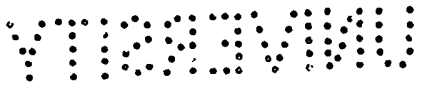




\section{CONTENTS.}

. . . Page.

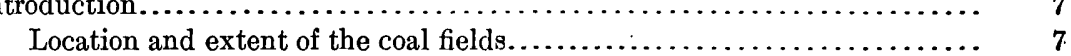

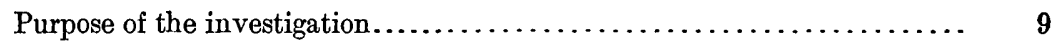

Character and methods of work ................................ 10

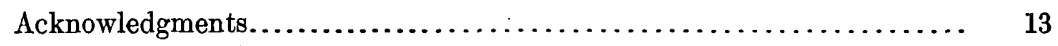

Surface features and their influence on the mining industry............ 13

Grand Mesa field......................................... 13

Floresta field............................................... 16

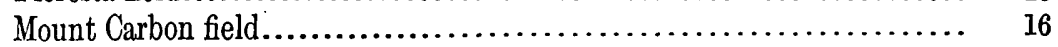

Crested Butte field......................................... 17

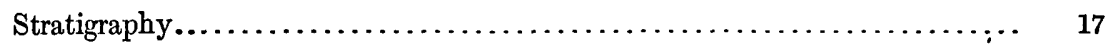

General statement............................................. 17

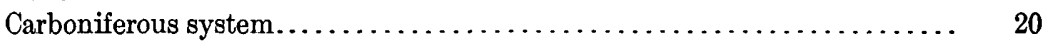

Pennsylvanian (?) series ("Red Beds") ...................... 20

Maroon conglomerate............................... 20

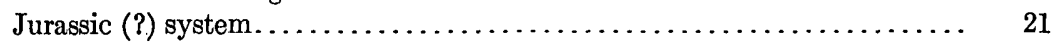

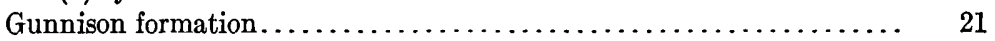

Cretaceous system........................................... 23

Dakota sandstone........................................... 23

Mancos shale.......................................... 25

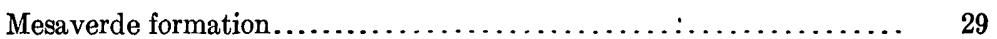

General statement..................................... 29

Rollins sandstone member............................. $\quad 30$

Bowie shale member................................. 32

Paonia shale member................................ 38

Undifferentiated part of the Mesaverde................. 43

Tertiary system....................................... 48

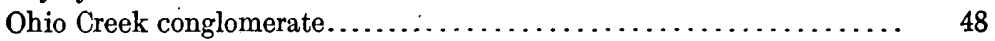

Wasatch ("Ruby") formation............................ 49

Green River formation.......................................

Quaternary system...................................... 52

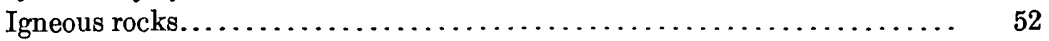

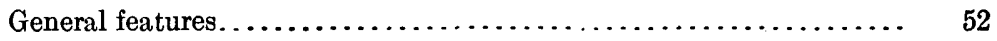

Quartz monzonite porphyry........................... 53

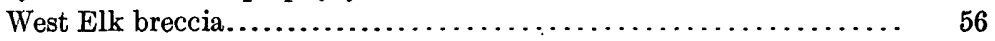

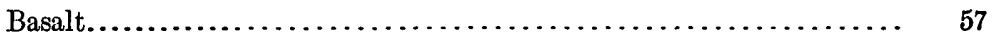

Geologic structure...................................... 57

Relation of the Grand Mesa and West Elk Mountain coal fields to the Uinta

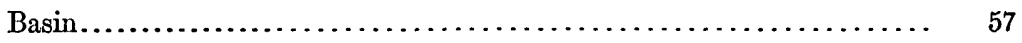

Anthracite quadrangle............................................. 58

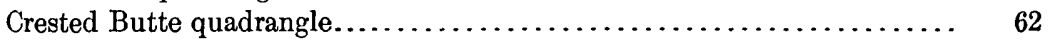

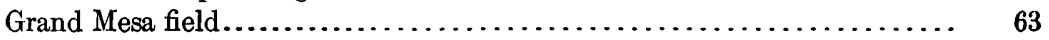

Coal.................................................. 65

Stratigraphic relations and areal distribution of coal-bearing rocks........ 65

Coal in the Mancos shale................................. 65

Coal in the Mesaverde formation........................... 66 
Coal-Continued. Page.

Descriptive details of coal.......................... 67

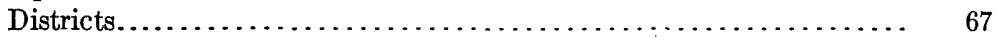

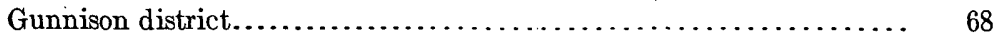

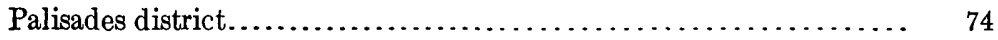

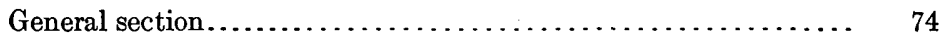

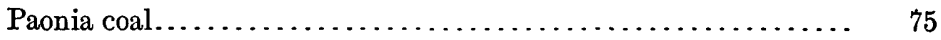

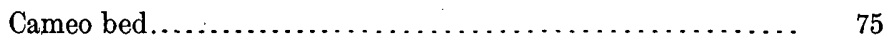

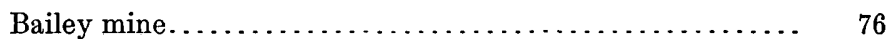

Hall mine............................. ${ }^{7} 77$

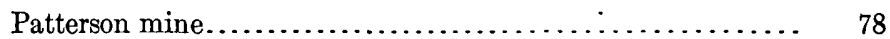

Bowie coal. .............................. 80

Rollins district. . . . . . . . . . . . . . 81

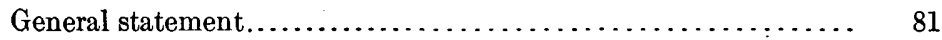

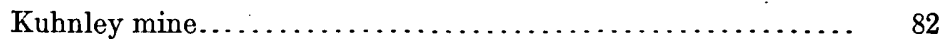

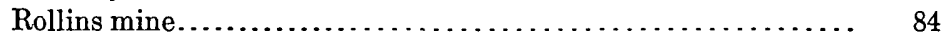

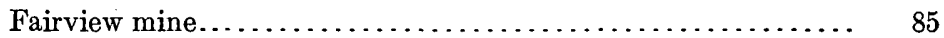

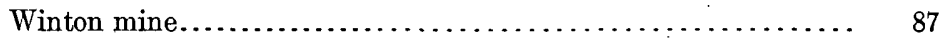

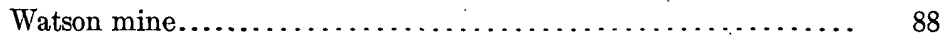

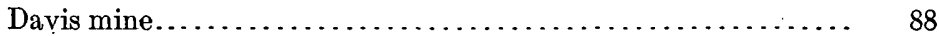

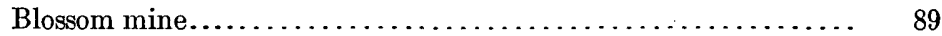

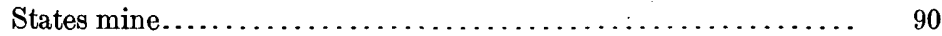

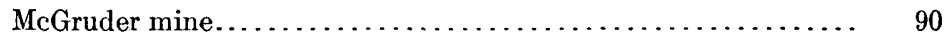

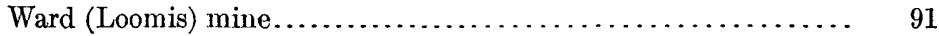

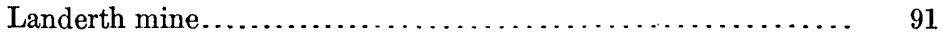

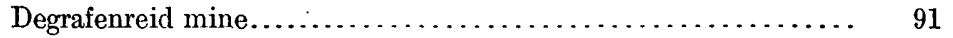

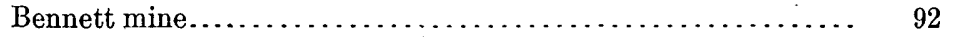

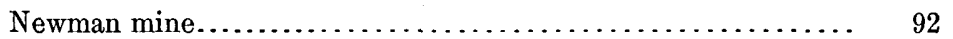

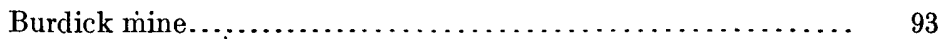

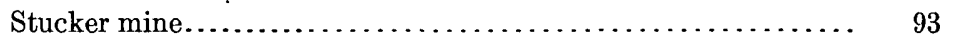

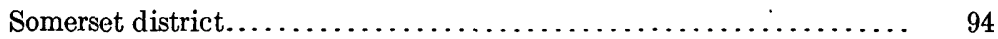

General statement................................... 94

Conine mine................................. 100

Paonia Coal Co.'s mine............................... 101

King mine (old opening) . . . . . . . . . . . . . . . . . . . . . . 102

King mine (new opening) ........................... 103

Other openings near Bowie......................... 105

Somerset mine............................... 106

Sylvester opening.............................. 106

Hawk's Nest mine.............................. 107

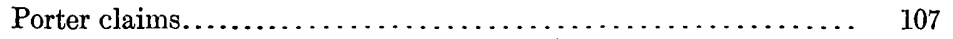

Coal south of Mount Gunnison............................ 110

Coal Creek district. .............................. 112

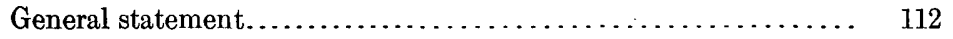

Descriptions of localities........................ 1117

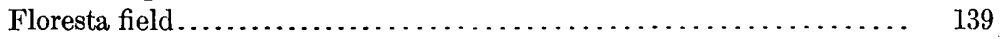

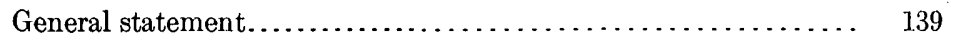

Ruby-Anthracite mine............................ 140

Mount Carbon field................................... 144

General statement............................... 144

Descriptions of localities........................ 148

Crested Butte coal field................................. 168

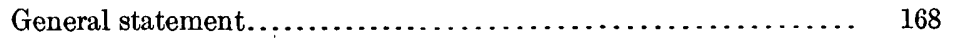

Descriptions of localities.......................... 174 
Coal-Continued. Page.

Quantity of coal........................................ 198

Quality of coal........................................... 199

Collection of samples............................... 199

Chemical analyses..................................... 200

Character of coal relative to origin and to metamorphism.............. 210

Burning of coal at outcrop................................. 216

Surface indications of character of coal......................... 217

Bowie coal.......................................... 218

Paonia coal.................................... 219

\section{ILLUSTRATIONS.}

Puate I. Map and sections of the Grand Mesa and West Elk Mountain coal fields...................................... In pocket.

II. $A$, Promontory south of Palisades, Colo.; $B$, Upper part of Mesaverde formation in canyon of Grand River east of Palisades......

III. $A$, West slope of Grand Mesa, 2 miles north of Kahnah Creek; $B$, Rollins sandstone at type locality, near Rollins mine............

IV. $A$, Mancos shale near Delta, Colo.; $B$, North wall of Gunnison Canyon at mouth of Wells Gulch.............................

V. $A$, West slope of Paine Mesa; $B$, Escarpment of coal-bearing rocks 3 miles south of Palisades, Colo.............................

VI. $A$, Exposure of rocks north of Mount Gunnison; $B$, North wall of Gunnison Canyon at Bowie, Colo.........................

VII. $A$, Canyon of North Fork of Gunnison River near.Somerset; $B$, Typical exposure of coal-bearing rocks east of Paonia, Colo..........

VIII. $A$, Cliff Creek canyon and Mount Lombard; $B$, Robinson Canyon and Mount Gunnison...............................

IX. $A$, Intrusive sheet of igneous rock in Coal Creek canyon; $B$, The Cliff.

$\mathrm{X}$. Landslide in Coal Creek canyon ...........................

XI. The Ruby-Anthracite mine, at Floresta, Colo....................

XII. $A$, Mount Carbon, a laccolith of porphyry intruded into the coal measures; $B$, The Castle, a promontory west of Mount Carbon....

XIII. $A$, Crested Butte;Gibson Ridge, and Mount Wheatstone; $B$, Schuylkill Mountain, near head of Slate River...................

XIV. $A$, Baxter Basin, near head of Slate River; $B$, The Crested Butte mine........................................ 194

XV-XXI. Fossils from the Mesaverde formation. .................. 221-234

FraUre 1. Outline map showing relation of Grand Mesa and West Elk Mountain coal fields to the Uinta Basin

2. Key map of Grand Mesa and West Elk Mountain coal fields, showing location of districts.................................

3. Columnar sections of formations measured in the Grand Mesa field.

4. Sections of coal in the Gunnison district......................

5. Sketch section showing character of coal-bearing rocks at base of the Mancos shale in the Gunnison district and their relation to other formations. 2

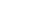
00

\section{2}


Figure 7. Detailed columnar sections of the coal-bearing parts of the Mesaverde formation in the Grand Mesa field, showing the disappearance of the Bowie shale member in the central part of the field..

8. Sections of coal bed in the Bowie shale in the Palisades district...

9. Sections of coal-bearing rocks in the Rollins district of the Grand Mesa coal field.

Page.

10. Columnar sections of the coal-bearing rocks in the Somerset district of the Grand Mesa field........................... 96

11. Sections of coal bed No. 2 in the Coal Creek district........... 116

12. Sections of coal beds Nos. 3, 4, and 5 in the Coal Creek district.... 117

13. Sections of coal bed No. 6 in the Coal Creek district.......... 118

14. Sections of coal bed No. 8 in the Coal Creek district.............. 118

15. Columnar sections measured in the Coal Creek district, showing the occurrence and correlation of the coal beds...................

16. Sections of coal in prospects in the Coal Creek district...........

17. Sections of coal beds in Coal Creek canyon, showing differences in thickness due to rock movements..........................

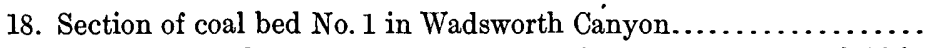

19. Sections of coal measured at the outcrop in the Floresta coal field in. order from west to east.................................

20. Records of drill prospects in the Floresta coal field..............

21. Sections of coal in bed No. 1, Mount Carbon field................

22. Map and section of Mount Carbon, showing faults and their effects

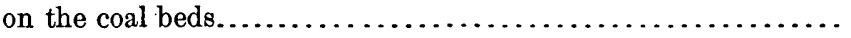

23. Sections of coal in the Alpine mine, Mount Carbon, Colo..........

24. Sections of coal in bed No. 1, Mount Carbon field................

25. Sections of coal in bed No. 2, Mount Carbon field...............

26. Sections of coal in bed No. 2, Mount Carbon field...............

27. Sections of coal in bed No. 2, Mount Carbon field...............

28. Sections of coal in Robinson mine and prospects at east end of the Mount Carbon coal field..............................

29. Columnar sections of coal-bearing rocks measured in the Crested Butte coal field.

30. Sections of coal measured in coal bed No. 1 of the Crested Butte field.

31. Sections of coal measured in coal bed No. 2 of the Crested Butte field.

32. Sections of coal measured in coal bed No. 3 of the Crested Butte coal field.

33. Sections of coal measured in the Crested Butte mine, Crested Butte, Colo., in coal bed No. 3.............................

34. Sketch sections illustrating conditions observed in Crested Butte

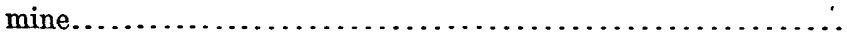

35. Sections of coal in the lower workings of Anthracite mine, Anthra-

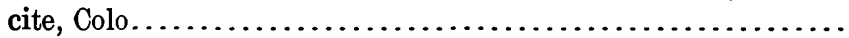

36. Sections of coal measured in prospect openings at the outcrop in Anthracite Mesa.

37. Curve showing relation of character of coal to metamorphism...... 


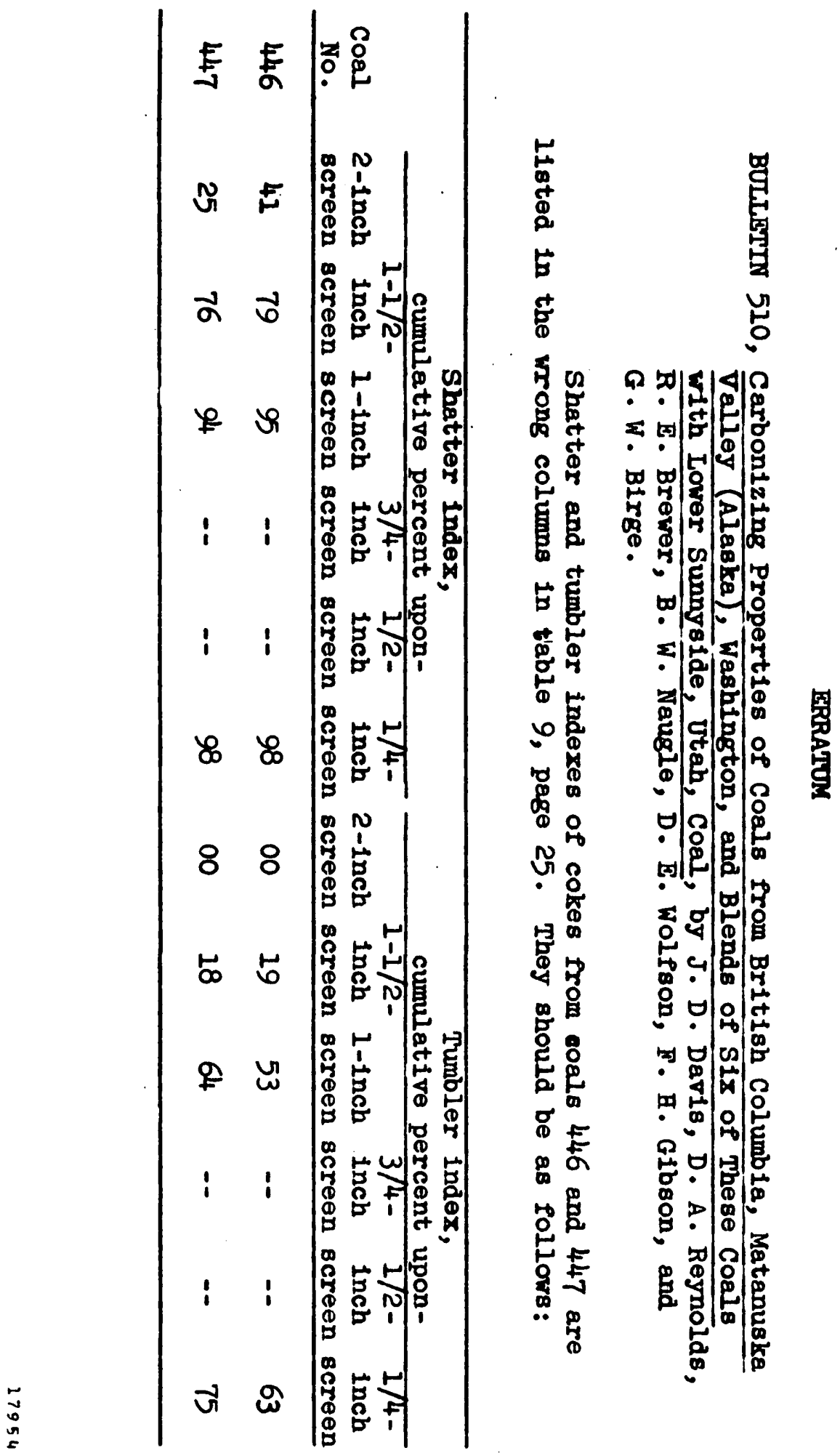




\title{
COAL FIELDS OF GRAND MESA AND THE WEST ELK MOUNTAINS, COLORADO.
}

\author{
By Willis T. Lee.
}

\section{INTRODUCTION.}

\section{LOCATION AND EXTENT OF THE COAL FIELDS.}

The coal fields of Grand Mesa and the West Elk Mountains constitute parts of the Uinta coal region in the Rocky Mountain province as outlined by M. R. Campbell in his map of the coal fields of the United States. This region corresponds in general with the Uinta

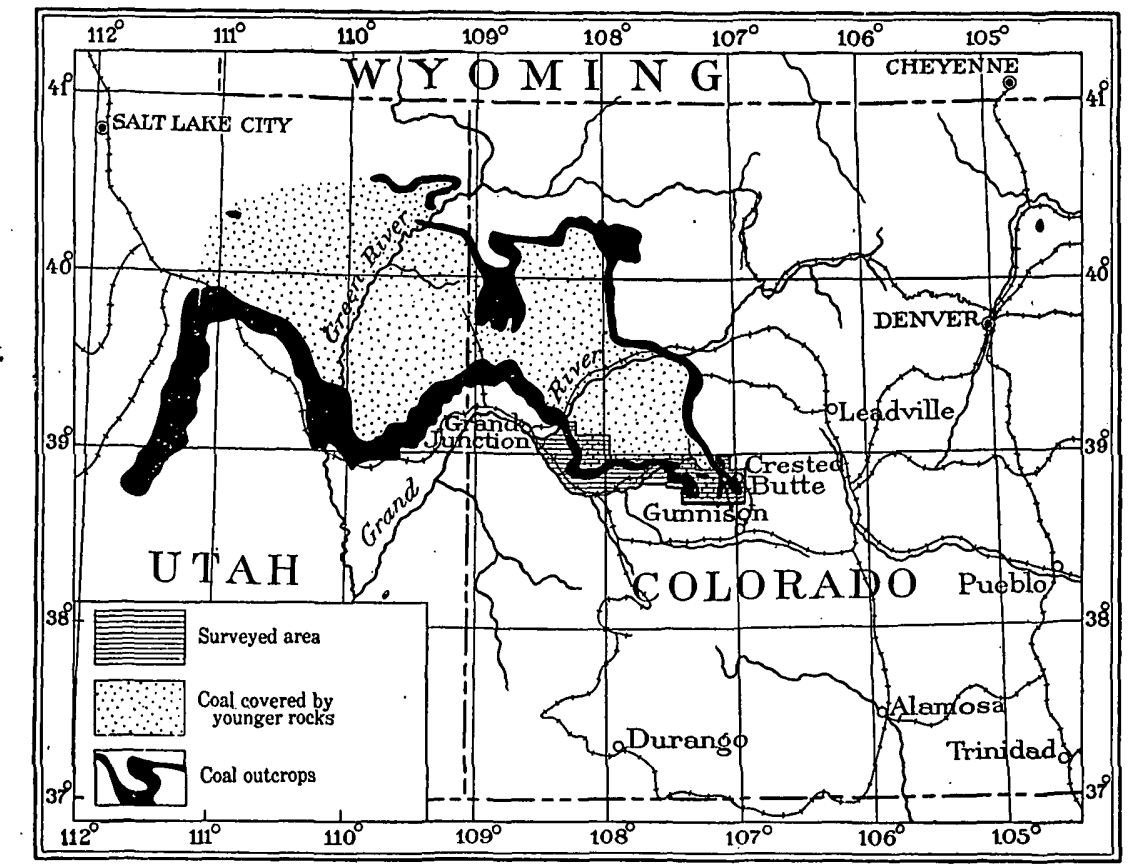

Frgure 1.-Outline map showing relation of the Grand Mesa and West Elk Mountain coal fields to the Uinta Basin.

Basin and lies partly in western-central Colorado and partly in eastern Utah. (See fig. 1.) The part of the Uinta region described in this bulletin is divided into four more or less distinct fields, which may be called Grand Mesa, Floresta, Mount Carbon, and Crested Butte. (See fig. 2.) The Floresta field has been known also as the 
Ruby field and as the Irwin field, but is here called Floresta from the town at which the only mine in the field is located. The Mount Carbon field hàs been known heretofore as the Baldwin area, a name derived from the old Baldwin mine, which is no longer operated. The Crested Butte field has sometimes been called the Slate River field, but since all the producing mines are close to the town of Crested Butte, this name is more appropriate for the field. These fields are separated from one another either by barren areas from which the coal-bearing rocks have been eroded or by areas in which the coal beds are deeply covered by younger rocks. The latter three fields are relatively small and contain isolated areas of coal-bearing rocks, which once constituted parts of the main body of the coal measures of the Uinta Basin, but which were cut off by surface deformation and erosion or by intrusions of igneous rocks during the formation of the West Elk Mountains.

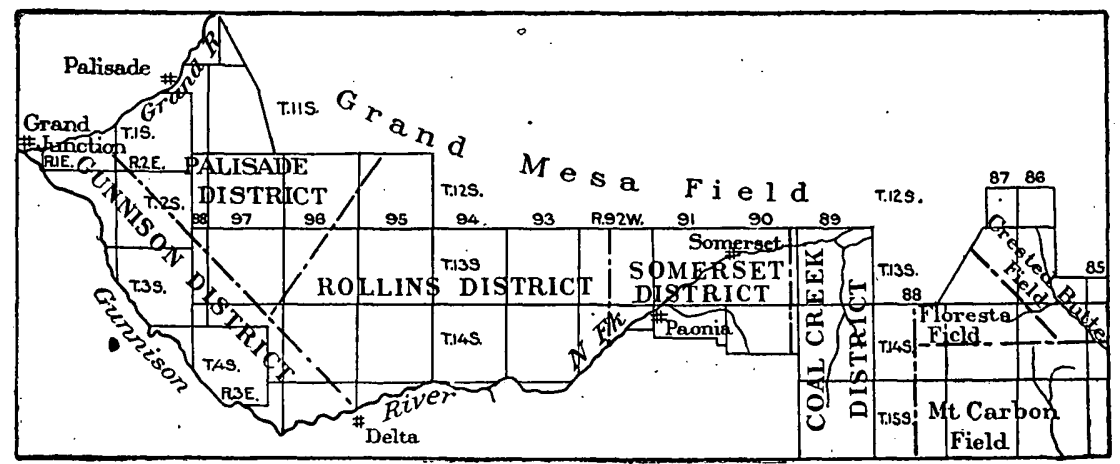

FiguRe 2.-Key map of the Grand Mesa and West Elk Mountain coal fields, showing location of districts.

The Floresta field is small and lies on the north slope of the Anthracite Range. It includes the outcrop, less than 6 miles in length, of the coal-bearing rocks upturned against these mountains. The coal beds dip steeply toward the north and in a short distance pass under a thick cover of younger rocks. The Mount Carbon field lies at the extreme southeast end of the Uinta region. It is named from the mining town that in turn takes its name from Mount Carbon, a laccolithic mass of igneous rock which has been intruded into the coal-bearing strata. It is considerably larger than the Floresta field, and its coal-bearing strata lie more nearly horizontal and at no great depth. On the west flank of the mountain the beds are upturned and an outcrop of coal-bearing rocks about a mile in length is exposed. Toward the west the coal beds disappear beneath a thick cover of igneous rocks that forms the northern spurs of West Elk Peak. Toward the north, except where their continuity is interrupted by igneous intrusives, they extend beneath the surface to the outcrop of the coal in the Crested Butte field. 
The Crested Butte field includes the coal beds that outcrop in the sides of Slate River valley east of Ruby Range. From the sinuous outcrop in the steep bluffs south of this valley the coal beds pass toward the southwest under a cover of younger rocks so thick that the width of the field may be regarded as determined by the distance to which mining can be carried from the outcrop.

The Grand Mesa field is the largest in the area described and derives its name from Grand Mesa, a high table land between Grand and Gunnison rivers. It extends from Palisades on Grand River southeastward to the West Elk Mountains and from the southern edge of Grand Mesa northward without definite delimitation toward the central depression of the Uinta Basin, where the coal lies under a thick cover of younger rocks. Its eastern boundary also is indefinite, for the coal beds extend eastward under a thick cover of igneous rock. In the eastern part of the Grand Mesa field the continuity of the coal beds is interrupted in some places by intrusions of igneous rock, of which Mount Gunnison is a conspicuous example. The coal beds underlie Grand Mesa and crop out in the steep slopes of its western and southern sides. They extend continuously westward into the Book Cliffs coal field, eastward beneath the younger sedimentary and igneous formations into the Floresta, Mount Carbon, and Crested Butte fields, and northward into the Grand Hogback fields. The bituminous coal of Book Cliffs, previously described by Richardson ${ }^{1}$ is traceable through the Grand Mesa field to the anthracite and coking bituminous coals of the Anthracite and Crested Butte quadrangles described by Eldridge, ${ }^{2}$ further details of which are given in this bulletin.

\section{PURPOSE OF THE INVESTIGATION.}

The investigation of these coal fields was undertaken for the purpose, first, of ascertaining the geologic relations of the coal-bearing rocks to other formations; second, of classifying the land by legal subdivisions into coal land and non-coal land; and third, of determining the value of the coal land by ascertaining the thickness of the coal beds, the character and quality of the coal, its accessibility with reference to topographic features, and its location with reference to lines of transportation.

Little geologic work has been done in the Grand Mesa field since the time of the Hayden Survey, nearly 40 years ago, and recent advances in knowledge of the stratigraphy of the coal-bearing rocks of the West required the collection of data by which the coal beds could be

1 Richardson, G. B., The coal field between Grand River, Colorado, and Sunnyside, Utah: Bull. U. S. Geol. Survey No. 316, 1907, pp. 302-320; also, Reconnaissance of the Book Cliffs coal field: Bull. U. S. Geol. Survey No. 371, 1909, 53 pp.

2 Eldridge, G. H., Anthracite-Crested Butte folio (No. 9), Geol. Atlas U. S., U. S. Geol. Survey, 1894. 
correlated with those of other fields. Maps and descriptions of parts of the three smaller fields east of the Grand Mesa field were published in 1894 as Folio 9 of the Geologic Atlas of the United States. During the present investigation the formations in the two quadrangles described in that folio were studied only so far as was necessary to correlate them with the formations examined'beyond the borders of those quadrangles. In the present examination the coal was the principal object of investigation, consequently the formations near the outcrops of the coal beds were examined in greater detail than those at a distance, and special attention was given to the construction of the parts of the map (Pl. I, in pocket) showing these localities. The geology and topography of the areas on the sides of the outcrops have been added from Hayden's Atlas of Colorado and from the Anthracite-Crested Butte folio (No. 9) to show the relations of the coal beds to the general configuration of the country. The geology and topography of that part of the area shown on Plate I, which represents the Anthracite and Crested Butte quadrangles are the same as shown in Folio 9, except for a few slight changes along the outcrop of the coal beds and some additions representing recent economic development.

\section{CHARACTER AND METHODS OF WORK.}

The investigations described in this bulletin extended over a period of three years, during which time much was learned concerning the limitations of certain methods of procedure and their adaptability to local conditions. Many changes in methods of doing classification work have been made since the investigations were begun, and the demand for detailed description and mapping in preference to reconnaissance work in large areas was so much greater at the close of the investigation than at its beginning that the earlier work is, in a sense, already out of date. For these reasons, and in order that the accompanying map may be useful and not misleading, a description of the character of the work and of the methods employed will now be given.

Since the geology of the Anthracite and Crested Butte quadrangles had already been described, little geologic work was done in them beyond that needed to determine the relations of the formations to those in the Grand Mesa field on the west. In this field the rocks are comparatively free from complicated structure and the geologic work consisted principally in determining the age and the areal distribution of the sedimentary formations.

The classification of the land required the location on the ground of established Government corners. When the investigation was begun in the summer of 1907 , little was known of the condition of the 
land surveys in the vicinity of these coal fields. On the assumption that Government corners were to be found on the land as shown by office records, work was begun at Palisades and locations were made with reference to land lines, a method that had proved successful in other fields. Corners were readily found in the lowlands, but in the steep slopes of Grand Mesa near the outcrop of the coal, where exact locations were most essential, few corners could be discovered. The failure to locate corners that were then supposed to exist was attributed to the presence of cliffs which could not be scaled and which thus prevented the traversing of the land lines, and to the dense thickets of brush through which it was difficult to keep a straight course. Some of the section corners on township boundaries were found, but before the close of the first field season it became very evident that few corners could be found in the highlands of the Grand Mesa field. Investigation in the smaller fields east of Grand Mesa during the summer of 1909 proved that the land surveys there were no more accurate than those in the Grand Mesa field. Corners were found in the lowlands but few could be found on the steep wooded slopes except in places where mining development or timber claims had forced resurveys. Apparently the open valleys were surveyed and a few side lines were run in favorable places, but the absence of corners marking the subdivisions of townships is confirmed by the statements of every local surveyor interviewed. A partial explanation, if not justification, of this unsatisfactory character of the surveys is found in the fact that much of this land was "surveyed" as early as 1880, when access to it was more difficult and travel was more dangerous than it is at the present time, and when the great value of the coal beds was unknown.

In the absence of corners near the outcrops of the coal, it became necessary to use some other method of determining locations. Because of the precipitous character of the cliffs it was impracticable in many places to traverse the outcrop of the coal, and since the requirements of classification necessitated mapping on a Land Office base, the corners nearest to the outcrop of the coal were used and the location of the outcrop was determined by triangulation from them, on the assumption that they were located with sufficient accuracy to form a satisfactory base for short-sight triangulation. The work was done with plane-table and open-sight alidade on the scale of 2 inches to the mile. This method appeared to give satisfactory results west and south of Grand Mesa, where corners were found in the lowlands at no great distance from the outcrop of the coal, but as the mapping progressed toward the east it became more and more difficult to find corners : ' orably located, so that a complicated system of triangulation with inadequate base and long sights had to be used. Furthermore, it became evident near the close of the first field season, 
while the work was going on east of Paonia, that some corners were inaccurately located and were therefore of doubtful value, even for short-sight triangulation. The inaccuracy of the land survey was strikingly shown when the location of a point made from one group of corners failed by half a mile to correspond with the location of the same point made from other corners. Accordingly the locations on the map of the Grand Mesa field are only approximately correct. They are probably more nearly correct at the west end of the field than at the east end.

Work in 1907 was discontinued before the Coal Creek district of the Grand Mesa field was examined, and no further work was done in this region until the summer of 1909, when more accurate and reliable methods of location were employed in surveying this district and the three smaller fields east of the Grand Mesa field. During the season of 1909 the triangulation stations of the Hayden Survey were reoccupied and all important points, particularly the land corners that were found, were located with reference to them by means of plane-table and telescopic alidade. In this way the position of the land lines was determined approximately with reference to latitude and longitude. Stadia lines were run where necessary, but the coal fields are so favorably located with respect to the triangulation stations that relatively little stadia work was necessary. For this reason the part of the map east of Coal Creek is much more reliable than the part west of this creek. The northwest corner of sec. 1 and the northeast corner of sec. 36 , T. 14 S., R. 86 W., were located with reference to the Hayden triangulation, and the land net was projected from them.

In 1907, when the work was begun, the requirements called for the rapid examination of large tracts. The coal beds were examined wherever they were exposed, and samples of coal were taken for analysis wherever mines or recent prospect openings were found, but no time was spent in opening coal beds. Therefore it is possible that the Grand Mesa field contains more coal than is indicated on the maps and in the sections. On the other hand, it is not known whether the coal beds are continuous for long distances or are more or less lenticular, and it is possible that the quantity of coal in the fields is actually less than is inferred from the.observations made.

The demand for more exact information regarding the character of individual beds increased so rapidly that in 1909 the greater part of the field work consisted in opening the coals with pick and shovel. For this reason much more is known of the character of the coal beds east of Coal Creek than of those west of that creek. Long stretches were found, however, where the outcrop was so obscured by brush or so completely covered with slide-rock that it was impracticable to prospect the coals. 


\section{ACKNOWLEDGMENTS.}

The work described in this bulletin was done under the general supervision of M. R. Campbell. The writer was assisted during the summer of 1907 in the Grand Mesa field by Charles S. Blair, whose time was devoted partly to geologic investigation and partly to the construction of the topographic map, and by Russell R. Bryan, who was engaged wholly in mapping. The work of constructing the map of this field was done mainly by A. J. Hazelwood. During the summer of 1909 the writer was assisted in the field by E. L. De Golyer, whose time was devoted mainly to topographic mapping and the location of coal prospects, and by J. B. Mertie, who was engaged principally in opening the coal beds and examining coal prospects. The office work in completing the map was done by E. L. De Golyer and H. D. Johnson. The writer wishes to acknowledge his indebtedness to the many mine owners and officials and to the local surveyors of the Grand Mesa and West Elk Mountain region for the information given and for many courtesies extended during the field work.

The invertebrate fossils collected have been identified by T. W. Stanton and the fossil plants by F. H. Knowlton. The correlations of the sedimentary formations made in this paper depend mainly upon their determinations.

\section{SURFACE FEATURES AND THEIR INFLUENCE ON THE MINING INDUSTRY.}

\section{GRAND MESA FIELD.}

The Grand Mesa field is a region of high relief, its major topographic feature being Grand Mesa, a broad table-land, the surface of which is 5,000 feet higher than the valleys on the west and south. It is a part of the zone of transition between broad regional uplifts on the south, from which the coal-bearing and associated rocks have been eroded away, and the eastern part of the Uinta Basin where these rocks are buried under younger formations. The Mancos shale and overlying formations probably once extended over Mesa Inclinado and over a part if not all of the Uncompahgre plateau. This shale is soft and has been the dominant factor in determining the principal lines of erosion. The lowlands in the southern and eastern parts of the field are portions of the great valley eroded along the strike of this shale.

The slopes of the mesa are formed by the erosion of the slightly northeastward dipping strata and are more or less abrupt according to the character of the underlying rocks. The oldest rocks exposed in the field are hard, and because of their resistance to erosion form the canyon walls of Gunnison River. Above these hard strata is the 
soft Mancos shale, overlain in turn by hard sandstones of the Mesaverde formation, which form the lower part of the mesa cliffs, 1,500 to 2,000 feet high (Pl. II, $B$ ). These hard rocks are overlain by easily eroded rocks constituting the Wasatch and Green River formation, and these by the sheet of hard basalt that caps Grand Mesa and forms its rim of cliffs. The influence of the rock formations on the topography is perhaps best illustrated on the accompanying map (Pl. I, in pocket) by means of profiles and by the views of the coalbearing rocks given in the several plates of illustrations.

The northern portion of the eastern part of the Grand Mesa field, which includes the top of Grand Mesa, is not shown on the map and the highlands mapped consist principally of the dissected shelf formed by the layers of hard sandstone of the Mesaverde and capped by the Ohio Creek conglomerate and in some places also by the basal conglomerate of the Wasatch formation. Above this shelf at the extreme east end of the Grand Mesa field rise the outlying peaks of the West Elk Mountains. North Fork of Gunnison River and its tributaries have eroded deep, narrow canyons in these sandstones, but where the streams emerge from them upon the soft underlying shale the canyons widen and merge into the great valley.

The topography of the old surfaces below the level of the coal is of great importance, because the accessibility of the coal and to some extent the value of coal land depend on it, but the details of the topography above the coal are not important to coal development and will not be described. In Grand River valley the coal is at river level, but it rises toward the south until, at the southern point of the mesa, it is more than 4,500 feet above the river; thence eastward it becomes graduially lower and crosses the North Fork of Gunnison River at Somerset.

Where the larger streams cut through the heavy sandstones that overlie the coal the canyon sides are precipitous, as in the canyon of Grand River (PI. II, $A$ ), and in Coal Creek, at the eastern end of the field (Pl. VII, $A$, p. 100). But farther from the lines of vigorous erosion, the cliffs are more or less broken down, and in some places the formations have been evenly graded regardless of hard or soft layers, and this grade has been covered with surface débris, as shown in Plate III, $A$. In other places erosion acting on the massive Rollins sandstone and soft underlying shale has produced such cliffs and rugged slopes as those shown in Plates II, $A$, and III, $B$. In the economic development of the coal these cliffs and graded slopes are of the greatest importance, for the principal coal beds lie immediately above the most conspicuous and persistent sandstone in the Grand Mesa field. Two ways of approach to the coal are thus opened. Roads may be constructed to the base of the cliff and the coal lowered to them by chutes or gravity inclines, or they may be built to the coal 


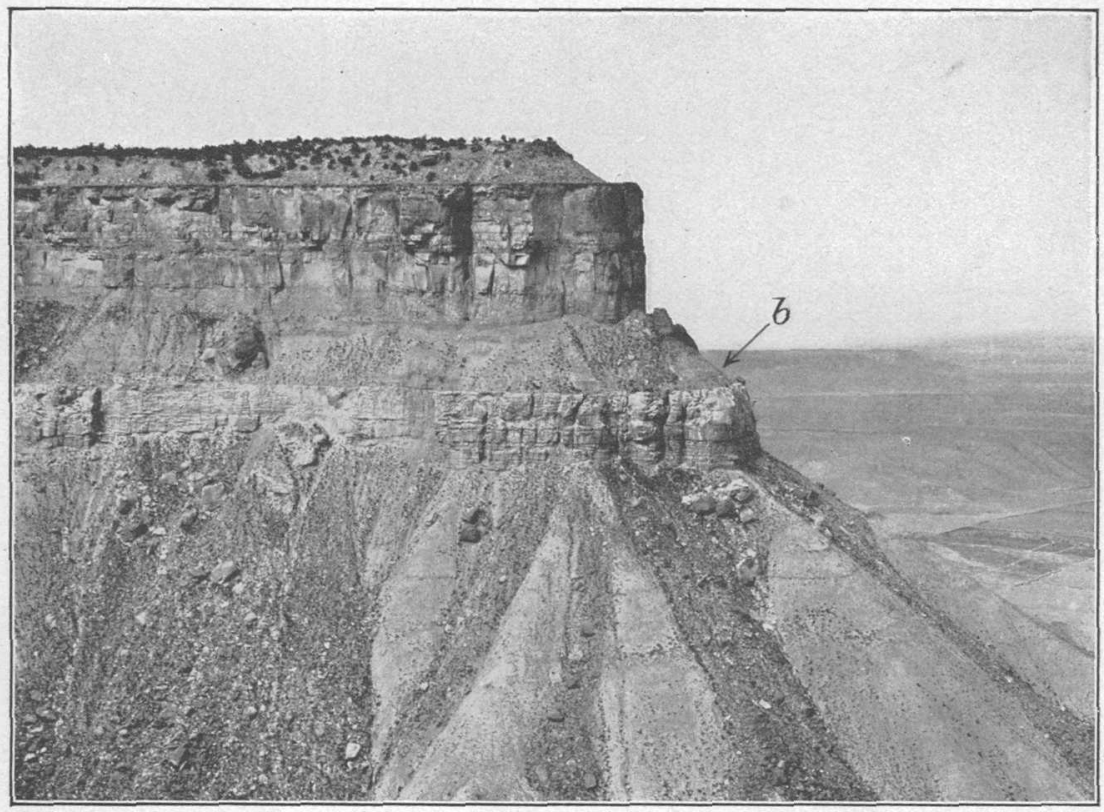

\section{A. PROMONTORY SOUTH OF PALISADES, COLO.}

Altitude, 1,000 feet; showing the upper part of the Mancos shale and the lower part of the Mesaverde formation, including the Rollins sandstone member and the Bowie shale member, with coal near the base $(b)$, and sandstone cliff above.

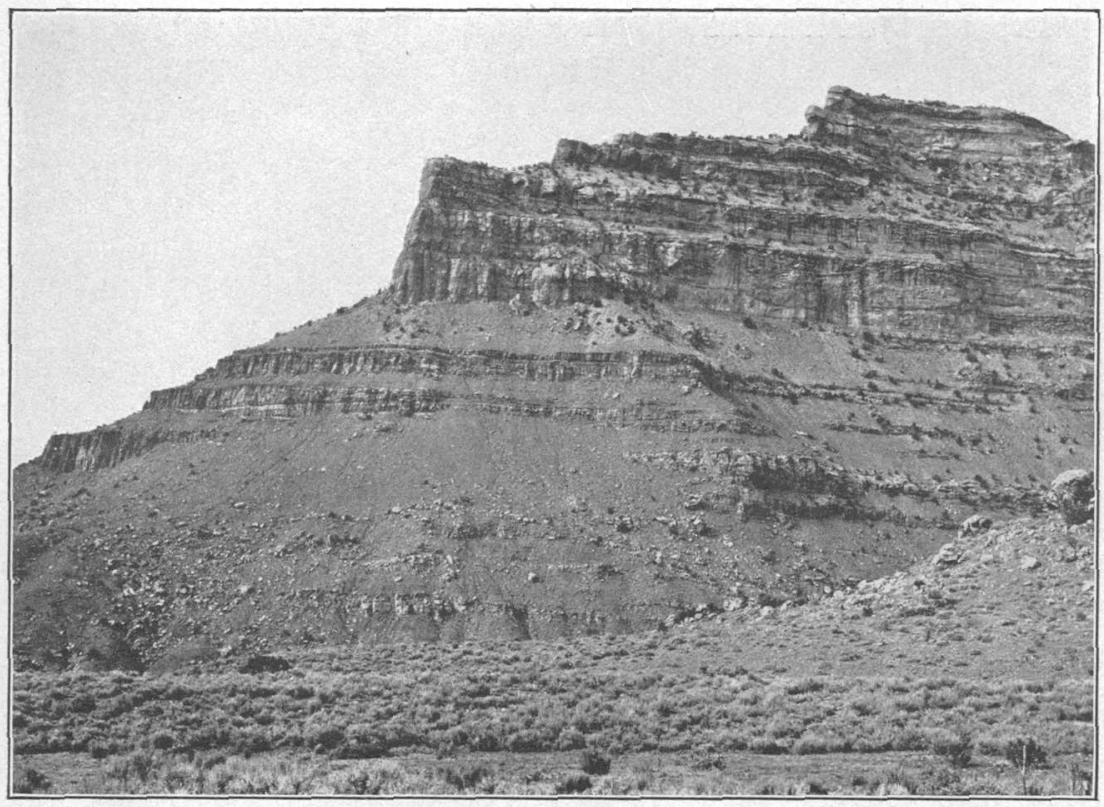

B. UPPER PART OF MESAVERDE FORMATION, 1,500 FEET THICK, IN CANYON OF GRAND RIVER EAST OF PALISADES.

A typical view of the sandstones that overlie the coai-bearing rocks. 


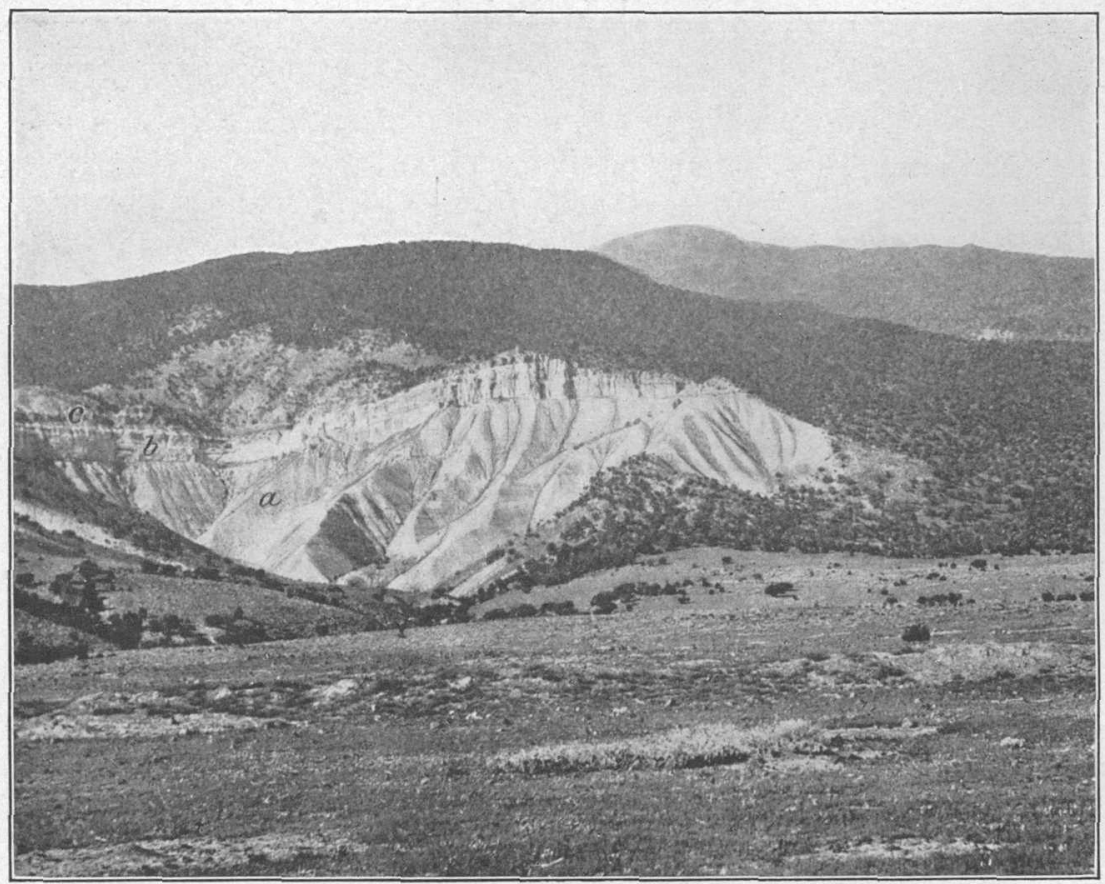

A. WEST SLOPE OF GRAND MESA, 2 MILES NORTH OF KAHNAH CREEK.

A characteristic exposure, showing the slope of the mesa covered with brush except where a washout has exposed the rocks. $a$, Mancos shale; $b$, sandstone at the base of the coal measures; $c$, locality where fossil plants were collected.

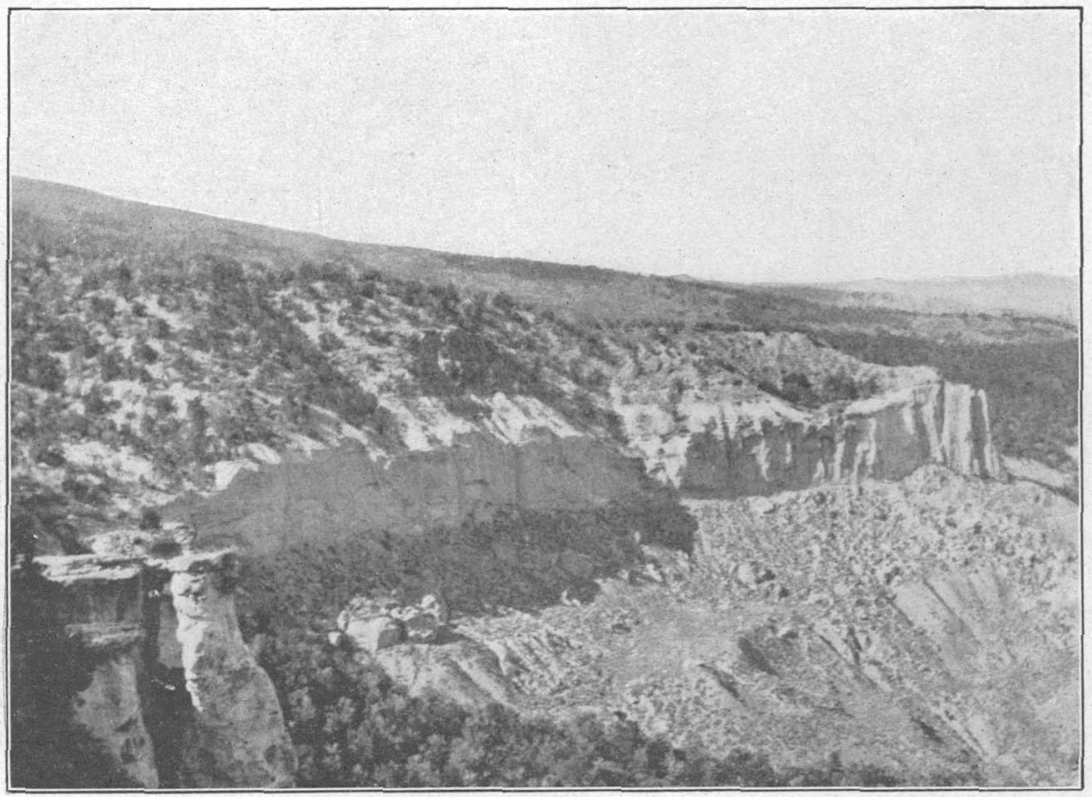

B. THE ROLLINS SANDSTONE AT ITS TYPE LOCALITY NEAR ROLLINS MINE.

The sandstone cliff, 100 feet high, is underlain by Mancos shale and overlain by the fresh-water division of the Mesaverde formation, the rocks of marine and brackish-water origin being absent. The tops of the columns at the left show the hardened upper surface of the sandstone upon which the coal-bearing shale rests with apparent unconformity. 
beds up the slopes that in many places rise from the river to the outcrop of the coal with sufficiently low grade to permit the construction of roads either for wagon or for electric or steam cars. Such a slope is shown in the sky line of Plate $\mathrm{V}, A$, page 32 . These slopes show several stages of development, the oldest of which is well illustrated in Oak Mesa north of Hotchkiss, where the hard sandstones of the Mesaverde and the soft Mancos shale were both brought to the same uniform grade and the surface covered with bowlders of basalt derived from the sheet capping Grand Mesa. This covering of hard bowlders preserves the old grade in some places, but in other places more recent erosion has cut into it and formed a new grade at a lower level.

In some places where the shale was unprotected by' the basalt covering erosion has produced badland topography, differing in character according to local conditions. The shale in many places bears no vegetation and in the lowlands forms rounded domes ?ocally known as adobe hills. On the higher slopes, where erosion is more vigorous, the shale is cut by deep $V$-shaped ravines, the sides of which are steep or nearly vertical, as shown in Plate IV; $A$, page 22. These badlands are most conspicuous north of Delta. The outcrops of the principal coal beds are crossed by the main line of the Denver \& Rio Grande Railroad in Grand River valley and by a branch of the same road in the canyon of North Fork of Gunnison River. Railroad surveys have been extended east of Somerset in the canyon of the North Fork and in Coal Creek canyon to the prospect openings in the Coal Creek district; and also in Muddy Fork and in Anthracite Creek canyons to coal beds north of the area investigated, but no construction work has been done on these lines. A branch could easily be built to the coal in Minnesota Creek.

Two large rivers, the Grand and the Gunnison, draining the mountains on the east, flow through the Grand Mesa field. Aside from these rivers the drainage is of relatively small consequence. Heavy precipitation occurs in winter on Grand Mesa and in the mountains on the east, and the altitude is so high that the snow melts slowly and furnishes water during a large part of the summer. The water thus supplied by Grand Mesa will be of great importance in any development of the region around the mesa, as it is the only available supply. In the lowlands the rivers furnish an abundance of water, but the greater part of the coal, except in the Coal Creek district, is high in the sides of the mesa, and the water for domestic use in future mining camps and for such coal washeries as may be established will of necessity be derived from the melting snows on the mesa and conserved in storage reservoirs. The water of the streams above the line of the coal outcrop is clear and pure, but when it reaches the Mancos shale it becomes turbid and charged with noxious salts. In the Coal Creek district there is heavy precipitation on the surrounding highlands and excellent water is abundant. 
The heavy precipitation of the high altitudes, which is favorable for mining, since it supplies water and causes a heavy growth of timber, is unfavorable for determining accurately the location of the outcrops of coal beds. The moisture nourishes dense growths of brush, which cover considerable areas along the zone of the coalbearing rocks and render it impossible to follow individual coal beds continuously or even to determine the number of such beds except in a few places where landslides or washouts have occurred. The brush is especially troublesome in the Coal Creek district, where rainfall is abundant on account of the surrounding high mountains, and the problem of finding the outcrop of the coal is further complicated by the great quantities of fragmental rock derived from the mountain sides and by the downward creep of the surface rocks of the steep slopes.

\section{FLORESTA FIELD.}

The Floiesta field is notable for steep and densely wooded mountain slopes. (See Pl. XI, p. 140.) The Anthracite Range, on the north side of which the Floresta field lies, has a maximum elevation of 12,251 feet, and in it the tributaries of Anthracite Creek have eroded deep, narrow canyons. The coal crops out at altitudes of 10,000 feet or more, and the approach to it is difficult. However, a wagon road and a railroad have been built along the canyon sides to the mining town of Floresta, but the altitude is so great that the town is usually snowbound during the winter and early spring, and mining operations are interrupted during these seasons.

\section{MOUNT CARBON FIELD.}

The greater part of the Mount Carbon coal field lies within the Anthracite and Crested Butte quadrangles and its coal beds have been described in detail by G. H. Eldridge in Folio 9 of the Geologic Atlas of the United States. The approach to the coal from the valleys of Ohio and Carbon creeks, is easy, both by wagon road and railroad. In the southwest extension of the field west of Ohio Creek, the coal crops out in the.steep, rugged slopes of West Elk Peak, but the diffculties of approach can readily be overcome whenever the coal is wanted. Elsewhere throughout the field the slopes in the vicinity of the outcrop are gentle, and the surface is covered with vegetation so that in many places the beds can not be followed continuously. In the higher areas, particularly near Mount Wilkinson, the surface is densely wooded and the problem of locating the coal is still further complicated by the presence of considerable quantities of basalt débris from the cap of this mountain. However, prospecting in a commercial way is relatively easy in this field. The coal is not, deeply covered and is readily reached by shaft or drill. 


\section{CRESTED BUTTE FIELD.}

The Crested Butte field lies wholly within the Anthracite and Crested Butte quadrangles, which are described in detail in Geologic Folio No. 9, and the description of it need not be repeated here further than to point out the relation of the surface conditions to the development of the coal resources. The coal crops out in the steep slopes on either side of Slate River, the altitude of the beds ranging from 8,900 feet near Crested Butte to about 11;500 feet in Poyerty Gulch. In nearly all places along the line of outcrop of the coal beds the coal is overlain by a series of cliff-making sandstones, which attain a maximum thickness of about 1,500 feet. These sandstones usually form precipitous slopes, of which Scarp Ridge, Peeler Peak, and Schuylkill Mountain are conspicuous examples. The relation of these cliffs to the outcrops of the coal beds now covered by débris is well shown in Schuylkill Mountain, Plate XIII, $B$, page 170. Because of this heavy cover of débris, prospecting is difficult. The coal beds can not be followed continuously, for in some places along the line of outcrop there are long stretches where no coal was found, although the coal beds probably are continuous.

The economic development of the field has naturally followed the line of least resistance. The largest mine is at Crested Butte at a point near which the outcrops of the coal beds are almost at the level of Slate River, and the railway is built practically to the mouth of the mine. From this lowest point the beds rise in either direction along the outcrop and the other mines are connected with the railway by gravity inclines, the longest of which lowers the coal about 700 feet. As other mines are opened, longer inclines must be constructed, and development will become more and more difficult and expensive.

A railway is now in operation in Slate River valley through Crested Butte. An old extension no longer operated was built from Crested Butte to Anthracite, and this might easily be extended to Pittsburg. The grade in Oh-be-Joyful Gulch is probably not too steep for a railway; and doubtless a road will be built to the coal of this gulch.

\section{STRATIGRAPHY.}

\section{GENERAL STATEMENT.}

The geologic formations of the Grand Mesa and West Elk Mountain coal fields range from the red beds of Carboniferous (Pennsylvanian?) age to the Quaternary. The coal occurs about midway in this part of the geologic column, and as it was the principal subject of investigation little attention was given to either the oldest or the youngest formations. Relatively little has been published heretofore on the 40642 - Bull. 510-12-2 
geoology of this region. It was mapped and briefly described by the geologists of the Hayden Survey and a small part of it, covered by the Anthracite and Crested Butte quadrangles, was described in detail later by Eldridge in Folio 9 of the Geologic Atlas of the United States. The geologic formations occurring within these quadrangles were mapped and described with considerable care, and the mapping has been transferred without material change, except in the names and correlations of some of the formations, to the map accompanying this bulletin. For the descriptions the reader is referred to the Anthracite-Crested Butte folio. Detailed examinations were made in the coal-bearing zone, resulting in certain changes from the folio map and in the addition of many details arising from mining development since the publication of the folio. For reasons given on the following pages the geologic section published in Folio 9 has been changed and the Wasatch ("Ruby"). and Ohio Creek formations are placed in the Tertiary. The coal-bearing rocks are now referred, with some doubt, to the Mesaverde, and the marine shales between the Dakota and the Mesaverde are referred to the Mancos. A generalized section showing the succession, character, and relations of the formations that will be described is given in the accompanying table.

Generalized section of sedimentary formations in the Grand Mesa and West Elk Mountain coal fields, Colorado.

\begin{tabular}{|c|c|c|c|c|c|c|}
\hline System. & Group. & Formation. & Member. & $\begin{array}{l}\text { Thick- } \\
\text { ness. }\end{array}$ & Characteristics. & $\begin{array}{l}\text { Economic } \\
\text { value. }\end{array}$ \\
\hline $\begin{array}{l}\text { Quater- } \\
\text { nary. }\end{array}$ & & & & Feet. & River gravels. & \\
\hline \multirow{3}{*}{$\begin{array}{l}\text { Tertiary } \\
\text { (Eocene } \\
\text { series). }\end{array}$} & & $\begin{array}{l}\text { Green River } \\
\text { formation. }\end{array}$ & & $\begin{array}{r}200- \\
1,800\end{array}$ & $\begin{array}{l}\text { White friable sandstone and } \\
\text { clay shale capped by basalt. }\end{array}$ & \\
\hline & & \multirow{2}{*}{$\begin{array}{l}\text { W as atch } \\
\text { ("Ruby") } \\
\text { formation. } \\
\\
\text { Unconform- } \\
\text { ity. } \\
\text { Ohio Creek } \\
\text { con glom- } \\
\text { erate. } \\
\text { Unconform- } \\
\text { ity. }\end{array}$} & & $\begin{array}{r}500- \\
2,500\end{array}$ & $\begin{array}{l}\text { Conglomeratic sandstone and } \\
\text { shale, varicolored; also tuff } \\
\text { of andesitic material. In } \\
\text { the eastern part of the fleld } \\
\text { the rocks are mostly red } \\
\text { and conglomeratic beds are } \\
\text { numerous. The basal con- } \\
\text { glomerate consists princi- } \\
\text { pally of quartz and chert } \\
\text { pebbles and the higher } \\
\text { ones of various crystalline, } \\
\text { metamorphic, and extru- } \\
\text { sive rocks. In the western } \\
\text { part of the field, lighter } \\
\text { colors prevail, and the rocks } \\
\text { are finer in texture. }\end{array}$ & \\
\hline & . & & . & $100-200$ & $\begin{array}{l}\text { White friable conglomeratic } \\
\text { sandstone containing peb- } \\
\text { bles of quartz, jasper, and } \\
\text { igneous rock. }\end{array}$ & \\
\hline
\end{tabular}


Generalized section of sedimentary formations in the Grand Mesa and West Elk Mountain coal fields, Colorado-Continued.

\begin{tabular}{|c|c|c|c|c|c|c|}
\hline System. & Group. & Formation. & Member. & $\begin{array}{l}\text { Thick- } \\
\text { ness. }\end{array}$ & Characteristics. & $\begin{array}{l}\text { Economic } \\
\text { value. }\end{array}$ \\
\hline \multirow{6}{*}{$\begin{array}{l}\text { Creta- } \\
\text { ceous } \\
\text { (Upper } \\
\text { Creta- } \\
\text { ceous } \\
\text { series). }\end{array}$} & \multirow{5}{*}{$\begin{array}{c}\text { Mo n- } \\
\text { tana. }\end{array}$} & \multirow{4}{*}{$\begin{array}{l}\text { M e s averde } \\
\text { formation. }\end{array}$} & . & $\begin{array}{l}\text { Feet. } \\
2,000 \pm\end{array}$ & $\begin{array}{l}\text { Gray quartzose sandstone } \\
\text { ranging from soft and fri- } \\
\text { able to hard and cliff-mak- } \\
\text { ing, and shale with plant } \\
\text { remains and shells of fresh- } \\
\text { water invertebrates. (Pre- } \\
\text { viously called Laramie. } \\
\text { May prove to be Laramie } \\
\text { or younger.) }\end{array}$ & $\begin{array}{l}\text { Coal of doubt- } \\
\text { ful value } \\
\text { near the cen- } \\
\text { ter of the sec- } \\
\text { tion in the } \\
\text { eastern part } \\
\text { of the Grand } \\
\text { Mesa field. }\end{array}$ \\
\hline & & & \multirow{2}{*}{$\begin{array}{l}\text { Paonia shale. } \\
\text { Unconform- } \\
\text { ity. }\end{array}$} & $400+$ & $\begin{array}{l}\text { Shale, carbonaceous in places, } \\
\text { and sandstone, with plant } \\
\text { remains and shells princi- } \\
\text { pally of fresh-water inver- } \\
\text { t e b a tes. (Prevlously } \\
\text { called Laramie. May prove } \\
\text { to be Laramie or younger.) }\end{array}$ & $\begin{array}{l}\text { Coal bearing } \\
\text { th roughout; } \\
\text { coal ranging } \\
\text { from subbl- } \\
\text { tuminous to } \\
\text { anthracite. }\end{array}$ \\
\hline & & & & $0-425$ & $\begin{array}{l}\text { Dark-colored shale and gray } \\
\text { sandstone containing ma- } \\
\text { rine and brackish-water in- } \\
\text { vertebrates. (Absent from } \\
\text { central part of Grand Mesa } \\
\text { fleld and from Crested } \\
\text { Butte field.) }\end{array}$ & $\begin{array}{l}\text { Coal bearing } \\
t \mathrm{~h} \text { roughout; } \\
\text { coal ranging } \\
\text { in quality } \\
\text { from bitum- } \\
\text { inous to an- } \\
\text { thracite. }\end{array}$ \\
\hline & & & $\begin{array}{l}\text { Rollins } \\
\text { sandstone. }\end{array}$ & $100 \pm$ & $\begin{array}{l}\text { White cliff-making sandstone } \\
\text { containing fucoids and ma- } \\
\text { rine invertebrates. }\end{array}$ & \\
\hline & & $\begin{array}{l}\text { M a n c o s } \\
\text { shale. }\end{array}$ & & $3,000 \pm$ & $\begin{array}{l}\text { Dark-colored shale with } \\
\text { limestone concretions and } \\
\text { m a rine in v e rtebrates. } \\
\text { Sandy limestone occurs lo- } \\
\text { cally near the top, and the } \\
\text { base consists of black car- } \\
\text { bonaceous coal-bearing } \\
\text { shale and flinty sandstone. } \\
\text { The upper portion is corre- } \\
\text { lated on fossil evidence } \\
\text { with part of the Pierre } \\
\text { shale and the lower portion } \\
\text { with the Benton. }\end{array}$ & $\begin{array}{l}\text { Coal of poor } \\
\text { quality in } \\
\text { thin irregu- } \\
\text { lar beds at } \\
\text { the base. }\end{array}$ \\
\hline & & $\begin{array}{l}\text { D a k o t a } \\
\text { sandstone. }\end{array}$ & & $10-100+$ & Conglomeratic sandstone. & \\
\hline $\begin{array}{l}\text { Jurassic } \\
\text { (?). }\end{array}$ & . & $\begin{array}{l}\text { G un n i son } \\
\text { formation. } \\
\text { Unconform- }\end{array}$ & & $600+$ & $\begin{array}{l}\text { Variegated shale and sand- } \\
\text { stone ranging from fine- } \\
\text { grained and flinty to } \\
\text { coarse-grained, conglomer- } \\
\text { atic and friable. Colored in } \\
\text { various shades of red, yel- } \\
\text { low, green, blue, etc. Some } \\
\text { limestone beds in lower } \\
\text { part. }\end{array}$ & . \\
\hline $\begin{array}{l}\text { C a rbon- } \\
\text { iferous } \\
(?)\end{array}$ & & $\begin{array}{l}\text { ity (?). } \\
\text { Maroon con- } \\
\text { glomerate } \\
\text { Pennsyl- } \\
\text { vanian (?) } \\
\text { age), east } \\
\text { of Crested } \\
\text { B u t } t \text { e. } \\
\text { Red beds } \\
\text { of u n - } \\
\text { k n o w n } \\
\text { ag e in } \\
\text { G r a n d } \\
\text { Mesa field. } \\
\text {. }\end{array}$ & . & $4,500 \pm$ & $\begin{array}{l}\text { Massive red sandstone and } \\
\text { conglomerate. }\end{array}$ & - \\
\hline
\end{tabular}


The relations of the formational units recognized in this report to those recognized by earlier writers in this region are shown in the following table:

Table showing relations of formations.

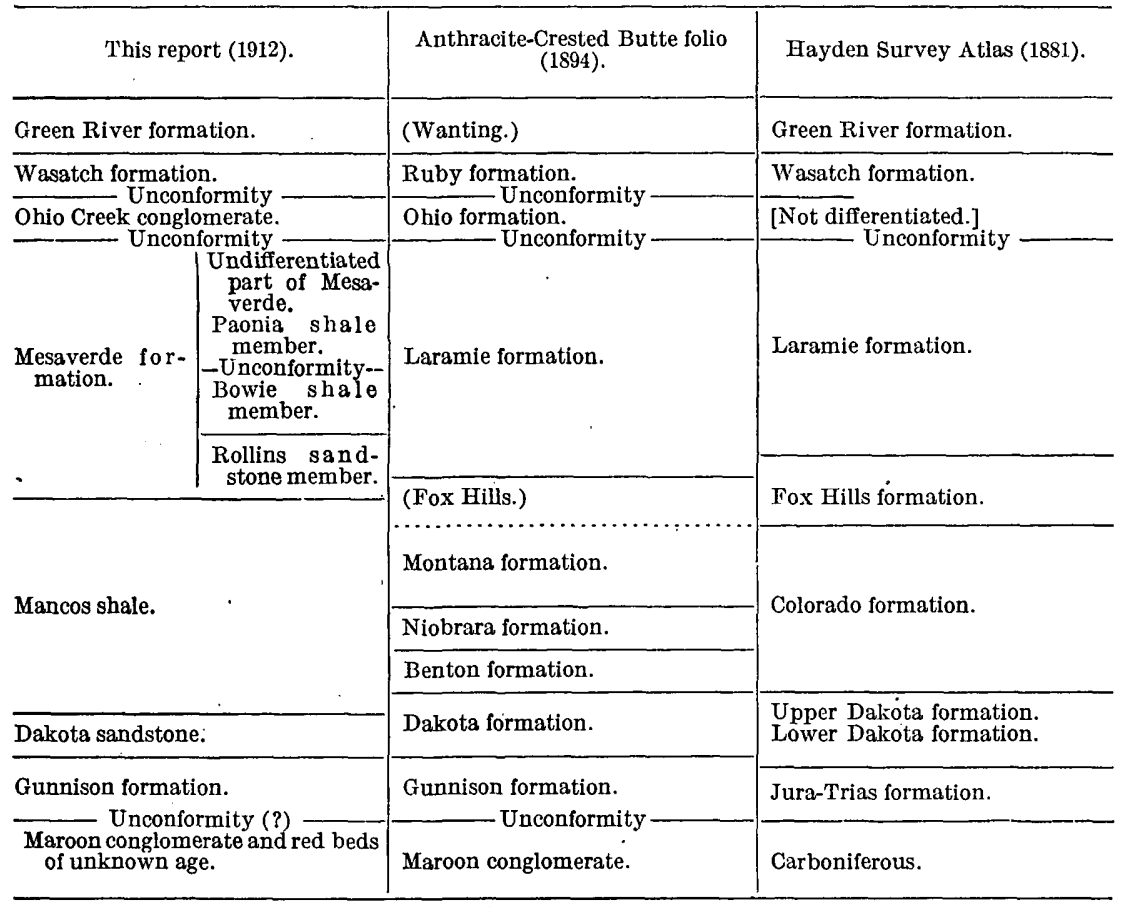

The unconformity at the top of the Bowie shale has not been demonstrated outside of the Grand Mesa field and its significance can not be stated without further investigation. The section essentially as it stands was adopted for the preliminary report on the Grand Mesa field, published in 1909. More recent information regarding the fossil plants renders doubtful the reference of the Paonia shale and the overlying unnamed beds to the Mesaverde, as will be shown in the following discussion. However, since the new data are not full enough to be convincing the section is allowed to stand until conclusive evidence is obtained.

\section{CARBONIFEROUS SYSTEM.}

\section{PENNSYLVANIAN (?) SERIES ("RED BEDS").}

\section{MAROON CONGLOMERATE.}

The Maroon conglomerate, which outcrops north and east of Crested Butte, is of Carboniferous age, according to Eldridge, and is believed by Girty to belong probably to the Pennsylvanian series. It does not outcrop within the area included in the accompanying map and was not examined during the investigation but is extensively developed a few miles farther east and probably underlies the 
rocks at the east end of the area here described. It lies unconformably beneath the Gunnison formation in the Crested Butte region, where no beds of Permian or Triassic age are known to occur. In the Grand Mesa field near the west end of the area described, red sandstone underlies the Gunnison formation, but little attention was given to it and no evidence of its age was obtained. It occurs at the base of the cliffs along the Gunnison River and occupies an extensive area farther south. It is apparently unconformable with the Gunnison formation and was described by the geologists of the Hayden Survey as Triassic.

\section{JURASSIC (?) SYSTEM.}

\section{GUNNISON FORMATION.}

The Gunnison formation is the oldest one shown on the accompanying map. It includes the variegated sandstone and shale between the underlying red beds and the Cretaceous rocks. The lower limit of the "Jurassic" as defined by Peale ${ }^{1}$ is here used as the line of separation between the red beds and the Gunnison formation. The upper limit of the Gunnison is marked by an erosional unconformity between the variegated shale and the overlying Dakota sandstone. As thus defined the Gunnison formation has a maximum thickness of 682 feet. It consists of two members which are more or less distinct lithologically but perfectly conformable so far as observed and apparently the result of continuous deposition. The lower member represented by numbers $9-17$ in section 6 , figure 3 (p. 50), contains some limestone but consists principally of evenbedded flaggy sandstone, as shown at the base of the cliff marked $a$ in Plate IV $B$. It is apparently this lower member which includes less than half of the variegated beds, that Peale ${ }^{1}$ describes as Jurassic. Riggs ${ }^{2}$ refers it to the marine Jurassic, although he presents no evidence of its marine character. The writer found no fossils in these beds and their provisional reference to the Jurassic is based on their resemblance to fossil-bearing beds elsewhere.

The upper member of the Gunnison formation is shown in Plate IV, $B$, as the smooth shale slope marked $b$ above the flaggy sandstones and consists principally of variegated shale with a coarse conglomeratic sandstone (No. 5 of section 6, fig. 3, p. 50) near the top. The highly colored shale constituting the principal part of this upper member is apparently included in the "variegated beds," mapped in the Atlas of Colorado, and the jasper-bearing sandstone (No. 5) in the upper part apparently forms a part of the "Lower Dakota" of Peale. ${ }^{3}$ The variegated color of the Gunnison formation

\footnotetext{
1 Peale, A. C., Tenth Ann. Rept. U. S. Geol. and Geog. Survey Terr., 1876, p. 179.

2 Riggs, Elmer S., Dinosaur beds of Grand River valley, Colo.: Pubs. Field Columbian Mus., vol. 1, 1901 , p. 269.

3 Op. cit., pp. 180-181.
} 
is considered as diagnostic of the formation, and this character prevails through the jasper-bearing conglomerate up to the unconformity at the top of No. 5 of the following section. For this reason the line of separation between the Gunnison and the Dakota is drawn at this unconformity.

Section of rocks exposed in Gunnison Canyon at the mouth of Wells Gulch.

[For graphic section see fig. 3, No. 6, p. 50.]

Feet.

1. Sandstone in thin flinty layers separated by dark-colored shale. 20

2. Coal....................................... 3

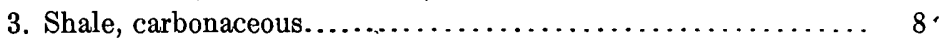

4. Conglomerate, quartzitic, gray to buff (Dakota)............ 15

Unconformity by erosion.

5. Sandstone, conglomeratic, with beds of variegated shale. The conglomerate contains many pebbles of quartz and jàsper.... 100

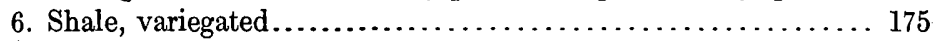

7. Sandstone, white, argillaceous....................... 5

8. Shale, soft, variegated, contains pockets filled with pebbles of jasper, chert, argillite, etc., also globular and lenticular bodies of pink to red calcite, having a maximum diameter of 5 feet.. 200

9. Sandstone, gray, coarse grained, cross bedded............. 50

10. Sandstone, brown, massive........................... 8

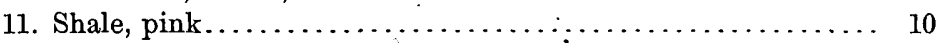

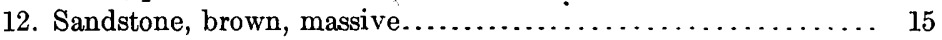

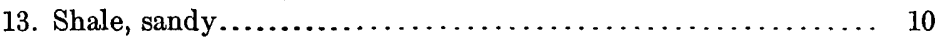

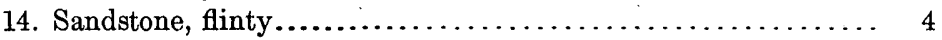

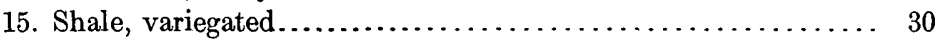

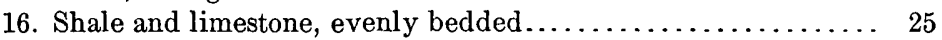

17. Shale and sandstone in thin regularly bedded layers........ 50 Unconformity by erosion.

18. Sandstone (red beds).

Total.

The only fossils that were found in the variegated shale in the Grand Mesa field are a few poorly preserved specimens of Unios (see No. 10 of section on p. 24), which occur in a friable sandstone near the top of the Gunnison formation. However, Riggs ${ }^{1}$ found near Grand Junction in the upper part of this formation a species of Viviparus and reptilian remains that prove the beds containing them to be equivalent in age to the Morrison formation of the eastern Rocky Mountains. Siebenthal ${ }^{2}$ examined this formation east of Delta and observed that it was divisible into a lower member, composed of flaggy beds containing limestone from which he collected fresh water fossils, and an upper member, composed of variegated shale. The lower member of Siebenthal is apparently identical with the flaggy beds of the lower third of the section given above (fig. 3, section No. 6, p. 50). Eldridge ${ }^{3}$ also describes a limestone in the lowest

\footnotetext{
1 Riggs, E. S., op. cit., p. 272.

2 Siebenthal, C. E., Gypsum of the Uncompahgre region, Colo.: Bull. U. S. Geol. Survey No. 285, 1906, p. 402.

8 Eldridge, G. H., Anthracite-Crested Butte folio (No. 9), Geol. Atlas U. S., U. S. Geol. Survey, 1894.
} 


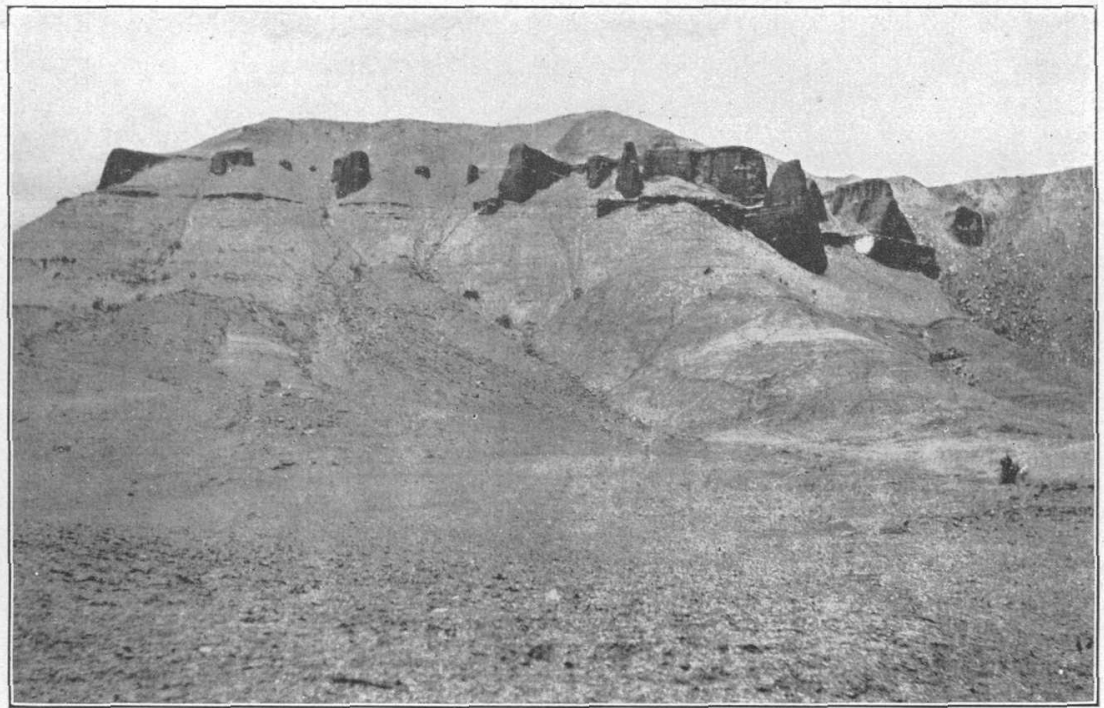

d. HILL CONSISTING OF MANCOS SHALE NEAR DELTA, COLO.

Illustrating the barrenness of the shale slopes, and showing the occurrence of a zone of black shale about 300 feet above the base of the formation.

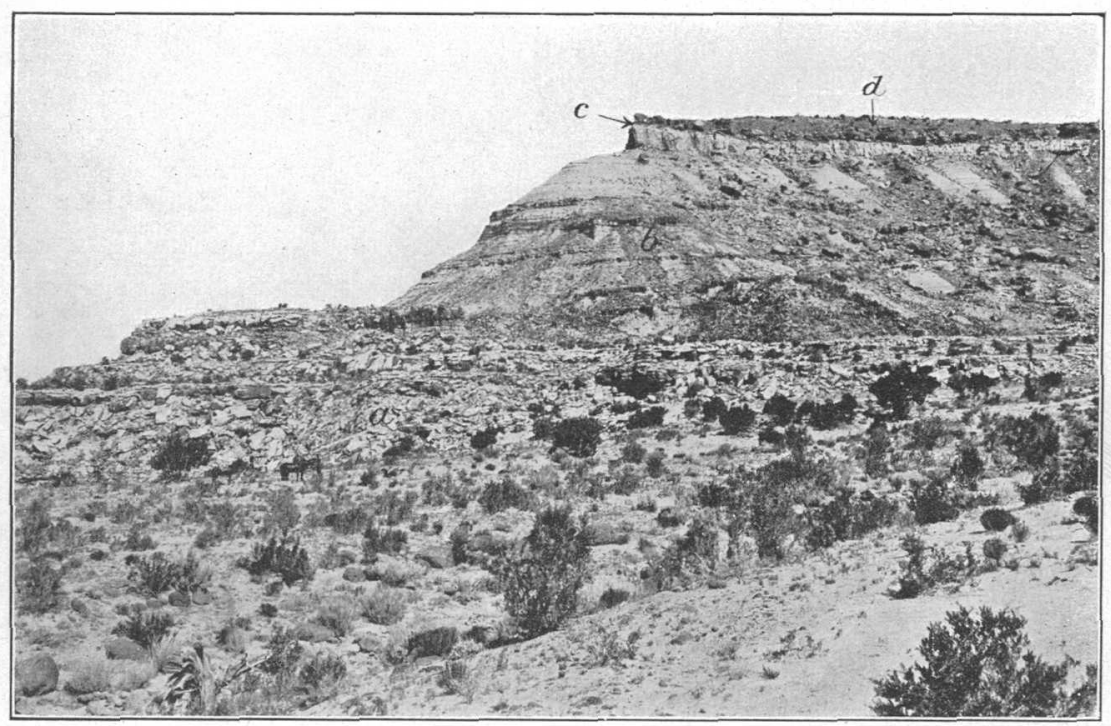

B. NORTH WALL OF GUNNISON CANYON AT MOUTH OF WELLS GULCH.

Showing the lower or flaggy member of the Gunnison formation $(a)$, overlain by variegated shale $(b)$, and the unconformity $(c)$ and conglomerate $(d)$ at the base of the Dakota sandstone. 
part of the Gunnison formation in the Crested Butte region, which contains fresh-water shells of the genera Limnea, Valvata, and Cypris, and says that "The assignment of this formation to late Juratrias age -is based upon the stratigraphic and lithologic correspondence with the Atlantasaurus beds (Morrison) on the eastern flanks of the Rocky Mountains and upon the similarity of its molluscan fauna to that of these beds." The localities described by Eldridge in the Crested Butte region and those of the Gunnison Canyon are less than 100 miles apart and the beds, although deeply buried beneath younger rocks between these localities, show little difference in lithologic character. The occurrence of reptilian remains of Morrison age near Grand Junction confirms the correlation that Eldridge made on the basis of lithology and the molluscan fauna.

\section{CRETACEOUS SYSTEM.}

\section{DAKOTA SANDSTONE.}

The beds here referred with doubt to the Dakota consist of massive gray conglomerate and conglomeratic sandstone and lie unconformably upon the variegated beds of the Gunnison formation and conformably beneath the coal-bearing rocks at the base of the Mancos shale. They range in thickness from 10 to 100 feet and in some places contain poorly preserved leaves of dicotyledonous plants. However, no fossil leaves were obtained that could be specifically identified, and the formation is referred to the Dakota on lithologic and stratigraphic evidence. The sandstone grades upward into the overlying shale of Benton age through transitional beds that consist of alternate layers of sandstone, carbonaceous shale, and coal. For this reason it is uncertain whether the coal that occurs in this transition zone should be referred to the Dakota or to the Mancos. It is locally called the Dakota coal, but for reasons stated below it is here included in the Mancos shale. Its relations are shown in the following section:

Section of rocks exposed in Gunnison Canyon at the mouth of Kahnah Creek.

[For graphic section see fig. 3, No. 5, p. 50.]

1. Shale (Mancos) containing 50 feet above the base shells of the invertebrates Ostrea lugubris Conrad, Inoceramus fragilis H. and M., and Inoceramus dimidius White ..............

2. Sandstone, flinty, cross-bedded, ripple-marked..............

3. Shale ........................................... 10

4. Sandstone, cross-bedded, conglomeratic in some places...... 15

5. Shale, carbonaceous, coal-bearing................... 4

6. Conglomerate (Dakota), with pebbles of quartzite, argillite, chert, etc., contains fossil leaves and fragments of petrified

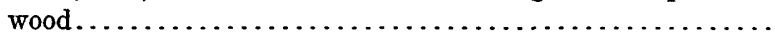

Unconformity by erosion.

Top of Gunnison formation.

Feet. 
7. Feet.

7. Sandstone, coarse, cross-bedded, weathering to a mottled red. 15

8. Shale, red, green, blue, yellow, etc................... 20

.9. Sandstone, coarse, cross-bedded, massive; contains worm

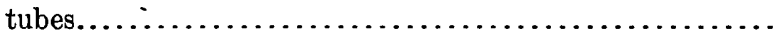

10. Sandstone, conglomeratic; pebbles of argillite, quartz, jasper, etc., containing Unio sp......................... 1

11. Shale, sandy, brick red.......................... 5

12. Sandstone, massive, conglomeratic................... 25

13. Shale, not well exposed.......................... $\quad 50$

Total................................... 190

The formations were not examined in detail near Gunnison River east of Delta, but through the courtesy of C. E. Siebenthal, who has examined this region but whose report is not yet published, the occurrence of the Dakota in that region is shown on the accompanying map. Siebenthal draws the line of contact between the Dakota and the overlying Mancos shale at the top of the flinty sandstones and above the coal. This line was used also by the geologists of the Hayden Survey to denote the upper limit of the Dakota, but for the reasons stated in the following section the line marking the top of the Dakota is here drawn below the coal, thus making the Dakota at the mouth of the Black Canyon of the Gunnison not more than 100 feet thick. instead of 200 feet as stated by Siebenthal. ${ }^{1}$

The Dakota in the Crested Butte field was not examined by the writer. Eldridge states in Folio 9 that it consists of-

white quartzitic sandstone with a fine-grained conglomerate at the base formed of very well rounded pebbles of the most dense and resisting siliceous material, generally light or dark chert and jasper. As a rule it carries abundant dicotyledonous plant remains but no other forms of life. * * * It varies in thickness from 50 to 300 feet. The white quartzite generally occurs in one or two benches with seams of clay near the middle. The conglomerate at the base of the quartzite is usually 2 to 5 feet thick. A second fine-grained conglomerate, whose pebbles are variously colored cherts and jaspers, occurs below this separated from the quartzite by a stratum, sometimes 50 feet thick, of greenish clays resembling those of the Gunnison formation, to which they may belong. Toward the top the Dakota quartzite becomes shaly and alternates in thin layers with the dark sediments of the Benton formation.

The part of Eldridge's section referred to the. Dakota apparently includes the conglomerate, which is probably equivalent to the jasper-bearing conglomerate that in the Grand Mesa field is included by the present writer in the Gunnison formation and is separated by an unconformity from the conglomerate that the present writer refers to the Dakota. Eldridge's Dakota also includes the transition beds at the base of his Benton [Mancos shale], which; although they contain no coal, apparently correspond to the rocks of the coalbearing transition zone in the Grand Mesa field, which is here included in the Mancos.

1 Siebenthal, C. E., Gypsum of the Uncompahgre region, Colorado: Bull. U. S. Geol. Survey No. 285, 1906, p. 402. 
The shale that occurs above the Dakota in the Grand Mesa field and outcrops in the lower slopes of Grand Mesa is about 3,000 feet thick. This estimate is obtained by adding the correction for dip to the difference in altitude between the base and top of the shale at the exposures east of Grand Junction. As thus defined for the Grand Mesa field, the Mancos shale includes all rocks of Colorado and lower Montana age lying between the Dakota sandstone and the Rollins sandstone member of the Mesaverde formation. At the top is included the transitional zone to the Rollins sandstone, which was referred by the Hayden geologists to the Fox Hills.

The formation consists almost wholly of dark to buff shale, which varies little in physical character from place to place. At the base the shale is carbonaceous and contains beds of coal and thin layers of flinty sandstone. Near the top there are lenticular masses of yellow sandy limestone, but although the base is known on fossil evidence to be of Benton age and the top to be of Pierre age, the formation is a lithologic unit. The upper part near the Mesaverde coal and the lower part containing the coal beds near the Dakota sandstone were examined in detail, but little attention was given to the middle portion.

The flinty sandstones form the surface of the dip-slopes north of Gunnison River, and they together with the coal-bearing shale associated with them have heretofore been included in the Dakota. However, in these sandstones above the coal the writer found Inoceramus labiatus Schlotheim (see bed No. 3 in section on p. 68), a well-known Benton fossil, and Peale ${ }^{1}$ states that a scaphite was found below the coal near the mouth of Gunnison River. In the light of this fossil evidence, the line marking the base of the Mancos shale can not be drawn at the top of the sandstone where previously it has been drawn, and there is no natural line of division within the transitional zone of sandstone and carbonaceous shale. Apparently the only rational place to draw the line of separation between the Dakota and the Mancos is at the top of the massive conglomeratic sandstone, thereby placing the coal beds in the Mancos shale. This reference of the coal to the lower part (Benton age) of the Mancos finds support in the occurrence of coal of Benton age in Green River valley near Vernal, Utah, ${ }^{2}$ and at Coalville and elsewhere in Utah. ${ }^{3}$

About 100 feet above the base of the shale, there is a zone of concretions and lenticular bodies, some of them 10 feet or more in

\footnotetext{
1 Peale, A. C., Eighth Ann. Rept. U. S. Geol. and Geog. Survey Terr., 1876, p. 135.

2 Gale, H. S., Coal fields of northwestern Colorado and northeastern Utah; Bull. U. S. Geol. Survey No. 341, 1909, p. 308.

${ }^{s}$ Stanton, T. W., The Colorado formation and its invertebrate fauna: Bull. U. S. Geol. Survey No. 106, 1893, pp. 34-46.
} 
diameter, composed of brittle yellow earthy limestone containing such Benton forms as Ostrea lugubris Conrad, Inoceramus fragilis H. and M., and Inoceramus dimidius White: For a distance of 50 to 100 feet above the zone of concretions the shale is more or less carbonaceous and fissile, cleaving in paper-like flakes. In some places it is black and forms high bluffs (see Pl. IV, $A$, p. 22), although both the overlying and underlying shale break down readily, forming smooth slopes.

The central part of the Mancos consists of buff shale which weathers into rounded barren hills in the lowlands and into badlands in the steep slopes of the mesa. It is very fossiliferous in places and large Inoceramus shells are especially abundant, but no collections of fossils were made.

The greater part of the time devoted to field investigation in the Grand Mesa field was spent in studying the coal-bearing rocks that occur above the Mancos shale; the upper part of this shale near the coal was also observed closely, and fossils were collected from it in many places. In some places the change from the shale to the overlying Rollins sandstone is abrupt, and the line of separation between the Mancos and the Mesaverde can be definitely fixed. In other places the transition takes place through a series of sandy layers separated by shale, but in every case, for purposes of this report, the top of the Mancos is drawn at the base of the massive Rollins sandstone. Lenticular masses of yellow sandy limestone occur near the top of the shale and contain great quantities of fossil shells. The largest lens observed lies east of the Rollins mine and is about 100 feet thick and several miles long. Nearly all of the fossils collected from the Mancos shale, were found in the limestone lenses. By means of these fossils, together with those collected from the base of the formation, the shale is correlated with the Mancos shale of southwestern Colorado as named and described by Cross. ${ }^{1}$ The lithologic character as well as the organic remains agree closely with those of the shale in its type locality, Mancos Valley, in southwestern Colorado, and the name is retained on the assumption that the shale in the Grand Mesa and West Elk Mountain coal fields and that in Mancos Valley are parts of a once continuous formation.

Fossils were collected from the Mancos shale at many localities in the Grand Mesa field, but they are better preserved in some places than in others. Six localities, at which the best collections were made, are indicated on the accompanying map and are named below in connection with the lists of fossils collected at the several places. The horizons at which the fossils occur are also given. The numerals denoting these localities on the map and in the following descrip-

1 Cross, Whitman, Telluride folio (No. 57), Geol. Atlas U. S., U. S. Geol. Survey, 1899. 
tions refer to the Mesozoic fossil locality records of the United States Geological Survey.

No. 4206. Location, 9 miles northwest of Delta, Colo., near the top of the Mancos shale.

Avicula nebrascana E. and S.

Inoceramus barabini Morton.

Syncyclonema rigida $\mathrm{H}$. and $M$.

Nucula sp.

Leda sp.

Lucina subundata $\mathrm{H}$. and $\mathrm{M}$.

Cardium speciosum M. and $\mathrm{H}$.

Thetis circularis M. and $\mathrm{H}$.

Tellina sp.

Dentalium sp.

Volutoderma sp.

Heteroceras sp.

No. 4216. Location, 10 miles north of Delta, Colo., about 200 feet below the top of the Mancos shale.

Ostrea sp.

Inoceramus barabini Morton.

Inoceramus sagensis Owen.

Inoceramus sp.
Avicula nebrascana E. and S.

Anisomyon shumardi M. and H.?

Baculites ovatus Say.

Scaphites nodosus Owen.

Nos. 4209 and 4208. Location, 12 miles north of Delta, Colo., 100 to 300 feet below the top of the Mancos shale.

Ostrea sp.

Avicula nebrascana E. and S. Avicula linguiformis $\mathrm{E}$. and $\mathrm{S}$.

Inoceramus barabini Morton.
Inoceramus sagensis Owen. Scaphites nodosus Owen. Placenticeras whitfieldi Hyatt.

The specimen of Inoceramus sagensis shown in Plate XV, figure 3, was collected at this locality.

No. 4217. Location, 12 miles northeast of Delta, Colo., about 400 feet below the top of the Mancos shale.

Serpula sp.

Ostrea sp.

Inoceramus sagensis Owen.

Inoceramus barabini Morton.
Inoceramus sp.

Avicula nebrascana E. and S.

Anatina sp.

Placenticeras intercalare M. and $H$.

The specimen of Inoceramus barabini shown in Plate XV, figure 1, was collected at this locality.

No. 4490. Location, Minnesota Creek 7 miles east of Paonia, Colo., near the top of the Mancos shale.

Ostrea sp.

Avicula linguiformis $\mathbf{E}$. and $\mathrm{S}$.

Cardium speciosum $M$. and $\mathrm{H}$.

Mactra formosa $M$. and $\mathrm{H}$.

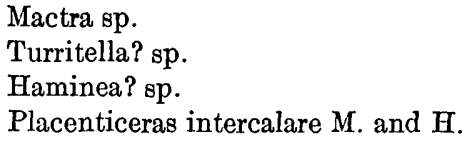

The specimen of Mactra formosa shown in Plate XV, figure 2, and the specimens of Cardium speciosum shown in Plate XVI, figures 1 and 2, were collected at this locality.

No. 4502. Location, Minnesota Creek 9 miles southeast of Paonia, Colo., at the top of the Mancos shale.

Ostrea sp.

Leda sp.

Cardium speciosum M. and $\mathrm{H}$.
Mactra sp. 
The following list inoludes all forms collected from the upper part of the Mancos shale, including the separate lists just described. The species all belong to the fauna of the Montana group.

\section{Fossils from the upper part of the Mancos shale, in the Grand Mesa field.}

[Identified by T. W. Stanton.]

Serpula sp.

Ostrea sp.

Avicula nebrascana E. and S. Avicula linguiformis $\mathrm{E}$. and S. Inoceramus barabini Morton. Inoceramus sagensis Owen. Inoceramus sp.

Syncyclonema rigida $\mathrm{H}$. and M. Nucula sp.

Leda sp.

Lucina subundata $\mathrm{H}$. and $\mathrm{M}$. Cardium, speciosum M. and H. Cardium sp.

Thetis circularis $M$. and $H$.

Callista? sp.

Tellina sp.

Mactra formosa M. and $\mathrm{H}$. Mactra warrenana M. and $\mathrm{H}$.

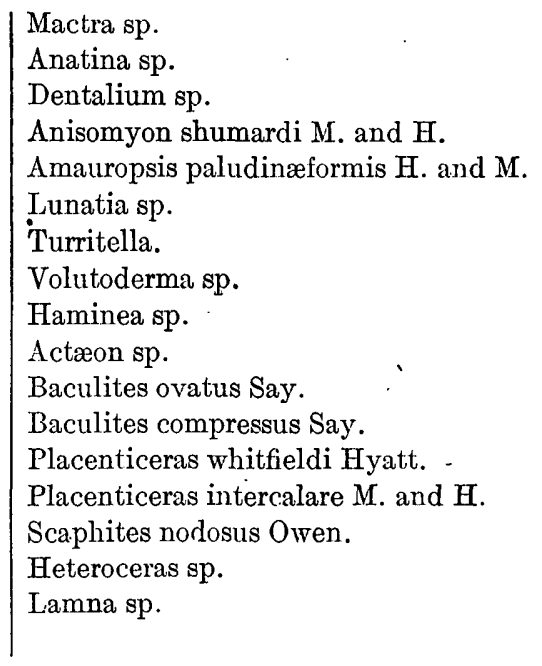

The Mancos shale disappears east of Coal Creek beneath a cover of younger rocks about 10 miles wide and reappears at the surface farther east with little change in character. It is the shale that constitutes the principal part of the "Montana" of Eldridge's section and that he correlates with the Pierre. Only the upper part of this shale was examined by the present writer, but Eldridge described it as fossiliferous, the most common mollusks being Inoceramus barabini, Inoceramus sagensis, Placenticeras placenta, Baculites, and Scaphites. Below this upper part of the shale, according to Eldridge, occurs 20 to 40 feet of Niobrara limestone, containing Ostrea congesta and Inoceramus deformis, overlain by 80 to 160 feet of shale, and 150 to 300 feet of dark-colored shale containing Inoceramus problematicus and Scaphites warreni occurs between his Niobrara limestone and Dakota sandstone. Eldridge maps the Niobrara and Benton as separate formations. These lower beds were not examined by the present writer.

The upper part of Eldridge's Montana, his so-called Fox Hills division, contains Mactra holmesii, Cardium speciosum, and Nucula and is the transitional zone from the Mancos shale to the Rollins sandstone described in this report. 


\section{MESAVERDE FORMATION.}

GENERAL STATEMENT.

Mesaverde is a name originally given by Holmes ${ }^{1}$ to the coalbearing formation about midway of the Cretaceous section of southwestern Colorado. It is there separated from the coal-bearing Laramie (?) formation by the Lewis shale.

In northwestern Colorado, north of the area described in this bulletin, Fenneman, ${ }^{2}$ Gale, and others following them have shown that there are two coal-bearing formations which they correlate, largely on stratigraphic evidence, with the Mesaverde and the Laramie (?) of southwestern Colorado. The two coal-bearing formations are separated by a marine shale, which is correlated with the Lewis. The Grand Mesa field lies midway between these two localities, and the Mesaverde formation of northern Colorado has been traced southward practically to the coal fields of Grand Mesa and the West Elk Mountains, so that at least a part of the coal-bearing rocks of these fields are certainly equivalent to the Mesaverde. The invertebrate fossils collected in the Grand Mesa field are thought to bear out this correlation, although it is confessedly difficult in the present state of knowledge to distinguish between Mesaverde and Laramie fossils. (See p. 43.) On the assumption that the unconformity between the Bowie and Paonia members of the Mesaverde (to be described later) is local, the coal-bearing rocks of the Grand Mesa and West Elk Mountains fields, previously called Laramie, have all been referred provisionally to the Mesaverde, although the fossil plants above the unconformity seem to indicate a later age. It is possible that this unconformity will be found on further investigation to represent the time interval between the Mesaverde and the Laramie, and that the plant-bearing beds above the unconformity will yet prove to be of Laramie age, as stated by Eldridge in his description of the Anthracite-Crested Butte region or even still younger, as suggested by a study of the plants. (See pp. 45-47.)

The Mesaverde formation is 600 to 2,500 feet thick in the West Elk Mountain region, an unknown thickness having been eroded from the top before the deposition of the next younger formations. It includes all of the sedimentary rocks in this region that intervene between the top of the Mancos shale and the overlying 'Tertiary beds. So far as known there is no representative of the Lewis shale, and the Tertiary conglomerates rest unconformably upon the sandstones of the Mesaverde. The geologists of the Hayden Survey describe the,

\footnotetext{
1 Holmes, W. H., Ninth Ann. Rept. U. S. Geol. and Geog. Survey Terr., 1875, pl. 35, opp. p. 244.

2 Fenneman, N. M., and Gale, H. S., The Yampa coal field, Routt County, Colo.: Bull. U. S. Geol. Survey No. 297, 1906. See also Gale, H. S., Geology of the Rangely oil district, Rio Blanco County, Colo.: Bull. U. S. Geol. Survey No. 350, 1908, p. 27.
} 
lower part of this formation as Fox Hills and the upper part of it as Laramie. Hills, ${ }^{1}$ Eldridge, ${ }^{2}$ and others refer all of the coal-bearing rocks to the Laramie, and this disposition of them has been widely accepted. However, the invertebrate fossils named in the following pages are regarded by the paleontologists as furnishing sufficient evidence for referring the formation to the Mesaverde.

The Mesaverde of the Grand Mesa and West Elk Mountain region differs considerably in physical character from the Mesaverde as described from other fields. Among the most notable of these differences may be mentioned the arenaceous character of the upper beds, the grouping of the coal near the base, the separation by a line of unconformity of the coal-bearing rocks into a lower marine and brackish water member and an upper nonmarine member, and the absence generally of rocks of brackish water origin above the unconformity. At one locality near Palisades (see p. 78) shells of brackish-water origin were found above the lowest coal bed of the upper or "nonmarine" member, and in a few other places shells of the species Corbula subtrigonalis supposed to be of brackish-water habitat were found associated with fresh-water shells.

Since the Mesaverde contains all of the coal of commercial importance in the Grand Mesa and West Elk Mountain region, it is economically the most important formation of this region and for this reason has been subdivided for convenience of description into four parts which will be described separately. These are (1) a basal marine member, the Rollins standstone; (2) a coal-bearing marine and brackish-water member, the Bowie shale; (3) a coal-bearing freshwater member, the Paonia shale; (4) an upper undifferentiated part consisting principally of sandstone and not known to contain coal of commercial importance. These subdivisions were first used in the preliminary report on the Grand Mesa coal field ${ }^{3}$ with reference to this bulletin for fuller descriptions.

\section{ROLLINS SANDSTONE MEMBER.}

The Rollins sandstone is the basal member of the Mesaverde formation and is therefore called the basal sandstone by the coal prospectors. The name is derived from the Rollins mine, in the Grand Mesa field, where the sandstone occurs characteristically developed and forms a conspicuous white cliff, shown in Plate III, $B$, page 15 . The Rollins sandstone is a well-defined stratigraphic unit and is persistent throughout the Grand Mesa and West Elk Mountain region. -It contrasts sharply with the underlying shale and with the overlying

1 Hills, R. C., Orographic and structural features of Rocky Mountain geology: Proc. Colorado Sci. Soc., vol. $3,1888-90$, p. 382 .

2 Eldridge, G. H., Anthracite-Crested Butte folio (No. 9), Geol. Atlas U. S., U. S. Geol. Survey, 1894.

8 Lee, W. T., The Grand Mesa coal field, Colorado: Bull. U. S. Geol. Survey No. 341, 1908, pp: 316-334. 
coal-bearing rocks. In the Grand Mesa field it.ranges in thickness from 60 to 125 feet. In the fields farther east it is not so thick. It is uniformly white, coarse-grained, massive and cliff-making throughout the area here described and appears from a distance as a conspicuous white band in the sides of the mesas. (See Pl. V, A.) It can be recognized and traced in many places where the overlying coal-bearing rocks are covered with brush or rock débris. For this reason it is important as a key rock for locating the coal beds that lie above it.

The Rollins sandstone is of marine origin and contains great numbers of fossil fucoids, Halymenites major Lesq., and molluscan shells of several species, the most conspicuous of which are large marine invertebrates of the genus Inoceramus. It evidently marks the transition from the marine conditions that prevailed during the deposition of the Mancos shale to the brackish-water conditions represented by the coal-bearing rocks of the Bowie member of the Mesaverde. It is inconspicuous in the Floresta field, where it is only 30 feet thick, but is characterized there as elsewhere by Halymenites. In the Mount Carbon and Crested Butte fields it attains a maximum thickness of 85 feet or more and can usually be recognized by its fossil fucoids and characteristic mollusks. It is the massive sandstone member of the rocks that Eldridge refers to the Laramie in his description of the Anthracite-Crested Butte region.

Throughout the Grand Mesa and West Elk Mountain coal fields, Halymenites major occurs so persistently and in numbers so great in the Rollins that the sandstone for practical purposes may be regarded as characterized by that species. It is found also in the sandy layers at the top of the Mancos shale and sparingly in some of the sandstones of the overlying Bowie member of the Mesaverde, usually in those that contain marine shells. The fossils are easily recognized by their peculiar warty surface (Pl. XVI, p. 224, fig. 7), which leaves a pitted cast that is as readily recognized as the fossil itself. Some of the specimens are straight or slightly curved and others are forked. They are in places associated with marine shells and in these coal fields have not been found above the top of the Bowie shale member. Since they occur more abundantly in the Rollins sandstone than elsewhere they are especially useful to the prospector in locating the sandstone that constitutes the base of the coal measures throughout the area described. Besides Halymenites the Rollins sandstone contains a few fossil shells, which do not differ greatly from those of the underlying Mancos shale. They are not numerous and at only three localities were collections made. The fossils are given in the following list. The numerals refer to the location numbers on the accompanying map, also to the Mesozoic fossil locality records of the United States Geological Survey. 
No. 4207. Location, 9 miles northeast of Delta, Colo., at the top of the Rollins sandstone.

Halymenites major Lesq.

Ostrea sp.

Mytilus sp.

Inoceramus sp.

Leda sp.

Anatina? sp.

No. 6134. Location, Slate River valley $1 \frac{1}{2}$ miles southeast of Anthracite, at the top of the Rollins sandstone.

Halymenites major Lesq.

Ostrea subtrigonalis E. and $\mathrm{S}$.

No. 6135. Location, Slate River valley one-half mile south of Anthracite, at the top of the Rollins sandstone.

Halymenites major Lesq.

Ostrea sp.

Tellina? sp.

Lamna? sp. (shark's tooth).

BOWIE SHALE MEMBER.

The Bowie-shale derives its name from Bowie, a mining town on the north fork of Gunnison River, where it is typically developed, as shown in Plate VI, $B$, page 48 . The Bowie consists principally of shale, but in some localities, as for example near Palisades, it contains massive sandstones that make prominent cliffs. (See Pl. II, $A$, p. 14.) It is of irregular occurrence in the Grand Mesa and West Elk Mountain region and in some places is not represented. It has a maximum observed thickness of about 425 feet. It contains coal, which differs in character from the coal of the overlying Paonia shale member. As defined for this bulletin, the Bowie member includes the coal-bearing rocks near the base of the Mesaverde formation, which are distinctly of marine and brackish-water origin, as shown by the fossils collected from them. In the western part of the Grand Mesa field it includes the rocks above the Rollins sandstone member and below an unconformity (see Pl. V, B) that occurs at the base of the sediments of mainly fresh-water origin. In the eastern part of the Grand Mesa field and in the Mount Carbon field, no conspicuous unconformity was found within the coal-bearing rocks, and the line of separation between the Bowie and Paonia members is drawn at the base of the plant-bearing beds, a horizon above which no marine or brackishwater invertebrate fossils were found.

Fossil shells are very abundant in many places in the Bowie shale member, but no plants except Halymenites have yet been found in it. The shells are all of marine and brackish-water habitat. Of the marine forms the most abundant and easily recognized are Inoceramus sagensis and Inoceramus barabini. They occur in many places in the topmost sandstone and differ only in size from these same forms occurring in the Mancos shale, the shells at the higher horizon usually being much larger than those of the Mancos. 


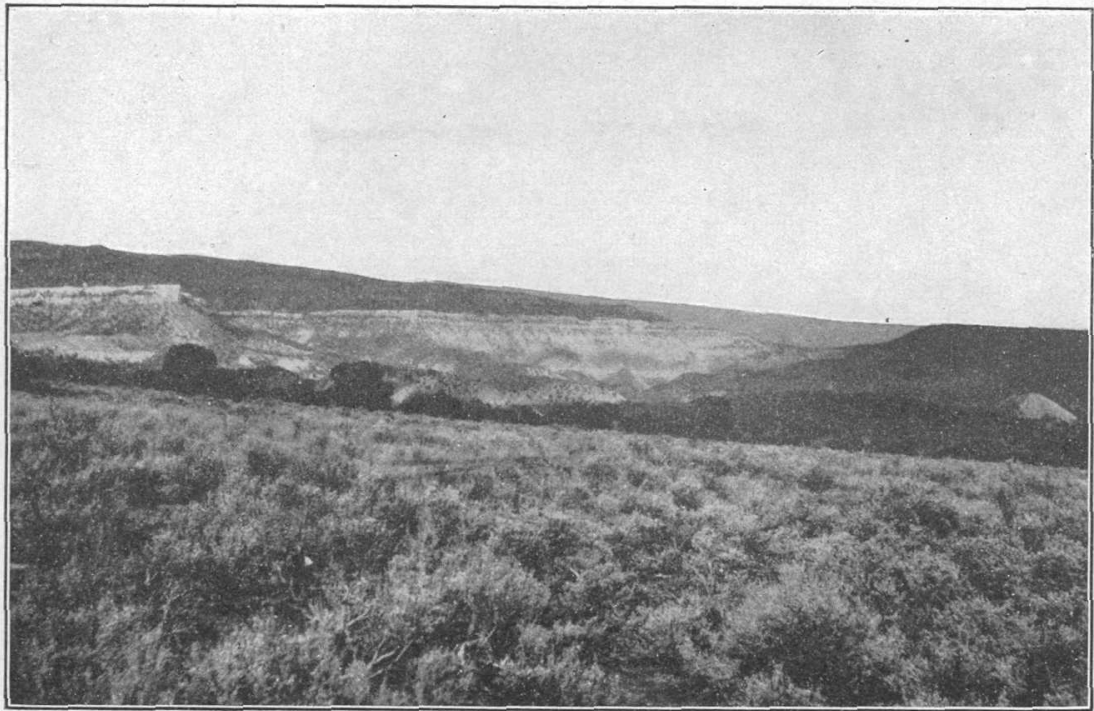

A. WEST SLOPE OF PAINE MESA.

Showing an old graded surface dissected by erosion which has revealed the underlying rocks of unequal hardness.

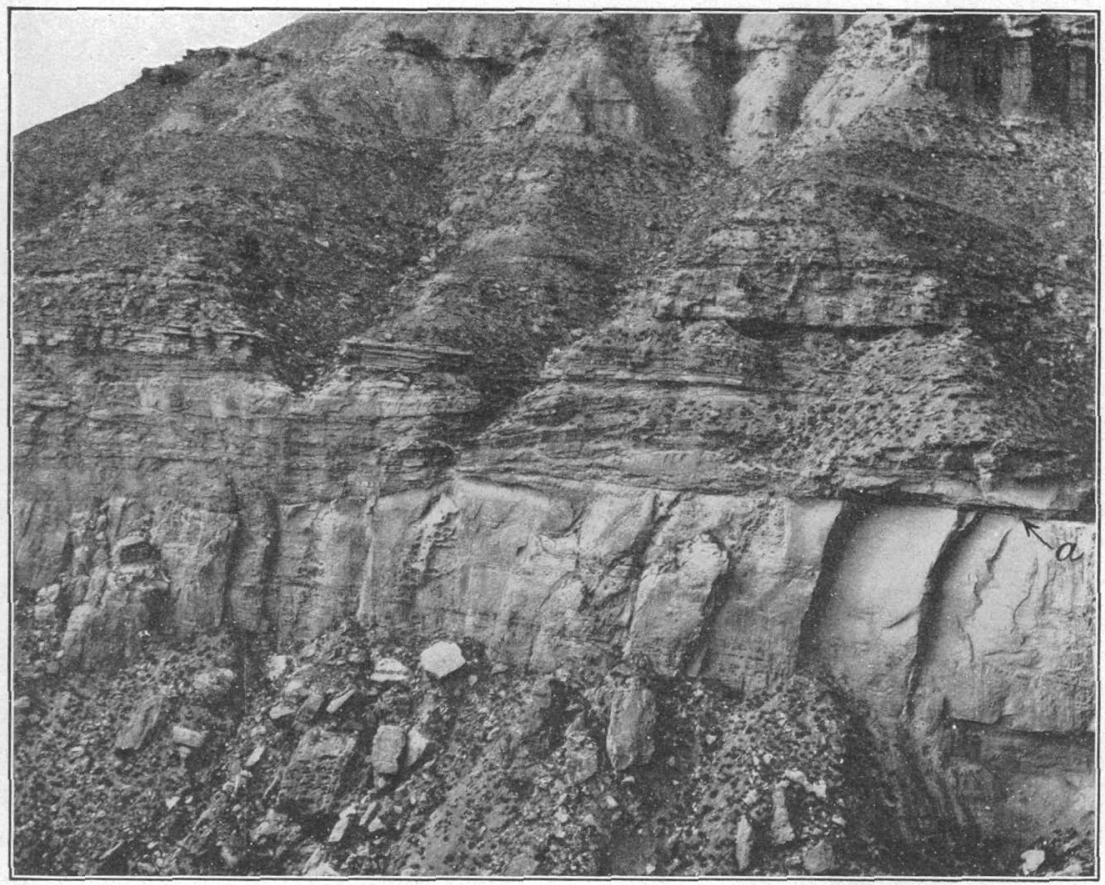

B. ESCARPMENT OF COAL-BEARING ROCKS, 3 MILES SOUTH OF PALISADES, COLO.

Showing the Paonia shale member of the Mesaverde formation lying unconformably upon the Bowie shale member of the same formation. The rocks above $a$ contain coal associated with fossil plants and fresh-water mollusks. The sandstone below $a$ contains marine shells. (Photograph by T. W. Stanton.) 
The principal localities at which shells were collected from the Bowie shale member together with the forms identified and the horizons at which they were collected are given in the following list. The numerals refer to the location numbers on the accompanying map, also to the Mesozoic fossil locality records of the United States Geological Survey.

No. 4186. Location, $3 \frac{1}{2}$ miles southeast of Palisades, Colo., and about 25 feet above the base of the Bowie.

Cardium speciosum M. and H.

Tellina sp.

Leptosolen sp.

Corbula sp.

Gyrodes sp.

Inoceramus barabini, Halymenites major and other marine forms were seen but not collected at this locality, 100 feet above the base of the Bowie.

No. 4192. Location (same as 41.86) and about 125 feet above the base of the Bowie.

Ostrea sp.

Inoceramus barabini Morton.

Cardium sp., etc.

At this locality 400 feet above the base of the Bowie were found many Inoceramus shells (compare Inoceramus erectus Meek), one of which measured $17 \frac{1}{2}$ by 20 inches. The same rock contains Halymenites major Lesq.

No. 4203. Location, 7 miles southeast of Palisades, Colo., at locality No. 11, and 25 to 200 feet above the base of the Bowie.

Leda sp.

Cardium sp.

Tellina sp.

Mactra sp.

Halymenites major and Inoceramus also were found at this locality, but none were collected.

No. 4264. Location, Conine mine, 3 miles northwest of Paonia, Colo., and 40 feet above the base of the Bowie.

Modiola laticostata White.

Corbula undifera Meek.

No. 4265. Location, 3 miles north of Paonia, Colo., at the base of the Bowie.

Corbicula cytheriformis M. and $\mathrm{H}$.

Corbicula sp.

Panopæa simulatrix Whiteaves?

No. 4266. Location, 3 miles north of Paonia, Colo., at the base of the Bowie in the roof of an old mine opening.

Corbula undifera Meek.

The specimen of Corbula undifera shown in Plate XVI, figure 4, was collected at this locality.

No. 4268. Location, 1 mile west of Bowie, Colo., at the base of the Bowie in the roof of an old mine.

Ostrea sp.

Anomia sp.

Corbula undifera Meek.

$40642^{\circ}-$ Bull. $510-12-3$ 
No. 4271. Location, one-half mile northwest of Bowie, Colo., at the base of the Bowie in the roof of the old King mine.

Anomia micronema Meek.

Corbicula cytheriformis M. and $\mathrm{H}$.

Corbicula sp.

Corbula subtrigonalis $\mathrm{M}$. and $\mathrm{H}$.

No. 4269. Location, one-half mile north of Bowie, Colo., near the base of the Bowie. Anomia sp.

Modiola regularis White.

Corbicula cytheriformis $\mathrm{M}$. and $\mathrm{H}$.

Ostrea sp.

No. 4487. Location, one-half mile north of Bowie, Colo., 25 feet above the base of the Bowie.

Anomia sp.

Ostrea subtrigonalis $\mathrm{E}$. and $\mathrm{S}$.

Corbicula occidentalis $\mathrm{M}$. and $\mathrm{H}$.

Corbula undifera Meek.

No. 4275. Location, Hubbard Creek, Colo., 20 feet above the base of the Bowie.

Ostrea subtrigonalis E. and $\mathrm{S}$.

Modiola regularis White.

Anomia sp.

Corbicula cytheriformis M. and $\mathrm{H}$.

Corbula subtrigonalis $\mathrm{M}$. and $\mathrm{H}$.

Corbula undifera Meek.

Panopæa simulatrix Whiteaves?

The specimen of Corbicula cytheriformis shown in Plate XVI, figure 6, was collected at this locality, and the specimen of Ostrea subtrigonalis figured as No. 5 of the same plate was collected near this locality.

No. 4274. Location, Hubbard Creek, Colo., in slide rock near the top of the Bowie.

Anomia micronema Meek.

Modiola regularis White.

Corbicula cytheriformis $\mathrm{M}$. and $\mathrm{H}$.

Corbicula sp.
Corbula subtrigonalis $\mathrm{M}$. and $\mathrm{H}$.

Corbula undifera Meek.

Melania insculpta Meek.

Goniobasis cf. tenuicarinata $\mathrm{M}$. and $\mathrm{H}$.

No. 4488. Location, $1 \frac{1}{2}$ miles southeast of Bowie, Colo, about 50 feet above the base of the Bowie.

Modiola laticostata White.

Corbula undifera Meek.

No. 4499. Location, Minnesota Creek, 7 miles east of Paonia, Colo., near the base of the Bowie.

Ostrea subtrigonalis E. and S.

Anomia sp.

Modiola regularis (White).

Corbicula sp.

Corbula sp.

Melania wyomingensis Meek.

Melania insculpta Meek.

The specimen of Melania insculpta shown in Plate XVI, figure 3, was collected at this locality.

No. 4500. Location, Minnesota Creek, 9 miles southeast of Paonia, Colo., near the base of the Bowie.

Ostrea subtrigonalis $\mathbf{E}$. and $\mathrm{S}$.

Anomia sp.

Corbicula.

Corbula subtrigonalis $\mathrm{M}$. and $\mathrm{H}$.

Melania insculpta. 
No. 4501. Location, Minnesota Creek, 9 miles southeast of Paonia, Colo., near the top of the Bowie.

Inoceramus sagensis Owen.

These shells are very numerous at this locality.

No. 4503. Location, Coal Creek at locality No. 52 near the top of the Bowie.

Ostrea sp.

Leda sp..

Cardium speciosum $\mathrm{M}$. and H.

Tellina sp.

Mactra sp.

No. 6138. Location, Coal Creek near the mouth of Robinson Creek, Colo.

Ostrea sp.

Anomia sp.

Modiola sp.

Corbicula? sp.

No. 6136. Location, near Mount Carbon, Colo., at locality No. 81 above the lowest coal bed.

Anomia sp.

Inoceramus barabini Morton.

No. 6137. Location, about 4 miles south of Mount Carbon, Colo., at locality No. 85 above the lowest coal bed.

Anomia sp.

Inoceramus barabini Morton.

Cardium speciosum $\mathrm{M}$. and $\mathrm{H}$.

Mactra sp.

The following is a list of all fossils collected from the Bowie shale member, including those named in the foregoing lots:

Fossils from the Bowie shale or marine and brackish-water coal-bearing member of the Mesaverde formation.

[Identified by T. W. Stanton.]

Halymenites major Lesq.

Ostrea sp.

Mytilus sp.

Inoceramus barabini Morton.

Inoceramus sagensis.

Inoceramus cf. erectus Meek.

Leda sp.
Marine forms.

Cardium speciosum M. and H.

Tellina sp.

Leptosolen sp.

Anatina sp.

Mactra sp.

Gyrodes sp.

Lamna sp. (shark tooth).

\section{Brackish-water forms.}

Ostrea subtrigonalis E. and S. Anomia micronema Meek.

Anomia sp.

Modiola laticostata White.

Modiola régularis White

Corbicula cytheriformis M. and H.

Corbicula occidentalis M. and H.

Panopæa simulatrix Whiteaves?

Corbula subtrigonalis M. and H.

Corbula undifera Meek.

Melania insculpta Meek.

Melania wyomingensis Meek. 
In his report on these fossils Dr. Stanton says:

They consist of (1) marine Cretaceous fossils belonging to the fauna of the Montana group, most of the species having a considerable vertical range, many of them occurring in both the upper part of the Mancos and the lower part of the Mesaverde, so that there is no sharp faunal distinction between Mancos and the marine portions of the Mesaverde; (2) brackish-water species, of types that occur in the Laramie and also in lower horizons like the Mesaverde and Judith River in the Montana group.

At the west end of the Grand Mesa field, where the Bowie member is about 425 feet thick, it consists principally of massive sandstone and contains only one coal bed. It is mainly of marine origin and fossil shells of the genus Inoceramus occur in the highest sandistone of the member. There are indications in this vicinity of an unconformity by erosion between the Bowie member and the overlying Paonia member. Near Palisades there is an abrupt transition from the massive sandstone containing marine shells to the overlying coalbearing shale containing plants and fresh-water shells. About 3 miles farther south, this line of separation is sinuous and suggests an eroded surface upon which the younger beds were deposited. (See Pl. V, B, p. 32.) Still farther south the Bowie member becomes thin and near Pickett Range disappears, allowing the Paonia shale with its associated coal, fossil plants, and fresh-water shells to rest upon the Rollins sandstone.

No indication of the Bowie member was found between this point and the town of Paonia, a distance of about 35 miles. Throughout this distance the Paonia shale rests upon the Rollins with apparent unconformity, as shown in section 2 of figure 3, page 50, but farther east the Bowie shale occurs, although the point at which it reappears is not definitely known. Marine shells were found in this shale near the Conine mine (locality No. 35 of the accompanying map), but 5 miles farther west near the Burdick mine (locality No. 32), rocks containing fossil plants and fresh-water shells were observed a few feet above the Rollins sandstone. The western extremity of the Bowie in this part of the Grand Mesa field apparently lies somewhere between these two localities and the rocks extend thence uninterruptedly eastward to the eastern end of the Grand Mesa field, where they disappear under younger rocks. In the eastern part of the field the Bowie beds consist of carbonaceous shale, sandstone, and coal, all of which apparently occur in more or less lenticular bodies. There are seven beds of coal that have been prospected, and others of which nothing is known beyond the fact that clinker beds indicate the horizons at which they may be found. The coal-bearing shales contain large numbers of brackish-water fossils, and the non coal-bearing beds, especially those near the top, contain marine fossils of which large shells of the genus Inoceramus are the most conspicuous.

No evidence of an unconformity was found between the Bowie and Paonia members east of Paonia, perhaps because of poor exposures, 
and in the Coal Creek district the failure to find fossils at critical points renders the line marking the top of the Bowie member uncertain. A prominent sandstone underlies the lowest bed of coal in the rocks that contain fossil plants. No fossils were found in this sandstone, but it is similar in appearance and general field relations to the highest marine sandstone of the Bowie member in the Somerset district. Oyster shells and sharks' teeth were found a few feet below it and fossil plants a few feet above it. For these reasons the line of separation between the Bowie and Paonia members of the Mesaverde in the Coal Creek district is drawn provisionally at the top of this sandstone.

No fossils were found in the Floresta field that would prove the presence of the Bowie member, but the association of plant remains with the lowest coal indicates that if this member is present it is confined to some part of the 115 feet of shale intervening between this coal and the top of the Rollins sandstone.

In the Mount Carbon field the lowest coal occurs in rocks of brackish-water origin, which probably belong to the Bowie member, but the next higher coal bed, 85 feet above the base of the coal measures, is associated with plant remains and is regarded as younger than Bowie.

In the Crested Butte field the writer failed to find rocks of brackishwater origin above the lowest coal, but Eldridge states in Geologic Folio No. 9 that "molluscan remains of brackish-water and freshwater origin occur somewhat sparsely distributed throughout the series." Oyster shells and other brackish-water forms occur in some places in beds a few feet above the top of the Rollins sandstone, but the lowest coal, which in some places rests directly on this sandstone, is associated with fossil plants similar to those of the Paonia shale. Unfortunately Eldridge's notes and collections from this region are not to be found, and there is no way of ascertaining where he found the brackish-water fossils referred to in the passage quoted.

The separation of the rocks that are referred to the Bowie member of the Mesaverde from other rocks of the Mesaverde formation is based largely on the occurrence in them of marine and brackish-water shells and the presence of a line of unconformity between the two members at the western extremity of the Grand Mesa field. It is recognized that brackish-water shells may yet be found at higher horizons in the Mesaverde, but a careful search for them by the writer failed to reveal the presence of such fossils above rocks containing fossil leaves, with the single exception of one species noted on page 30 . The segregation into a distinct member of the coalbearing rocks, which are clearly of marine and brackish-water origin, from the overlying rocks, which are mainly of fresh-water origin, and the extension of this member throughout the region described is based upon four considerations. These are (1) the obvious erosion at the close of the Bowie epoch in the western part of the Grand Mesa field; 
(2) the absence of the Bowie member from the central part of this field and its reappearance in the eastern part; (3) the presence of marine and brackish-water fossils above the lowest coal in the Mount Carbon field and the thinning out of the marine beds eastward, allowing the overlying plant-bearing rocks to come in contact with the Rollins sandstone; and (4) the absence from the Crested Butte field of rocks of marine or brackish-water origin immediately above the Rollins sandstone. These facts are all in accord with the postulate that early in Mesaverde time salt and brackish water covered considerable parts of the Grand Mesa and West Elk Mountain region. The localities where the Bowie beds are not found may have been areas of nondeposition, but it is equally rational and more nearly in keeping with the observed facts to assume that these beds were deposited over those areas and were subsequently eroded. The final decision must await further investigation. It would be obviously inappropriate to include in a single formation beds above and below the unconformity, if this should prove to be as widespread as now seems probable. The beds have been so grouped in the present bulletin, in deference to the opinion of investigators in neighboring fields where no unconformity was found in rocks that have been correlated directly with the coal-bearing rocks of Grand Mesa and the West Elk Mountains.

\section{PAONIA SHALE MEMBER.}

The name Paonia is derived from a town on the North Fork of Gunnison River, near which the rocks of this member are typically exposed. Unlike the Rollins sandstone and the Bowie shale members, the Paonia member does not form a well-defined stratigraphic unit. It is the coal-bearing portion of the fresh-water division of the Mesaverde formation. Its lower limit can be definitely drawn at the contact with the rocks containing marine fossils, but the upper limit is not sharply defined, the rocks differing from the overlying beds, which also contain fresh-water fossils, only in the predominance of shale and in the presence of coal. In the overlying beds sandstone predominates. In the Anthracite-Crested Butte region, the Paonia shale corresponds to the "productive measures" described by Eldridge. This member varies in thickness from less than 200 to about 475 feet and contains great numbers of fossil leaves and shells of fresh-water mollusks. Economically the most important character of this member and the one that justifies a separate name is the relative inferiority of its coals. Where the beds of both coalbearing members are undisturbed the Paonia coals are softer, lower in fuel-value, and otherwise inferior to the coals of the Bowie shale. (See fig. 37, p. 211.) This inferiority is revealed in a conspicuous manner by the more extensive burning of the coal at the outcrop and by the rapidity with which it slacks on exposure to the weather. The Bowie coals are less likely to take fire at the outcrop and do not 
deteriorate rapidly on exposure. These differences do not hold in the West Elk Mountains, where all of the coals have been metamorphosed more or less. Since the Paonia shale member is not definitely separated from the overlying part of the Mesaverde, the fossils collected from both, mainly in the Grand Mesa field, are included in the following list:

Fossils from the Paonia shale member and the overlying part of the Mesaverde formation.

Flora.

Pteris russellii Newberry.

Equisetum sp.

Sequoia brevifolia? Lesq.

Sequoia reichenbachi (Gein.) Heer.

Sequoia sp.

Cyperacites sp.

Eriocaulon? porosum Lesq.

Geonomites ungeri Lesq.

Sabalites? sp.

Salix n. sp.

Populus sp.

Myrica torreyi Lesq.

Myrica sp.

Myrica new sp.

Platanus aceroides Goppert.

Ficus speciosissima Ward.

Ficus planicostata Lesq.

Ficus occidentalis Lesq.

Ficus planicostata latifolia Lesq.

Ficus trinervis Knowlton.

Ficus rhamnoides? Knowlton.

Ficus oblanceolata? Lesq.

Ficus sp.

Aralia sp.

Diospyros? sp.

Cinnamomum? sp.

Viburnum montanum? Knowlton.

\section{Fauna.}

Unio cf. brachyopisthus White.

Unio cf. endlichi White.

Unio cf. holmesianus White.

Unio sp. (several undescribed species).

Sphærium sp.

Tulotoma thompsoni White.

The Paonia shale member is continuous throughout the Grand Mesa and West Elk mountain coal fields. At the west end of the Grand Mesa field it lies unconformably on the Bowie member, as previously described. In the center of this field it rests unconformably upon the Rollins sandstone member. (See figs. 3 and 7, pp. 50, 79.) In the eastern part of the field its relation to the Bowie member is probably the same as in the western part, although no evidence of unconformity was found. Throughout the field the rocks consist principally of soft shale, although in some places sandstone layers attain considerable prominence.

In the fields east of Grand Mesa no good reasons, aside from the character of the fossils, were found for separating the coal-bearing, rocks into members, and this separation would not have been deemed necessary had not their relations in the Grand Mesa field been determined previous to the time of investigation in the fields farther east. However, the character of the rocks and the fossils that they contain apparently warrant the extension of the subdivisions made in the Grand Mesa field over the entire area here described. 
In the Mount Carbon field all of the coal at the eastern end and all except the lowest bed at the western end is associated with fossil plants similar to those of the Paonia member of the Mesaverde in the Grand Mesa field. In the Crested Butte field all of the coals, except perhaps the lowest bed, which is not everywhere present, are associated with fossil leaves most conspicuous among which are palm and fig leaves identical with those of the Paonia member in the Grand Mesa field. These leaf-bearing coal measures are here correlated with the Paonia member, although Eldridge's statement previously quoted, to the effect that brackish-water fossils occur throughout the coal measures of the Crested Butte region, casts some doubt upon the validity of any subdivision of the coal-bearing rocks in the eastern part of the area described.

The Paonia shale contains great numbers of fossil plants. Nearly all of the species named in the foregoing list were collected from this member. A few were found in the beds of the Mesaverde that overlie the Paonia, but none is known to be restricted to those beds. Some of the most abundant and conspicuous species of fossil plants are shown in Plates XVIII to XXI at the end of this bulletin. The fig leaves (Ficus) are very abundant. Ficus speciosissima was found in practically every locality examined. It is easily recognized even in small fragments by the conspicuous venation. (See Pl. XVIII, No. 1.) Ficus trinervis and Ficus occidentalis are almost equally abundant. Palm leaves occur in many places and are readily recognized. The most common species is Geonomites ungeri (see Pl. XVIII), which is characterized by a long midrib from which the rays diverge. Some of the other leaves, as for example Myrica torreyi and Pteris russellii, are less abundant but rather conspicuous where they occur. Doubtless some of the forms that are not illustrated in this bulletin are as important from a scientific standpoint as the ones thus singled out. But from an economic standpoint, the eight species shown in the accompanying illustrations together with the fresh-water shells referred to in the following paragraphs probably best characterize the Paonia member of the Mesaverde and will be referred to again in the economic part of this bulletin. (See pp. 217-219.)

The principal localities at which Paonia plants were collected together with the forms identified and the horizons at which they occur are as follows: The numerals refer to the record numbers of these fossils in the collections of the United States Geological Survey.

No. 4336. Location, $3 \frac{1}{2}$ miles southeast of Palisades, Colo., and 300 feet above the base of the Paonia. Near location marked 4184 on the accompanying map.

Sequoia reichenbachi (Gein.) Heer.

Geonomites ungeri Lesq. 
No. 4337. Location, $3 \frac{1}{2}$ miles southeast of Palisades, Colo., and 150 feet above the base of the Paonia. At the place marked 4195 on the map.

Pteris russellii Newberry.

Sequoia reichenbachi (Gein.) Heer.

Eriocaulon? porosum Lesq.

Geonomites ungeri? Lesq.

Diospyros? sp.

Ficus planicostata Lesq.

Ficus occidentalis Lesq.

Platanus aceroides Gopp.

Aralia sp.

Tulotoma thompsoni was found with the leaves. For other shells from this horizon see No. 4195, page 42.

No. 4345. Location, 9 miles southeast of Palisades, east of Pickett Ranch, 50 feet above the base of the Paonia.

\begin{tabular}{l|l} 
Sequoia reichenbachi (Gein.) Heèr. & Ficus planicostata latifolia Lesq.
\end{tabular}

Ficus speciosissima Ward.

Ficus planicostata? Lesq. Myrica torreyi? Lesq.

Myrica n. sp.?

Palm leaves also occur at this locality, but none were collected.

No. 4348. Location, point east of Rollins mine, locality No. 19, 100 feet above the base of the Paonia.

Sequoia reichenbachi (Gein.) Heer.

Ficus trinervis Knowlton.

Ficus speciosissima Ward.

Ficus rhamnoides? Knowlton.

Sabalites? sp.?

At this locality, 50 feet above the base of the Paonia, the following forms not represented in the list above were collected: Myrica torreyi, and Geonomites ungeri. For shells collected at this locality see No. 4205 , page 42 .

No. 4353. Location, canyon of Dirty George, 13 miles northeast of Delta, Colo., 40 feet above the base of the Paonia.

Ficus speciosissima Ward.

Ficus trinervis Knowlton.

Myrica torreyi? Lesq.

No. 4387. Iocation, Hubbard Creek, at the base of the Paonia.

Equisetum sp.

Sequoia reichenbachi? (Gein.) Heer.

Myrica torreyi? Lesq.

No. 5591. Location, east of Mount Wheatstone, locality No. 110, at the base of the Paonia.

Sequoia reichenbachi (Gein.) Heer. .

Sequoia brevifolia Heer.

Ficus speciosissima Ward?

No. 5583. Location, in Slate River valley 1 mile northwest of Crested Butte, in the roof of an old mine $150+$ feet above the base of the Paonia.

Geonomites ungeri Lesq.

Ficus sp. Type of F. speciosissima Ward but probably new.

Ficus sp. Type of F. planicostata Lesq. but probably new.

Fragments of other dicotyledons.

No. 5589. Location, in Slate River valley 2 miles northwest of Crested Butte, in the upper workings of the Silverbrook mine.

Ficus.speciosissima Ward.

Ficus sp. Type of F. oblanceolata.

Stems and fragments of leaves that are not determinable

Large palms, probably Geonomites ungeri, are numerous in the roof of this mine, but could not be collected. One specimen measured 41 inches in length. 
No. 5592. Location, Kubler mine, near. Mount Carbon, locality No. 100, near the base of the Paonia.

Geonomites ungeri Lesq.

The roof shale of the Kubler mine has a great variety of netted-veined leaves, but no satisfactory collection could be made.

Fossil shells occur abundantly in many places in the Paonia shale member but are not so widely distributed as are the fossil leaves. They often occur in vast numbers in masses or pockets. The most conspicuous shells belong to the genus Unio and there are several species, two of which are shown in Plate XVII (p. 226). However, the Unios are much less numerous than the coiled gastropods. Probably the most common of the gastropods is Campeloma (Pl. XVII), although it is usually associated with other gastropods of the genus Viviparus. Probably the next most abundant shell and the one most likely to attract attention in the field is Tulotoma thompsoni. (See Pl. XVII.) It does not occur in masses as do the Unios and Campelomas but is found singly and sometimes in leaf-bearing beds.

The principal localities at which the fresh-water shells of the Paonia shale member were collected together with the forms identified and the horizons at which they occur are as follows. (The numerals refer to corresponding locality numbers on the accompanying map and to the Mesozoic fossil locality records of the United States Geological Survey.)

Although the fauna of the Paonia shale member is referred to as a fresh-water fauna, it contains Corbula subtrigonalis, which in the Grand Mesa field is found associated with both fresh-water and brackish-water species.

No. 4184. Location, $3 \frac{1}{2}$ miles southeast of Palisades, Colo., about 250 feet above the base of the Paonia.

Unio sp.

Unio cf. holmesianus White.

Tulotoma thompsoni White.

Campeloma? sp.

Viviparus sp.

Palm leaves also occur at this horizon.

No. 4195. Location, $3 \frac{1}{2}$ miles southeast of Palisades, Colo., 150 feet above the base of the Paonia.

Unio sp.

Sphærium sp.

Corbula subtrigonalis $\mathrm{M}$. and $\mathrm{H}$.

Physa cf. felix White.

Viviparus sp.

Campeloma? sp.

Tulotoma thompsoni White.

For plant remains collected at this horizon, see No. 4337, page 41.

No. 4205 . Location, point east of Rollins mine, 75 feet above the base of the Paonia.

- Unio sp.

Sphærium sp.

Corbula subtrigonalis $\mathrm{M}$. and $\mathrm{H}$.

Tulotoma thompsoni White.

Goniobasis? sp.

Campeloma? sp.

The specimen of Corbula subtrigonalis shown in Plate XVII, figure 5, was collected at this locality. 
No. 4218. Location, 14 miles northeast of Delta, Colo., at locality No. 24, 100 feet above the base of the Paonia.

Unio cf. brachyopisthus White.

Unio cf. endlichi White.

Unio sp.

Tulotoma thompsoni White.

Campeloma? sp.

Nos. 4220 and 4221. Location, 4 miles northeast of Cedaredge, Colo., 200 ieet above the base of the Paonia.

Unio cf. endlichi White.

Unio cf. brachyopisthus White.

Unio several species.

Tulotoma thompsoni White.

Viviparus sp.

Campeloma? sp.

The fossils at this locality are unusually well preserved. The specimens of Campeloma? sp., Unio cf. U. brachyopisthus, Unio cf. U. endlichi, and Tulotoma thompsoni shown in Plate XVII, figures 1-4, and 6, were collected bere.

No. 4263. Location, 6 miles north of Hotchkiss, Colo., 100 feet above the base of the Paonia.

Unio sp.

Corbula subtrigonalis $\mathrm{M}$. and $\mathrm{H}$.

Viviparus sp.

Nos. 4504 and 4505. Location, Coal Creek canyon at locality No. 49, near the base of the Paonia.

Tulotoma thompsoni White.

Campeloma? sp.

Viviparus?

In his report on these fossils, with which were included at that time those from the part of the Mesaverde overlying the Paonia described beyond, T. W. Stanton says:

Although this nonmarine fauna contains many Laramie elements, on the whole it agrees better with the fauna of the Mesaverde as we are now beginning to know it, and the stratigraphic and structural evidence of the entire region, including the Durango, Grand Hogback, and Yampa fields, is strongly in favor of referring all the upper coalbearing beds of the Grand Mesa field to the Mesaverde.

\section{UNDIFFERENTIATED PART OF THE MESAVERDE.}

The part of the Mesaverde formation above the Paonia shale is not known to be of great economic importance. It contains little workable coal, a 40-inch bed in the eastern part of the Grand Mesa field being apparently of local occurrence. The rocks, about 1,500 feet thick, consist principally of sandstone in thick, massive layers separated by shale, as illustrated in Plate II, $B$, page 14 . Shells of freshwater mollusks and plants of the same species as those in the Paonia shale were found at several horizons, but no marine shells and only a few brackish-water shells, such as Corbula subtrigonalis, have yet been found in these beds in the Grand Mesa and West Elk Mountain coal fields. Investigators who have examined the neighboring fields report the occurrence of marine and brackish-water fossils from beds near the top of the formation with which the coal-bearing rocks of Grand Mesa have been correlated. 
The nearest recorded occurrence of these fossils is more than 100 miles north of the Grand Mesa field in Lion Canyon on White.River, $\dot{4}$ miles west of Meeker, Colo., where H. S. Gale and T. W. Stanton ${ }^{1}$ found the following fossils:

Cardium speciosum M. and $\mathrm{H}$.

Corbicula cytheriformis $\mathrm{M}$. and $\mathrm{H}$.

Corbicula fracta Meek.

Corbula subtrigonalis $\mathrm{M}$. and $\mathrm{H}$.

Corbula undifera Meek.

Mactra? sp.

Modiola sp.

Ostrea subtrigonalis $\mathbf{E}$. and $\mathbf{S}$.

Ostrea glabra M. and $\mathrm{H}$.

Ostrea glabra var. arcuatilis.

This upper noncoal-bearing division extends eastward under the cover of younger rocks in the central part of the area described and reappears in the eastern part with character unchanged. These rocks in the Crested Butte field, like those of the undifferentiated part in the Grand Mesa field, consist of massive plates of sandstone separated by layers of shale (see Pl. XIII, $B$, p. 170) and contain no coal known to be of economic importance.

The principal localities at which fossils were collected from the upper or undifferentiated part of the Mesaverde formation, together with the forms identified and the horizons at which they occur are given in the following list. The numerals refer to corresponding locality numbers on the accompanying map and also to locality records of the United States Geological Survey.

No. 4335. Location, 3 miles northeast of Palisades, Colo., about 1,000 feet below the top of the Mesaverde (at locality marked 4188).

Sequoia brevifolia? Lesq.

Ficus speciosissima Ward.

Ficus sp.?

Myrica torreyi Lesq.

For shells at this locality see No. 4188 , below.

No. 4338. Location, 4 miles southeast of Palisades, Colo., at the top of the Mesaverde.

Ficus speciosissima Ward.

Ficus sp.

No. 4383. Location, Hubbard Creek about 3 miles north of its mouth, near the base of the upper or undifferentiated part of the Mesaverde.

Ficus speciosissima Ward.

Ficus probably new.

Salix n. sp. ?

Myrica torreyi Lesq.

No. 4191. Location, $1 \frac{1}{2}$ miles northeast of Cameo, Colo., 800 feet below the top of the Mesaverde.

Unio sp.

Tulotoma, thompsoni White.

Campeloma? sp.

No. 4188. Location, Rapid Creek 3 miles northeast of Palisades, Colo., about 1,000 feet below the top of the Mesaverde.

Sphærium sp.

Physa cf. felix White.

Goniobasis cf. tenuicarinata M. and $\mathrm{H}$.

For plants at this locality see No. 4335 , above. 
No. 4214. Location, 12 miles northeast of Delta, Colo., about 600 feet below the top of the Mesaverde.

Unio sp.

Tulotoma thompsoni White.

Viviparus sp.

Campeloma? sp.

No. 4486. Location, 12 miles northeast of Delta, Colo., 300 feet below the top of the Mesaverde.

Unio, casts of 2 or 3 species.

Teredo? or Pholas?, calcareous tubes resembling those of a burrowing pelecypod. Viviparus sp.

Campeloma? sp.

There is obviously no paleontologic reason for separating the Paonia shale member from the overlying beds, and the two may be considered together in discussing the geologic age. As already indicated in describing the invertebrate faunas, there is apparently good reason for correlating these members with the upper part of the formation described as Mesaverde in neighboring fields. On the other hand the evidence of the fossil plants seems to indicate that this correlation is open to question. There is no doubt that the coal-bearing rocks throughout the Grand Mesa and West Elk Mountain coal fields are the same as those in the Anthracite-Crested Butte region that until recently were regarded as Laramie. Because of the apparently conflicting evidence, Knowlton's summary of the data derived from the fossil plants is quoted somewhat fully as follows:

At the request of $\mathrm{W}$. T. Lee I have made a re-study of the fossil plant collections from the Grand Mesa and West Elk Mountain coal fields of Colorado together with such other collections as are available from adjacent or more remote but obviously related areas. Since the preliminary studies of the Grand Mesa plants were made, specimens have been collected in the Glenwood Springs area in beds in stratigraphic connection with those affording the plants in the Grand Mesa field. In addition to these a typical Laramie flora similar to that of the Denver Basin has been developed in Carbon County, Wyoming, and very full collections obtained from the so-called "Laramie" at Black Buttes, Wyoming. This additional material has thrown important light on a number of the forms involved and has made necessary some slight changes in specific limits.

On eliminating the collections of unknown or doubtful stratigraphic position and correcting for the slight changes in specific limits adopted, we have the following list of named forms in the field under consideration:

Pteris russellii.

Sequoia brevifolia?

Sequoia reichenbachi.

Eriocaulon? porosum.

Geonomites ungeri.

Myrica torreyi.

Platanus aceroides.

Ficus speciosissima.

Ficus planicostata.

Ficus planicostata latifolia.

Ficus trinervis.

Ficus rhamnoides?

Ficus oblanceolata?

Ficus occidentalis.

Viburnum montanum?

Magnolia tenuinervis.

A somewhat complete analysis of the vertical and geographic distribution of the above species will be of interest in the present connection. 
The only fern in the collection is Pteris russellii, which came originally from Vermejo Canyon, N. Mex., from beds supposed to be above the unconformity described by Lee ${ }^{1}$ in the Raton region. So far as known to me, it has not been found at any other locality. Its affinity is undoubtedly with what Lesquereux called Pteris erosa or Pteris undulata from the Denver formation of the Denver Basin.

Of the two conifers present in these collections, Sequoia reichenbachi is most abundant, but it is of little value in fixing the age, as it is known to range, if always correctly determined, from the Upper Jurassic throughout the entire Cretaceous system and into the lowest Tertiary. Sequoia brevifolia, which has been somewhat questionably identified in the Paonia shale member, is known in this country, as identified by Lesquereux, from the Montana at Point of Rocks and Rock Springs, Wyo., and Durango, Colo.

Eriocaulon? porosum is a very peculiar plant, which makes its positive identification possible under all circumstances. Its type locality is Sand Creek, in the Denver Basin, Colorado, in beds of Arapahoe age, and it has since been found in the Laramie at Murphy's coal mine on Coal Creek and at Erie, both in Boulder County, Colo,, and also found at Black Buttes, Wyo., near Lay, Colo., and in the Book Cliffs.

The type locality of Geonomites ungeri is the Raton Mountains of Colorado, undoubtedly above the unconformity-as reported in that region by Lee-and it has been found at a number of places in a similar stratigraphic position in the Raton-Trinidad fields as well as in the San Juan region of New Mexico.

Myrica torreyi is one of the most abundant and characteristic forms in the present collections as well as in those from Glenwood Springs area and farther north. Its type locality is Black Buttes, Wyo., where it is exceedingly abundant, and it occurs in the Laramie at Crow Creek, Colu. One or two specimens have been found in the Montana at Point of Rocks and Harper's station on the Union Pacific Railroad, Laramie Plains, Wyo. It has also been reported from a number of other points in southern Colorado.

Platanus aceroides is an exceedingly abundant form in the upper beds at Carbon, Wyo., and occurs also at Black Buttes, Wyo., in the Denver formation at Golden, Colo., and sparingly in the Livingston formation of Montana. It is apparently not known from the Montana formation.

Of the several species of Ficus, the largest and most conspicuous is Ficus speciosissima, which was described originally from Point of Rocks, Wyo. The largest leaves referred to this species appear very distinct from any other species, but the smaller leaves grade into and are absolutely indistinguishable from leaves of Ficus planicostata latifolia, the type of which comes from Black Buttes.

Ficus planicostata was described originally from Black Buttes, Wyo., where it is exceedingly abundant. It has since been found in the Denver formation at Golden, Colo.; in the Laramie at Coal Creek and Marshall, Colo.; and doubtfully in the Montana at Point of Rocks and Laramie Plains, Wyo., and Coalville, Utah. It is more abundantly and typically developed at Black Buttes and the Laramie localities of the Denver Basin. The variety latifolia of the last mentioned species has already been alluded to above.

Ficus trinervis has Black Buttes as its type locality and has also been reported from the Laramie at Marshall and near Denver, Colo., and doubtfully from Point of Rocks, Wyo., and a number of other localities, some of which at least are above rocks of Laramie age.

Ficus rhamnoides, whose presence here depends on a single poorly preserved specimen, was described originally from Point of Rocks, Wyo. Similarly Ficus oblanceolata is doubtfully identified as present in the Grand Mesa field. It came originally from Erie, Colo., from beds of Laramie age, and has been reported from Black Buttes.

1 Lee, W. T., Unconformity in the so-called Laramie of the Raton coal field, New Mexico: Bull. Geol. Soc. America, vol. 20, 1909, pp. 357-368. 
The only remaining species is Ficus occidentalis, whose type locality is the Denver formation in the Denver Basin.

Viburnum montanum? is represented in this area by a single doubtfully identified example; its type locality is Point of Rocks, Wyo.

The final species to be considered is Magnolia tenuinervis. The type locality is the Denver formation at Golden, Colo.; it has since been found at Black Buttes, Bridger Pass, and Hodges Pass, and is reported very doubtfully from Coalville, Utah.

On segregating the above data the following facts are brought out:

\section{Species found only in the Montana formation.}

Ficus speciosissima.

Sequoia brevifolia?
Ficus rhamnoides?

Viburnum montanum?

Of these four species it will be observed that only one is positively determined, the others resting on either a single specimen or fragmentary and doubtfully determined specimens.

\section{Species found only in post-Montana beds.}

Pteris russellii.

Geonomites ungeri.

Ficus planicostata latifolia.
Ficus oblanceolata?

Ficus occidentalis.

Platanus aceroides.

Only one of these is regarded as doubtfully determined.

Of the four species Myrica torreyi, Ficus planicostata, Ficus trinervis, and Magnolia tenuinervis, the first three have Black Buttes, Wyo., as type locality, where they are very abundant as they are also in the beds of the Grand Mesa and adjacent areas. In beds of acknowledged Montana age they are either very rare, of exceptional occurrence, or doubtfully identified.

In addition to the forms that have been specifically named there are present unnamed or undetermined species in the genera Equisetum, Sequoia, Cyperacites, Sabalites, Salix, Populus, Myrica, Ficus, Aralia, Diospyros, Cinnamomum, etc. Although some of these genera might be either Montana or post-Montana, others of them are distinctly of post-Montana facies.

In conclusion I feel justified in stating that in my opinion the beds containing the plants here under discussion are of post-Montana age. The facts upon which this conclusion is based are (1) 'the apparently satisfactory demonstration of an unconformity between the lower and upper coal-bearing rocks, (2) the fact that the marine invertebrates are confined to the beds below the unconformity, (3) the fact that the plants are confined to the beds above the unconformity, (4) the marked difference in the quality of the coals in the lower and upper beds, that is, below and above the unconformity,. (5) the marked resemblance between the plants of the Grand Mesa field and those of Black Buttes, Wyo., which is only a short distance north, and (6) when the first report was given, comparisons of the plants were made with areas then tentatively regarded as probably Montana in age, but which subsequent investigation has shown beyond much question to be of post-Montana age.

If the discussions and comparisons made above had included the adjacent Glenwood Springs area, with which there is stratigraphic connection, the post-Montana facies would be even more apparent. In the latter area are found such distinctively postMontana forms as Zizyphus fibrillosus, Cinnamomum affine, Populus meekii?, Populus monodon, Viburnum contortum, etc., which have not been noted in the Grand Mesa field. This but emphasizes the fact that the collections of plants are too meager and obviously incomplete to enable us to reach thoroughly conclusive results, though when fuller collections are obtained, as in the Glenwood Springs area, the resemblance to higher beds is accentuated. 


\section{TERTIARY SYSTEM.}

\section{OHIO CREEK CONGLOMERATE.}

The Mesaverde is the youngest Cretaceous formation known to occur in the Grand Mesa and West Elk Mountain region. The Lewis shale, which overlies this formation elsewhere, is not here represented, nor are there any sedimentary rocks in this region that are now conceded to be of Laramie age. The Mesaverde is separated from the next younger formation by an erosional unconformity, which if correlations are correct must represent all of Lewis and Laramie time. The formation here resting upon the Mesaverde is known as the Ohio Creek conglomerate. It is a conglomeratic sandstone 100 to 200 feet thick, and was first described and named by Eldridge ${ }^{1}$ from the Anthracite-Crested Butte region. It was observed by the present writer in several places but not traced continuously in the western part of the Grand Mesa field. In this field it is best exposed north of Mount Gunnison and in Coal Creek canyon about 10 miles from its type locality on Ohio Creek.

The line of unconformity separating the Ohio Creek conglomerate from the Mesaverde in the Grand Mesa field is more or less sinuous, as shown in Plate VI, $A$. The hollows eroded in the underlying sandstone are filled with coarse sand and pebbles derived from several kinds of igneous and metamorphic rocks, and similar pebbles occur at several higher horizons. The formation is white and contrasts sharply with the overlying Wasatch ("Ruby") formation, which is highly colored. In the Grand Mesa field it does not differ from the formation as described by Eldridge, except that it is thinner and the pebbles are smaller than in the type locality. Its areal distribution is not accurately known. In its type locality it occurs locally, but there is reason to believe that this is due to removal by erosion previous to the deposition of the Wasatch formation and that the conglomerate was once continuous over a wide area. A white conglomeratic sandstone similar to it in general appearance was noted between the Mesaverde and the Wasatch formations in Grand River canyon near Palisades, and Hills ${ }^{2}$ mentions a similar bed farther north near Glenwood Springs.

No organic remains other than fragments of carbonized wood were found in this conglomerate, and no evidence of its geologic age was obtained. Lithologically it is similar to the Arapahoe formation ${ }^{3}$ of the Denver Basin and has the same stratigraphic relation to the underlying coal-bearing rocks that the Arapahoe has to the Laramie.

1 Eldridge, G. H., Anthracite-Crested Butte folio (No. 9), Geol. Atlas U. S., U. S. Geol. Survey, 1894.

2 Hills, R. C., Orographic and structural features of Rocky Mountain geology: Proc. Colorado Sci. Soc., vol. 3,1891, p. 391 .

3 Cross, Whitman, Geology of the Denver Basin in Colorado: Mon. U. S. Geol. Survey, vol. 27, 1896, pp. 206-252, 


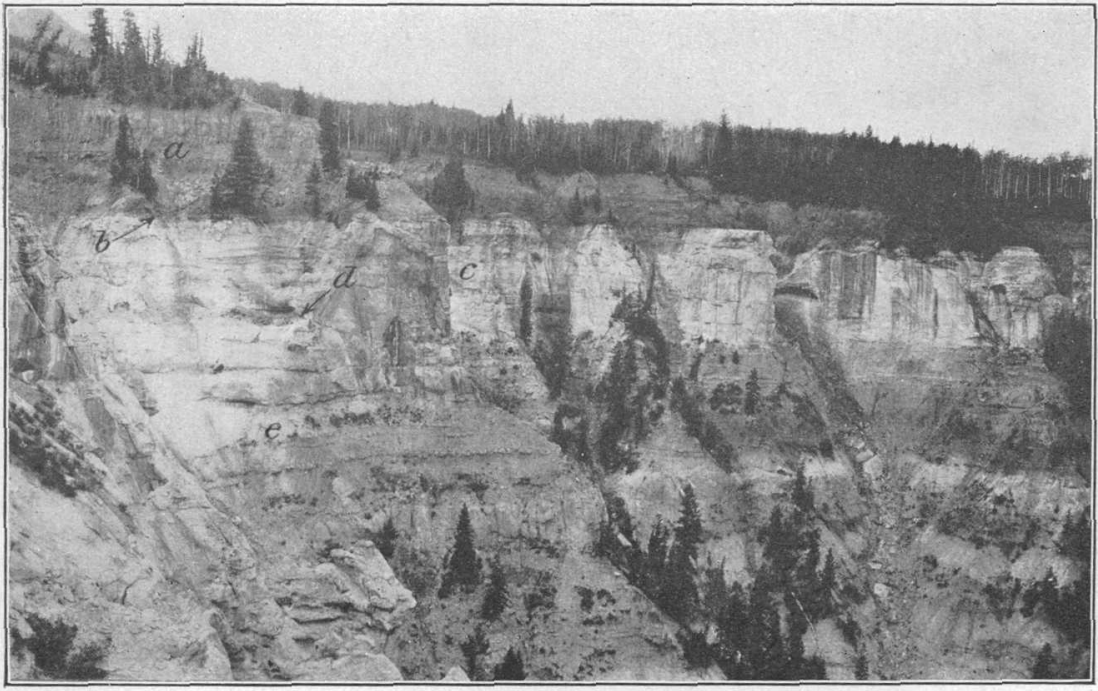

A. EXPOSURE OF ROCKS NORTH OF MOUNT GUNNISON.

Showing the basal conglomerate of the Wasatch ("Ruby") formation $(a)$, the unconformity at the base of the Wasatch $(b)$, the Ohio Creek conglomerate $(c)$, the unconformity at its base $(d)$, and the upper or undifferentiated part of the Mesaverde formation (e). (Scale: The trees are 50 to 75 feet high.)

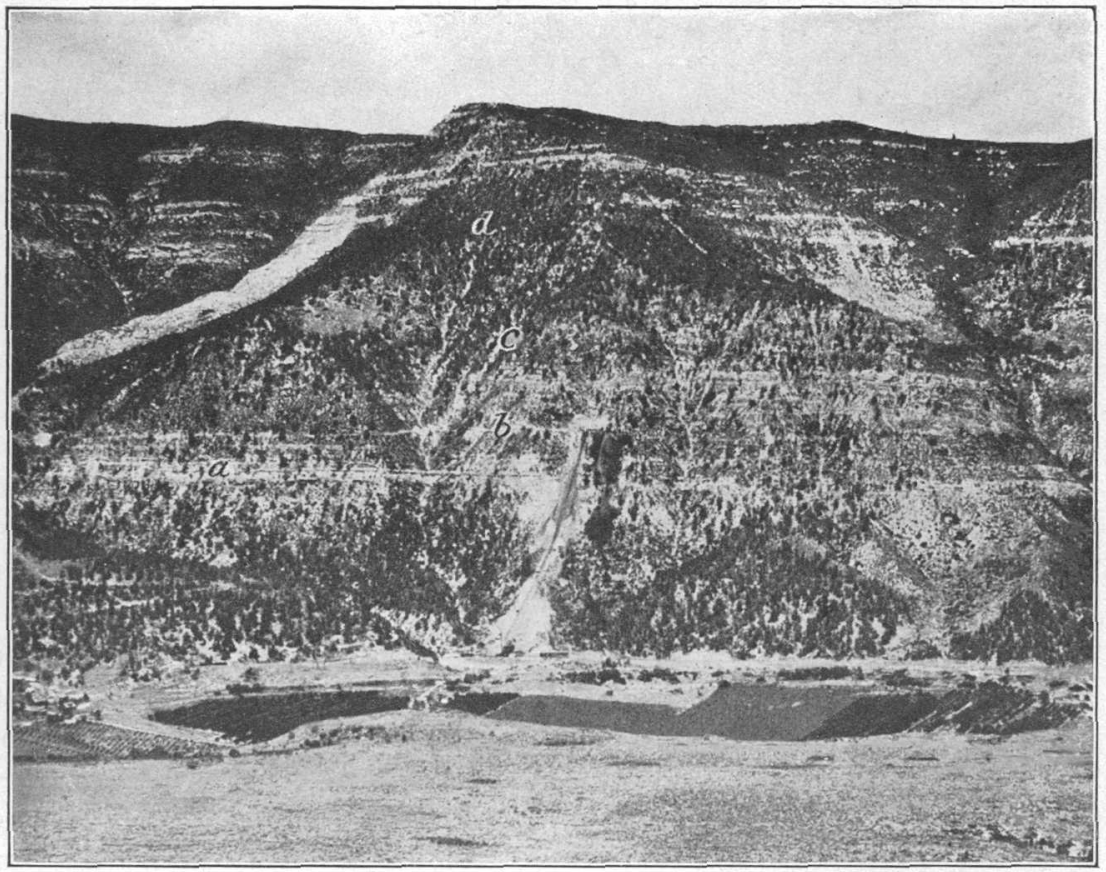

B. NORTH WALL OF GUNNISON CANYON AT BOWIE, COLO

The base of the slope consists of Mancos shale, above which is the Rollins sandstone member of the Mesaverde formation $(a)$, the Bowie shale member of the same formation $(b)$ (the type locality), in which the King mine is located, the Paonia shale member of the Mesaverde formation $(c)$, and the upper or undifferentiated part of the Mesaverde $(d)$. (Scale: The mine is 600 feet above the base of the slope.) 
Hills ${ }^{1}$ assumed that the coal-bearing rocks of the Grand Mesa field are equivalent in age to the Laramie of the Denver Basin and naturally correlated the Ohio Creek conglomerate with the Arapahoe. This correlation was accepted by Eldridge in his description of the Anthracite-Crested Butte fields, in which he refers this conglomerate to the Cretaceous. Nothing was found in the area here described that would invalidate this correlation, but near Rifle, Colo., in sedimentary rocks holding a stratigraphic position similar to that of the Ohio Creek conglomerate, fossil plants supposed to be of Fort Union (Tertiary) age have been found. ${ }^{2}$ The presence there of a formation of Tertiary age between the Mesaverde and the Wasatch formations suggests that the Ohio Creek conglomerate, which is similarly situated, may be of Fort Union age. For this reason the conglomerate that Eldridge and others regarded as Cretaceous is here referred provisionally to the 'Tertiary.

\section{WASATCH ("RUBY") FORMATION.}

The Wasatch ("Ruby") formation, consisting of highly colored conglomerate, sandstone, and shale, lies in some places unconformably upon the Ohio Creek conglomerate and in other places unconformably upon the Mesaverde. It is described by Eldridge ${ }^{3}$ as follows:

Its maximum observed thickness in Mount Owen and Ruby Peak is about 2,500 feet, but it has been extensively eroded and is much thinner elsewhere. It consists of red, purple, and green sandstones and shales, with a few beds of conglomerate made up, for the most part, of débris of various eruptive rơcks. The conglomerates, which appear at numerous horizons, are generally only a few feet in thickness. The basal conglomerate, however, is from 20 to 30 feet thick and consists mainly of chert or quartz pebbles with a few of Archean rocks. The cherts are white, black, or red, and some contain cavities formerly filled by crinoid stems, which were derived originally from Carboniferous rocks and resemble those occurring in the Ohio [Ohio Creek] conglomerate. Igneous material is found with the other in subordinate amount at the base of the conglomerate but predominates toward the top. In the other conglomerates the pebbles are of igneous rocks, but those of quartz and chert are sometimes found. Quartz sand is mixed with that of the igneous rocks throughout the series, increasing in amount in the upper part. The igneous rocks were originally porphyrites and andesites, but the constituent minerals are usually much decomposed, especially the biotites, hornblendes, augites, and magnetites, the hydrated oxide of iron being deposited in the space of the original crystals or in the matrix of the conglomerates, producing purplish or reddish tints in the rock. Where iron-bearing silicates, such as epidote, have been formed, the rock assumes a greenish tint, and where the iron is leached out it becomes almost white. In some of the reddish beds epidote is developed at certain centers, producing green nodular masses. * * * The Ruby beds [Wasatch] are found in best developmentalong the summit and southwestern slopes of Scarp Ridge and of the Ruby Range.

1 Hills, R. C., op. cit., p. 395.

2 Gale, H. S., Coal fields of northwestern Colorado and northeastern Utah: Bull. U. S. Geol. Survey No. 415,1910 , pp. $89-90$.

op. cit. 40642 - Bull. $510-12-4$ 


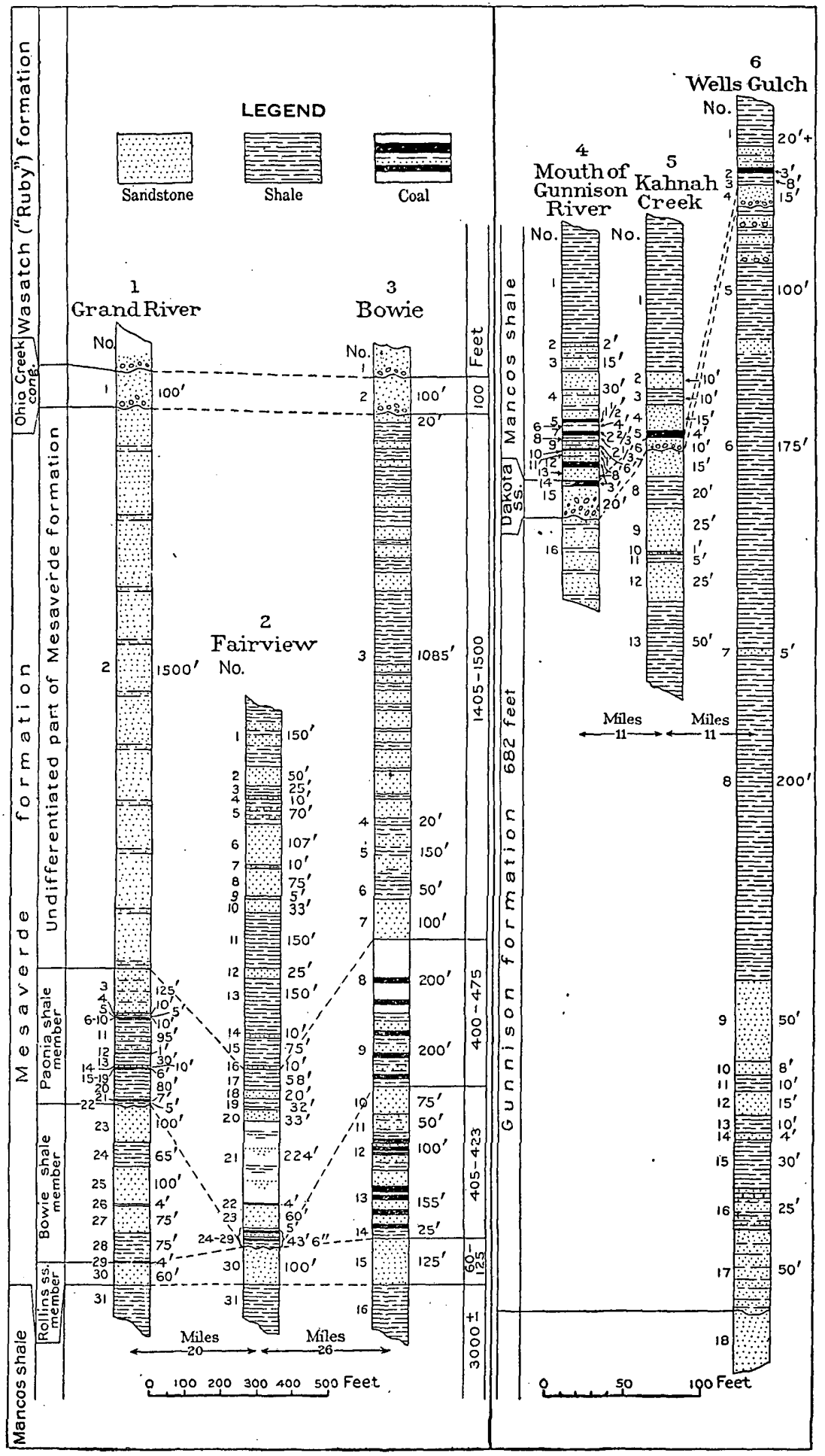

FIGUBE 3.-Columnar sections of formations measured in the Grand Mesa field. 
From the Ruby Range this formation was traced westward throughout the Grand Mesa field. In the eastern part of this field, the beds like those described from Ruby Mountain consist principally of coarse conglomeratic sandstone and sandy shale of dark red color. Toward the west the materials become finer and the colors grow dull and more varied, until at the western end of the field the beds are best described as variegated. Wherever the base was seen in the eastern part of the Grand Mesa field it consists of a conglomerate, which rests upon an eroded surface either of the Ohio Creek conglomerate or of sandstone in the Mesaverde formation and is made up of pebbles of fossiliferous chert, eruptive rock, and a great variety of metamorphic and crystalline igneous rocks as described by Eldridge. Pebble beds were found at several horizons in different parts of the field. Toward the west the basal material becomes finer and the unconformity at the base is not conspicuous.

In the papers just referred to, Hills and Eldridge correlate the "Ruby" with the Denver formation. Eldridge states that the "Ruby" extends westward from Ruby Range and disappears beneath the Wasatch formation. The present investigation, however, shows that his "Ruby" formation is probably identical with that mapped as Wasatch in the Grand Mesa region by the geologists of the Hayden Survey. No fossils were found by Eldridge in the "Ruby" of the Anthracite-Crested Butte region, nor did the writer find any in this region or in the Grand Mesa field, but in the Book Cliffs, west of Grand Mesa, about 35 miles northwest of Palisades, Richardson ${ }^{1}$ found Wasatch fossils in variegated beds that are apparently identical with those of Grand Mesa. Hills" states that the "Ruby" formation extends northward to and beyond Grand River, and H.S. Gale ${ }^{3}$ and A. L. Beekly ${ }^{4}$ have traced a formation that is apparently the same from Coal Basin northward continuously, except for about 15 miles at Axial Basin, into the characteristic Wasatch of southern Wyoming. For these reasons the "Ruby" formation is here referred to the Wasatch (Eocene).

GREEN RIVER FORMATION.

The Green River formation, which overlies the Wasatch, was observed in only a few localities, and the writer can add little regarding it to the information given in the Hayden reports. It outcrops high in Grand Mesa and is covered by basalt that forms the table-like top of the mesa.

\footnotetext{
1 Richardson, G. B., Reconnaissance of the Book Cliffs coal field: Bull. U. S. Geol. Survey No. 371, 1909 , p. 21.

2 Hills, $\dot{R}$. C., Orographic and structural features of Rocky Mountain geology: Proc. Colorado Sci. Soc., vol. 3, 1891, p. 390 .

${ }^{8}$ Gale, H. 6., Coal fields of northwestern Colorado and northeastern Utah: Bull. U. S. Geol. Survey No. 415,1910 .

4 Unpublished report on work done between Grand River and Coal Basin, Colorado.
} 


\section{QUATERNARY SYSTEM.}

Little attention was given to the Quaternary deposits of the Grand Mesa and West Elk Mountain region. They consist of unconsolidated material deposited by streams in the lowlands, mainly in Slate River valley and Ohio Creek valley in the eastern part of the region and along Surface Creek and Gunnison River in the western part, and of morainal material on some of the higher slopes on the West Elk Mountains. In the Grand Mesa field the only material aside from the fluviatile deposits that can be referred to the Quaternary is that which forms the veneer of detritus on the graded slopes.

IGNEOUS ROCKS.

\section{GENERAL, FEATURES.}

The nature of the work on which this report is based was such as to preclude more than an incidental examination of the igneous rocks that occur abundantly in the Grand Mesa and WestElk:Mountain coal fields. However, the igneous rocks of the Anthracite and Crested Butte quadrangles, which constitute a part of this region, have been described by Cross, ${ }^{1}$ and these rocks extend into the areas described in this bulletin lying south and west of the Anthracite quadrangle.

The igneous rocks present four general modes of occurrence. (1) The most prominent are the great laccoliths and the intrusive sheets associated with them. The laccoliths form a remarkable group, the most conspicuous members of which within the area described in this bulletin are Crested Butte, Mount Wheatstone (see Pl. XIII, A, p. 170), Gothic Mountain, Mount Axtell, Mount Beckwith, and Mount Lombard (see Pl. VIII, A, p. 112), Mount Gunnison and The Cliff. (See Pl. IX, $B$, p. 113.) (2) There is an extensive system of dikes the most prominent of which occur in the Ruby Range. (3) Extensive masses of volcanic breccias, tuffs, and semiconglomerates known as West Elk breccia (see Pl. XII, B, p. 146) occur in and around West Elk Peak and cover a large area. (4) Surface lava flows occur in two places, viz: Mount Wilkinson and Grand Mesa.

The intrusive rocks in the area described cut Cretaceous and Tertiary sedimentary rocks. Elsewhere in this general region, according to Cross, the same rock types cut stratified rocks of many older periods, but his conclusion as to the laccoliths and dikes of the Anthracite and Crested Butte quadrangles was that they "are certainly of Tertiary age." The Mount Axtell laccolith and the double laccolith of Mount Beckwith and Mount Lombard were intruded at or near the base of the Wasatch formation, and the dikes of Ruby Range penetrate the entire thickness of this formation. Therefore, these

1 Cross, Whitman, Anthracite-Crested Butte folio (No. 9); Geol. Atlas U. S., U. S. Geol. Survey, 1894, pp. 4-6: See also The laccolitic mountain groups of Colorado, Utah, and Arizona: Fourteenth Ann. Rept, U. S. Geol. Survey, pt. 2, 1894, pp. 157-203. 
igneous rocks must have been intruded into the sedimentary rocks not earlier than the close of the Wasatch.

The surface flows of basalt were much later than the intrusives. The Grand Mesa flow rests on the Green River formation (Eocene). On the other hand, the great amount of degradation that has occurred since the outpouring of the basalts, which has left Grand Mesa standing 5,000 feet above the level of the country south and west of it, indicates that a long time has elapsed since the flows took place. The flows on Mount Wilkinson apparently are younger than those of Grand Mesa. Cross suggests that they may be Pleistocene, but no positive evidence of their age has been found.

The following description of the rocks from the Anthracite and Crested Butte quadrangles has been prepared for this bulletin by Whitman Cross. It is largely a quotation from the AnthraciteCrested Butte folio, with changes in the rock names, which are duly explained. There are also such changes in the sedimentary formation names and in the correlations as are made necessary by the revision of the stratigraphic column adopted for this bulletin.

The chief rock types represented are monzonite porphyry, andesite, and basalt. Granite porphyry is also found among the dikes of the Ruby Range but was not distinguished upon the Anthracite map.

\section{QUARTZ MONZONITE PORPHYRY.}

By far the greater number of the intrusive rocks of the West Elk Mountains may be called quartz monzonite porphyry. They are all holocrystalline porphyritic rocks, which are chemically and mineralogically equivalents of granular quartz monzonite. These rocks were called diorite porphyrite in the Anthracite-Crested Butte folio. The term porphyrite is no longer used in the publications of the United States Geological Survey, and since the folio was issued the term monzonite has come into general use for granular rocks rich in both orthoclase (potash feldspar) and plagioclase (soda-lime feldspar). The rocks here described contain both feldspars in large amount also a considerable percentage of quartz, which may well be denoted in the name.

The numerous porphyry bodies of the Anthracite and Crested Butte quadrangles occur in dikes and in intrusive sheets of various dimensions from a few feet up to 2,000 or 3,000 feet in thickness. Some of the dikes of the Ruby Range are offshoots from larger crosscutting masses of granular monzonite or diorite. In the Crested Butte quadrangle the large porphyry masses forming Crested Butte, Gothic Mountain, and Mount Wheatstone are laccoliths, from which the soft shaly strata that once arched over them, as is illustrated in Plate XII, $A$, page 146, have been entirely eroded, allowing these great uniform masses to be carved into rugged mountains. Contacts 
of the porphyry and the strata beneath are plainly shown at several places on each of these mountains. These contacts are either approximately horizontal or dip slightly under the mass.

These relationships can be clearly seen on the southern slope of Crested Butte above the little dikes shown on the map, on the eastern face of Gothic Mountain above the intrusive sheet, and on Mount Wheatstone at its southern extremity and in the large gulch on its northern slope. On Crested Butte a decided bench runs around the mountain just below the contact line.

The true character of these great rock masses is shown by the smaller mass of the same rock occurring on the ridge between Gothic Mountain and Crested Butte. This is a small laccolith, and a remnant of the strata resting on the eruptive rock and dipping at an angle of about $30^{\circ} \mathrm{NW}$. may be seen at the point nearest Gothic Mountain. The character 'of the large masses is also clearly shown by many bodies intermediate in thickness between the thin sheets and the great laccoliths.

The porphyries of the Anthracite quadrangle occur in crosscutting dikes or in bodies intruded more or less distinctly parallel to the stratification planes of the sedimentary rocks. The latter masses range in size from sheets a few feet in thickness and with considerable lateral extent to huge laccoliths more than 3,000 feet thick. The regularity of many of the sheets is quite surprising in view of the shaly nature of the strata into which they are intruded. Crosscutting from one horizon to another and a splitting of one sheet into two are common features.

The relationship between the thin sheets and the large laccoliths is clearly demonstrated in the mass of Mount Axtell. This large body of quartz monzonite porphyry containing large crystals of orthoclase is injected into the sedimentary series at a horizon just. above the base of the Wasatch formation. There is a thin stratum of the latter formation between the Mesaverde and the base of the porphyry mass as seen at several localities about Mount Axtell; namely, at its eastern base, on the western border south of Ohio Pass, and on its north side. From the contact east of Mount Axtell to the summit, more than 1,000 feet of the porphyry is shown, and its thickness at this point was once still greater. Toward the north in the region east of Irwin, this mass thins out and passes as a sheet between the strata of the Wasatch formation. On the northern cliff of Scarp Ridge and in the basins on the southern slope, the sheet appears as a very regular body 10 to 30 feet in thickness and faulted with the inclosing strata. In passing into a thin sheet the rock loses its large orthoclase crystals, though they do not entirely disappear until the thinnest parts of the body are reached. Increasing density and fineness of grain also characterize the passage to the thin sheet. 
The character of the larger porphyry masses is also indicated by the laccoliths that are revealed by the canyons of Cliff and Anthracite creeks. At the tops of the canyon walls the strata are seen resting on the porphyry and curving down at the ends of the exposures. On the eastern, northern, and western borders of the Mount Beckwith laccolith, the Wasatch beds dip away from the eruptive mass. On the north of the Anthracite Range, porphyry disappears beneath the Mesaverde strata, and on the west the beds are steeply upturned against it.

Where so many large bodies are injected at short distances from each other into shaly and loosely consolidated strata it is manifestly impossible for the bẹds to assume the regular position with respect to each eruptive mass that they might occupy in regard to the typical laccolith. The rocks differ sufficiently to indicate that the bodies were not contemporaneous, and a later injection must undoubtedly have irregular contacts with the beds on the side toward a neighboring laccolith. The huge talus slopes covering contacts on the more precipitous faces of the laccolithic bodies make observations impossible on the line of some of these apparent ruptures.

Storm Ridge is a mass of fine-grained porphyry exhibiting few large orthoclase crystals. It is for the most part surrounded by the volcanic breccias of the West Elk Peak. The outline of this mass on the geologic map of the Anthracite-Crested Butte folio is but approximately correct, as its former relationship to inclosing strata could not be determined, owing to erosion and to the great talus slopes, which conceal contacts.

To the descriptions by Cross may be added some statements concerning masses not examined by him. The Storm Ridge mass extends south of the Anthracite quadrangle and apparently connects with an intrusive base of West Elk Peak, but its outlines were not determined. The laccolith in Cliff Canyon, which Cross refers to, is the one described elsewhere in this bulletin (p. 64), and which, because of its conspicuous occurrence in this canyon, has been called "The Cliff." From a feather edge at the mouth of Cliff Creek it increases in thickness upstream to 1,000 feet or more and apparently connects under cover with the Storm Ridge mass, as indicated in the structure sections of Plate I (in pocket).

The laccolithic porphyry mass of Mount Lombard lies west of the area described by Cross. It is connected with the mass of Mount Beckwith and like it was intruded near the base of the Wasatch formation. Its contact with the underlying sedimentary rocks wrs not seen, but the top of the plateau upon which it rests (see Pl. VIII. $A$, p. 112) consists of Ohio Creek conglomerate, above which in most places occurs the basal conglomerate of the Wasatch formation. 
These beds were not disturbed by the intrusion and apparently extend under the laccolithic mass. On the other hand north of the mountain, the Wasatch beds above the basal conglomerate are upturned. This laccolith is eroded to a sharp point, which rises about 3,500 feet above the base of the porphyry mass. Obviously the laccolith was originally more than 3,500 feet thick.

Mount Gunnison also is a laccolithic mass of monzonite porphyry, which was intruded into the Mancos shale. A thickness of about 5,000 feet of the intrusive rock is exposed in Coal Creek canyon, but the base of the mass was not found. This mountain constitutes the largest body of intrusive rock within the area described in this bulletin, but it is only a part of a much larger mass, most of which lies west of the Coal Creek district beyond the area here described.

\section{WEST ELK BRECCIA.}

The following description of the West Elk breccia. by Cross, is quoted from the Anthracite-Crested Butte folio:

In the southwestern corner of the Anthracite quadrangle appears the northern end of a great volcanic breccia, which forms West Elk Peak and, as shown by the Hayden map, extends southward to the Gunnison River. In West Elk Peak and outlying ridges, some of which extend into the Anthracite quadrangle, this volcanic material causes very wild and rugged mountain shapes, and isolated remains often bear fantastic resemblances to towers, castles, or cathedral spires. One of the most striking of these, "The Castle," stands on a rampart ridge between the forks of Castle Creek. [See P1. XII, B, p. 146.] in

The bedded arrangement of the material as seen in cliff faces is very marked, but it is largely due to an alternation of coarse breccia with finer ash or tuff and in the places observed is to be compared with the stratification common in products of volcanic vents or produced by surface agencies rather than with that of sedimentation. The location of the vent or vents from which this material was ejected is unknown, but it must be south or southwest of the Anthracite quadrangle [in the vicinity of West Elk Peak].

The massive breccia is seen at the head of Castle Creek, on Swampy Pass and above it on the cliff-like face of the Anthracite Range. At various places on Pass and Castle creeks are remnants of dark breccia, but many other exposures are of crumbling tuff and soft arenaceous material carrying some small eruptive fragments. The growth of timber and the débris covering slopes near Storm Ridge and the Anthracite Range conceal so much of the formation that the actual relationships to the Cretaceous have not been accurately worked out. It may be that the lower part of what is mapped as breccia may be more properly considered as a sedimentary formation. The observations made do not permit a distinction between such material and the breccia.

In the ridges south of Storm Ridge the breccias are best seen. Here they form loosely consolidated banks alternating with finer grained ash or tuff beds, containing some coarse fragments. None of the breccias seen are very massive. The fragments are prevailingly dark, fresh-looking andesitic lavas of various textures. Microscopical examination of the fragments collected shows that hornblende andesite predominates. Augite andesite is also abundant. No quartzose varieties were seen and no basalt. The series is overlain by rhyolitic lavas near the Gunnison River, as ascertained by Dr. Peale during the Hayden survey. 
BASALT.

According to Cross, the capping sheet of Mount Wilkinson (Crested Butte quadrangle) consists of several thin flows of a typical black basaltic lava. These show scoriaceous and vesicular outer zones and dense, dark-gray or black rock within. The thickness of the basaltic capping now remaining ranges from 50 to 200 feet. The basalt rests upon an eroded surface of Mesaverde strata. Between different flows there is commonly some reddish volcanic ash, and below the first flow at the northern point of the mountain is a remnant of a basaltic tuff filled with bombs, or rounded ejected fragments. This formation is 20 feet thick and indicates the existence of a true volcanic vent at no great distance, but the location of this vent is not known.

Relatively little is known of the basalt flows of Grand Mesa. With the exception of two localities they were seen in place only from a distance. The lava cap of the mesa is several hundreds of feet thick and is made up of many separate flows. Judging from the character of the débris that covers the sides of the mesa, a considerable part of the lava cap consists of tuff and breccia. The rock is more or less magnetic, and in many places blocks of it so strongly affect the magnetic needle that compass observations taken near them can not be relied upon.

\section{GEOLOGIC STRUCTURE.}

\section{RELATION OF THE GRAND MESA AND WEST ELK MOUNTAIN COAL FIELDS TO THE UINTA BASIN.}

The Grand Mesa and West Elk Mountain coal fields form parts of an extensive structural basin situated in western Colorado and eastern Utah, an outline of which is shown in figure 1, on page 7 . The coal outcropping around the rim of the basin has been described in several publications of the United States Geological Survey. ${ }^{1}$ This paper has to do only with the part of the southern rim that lies east of Grand River and with the extreme southeastern point of the syncline in Gunnison County.

The coal-bearing rocks of the Grand Mesa field incline gently toward the axis of the syncline, the average dip being about $22^{\circ}$. From their outcrop in the south rim of Grand Mesa the coal beds

1 Eldridge, G. H., Anthracite-Crested Butte folio (No. 9), Geol. Atlas U. S., U. S. Geol. Survey, 1894. Taff, J. A., Book Cliffs coal field, Utah, west of Green River: Bull. U. S. Geol. Survey No. 285, 1906, pp. 289-302; The Pleasant Valley coal district, Carbon and Emory counties, Utah: Bull. U. S. Geol. Survey No. 316, 1907, pp. 338-358. Richardson, G. B., The Book Cliffs coal field between Grand River, Colo. and Sunnyside, Utah: Bull. U. S. Geol. Survey No. 316, 1907, pp. 302-320; Reconnaissance of the Book Cliffs coal field between Grand River, Colo., and Sunnyside, Utah: Bull. U. S. Geol. Survey No. 371, 1909. Gale, H. S., Coal fields of the Danforth Hills and Grand Hogback in northwestern Colorado: Bull. U. S. Geol. Survey No. 316, 1907, pp. 264-301; Coal fields of northwestern Colorado and northeastern Utah. Bull. U. S. Geol. Survey No. 341, 1909, pp. 283-315, Lee, W. T., The Grand Mesa coal field. Colorado, Bull. U. S. Geol. Survey No. 341, 1909, pp. 316-334. 
apparently extend continuously under the younger rocks of Uinta Basin and reappear with opposite dip in the Grand Hogback along the eastern and northern rim. In the fields southeast of Grand Mesa, where the sedimentary rocks have been disturbed by the intrusion of laccolithic masses, the beds are inclined in various directions and their relation to the Uinta Basin is not so obvious as that of the beds in the Grand Mesa field. However, they were once continuous with the beds of Grand Mesa and are properly included in the Uinta Basin.

The complicated structure in the Anthracite-Crested Butte region has been described by Eldridge in Geologic Folio No. 9. This folio is now out of print and his descriptions, so far as they apply to the areas here described, are quoted in full.

\section{ANTHRACITE QUADRANGLE.}

The area represented on the Anthracite sheet is a region of gently folded, sedimentary beds of Cretaceous age, through which an immense number of eruptive bodies in the form of laccoliths and dikes have been intruded producing local deformation and considerable faulting with both contact and regional metamorphism.

The broader underlying features of the structure can be traced to the effects of two important mountain-raising elevations just beyond the limits of the area mappedthe Treasury Mountain dome or quaquaversal, and the fault-fold of the Elk Mountains.

Treasury Mountain, whose uplift has had the most widespread effect upon the structure of the region, is a dome-shaped elevation lying north of Slate Peak about 2 miles beyond the boundaries of the map. It consists of a central mass of Archean rocks, from which-the sedimentary beds in rudely concentric circles dip away at angles which decrease with distance from the center.

The axis of the Elk Mountain fold, whose structure is shown on the Crested Butte sheet, runs in a northwest direction about 4 miles northeast of Gothic Mountain. The effect of this uplift in the eastern part of the Anthracite sheet is a slight fold of the sedimentary rocks producing but little modification of the regular dip from Treasury Mountain. The Treasury Mountain uplift is an older feature in the orographic history of the region than the Elk Mountain fold, and the intrusion of the various laccoliths and dikes is more recent than either, but in the resulting structure it is not always possible to differentiate the effect3 of the respective movements.

The present topographical structure of the region is the result of long continued erosion, which has acted most rapidly in the softer and less resisting rocks, leaving the great dikes and laccolithic masses and the indurated sedimentary beds in mountains or ridges. But the present stream beds do not in all cases avoid these more resisting masses of rock; in some places, such as lower Anthracite and Coal creeks, the streams cut into or across them, having originally assumed their courses in the softer beds which once completely covered the eruptive masses. It is not possible to make more than an approximate estimate of the amount of post-Cretaceous erosion, for the thickness of the beds which once covered the region can not be determined. Sediments at least 6,000 feet thick have been carried away from certain parts of it, and perhaps nearly double this amount has been removed.

Some description of the more important geological features is necessary to supplement the facts graphically set forth on the various maps.

Northeastern region.-The arc of a circle having a radius of about 6 miles, drawn from Treasury Mountain as a center and including the Slate River valley to a little below Pittsburg and the mountain ridges on either side as well as those bounding 
the head of Dark Canyon [west of Augusta Mountain] would inclose the area in which the influence of the Treasury Mountain uplift is most distinctly shown. Within this area the beds dip away from the central uplift at an angle of $15^{\circ}$ on the periphery, which increases to $25^{\circ}$ and in some places to $45^{\circ}$ near the center. In strike they vary from a little north of east through east and west to a little north of west. The steeper angles of dip are found in Cinnamon Mountain, where a large mass of eruptive diorite is thrust into the sedimentary beds. Outside of this area, to the south and southwest, prevailing southerly and southwesterly dips continue with generally decreasing angles as far as the valleys of Coal and Anthracite creeks, beyond which southward the strata rise toward the adjoining laccolithic bodies. * * *

On the eastern slopes of Mount Baldy, around Gothic Mountain, in the upper part of Washington Gulch, in Anthracite Mesa, and in the ridges bordering Slate River valley on the southwest are secondary flexures with axes parallel to the axis of the Elk Mountain fold, whose influence on the present topography is seen in the general northwest trend of the valleys and intervening ridges in this part of the region.

The whole region is traversed by an immense number of eruptive dikes and fault planes, comparatively few of which could be represented on the map. Their strikes have such varying directions that it is difficult to detect any regular system, but the greater number appear to follow the two trends of northeast and north by east, which are radial respectively with the Elk Mountain and Treasury Mountain uplifts, or a trend which is the resultant of these two. The planes of the faults are usually vertical and the displacement is slight, being rarely over 100 feet. In Scarp ridge, where conditions are most favorable for the detection and measurement of these faults, the displacement is usually an upthrow to the west or north. That the faulting was not all synchronous is shown by the fact that the fault planes are often broken by later faults, especially by slip faults, or those whose planes conform to the bedding. The latter were observed in many parts of the region, notably under Gothic Mountain laccolith, which has been thereby moved slightly westward on the underlying Pierre shales [Mancos shale]; also at the base of the Laramie [Mesaverde] in Dippold basin, and at various points in Scarp Ridge. As displacements along a bedding plane produce no discrepancy in the succession of beds, such faults are necessarily less easy to detect than those which cut across the bedding planes.

Anthracite Mesa.-The structure of this little ridge is important because of the valuable beds of anthracite coal which it contains. The coal basin, which occupies the higher portion of the nearly flat-topped ridge, formed part of the northwestern member of a syncline, the greater part of whose trough has been carried away by the erosion of Slate Valley. On the northeastern edge of the basin, the strata have a dip of $22^{\circ}$ to $26^{\circ} \mathrm{SW}$., which declines to $5^{\circ}$ or less in its southwestern limb, the average strike being about $\mathrm{N} .30^{\circ} \mathrm{W}$., or a little nearer north than the trend of the ridge, so that the steeper dips of the northeast side prevail in the southern end, where, through erosion of the Laramie [Mesaverde] beds, the Fox Hills [Rollins] sandstone is exposed. A multitude of small faults, generally with a displacement of but a few feet, cross the ridge in a northeast direction. There is also evidence of slip faulting in the character of the upper and lower layers of the main coal seam, which are crushed into angular fragments with striated faces for a distance of 3 to 5 inches from either surface.

Ruby Range.-The uplift of the Ruby Range, which is topographically the most important and striking feature of the area mapped on the Anthracite sheet, has had little or no effect upon the structural position of the sedimentary beds involved. The latter maintain throughout the uplift a comparatively regular and uniform dip to the south and west, at an angle which grows gradually less toward its southern end. Although the sedimentary beds are extensively fractured, and in some cases slightly 
disturbed at the immediate contact with the larger bodies of eruptive rock that have cut through them, the amount of the displacement or deformation is comparatively insignificant. The superior resistance to erosion offered by the great number of eruptive dikes and by the adjacent sedimentary beds indurated by the metamorphism attendant upon their eruption is the cause of the existence of this remarkably narrow and precipitous mountain ridge, which in a linear extent of less than 7 miles has as many peaks of nearly or quite 13,000 feet elevation. Metamorphism has in many cases so altered both sedimentary and eruptive rocks as to make them almost indistinguishable; and among the altered sedimentary rocks, where the original lithological characters as well as the fossil contents of the beds are in a great measure obliterated, the tracing of geological horizons requires the greatest care and circumspection on the part of the observer. The beds which are most readily recognizable and hence of greatest value for this purpose are the conglomerates, such as the conglomerate at the base of the Ruby beds [Wasatch formation], and the coarser and more massive sandstones of the Laramie and Fox Hills [Mesaverde] horizons. These generally form the beds of the principal glacial amphitheaters, or so-called "basins," which are a characteristic feature of the topography of the region.

The metamorphic action, which is directly traceable to the influence of a contiguous body of eruptive rock, appears to have extended but a ohort distance in directions parallel with the stratification planes and much farther across the bedding. In other words, more widespread alteration has resulted from the vicinity of intrusive sheets that occupy a position parallel with the stratification than from dikes that cut across it.

Southern area.-In the southern third of the Anthracite area there is a general rise of the sedimentary beds toward the south. A certain portion of this rise is directly traceable to the influence of the various laccolithic intrusions; it is known, however, that there is a general slight rise of the Mesozoic beds toward the Archean rocks that are exposed along the Gunnison River and its tributaries, 15 to 20 miles south and east of the present area, to which the northwest dips beyond the laccolithic bodies in the southeastern corner of this area are attributable.

Between Marcellini and Mount Beckwith the Ruby beds [Wasatch] lie in a broad syncline whose axis is about 2 miles south of the former peak. In the southern member the strata rise with gradually increasing angle, which ${ }^{\circ}$ reaches $25^{\circ}$ at the immediate flanks of the latter. Mount Beckwith is a double laccolith, *** [intruded at the top of the Mesaverde], and in the reentrant angle between the two laccoliths the strata are compressed into a northward-pitching syncline and are upturned at an angle of $45^{\circ}$ against the flanks of either laccolith. * * * South of Mount Beckwith, along Cliff Creek, the strata occupy a comparatively undisturbed position, lying either horizontal or having a dip of $5^{\circ}$ to the north or northwest.

The intrusion of the igneous rocks of the Anthracite Range has had more disturbing influence on the sedimentary beds along its northern flank than that of any other of the laccolithic bodies in the present area. This may be ascribed in part to the fact that several intrusive sheets, probably off-shoots from the central mass and in one case reaching 500 feet in thickness, have been forced in between the strata. Erosion has entirely removed the Ruby beds [Wasatch formation] from the slopes of the range toward Anthracite Creek, and also a portion of the Laramie beds [Mesaverde formation], down to the coal measures. At a few points the tops of the Fox Hills formation [Rollins sandstone] are exposed. The general inclination of these beds is from $15^{\circ}$ to $25^{\circ}$, steepening near the eruptive body and shallowing toward Anthracite Creek, which occupies approximately the axis of the syncline. Beyond it the dip changes quite abruptly to $5^{\circ}$ and $10^{\circ}$ south and west.

The strike of the beds along the northern flank of the range is N. $15^{\circ}$ to $25^{\circ} \mathrm{E}$., becoming nearly northeast at the western extremity of the range, where the strata are upturned at $60^{\circ}$ to $70^{\circ}$ against the laccolith. Between its western end and Beckwith Pass, this steep dip changes abruptly to a horizontal position of the beds. 
On the south flanks of the Anthracite laccolith the sedimentary beds are for the most part buried beneath the talus slopes of the West Elk breccia, but the evidence that could be obtained tends to show that they are comparatively undisturbed.

The topographical basin at the head of Anthracite Creek, included between the slopes of the Ruby Range, Scarp Ridge, Mount Axtell, and the Anthracite Range, corresponds approximately to a geological basin or syncline, whose beds dip in general toward the center from the north, east, and south and include a number of minor folds. It is thus a sort of center of structural disturbance, and in the vicinity of Irwin the strata are broken by an intricate network of small faults, many of which are mineralized and constitute the veins of rich silver minerals for which the district is noted. Only a few of the more extensive and prominent faults have been indicated on the map.

The Mount Axtell laccolith differs from the others thus far mentioned in that the adjacent sedimentary strata have apparently not been disturbed by it, and furthermore, in that to the north it passes into a comparatively thin intrusive sheet which is folded with the inclosing sedimentary strata. The absence of deformed strata around it may be due to the fact that its greatest horizontal extension is at a relatively higher geological horizon (here the contact between the Laramie [Mesaverde] and the Ruby [Wasatch] formations) than those of the other laccoliths, and therefore the strata which were domed úp by its intrusion have been entirely eroded away.

The bed of Coal Creek, which crosses the northern slopes of the laccolith where it passes from the state of laccolithic body into that of intrusive sheet, occupies, as has already been stated, approximately the axis of a synclinal basin. On the southern slopes of Scarp Ridge the underlying sedimentary beds and the lower surface of the eruptive sheet dip $23^{\circ} \mathrm{SSE}$., while the upper surface of the latter dips $12^{\circ} \mathrm{ESE}$., showing a thickening of the latter to the westward. The axis of the syncline, which has a general trend N. $30^{\circ}$ E., crosses Coal Creek near the bend a few miles above the town of Crested Butte. Southwest of this, around the laccolith of Mount Wheatstone, * * * an average dip of $8^{\circ}$ to $10^{\circ} \mathrm{NW}$. is maintained interrupted only by a few minor flexüres.

The Wheatstone laccolith, so far as can be observed, has not disturbed the strata at present in contact. with it to any considerable extent, though they are somewhat fractured on its southwestern flanks along upper Carbon Creek. Its base sometimes follows a stratigraphic plane and sometimes cuts across several hundred feet of strata at a low angle.

The intrusion of the Mount Carbon laccolith has exerted considerable disturbing force on the adjoining sedimentary beds, especially on its western side. Along the eastern side of the upper Ohio Creek valley the Ohio [Ohio Creek] and Laramie beds [Mesaverde] are upturned against it at $45^{\circ}$ and show some secondary folding and faults but shallow in dip to $5^{\circ}$ on the western side of the valley. They also show a tendency to wrap around it, changing in strike from $25^{\circ} \mathrm{NW}$. on the southwest side to $30^{\circ} \mathrm{NE}$. on the northwest slope. To the northeast and east the sedimentary beds appear to retain a normal dip to the north and west with a strike to the east and northeast, the eruptive mass apparently cutting across the ends of the strata without producing any considerable deformation, though the immediate contact is rarely to be seen.

On the south, in the area between Ohio and Carbon creeks, where in the vicinity of Baldwin [locality No. 95] considerable coal mining has been done, the Laramie beds [Mesaverde] are compressed into several parallel folds with an axial trend of N. $50^{\circ}$ to $80^{\circ} \mathrm{E}$. The two anticlines observed have gentle dips except at one point in the northern fold, where a northerly dip of $55^{\circ}$ was observed. In an east and west direction they apparently do not extend much beyond the bounding valleys.

Downstream, to the south and east, the lower Cretaceous horizons soon appear from beneath the Laramie beds [Mesaverde] with a gentle dip to the northwest. 
The Laramie measures [Mesaverde] in the vicinity of Mount Carbon are thinner than in any other part of the field, a boring near the end of the railway in Ohio Creek valley showing 650 to 900 feet of Laramie [Mesaverde] strata with 200 feet of overlying Ohio [Ohio Creek] beds. There may have been a less thickness of Laramie beds [Mesaverde] originally deposited here than in the portion of the area nearer the mountains from which the sediments were derived, but inasmuch as the coal measures show no decided change in thickness, it is more probable that the variation is mainly due to erosion prior to the deposition of the Ohio [Ohio Creek] and Ruby beds [Wasatch].

To the west of Mount Carbon and south of the Anthracite Range and Mount Beckwith, the greater part of the area is occupied by the West Elk formation, which apparently rests unconformably upon the eroded surfaces of the Ohio [Ohio Creek], Ruby [Wasatch], and Laramie [Mesaverde] formations, and possibly also of the laccolithic bodies, though owing to the general covering of débris its contact relations can not be distinctly determined. The bedding planes of this formation generally occupy a horizontal position but display a few gentle and unimportant flexures. In the area west of Storm Ridge there is a general dip of $5^{\circ} \mathrm{NW}$. toward Cliff Creek.

\section{CRESTED BUTTE QUADRANGLE.}

The area represented on the Crested Butte sheet is divided by the valleys of East and Slate rivers, which cross it diagonally from northwest to south, into two unequal portions, which are strongly contrasted in geological structure. Both are mountainous regions, but in the one case the mountains are almost entirely the result of cutting down by erosion, whereas in the other they result from uplift and erosion combined.

In the smaller, southwestern area the sedimentary strata still occupy an approximately horizontal position, the higher peaks resulting from the greater resistance to erosion offered by masses of eruptive rocks intruded between the beds without greatly disturbing them, and the present surface of this area is covered by rocks of more recent age than the Dakota formation.

The eastern area [just east of the area included in the accompanying map, Pl. I, in pocket] was originally uplifted to a much greater elevation, but erosion has eaten into it more deeply, so that although the resulting mountain forms are only 1,000 feet higher on the average than those of the southwestern region, the present surface is mainly occupied by Paleozoic or older rocks.

This area forms a part of the broad Elk Mountain uplift, which has a general northnorthwest trend, nearly parallel with the western flanks of the older Sawatch uplift, and appears to have been forced into its present position by compression against the Archean buttress of the Sawatch. This compression has been intensified by the intrusion of immense masses of diorite, which, instead of welling up and spreading out gently between the strata, were forced violently into and across them, catching up immense fragments of the sedimentary beds within their mass, and pushing adjoining portions into reversed folds and faults.

The general facts of the.structure are represented on the areal and structural maps, but some detailed description of the geological conditions prevailing in different portions of the area will facilitate their comprehension.

Southwestern area.-The basalt cap of Mount Wilkinson rests on an eroded surface of Laramie and Montana beds [Mesaverde and Mancos] dipping gently north westward, so that 100 to 200 feet of the Laramie [Mesaverde] is exposed beneath the northwestern extremity of the basalt sheet, but it does not appear along the southeastern side. The basalt flowed over an uneven surface, and on its southern face there lies between it and a thin sandstone forming the lowest bed of the Laramie [Mesaverde] a deposit of coarse gravel, containing rolled pebbles of nearly all the sedimentary and eruptive rocks to the north, including the Archean. This gravel is probably the relic of an ancient stream bed or morainal ridge. 
The whole Montana formation [upper part of Mancos shale] is well exposed on the eastern slope of Mount Wilkinson, with the Niobrara limestone at its base along Slate River valley. The Laramie beds [Mesaverde] form its northwestern slope and reach their maximum thickness in this region along Carbon Creek. These beds all dip gently northwestward from $5^{\circ}$ to $15^{\circ}$ and their position is not visibly affected by the Mount Wheatstone laccolith. On the northern flanks of Mount Wheatstone in Gibson Ridge, the Laramie [Mesaverde] strata appear dipping $8^{\circ}$ to $12^{\circ} \mathrm{NNW}$. and are capped by a small patch of the Ohio formation [Ohio Creek conglomerate].

A modification of this statement is rendered necessary by later investigation. On the north slope of Mount Wheatstone at localities Nos. 113 and 114 of the accompanying map, the Mesaverde rocks are upturned upon the flanks of the laccolith, and from these localities east and south to locality No. 110 no Mesaverde beds were found. They were apparently lifted by the igneous rock that was intruded below the horizon of the coal beds and they have since been eroded away. North of locality No. 110 the intrusive rock broke upward åcross the strata, leaving a thickness of about 300 feet of Mesaverde under it. Eldridge continues:

In the area between Slate and East rivers around the great laccoliths of Crested Butte and Gothic Mountain, the Pierre beds [upper part of Mancos] of the Montana formation occupy comparatively undisturbed positions, being either horizontal or dipping $2^{\circ}$ to $5^{\circ} \mathrm{SW}$. The strata are altered only at the immediate contact with the eruptive bodies. Some evidence of horizontal displacement is observed in this region, especially at the base of Gothic Mountain, where the porphyry rests on the clay shales. In the point of the ridge between Washington Gulch and Slate River the beds are locally disturbed and the Fox Hills sandstone [Rollins] dips $25^{\circ} \mathrm{SW}$., striking northwest with the trend of the ridge. Meridian Lake, on the east slope of this ridge, occupies a peculiarly narrow, strike valley, which was formed in the clays below this sandstone either by faulting or by glacial erosion. It has no normal inlet or outlet, its overflow escaping through a narrow notch on its eastern bank.

\section{GRAND MESA FIELD.}

The sedimentary rocks in the ${ }^{\circ}$ Coal Creek district dip toward the north. In the northern part of the district the dip is regular, but in the southern part the rocks have been thrown into irregular flexures and the dips are variable in degree and in direction. Toward the south the formations rise on the flanks of the broad uplift that culminates in West Elk Peak a short distance south of the area represented on the accompanying map. They were eroded previous to the formation of the West Elk breccia, which rests on the eroded edges of all formations from Mancos to Ohio Creek, thus duplicating in the Coal Creek district the conditions existing in the southern part of the Mount Carbon field.

The continuity of the sedimentary formations is interrupted west of Coal Creek by the intrusive mass of Mount Gunnison. This laccolith apparently was intruded into the Mancos shale and either upturned or broke through the Mesaverde rocks, remnants of which 
carried up by the igneous material are found high in the mountain. North, east, and south of the mountain they are upturned on its flanks and dip away from it at angles in some places as high as $80^{\circ}$.

East of Coal Creek the structure has been complicated by the intrusion of igneous rock at two horizons. The western lobe of the Mount Beckwith laccolith, which culminates in Mount Lombard, was intruded above the Mesaverde formation and seems not to have disturbed the rocks of this formation nor to have exerted any notable influence upon them. (See Pl. VIII, $A$, p. 112.) The other horizon at which the igneous rock was intruded is about midway of the Mesaverde formation. In Cliff Creek canyon this intrusion appears in the form of a sheet 1,000 feet or more in thickness, which thins toward the west and disappears near the mouth of Cliff Creek, as shown in Plate VIII, $A$, page 112. This sheet thickens toward the south to about 1,000 feet in the ridge south of Cliff Creek, where it forms bold cliffs, one of which is.shown in Plate IX, $B$, page 113. Toward the east the thickness increases rapidly to the places where the sheet disappears beneath the younger rocks. It is probable that the cliff is the outer edge of a laccolith that has not yet been uncovered by erosion. There are some reasons for believing that it is connected with the Mount Lombard and the Storm Ridge intrusions, as shown in the structural sections on Plate I, but it may be independent of them.

Except in the Coal Creek district, the Grand Mesa field is comparatively free from faults and folds, and the flexures are slight. Few displacements that interfere with mining operations have been reported from the mines, and no faults worthy of cognizance, were observed in the cliffs near the outcrop of the coal beds. In the Mancos shale beyond the outcrop of the coal, faulting has occurred in some places, but the massive character of the shale made it impossible to determine the extent of the displacements. However, east of Rollins mine (locality No. 19) the coal-bearing sandstones have been faulted down in one place several hundred feet into the shale, and the fault-line can be followed for a mile or more. Faults were observed also south of Fairview mine (locality No. 20), and dips as high as $55^{\circ}$ were measured, but apparently the disturbances are local and unimportant as regards the development of the coal field. The only movement of consequence that has affected the coal-bearing rocks, aside from that which caused the general tilting of the region, is one that has raised the beds east of Surface Creek about 400 feet higher than the corresponding beds on the west. The difference in altitude was shown by aneroid readings and is subject to correction. The floor of the valley is covered with débris, and it was not possible to determine whether this difference is due to a fault or to a flexure. The probability of its being due to a flexure 
is suggested by the monoclinal termination of the Mesa Inclinado 10 miles south, at the mouth of Black Canyon, where the Dakota and Gunnison formations turn sharply downward and disappear beneath the surface.

The coal beds and their associated rocks are locally upturned at the outcrop and dip $5^{\circ}$ to $8^{\circ}$ or more toward the mesa, flattening to $2 \frac{1}{2}^{\circ}$ in a distance ranging from a few hundred feet to a quarter of a mile. The cause of the upturning is not certainly known, although the following hypotheses have been advanced in explanation of it: (1) The upturned parts may be remnants of eroded anticlines, monoclines, or domes, but this explanation is apparently invalidated by their dipping only toward the mesa and practically at right angles to the outcrop. In no place were beds noted dipping away from the mesa, as would be expected in case they had assumed their present attitude previous to the time of their exposure by erosion. (2) The second hypothesis is that the upturning is due to the weathering of the exposed strata combined with the relief of pressure as the superincumbent rocks were eroded away. This suggestion finds support in the observation that the rocks are generally most steeply upturned in the projecting points of the mesa. On the other hand, it is not certain that the relief of pressure would have any influence on the inelastic rocks, or that the shale underlying the beds in which the upturning is most conspicuous would expand on exposure to the weather. It is possible that the hydration and carbonation of the rocks when they are exposed in the cliffs would cause them to swell and in this way satisfactorily account for the upturning of the beds at the outcrop, but a quantitative measure of this process is difficult to obtain.

\section{COAL.}

\section{STRATIGRAPHIC RELATIONS AND AREAL DISTRIBUTION OF COAL-BEARING ROCKS.}

COAL IN THE MANCOS SHALE.

The lowest coal beds in the Grand Mesa field occur in the zone of transitional rocks intervening between the typical Mancos shale and the Dakota sandstone and outcrop along Gunnison River. They occur more or less continuously from Grand Junction to Delta and again near the mouth of Black Canyon east of Delta, where, according to C. E. Siebenthal, ${ }^{1}$ they are found in the north wall of the canyon for a distance of about 7 miles. The beds dip gently toward the northeast and pass beneath Grand Mesa.

The base of the Mancos shale was not observed in the eastern part of the region examined, but according to Eldridge the transitional 
zone between the Dakota sandstone and the Mancos shale in the Crested Butte field at the eastern end of the area is essentially the same as that described in the Grand Mesa field, except that no coal has been found in it.

\section{COAL IN THE MESAVERDE FORMATION.}

Two important coal-bearing members of the Mesaverde formation are recognized. The lower or Bowie shale member rests conformably upon the Rollins sandstone, the basal member of the formation, and the upper or Paonia shale member rests unconformably upon the Bowie member in some places and unconformably upon the Rollins sandstone in other places. The highest or undifferentiated part - of the Mesaverde is not known to contain commercially important coal in the West Elk Mountain region, although a thin bed of coal was observed in it in Hubbard Creek canyon, and one is reported also in Coal Creek canyon near the eastern end of the Grand Mesa field at a horizon several hundred feet above the Paonia. However, workable coal occurs in other parts of Uinta Basin, as shown by Gale, ${ }^{1}$ higher in the Mesaverde formation in rocks that may be equivalent in age to those of the upper part of this formation in Grand Mesa.

The Bowie shale has a maximum thickness of about 425 feet in the canyon of Grand River near Palisades, but thins out about 6 miles farther south. The coal bed also thins toward the south and is only a few inches thick a mile south of the river. In the eastern part of the field this shale reappears with a maximum thickness of about 425 feet and apparently thins out again toward the east in the Mount Carbon field, as previously described. The coal beds of the Bowie shale in the eastern part of the Grand Mesa field are more numerous than in the western part, there being at least seven in the Somerset district, whereas in the Palisades district there is one. East of the Grand Mesa field there is only one coal bed that can be referred to the Bowie, and this occurs in the western part of the Mount Carbon field only. The coal beds are more or less lenticular, and although some of the seven mentioned above may become thin or disappear in some places as will be described on a following page, there is probably no place along the outcrop in the Somerset and Coal Creek districts where several beds are not to be found, but prospecting has not been carried on extensively enough to determine the areal distribution of the individual beds.

The Paonia shale member of the Mesaverde formation is continuous throughout the Grand Mesa and West Elk Mountain region, except where it has been removed by recent erosion, and the coal

1 Gale, H. S., Coal fields of the Danforth Hills and Grand Hogback in northwestern Colorado: Bull. U. S. Geol. Survey No. 316, 1907, p. 266. 
beds contained in it appear to be more regular in occurrence and character than those of the Bowie shale. Little can be said, however, of the continuity or character of individual beds until more systematic prospecting has been done. Although the lowest bed in the Palisades district is known to be persistent for a distance of several miles, practically nothing is known of the higher beds. In the Rollins district, coal beds have been opened at many horizons, but little is known of the lateral extent of any of them. In the Somerset district, where the coal is abundant in the Bowie or lower coal-bearing member of the Mesaverde, little attention has been given to the higher or Paonia coals. In the Coal Creek district, only one coal bed is known to belong in the Paonia shale, and although it has been opened only in somewhat widely separated localities, coal blossom in places intervening between the prospects indicates that the bed is persistent over a considerable area.

The association of fossil plants with the coal in the Floresta and Crested Butte fields and with all but the lowest coal bed in the Mount Carbon field is regarded as sufficient evidence that these plant-bearing beds are to be regarded as the eastern continuation of the Paonia shale member of the Mesaverde in the Grand Mesa field.

\section{DESCRIPTIVE DETAILS OF COAL.}

\section{DISTRICTS.}

When coal mining is more extensively developed, the Grand Mesa field undoubtedly will be subdivided into districts, the names, locations, and limits of which will be determined by such centers of development as may be established. No such commercial centers are now recognized, but for convenience of description in this bulletin the field may be divided geographically into the following five more or less well defined districts, shown graphically in figure 2, page 8.

(1) The Gunnison district extends from Grand Junction to Delta and includes only the coal at the base of the Mancos shale. This district is separated from those in the Grand Mesa by a broad belt of barren slopes formed by the main body of the Mancos shale.

(2) The Palisades district includes the Mesaverde coal outcropping in the west slope of Grand Mesa between Grand River and the southwestern point of the mesa, where the coal beds attain their greatest altitude.

(3) The Rollins district extends from the southwestern point of Grand Mesa eastward to Paonia and includes the Mesaverde coal that crops out high in the steep and wooded slopes of the mesa. The line of separation between the Palisades and Rollins districts is arbitrary, as the beds are continuous from the one to the other.

(4) The Somerset district extends from Paonia eastward to the points where the coal beds disappear beneath younger rocks and 
includes the mines and prospects along the north fork of Gunnison River and the prospects on Minnesota Creek. The western limit of the district is arbitrarily drawn to include the mines conveniently reached from Paonia.

(5) The Coal Creek district includes the coal beds accessible from Coal Creek canyon. The coal beds are covered on the north and east of this district by younger rocks.

It is not necessary for descriptive purposes to subdivide the fields of the eastern part of the region, and each field will be treated in the same manner as the districts just named.

\section{GUNNISON DISTRICT.}

$$
\text { (Nos. 1-6). }{ }^{1}
$$

The coal beds of the Gunnison district are probably best exposed at the mouth of Gunnison River, where the following section was measured in the railroad cut near the bridge. The coal beds outcrop in the bluffs of the river; and at these outcrops as well as in the old mine entries, some of which are still open, the coal may be conveniently examined. It occurs in irregular lenses a few inches to 3 feet thick, and these lenses are separated by equally irregular masses of sandstone and shale.

Section of rocks measured at the mouth of Gunnison River.

[For graphic section see fig. 3, No. 4, p. 53.]

1. Shale, dark-colored, fissile (main part of Mancos)........ ?

2. Sandstone................................ 2

3. Shale, dark-colored, with thin layers of flinty sandstone containing Inoceramus labiatus Schlotheim............ 15

4. Sandstone, flinty, in thin layers separated by dark-colored shale containing crystals of gypsum............... 30

5. Coal..................................... 16

6. Shale, carbonaceous........................... 4

7. Coal........................................ 28

8. Coal and carbonaceous shale..................... 24

9. Sandstone and carbonaceous shale in alternating layers.... 6

10. Coal..................................... 1

11. Sandstone and shale in alternating layers............ 8

12. Coal..................................... 3

13. Sandstone, thin-bedded...................... 8

14. Coal and carbonaceous shale.................. 3

15. Sandstone, massive, conglomeratic (Dakota) . . . . . . 20

Unconformity by erosion.

16. Variegated beds of the Gunnison formation............ ?

1 The numbers following the names of the several districts refer to localities shown on the accompanying map (Pl. I, in pocket), at which sections of coal were measured or data were collected. 
The occurrence near Grand Junction of the beds of coal shown in this geologic section encouraged the hope that considerable amounts of coal might be found in the Gunnison district, but tbis hope was not realized and after examining the beds in the several places described the writer concluded that the coal had not sufficient economic importance to warrant detailed investigation at that time. However, regulations governing the classification of public coal lands,

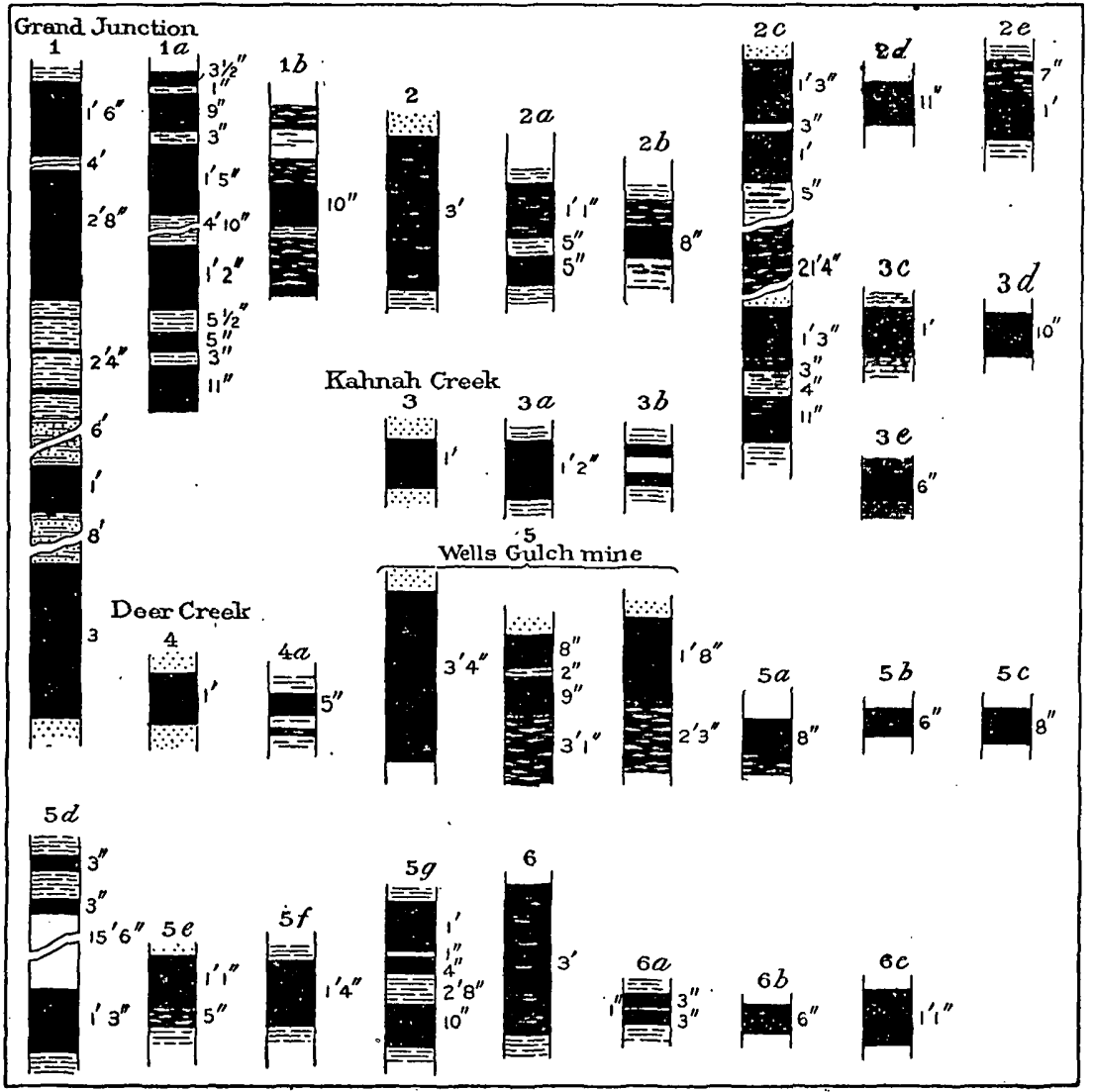

Frgure 4,-Sections of coal in the Gunnison district.

issued more recently by the Secretary of the Interior, made it necessary to examine the coal beds in detail. This examination was made by E. G. Woodruff in the fall of 1910 . The results obtained by him may be found in a paper to be published in an economic bulletin of the United States Geological Survey. From Woodruff's manuscript many data have been taken to supplement the information gathered by the writer and his assistants in the Gunnison district. In the following descriptions in the text, in figure 4, and on the accompanying map, the numerals followed by letters refer to localities examined by Mr. Woodruff and to sections measured by him. 
The transitional zone in which coal is likely to occur is 80 feet or more in thickness near the junction of Grand and Gunnison rivers, where the foregoing geologic section was measured. East of that point there are few places where more than one bed of coal was observed, and in some localities no coal could be found. No one coal bed could be followed continuously for a great distance, and any line connecting exposures on the map should be regarded as the location of a zone of coal-bearing rocks rather than the location of a singlè bed. The coal-bearing rocks outcrop along the crest of a ridge in a manner illustrated in figure 5 . The Dakota sandstone generally forms the crest of the ridge, and one or more of the flinty sandstone layers in the transitional zone above the Dakota constitutes the surface of the dip slope that inclines toward the north away from the canyon of the Gunnison. The conglomerate and the layers of flinty sandstone are well exposed in many places, but the outcrops of the intervening layers of shale and the coal beds associated with them

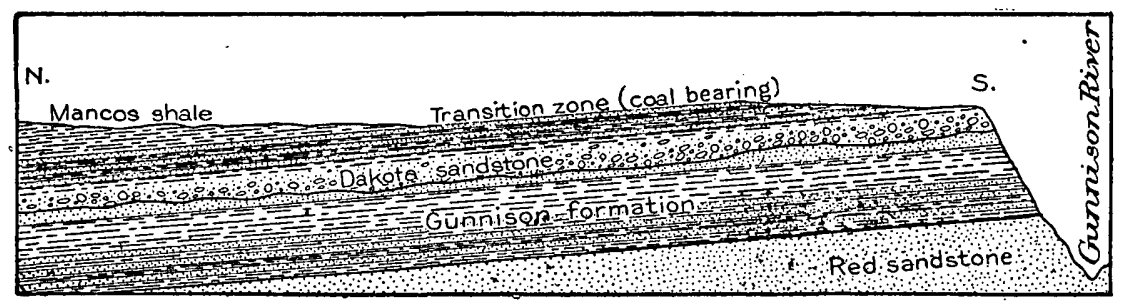

FIGURE 5.-Sketch section showing character of the coal-bearing rocks at the base of the Mancos shale in the Gunnison district and their relation to other formations.

are generally covered with soil. A bed of coal so situated within the transitional zone that it would outcrop in the dip slope would be very difficult to find.

. At localities No. 1 and No. 1a the coal beds were measured in a railroad cut in the same vicinity. Each bed differs greatly in thickness from place to place, so that measurements taken a few rods apart give very different results, as is shown by the two sections mentioned. At locality No. 1a, coal was mined years ago for use in Grand Junction, but when the better coals of the Palisades district were developed this mine was abandoned. One of the old entries is still accessible for a distance of about 125 feet, and in it three samples of coal were collected for analysis. The first sample (No. 5530 of the table of analyses on p. 201) was collected from a face 80 feet from the mouth of the opening, where the weathered coal was cleared away to a depth of several inches and relatively fresh coal obtained. The opening is dry and dusty and doubtless the coal has deteriorated through exposure. The bed is 3 feet thick at this point and is supposed to be the upper bed shown in section No. 1 of figure 4, page 69. At the end of this opening, 125 feet from its mouth and under about 30 feet 
of cover, Woodruff measured the following section and collected samples for analysis. In order to obtain coal unchanged by weathering, he employed a miner to drive the entry into fresh coal, and from the new face of the entry he collected the samples.

Section of coal beds measured near the junction of Gunnison and Grand rivers.

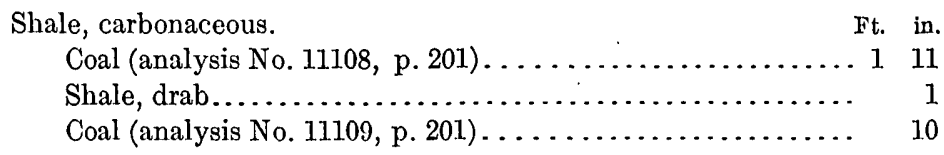

At locality No. 1b, half a mile south of locality No. 1, coal occurs in four thin seams, the largest of which is only 10 inches thick. It is not known whether these thin seams represent all of the coal beds found at locality No. 1. Even with the knowledge of the extreme irregularity of the beds, it is difficult to understand why the coal beds shown in section No. 1 should dwindle within half a mile to those shown in section No. 1b, figure 4, page 69 .

Southeast of locality No. $1 \mathrm{~b}$ no coal was found for a distance of nearly a mile and a half, and apparently its place is occupied by carbonaceous shale; but a 3 -foot bed of coal was observed at locality No. 2, which, although more or less bony, may be of some economic value. At locality No. 2a two thin beds of coal were found, but a quarter of a mile farther south only one thin bed was seen, and apparently this soon changes in character to carbonaceous shale. For a distance of nearly 2 miles southeast of locality No. $2 b$, only carbonaceous shale was found at the horizon of the coal, but at locality No. 2c two beds of coal occur separated by 21 feet 9 inches of sandstone and shale, the shale containing a considerable amount of carbonaceous material. This section (No. 2c of fig. 4, p. 69) is commensurate with that given from locality No. 1 and again raises the query why so little coal should occur at intervening localities.

An entry has been driven in 100 feet on the upper bed of coal at locality No. 2c. A face of the coal in this entry was cleared of weathered material and samples taken from it for analysis. No. 11104 of the table of analyses on page 201 represents the coal of the upper bench and No. 11105 the coal of the lower bench.

One bed of coal was found at each of the two localities, No. $2 \mathrm{~d}$ and No. 2e, within half a mile of locality No. 2c, but for a distance of nearly 8 miles along the outcrop farther toward the southeast only carbonaceous shale and bony coal was found at the coal horizon.

A bed of coal varying from a few inches to 1 foot 2 inches in thickness occurs in the north bank of Kahnah Creek, but apparently it disappears for a distance of 3 miles south of this creek. However, it reappears at localities Nos. 3c, 3d, and $3 \mathrm{e}$ but was not found for 3 miles southeast of locality No. 3e. In Deer Creek canyon it reappears 
again for a short distance and was measured at localities No. 4 and No. 4a. Still farther southeast no coal was found until Wells Gulch was reached, a distance of about 4 miles as measured in a straight line.

A good opportunity was afforded for observing the coal in Wells Gulch at locality No. 5, where the associated rocks are well exposed, and where an entry has been driven in on the coal bed about 200 feet. The bed is irregular in thickness and character in the mine entry. Near the portal there is a thickness of 3 feet 4 inches of relatively pure coal. One hundred feet from the mouth of the opening this bed breaks up as follows:

Section of coal beds in Wells Gulch mine measured 100 feet from the surface.

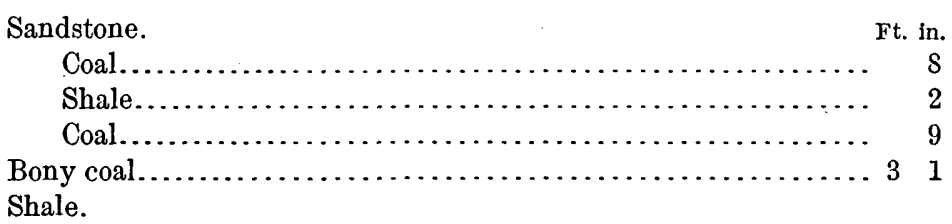

At the face of the opening the following section was measured and samples were collected for analysis:

Section of coal beds in Wells Gulch mine measured at the end of the entry, 200 feet from the Sandstone. surface.

Coal (for analysis see No. 11106, p. 201)..................

Bony coal (for analysis see No. 11107, p. 201)................. 23

Shale.

The sample for analysis, No. 5534 on page 201, was taken from a relatively fresh face of the coal bed 160 feet from the mouth of the opening and includes a thickness of 1 foot 6 inches of the best coal at the top of the bed. This face had been exposed for a year or more, and although the altered coal was removed prior to sampling, the analysis probably does not show the true nature of the coal. Since the time when this sample was taken, more coal has been removed from the mine, and the entry has been driven in 40 feet beyond the point of sampling. At the end of the new part of the entry, where the coal is under a cover of rock about 50 feet thick, Woodruff collected the samples for analyses No. 11106 and No. 11107 found on page 201. The first of these two was taken from the same part of the bed that furnished the sample for analysis No. 5534 .

The coal in this mine is very dry and has a dull luster and general weathered appearance, which may be due to the lack of any considerable thickness of cover. The analyses indicate a fairly good quality for this coal, but practical tests show that it possesses very inferior burning qualities.' However, it has been used locally as a domestic fuel for several years and has been utilized to some extent as a blacksmithing coal. 
No coal was found for a distance of about 2 miles south of the Wells Gulch mine, but at localities Nos. $5 \mathrm{a}, 5 \mathrm{~b}$, and $5 \mathrm{c}$ a thin bed of coal was observed. Again southeast of the latter locality no coal was found for a distance of about 2 miles, but at locality No. $5 \mathrm{~d}$ a coal bed of considerable thickness occurs and extends upstream continuously to the point where the coal outcrop crosses Gunnison River. At locality No. 5 d the coal-bearing rocks are well exposed, and the following section is reported by Woodruff:

Section of coal-bearing and associated rocks in the Gunnison district at locality No. $5 d$ in sec. 35, T. 4 S., R. $3 \mathrm{E}$.

\begin{tabular}{|c|c|c|}
\hline \multicolumn{3}{|l|}{$\begin{array}{l}\text { snale, sandy, yellowisn, merging upward inco the drab snare or } \\
\text { the Mancos. }\end{array}$} \\
\hline 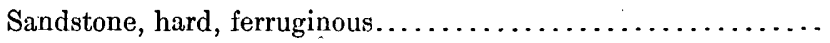 & 2 & \\
\hline 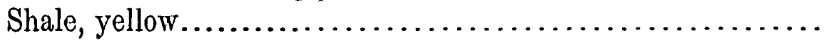 & 3 & \\
\hline Sandstone, hard, ferruginous, in several layers........... & 8 & \\
\hline 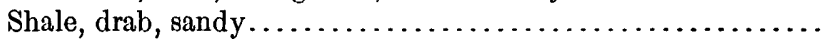 & 20 & \\
\hline 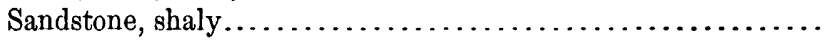 & 5 & \\
\hline 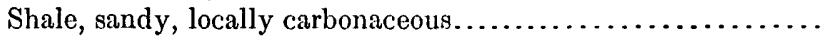 & 17 & \\
\hline Sandstone, massive............ & 9 & \\
\hline Shale, drab......... & 2 & \\
\hline Shale, carbonaceous........ & 2 & \\
\hline$\ldots \ldots \ldots \ldots$ & & 3 \\
\hline 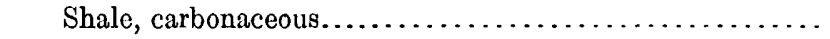 & & 8 \\
\hline 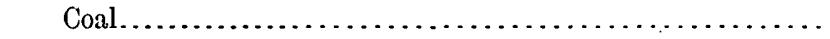 & & 3 \\
\hline Shale, drab, sandy......... & 14 & \\
\hline Shale, carbonaceous.. & 1 & 6 \\
\hline Goal. & 1. & 3 \\
\hline Shale, carbonaceous... & & 11 \\
\hline 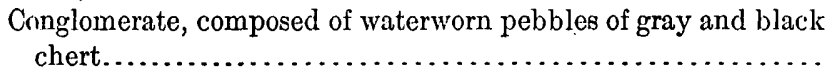 & 26 & \\
\hline Shale, drab & 1. & \\
\hline 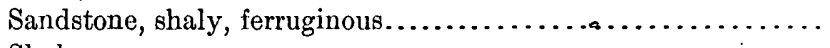 & 5 & \\
\hline & & \\
\hline
\end{tabular}

An opening has been driven in 50 feet on the main coal bed at locality No. $5 \mathrm{~g}$ and the coal is apparently of good quality. At locality No. 6 a bed of bony coal, probably the same as the one just described, was found to be 3 feet thick, but east of this point the bed becomes very thin.

Coal was observed in the transitional zone above the Dakota sandstone, at a point east of Delta near the State bridge at the mouth of Black Canyon of the Gunnison, where it is said to have been mined for several years for blacksmithing. Where observed the beds are less than 2 feet thick, and the roof has fallen, closing the old openings. No further observations were made at this place, but from reports of men who have used the coal it is evidently of no greater value than the coal between Grand Junction and Delta just described. 


\section{PALISADES DISTRICT.}

\section{GENERAL SECTION.}

(Nos. 7-17.)

The Palisades district extending from Grand River southward to the southwestern point of Grand Mesa consists of the area in which outcrop the top of the Mancos shale, the Rollins sandstone member of the Mesaverde, both of the coal-bearing members, the unproductive upper or undifferentiated part of the Mesaverde formation, and the possible equivalent of the Ohio Creek conglomerate. The thickness of these formations at the northern end of the district, their relation to each other, the horizons at which the coal beds occur, and the stratigraphic positions of the fossil-bearing rocks are indicated in the following columnar section. The Bowie shale member does not occur in the southern part of the Palisades district. The Wasatch and Green River formations occur high in the mesa within this district, but the section was not extended to include them.

Section in Grand River valley near Palisades, Colo.

[For graphic section see fig. 3, No. 1, p. 50.]

Shale and conglomeratic sandstone (Wasatch formation). Unconformity by erosion.

1. Sandstone, gray, coarse grained, massive, conglomeratic (possibly the Ohio Creek conglomerate; the Wasatch formation overlies it near by)

Upper or undifferentiated part of Mesaverde formation:

Unconformity by erosion.

2. Sandstone, massive, cliff making, with partings of shale; containing near the top deciduous leaves identified as Ficus speciosissima Ward and Ficus sp.; and about 700 feet lower Sequoia brevifolia? Lesq., Myrica torreyi Lesq., Ficus speciosissima Ward, Ficus sp.? together with shells of the invertebrates Sphxrium sp., Physa cf. felix White, and Goniobasis cf. tenuicarinata M. and $\mathrm{H}$

Paonia shale member of Mesaverde formation:

3. Sandstone with partings of shale containing near the top deciduous leaves and the following nonmarine invertebrates: Unio sp., Tulotoma thompsoni White, Campeloma? sp.............................

4. Sandstone, rusty brown, containing plant remains identified as Sequoia reichenbachi (Gein.) Heer, Geonomites ungeri Lesq..............................

5. Sandstone and shale in alternating layers containing shells of the invertebrates: Unio sp., Unio cf. holmesianus White, Tulotoma thompsoni White, Campeloma (?) sp., Viviparus sp........................

6.

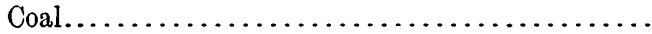

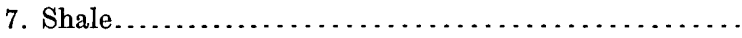

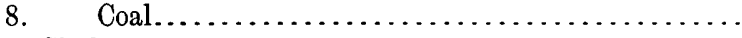

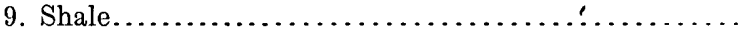

10.

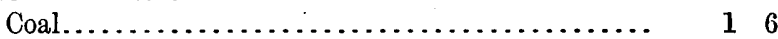


11. Shale, carbonaceous, and sandstone containing plant remains identified as Pteris russellii Newb., Sequoia reichenbachi (Gëin.) Heer, Eriocaulon (?) porosum Lesq., Geonomites ungeri (?) Lesq., Ficus planicostata Lesq., Ficus occidentalis Lesq., Platanus aceroides (Gopp.), Aralia sp., Diospyros (?) sp., and shells of the invertebrates, Unio sp., Sphrrium sp., Tulotoma thompsoni White, Campeloma (?) sp., Viviparus sp., Physa cf. felix White, Corbula subtrigonalis M. and H.

12. Coal

Ft. In.

95

1

30

10

6

3

6

6

13

Unconformity by erosion.

Bowie shale member of Mesaverde formation:

23. Sandstone, gray, coarse grained, cross bedded, cliff making, containing worm tubes, Halymenites major Lesq., and shells of the invertebrate Inoceramus sp. cf. erectus Meek.

24. Shale, dark colored, sandy near the top...............
25. Sandstone, gray, massive, coarse grained, containing Halymenites major Lesq.......................

26. Shale, dark çolored; (At this horizon 4 miles south occur Leda sp., Cardium sp., Tellina sp., and Mactra sp.).

27. Sandstone, gray, massive, coarse grained, cliff making, containing Halymenites major Lesq., and shells of the invertebrates Inoceramus barabini Morton..........

28. Shale, dark colored, containing shells of the invertebrate genera Ostrea sp., Cardium sp., and Anatina sp.

29. Coal (Palisades bed).

Rollins sandstone member of Mesaverde formation:

30. Sandstone, white, friable, coarse grained, cliff making, containing Halymenites major Lesq............. Mancos shale:

31. Shale, dark colored, with limestone concretions containing Placenticeras whitfieldi Hyatt.................

PAONIA COAL.

Cameo bed.-The only coal bed in the upper or fresh-water division of the Mesaverde formation in the northern part of the Palisades district that has been developed is 4 to 7 feet thick and occurs at the 
base of the Paonia shale member. There are several beds of coal at higher horizons in the Paonia, the thickest one measured containing 3 feet of coal, but these upper beds have not been prospected, owing probably to the occurrence of so much coal in thicker beds, and very little is known of them. It is possible that places will be found where some of them may thicken or where several coalesce to form valuable deposits.

The lowest or main coal bed is known as the Cameo bed and is mined at Cameo, north of Grand River. It has been described from this locality by Richardson, ${ }^{1}$ who gives several sections of the bed, two of which are here quoted for comparison with the following sections of the same bed:

Section of the coal bed in the main entry of the Cameo mine.

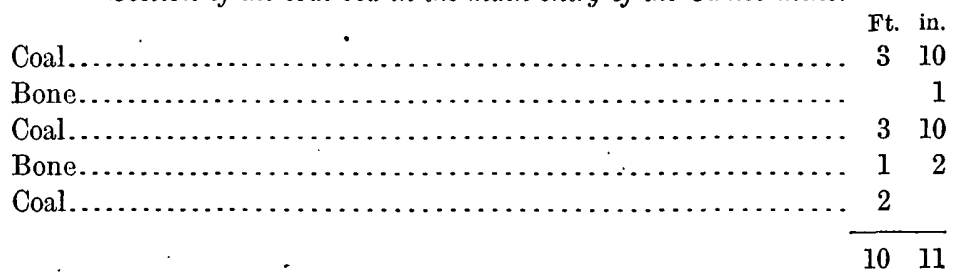

Section of coal bed in room 5 off the main entry, Cameo mine.

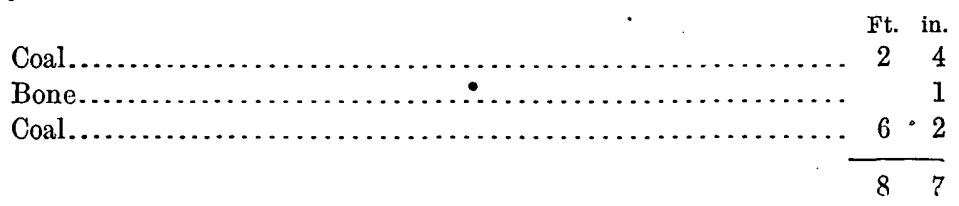

Analysis 3550 (p. 202) was made from a sample taken in this room. It included all of the bed except the bone parting 1 inch thick.

It is relatively uniform in thickness and character and apparently extends continuously throughout the district, as indicated by the correlation lines in figure 6 , although in the brush-covered areas in the southern part of the district its continuity is not certain.

Approach to the outcrop of the coal bed is easy for a distance of about 3 miles along the river northeast of Palisades, but little coal has been mined, and at only one opening, the Bailey mine, at locality No. 7 of the accompanying map, was work being done at the time of investigation. The approach to the coal becomes more and more difficult southward from Palisades, owing to the rugged character of the country and the coal can now be reached by wagon road only at the Patterson mine, locality No. 12.

Bailey mine.-The Bailey mine, situated at locality No. 7 of the accompanying map, was in process of development at the time of investigation, and an entry had been driven in on the coal bed about

1 Richardson, G. B., Reconnaissance of the Book Cliffs coal field: Bull. U. S. Geol. Survey No. 371, 1909, p. 29. 
165 feet. At the end of this entry a sample of coal was taken for analysis, the results of which are given as No. 5724 of the table of analyses on page 202. At this locality there are two benches of coal separated by sandy shale, but only the lower bench is developed.

Section of coal bed at the Bailey mine, NW. $\frac{1}{4}$ SE. $\frac{1}{4}$ sec. 34, T. 10 S., R. $98 \mathrm{~W}$.
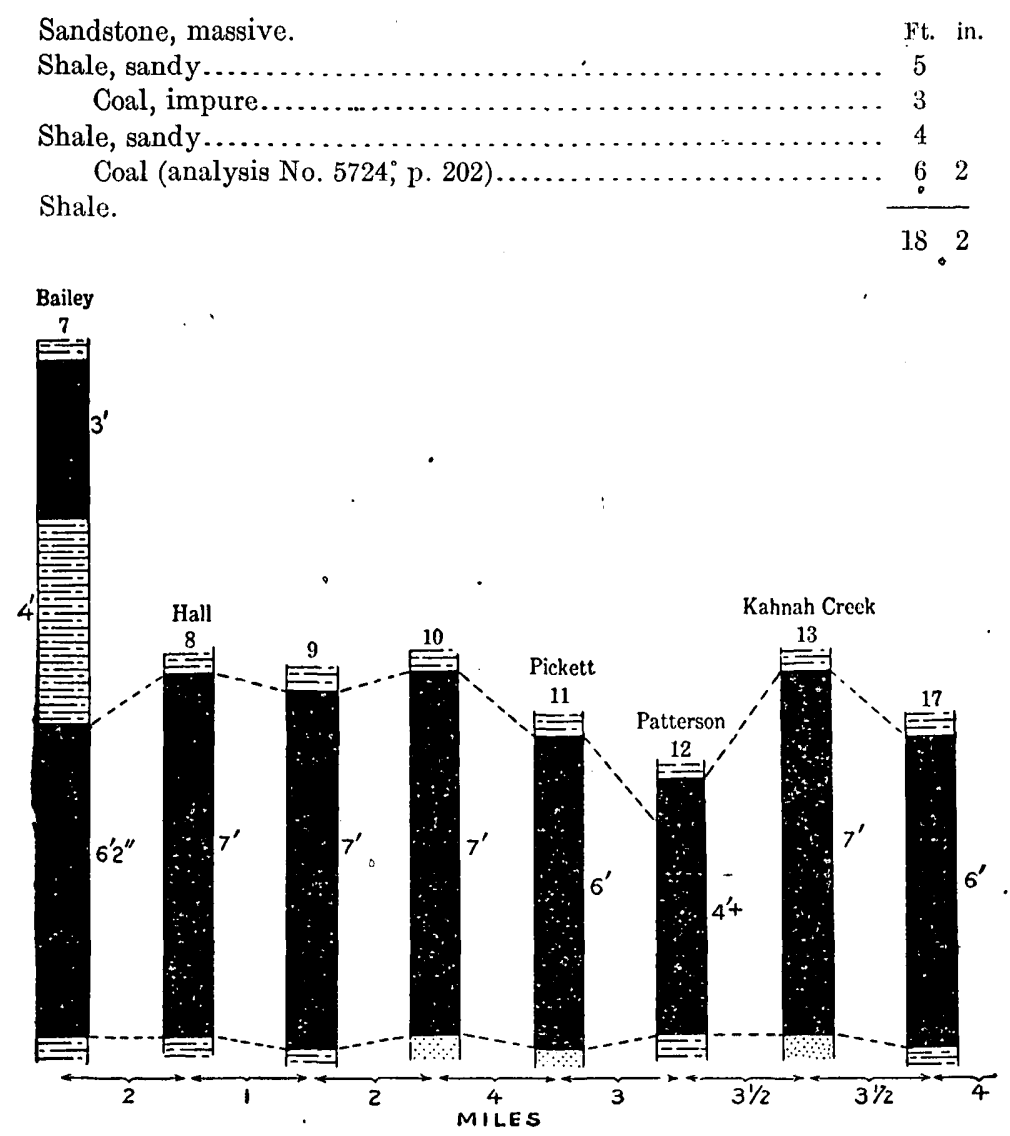

Figure 6.-Sections of coal in the Paonia shale in the Palisades district.

Hall mine.-The Hall mine, situated at locality No. 8 of the accompanying map, is the next place south of the Bailey mine at which the Cameo bed was examined. Coal was noted in several places in the intervening space, but no good exposure of the bed was found. At the Hall mine considerable work had been done, but the mine was not in operation at the time of the investigation, and little was learned concerning it. From the roof of this mine were collected both the fresh-water and the brackish-water shells named in the section below, and about 5 feet above the top of the coal a palm leaf, Geonomites tenuirachis Lesq., was found. 
Section of coal bed at the Hall mine, SE. $\frac{1}{4}$ NE. $\frac{1}{4}$ sec. 2, T. 11 S., R. 98 W.

Shale, containing Anomia micronema Meek, Corbula undifera Meek, and Unio sp.?.

Feet.

Coal

7

Shale.

South of the Hall mine several abandoned prospects were found, and the natural exposures of the Cameo coal bed are numerous as far south as locality No. 16 of the accompanying map. The bed is rather regular in thickness and was measured as 7 feet thick at localities No. 9 and No. 10.

Farther toward the south this coal outcrops in brush-covered slopes and was not examined in detail for a distance of about 4 miles south of locality No. 10. At locality No. 11 an old prospect was found and the coal measured in it as follows:

Section of coal bed at locality No. 11, near Pickett ranch, sec. 6, T. 12 S., R. 97 W.

Shale, sandy.

Feet.

Coal

6

Sandstone.

Patterson mine.-The next point in order southward at which details of the coal beds were obtained is the old Patterson mine, locality No. 12 of the accompanying map.

As previously stated, the Bowie shale member does not occur in the southern part of the Palisades district. The Paonia shale member with its associated fresh water fauna and flora rests upon the Rollins sandstone. This relation is shown by the following columnar section measured at the Patterson mine. This section shows, in addition to the Cameo coal bed, the occurrence of two higher coals, both of which have been prospected at this locality. The old prospects were not accessible at the time of the investigation, and the thicknesses given in the section are those reported by men who had worked at the mine.

Section of coal-bearing rocks measured at the Patterson mine east of Whitewater, Colo.

[For graphic section see fig. 7, No. 12, p. 79.]

1. Sandstone and shale

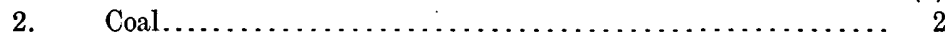

3. Sandstone, containing Sequoia reichenbachi (Gein.) Heer, Myrica torreyi ? Lesq., Myrica n. sp., Ficus speciosissima Ward, Ficus planicostata ? Lesq., Ficus wardii Knowlton............... 10

4. Sandstone and shale with 3 feet of coal near the middle......... 23

5. Shale, carbonaceous................................ 4

6. Coal (Cameo bed) (analysis No. 5535, p. 202)........... 5

7. Shale, with layers of brown sandstone................... 6

(Probable unconformity by erosion.)

8. Sandstone (Rollins), chalky white, cliff making............ 75

9. Shale (Mancos). $\quad \frac{}{105}$ 


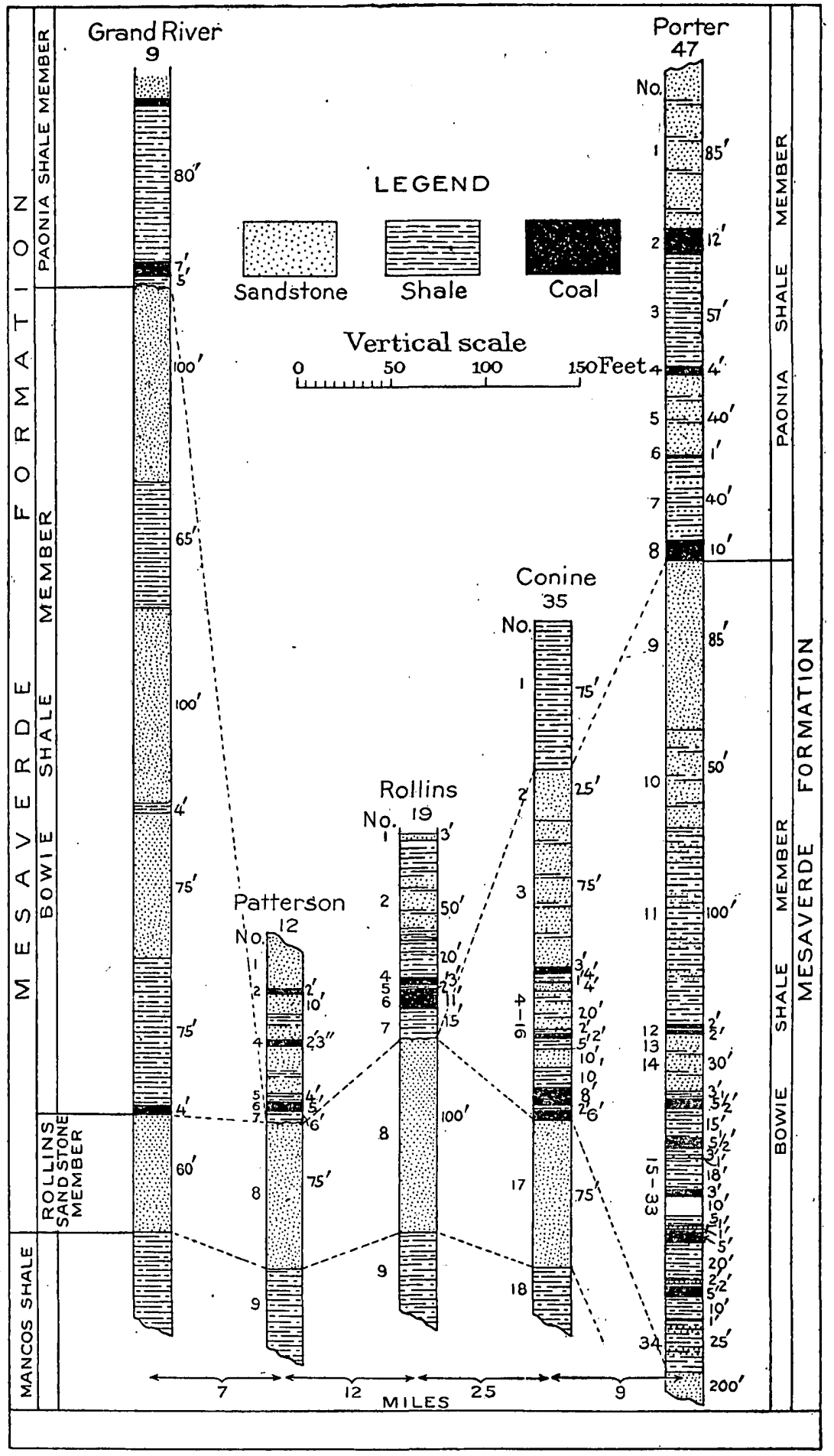

Figure 7.-Detailed columnar sections of the coal-bearing parts of the Mesaverde formation in the Grand Mesa field, showing the disappearance of the Bowie shale member in the central part of the field. 
A sample of coal for analysis was collected from the Cameo bed in an old mine entry 125 feet from its mouth, after a thickness of several inches of coal had been removed from the exposed face. The base of the coal bed, which is 5 feet thick at the outcrop, was not exposed at the place where the sample was taken, and the analysis represents the upper 4 feet of the coal. The results of this analysis are given as No. 5535 of the table of analyses on page 202 .

Over the brush-covered slopes south of the Patterson mine, it is difficult to follow even the coal-bearing horizon, and no attempt was made to trace an individual coal bed. However, coal was found in several places close to the Rollins sandstone-the horizon of the Cameo coal bed. It had been prospected at locality No. 13 on Kahnah Creek, and the following section was measured in the old opening:

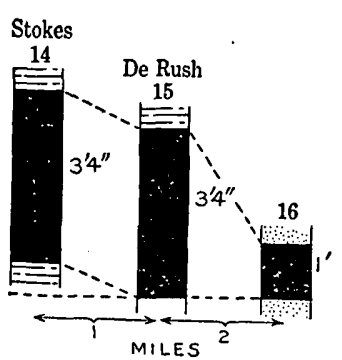

Figure 8.-Sections of coal bed in the Bowie shale in the Palisades district.
Section of coal bed on Kahnah Creek at locality No. 13, sec. 26, T. 12 S., R. 97 W.
Coal ................. 7

Sandstone.

The only place in the Palisades district south of Kahnah Creek at which coal was found is at locality No. 17, where the coal is 6 feet thick. For a distance of about 10 miles along the outcrop in this vicinity the slope of the mesa is covered with rock débris and clothed more or less completely with forests.

BOWIE COAL.

There is only one coal bed in the Bowie shale member of the Mesaverde formation in the Palisades district. It occurs at the base of this member 425 feet below the Cameo coal. It is 3 feet 4 inches thick at the northern end of the district and thins toward the south as shown in figure 8. It has been described north of Grand River as the Palisades coal bed by Richardson, ${ }^{1}$ who reports it to be 3 feet 10 inches thick at the Palisades mine (analysis No. 3541, p. 202) and at the Riverside mine in the north wall of the canyon of Grand River having the following section:

Shale.

Section of coal bed at Riverside mine.

Shale........................................ 3

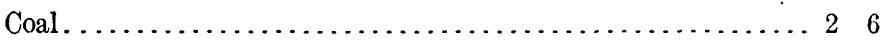

$.3 \quad 3$

1 Richardson, G. B., Reconnaissance of the Book Cliffs coal field: Bull. U. S. Geol. Survey No. 371, 1909 pp. 25-26. 
The Palisades coal is worked in only one place in the Palisades district. From the Stokes mine, at locality No. 14 of the accompanying map, coal is supplied for the local market, and some claim that as a domestic fuel it is superior to other coals of the district. However, analyses (see p. 202) of the coals show little difference in quality between the Palisades and the Cameo coals.

Section of coal bed measured at the Stokes mine, NE. $\frac{1}{4}$ SW. $\frac{1}{4}$ sec. 2, T. 11 S., R. $98 \mathrm{~W}$.

Shale. Ft. in.

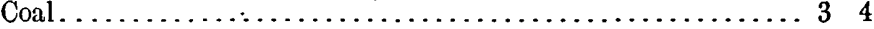

Shale.

The Palisades coal has been mined to some extent at the De Rush mine, locality No. 15, where a thickness of 3 feet 4 inches of coal was measured in the abandoned opening. The base of the bed was not reached. This bed is exposed in many places along the outcrop south of the De Rush mine, but it thins to 1 foot near locality No. 10 and was not found south of this locality.

\section{ROLLINS DISTRICT.}

(Nos. 18-34.)

General statement.-The coal beds of the Rollins district are all in the Paonia shale or fresh-water coal-bearing member of the Mesaverde formation. The Bowie shale is not present in this district, and the Paonia shale rests with apparent unconformity upon the Rollins sandstone. As in the Palisades district, a thick bed of coal usually occurs at or near the base of the Paonia shale, but the higher coal beds are more numerous than those in the Palisades district and some of them attain much greater thicknesses. The lowest bed or group of beds has been prospected in many places, but owing to imperfect exposures no single bed can be followed along the outcrop from place to place, and little can be said of the continuity of the coals. At the western end of the Rollins district, only the lowest bed of coal has been extensively prospected, but there are several relatively thin beds at higher horizons, and these increase in number and thickness toward the east. The position of the coal with respect to the base of the coal-bearing rocks at the localities described is shown in figure 9. There is a notable want of uniformity in the thickness of the coal beds and the horizons at which they occur, and correlations can not be made until the beds are more extensively prospected. Some of the coal beds are known to vary greatly in thickness within short distances, and this, together with the grouping shown in figure 9 , page 83 , strongly suggests that the coal occurs in lenticular bodies rather than in layers that continue throughout the field.

$40642^{\circ}-$ Bull. $510-12-6$ 
The Rollins district contains several small mines at which definite information was obtained and these are described as follows:

Kuhnley mine (No. 18).-Jacob Kuhnley's mine, situated at locality No. 18 of the accompanying map, is about 9 miles north of Delta in the side of Grand Mesa at an altitude of 7,900 feet, or about 3,000 feet above the town, with which it is connected by wagon road. The coal is not exposed at the surface, but the bed was located by a prospect entry driven into the hillside near the top of the Rollins sandstone. The entry has been run in 2,000 feet or more on the coal bed and a considerable amount of coal has been taken from the mine. The bed is overlain by shale and sandstone, but the roof of the mine consists of coal where the bed is thick enough to allow of the upper part being left in place for support. The coal, which varies in thickness from 7 to 16 feet, has a dull luster and conchoidal fracture. It is subbituminous and weathers readily, slacking to a powder within a few weeks after exposure to the atmosphere.

The bed varies greatly in character from place to place, changing within the mine from nearly pure coal through bony coal to carbonaceous shale. Mr. Kuhnley estimates that one-third of the material removed from the mine is discarded as being too dirty for use. In some places the coal contains irregular seams of white clay that run in general parallel with the bedding, but fork in some places and pass diagonally across the bedding planes. The lower 2 feet of coal is apparently of better quality than that above. It is more compact and free from impurities, but is not separated by any parting from the rest of the bed. The floor consists of carbonaceous shale and is slightly undulating, probably due to warping of the rocks, and the coal is more or less fractured, probably from the same cause.

Section of coal at the Kuhnley mine, SE. $S E . \frac{1}{4}$ sec. $34, T .18 S ., R .96 \mathrm{~W}$.

Shale.

Coal, bony in places

Shale.

A sample of coal was taken for analysis where the section was measured about 2,000 feet from the mouth of the entry at a point where the coal was fresh and relatively free from bone. It includes the entire thickness of the lower bench, 7 feet 6 inches. The results of the analysis are given as No. 5541 of the table of analyses on page 202. A fall from the roof near the point where the sample was taken had exposed an upper bench of coal above the upper shale of the foregoing section, but this bench could not be measured.

The Kuhnley mine has supplied coal for local consumption for several years, about 1,000 tons having been mined each winter. It is fitted with track for mule haulage, and the coal is dumped by 


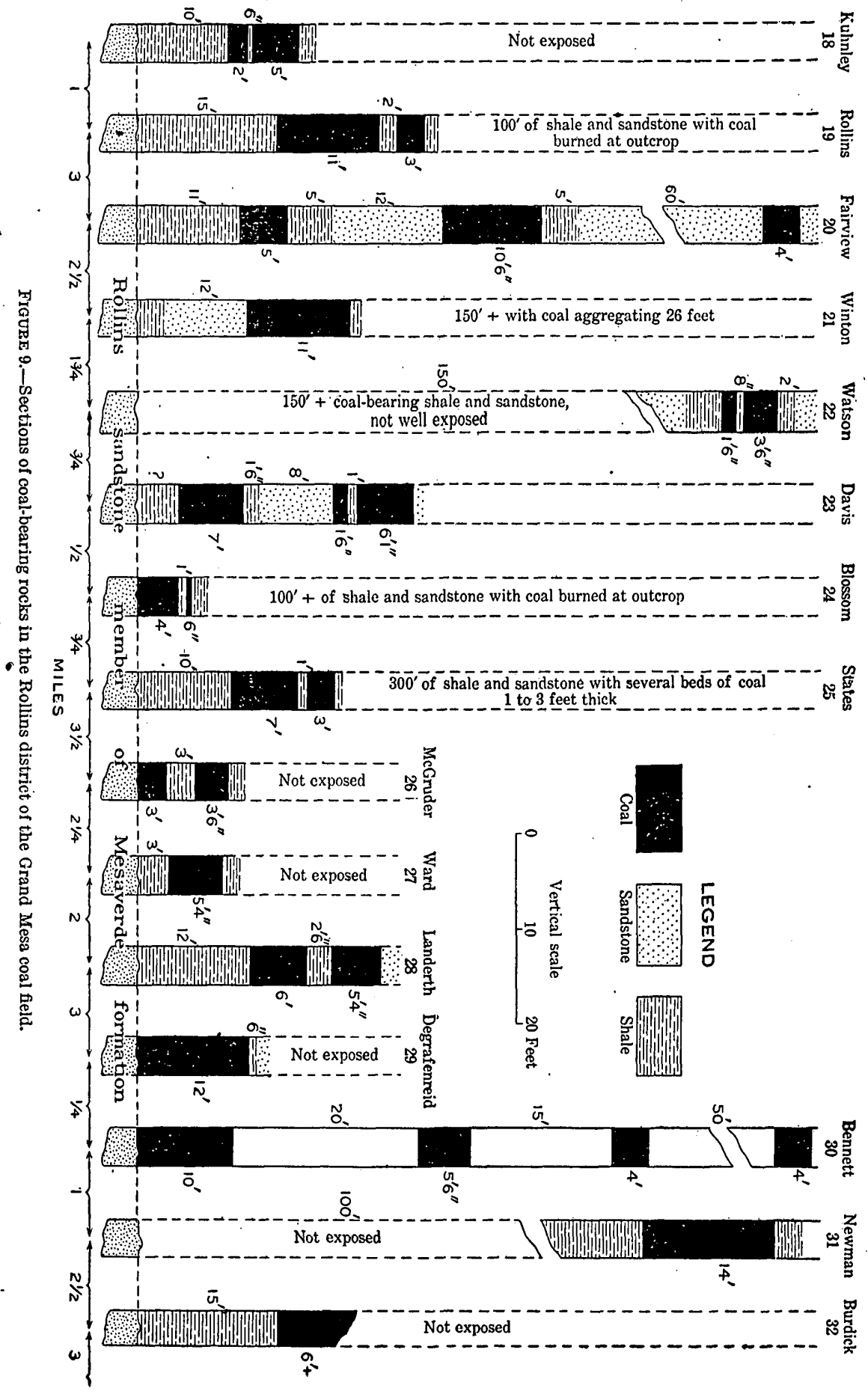


means of a tipple into wagons in which it is hauled to. Delta where it is used as a domestic fuel.

Rollins mine (No. 19).-The Rollins mine is situated at locality No. 19 of the accompanying map, 10 miles north of Delta, with which it is connected by wagon road. The coal bed outcrops in the southern slope of Grand Mesa at an altitude of 7,700 feet and a few feet above the Rollins sandstone, which here forms a prominent cliff (see Pl. III, $B$, p. 15) and dips $4^{\circ}$ due north. A considerable thickness of the coal-bearing formation above this lowest bed is well exposed in the point of the hill east of Rollins mine, where the following section was measured. Coal beds occur at horizons above those indicated in the section, but the coal is burned at the outcrop, and its presence is indicated only by the occurrence of clinker beds at the surface:

Section of coal-bearing rocks at the Rollins mine, near Delta, Colo.

[For graphic section see fig. 7 , No. 19, p. 79.]

1. Sandstone, brown, containing shells of the invertebrates Unio and Viviparus; and plant remains identified as Sequoia reichenbachi (Gein.) Heer, Sabalites? sp., Ficus speciosissima Ward, Ficus trinervis Knowlton, Ficus rhamnoides? Knowlton, and Pterospermites undulatus Knowlton.......................

2. Shale and sandstone with thin beds of coal, containing plants identified as Sequoia reichenbachi (Gein.) Heer, and Myrica torreyi Lesq.................................. 50

3. Shale, carbonaceous................................ 20

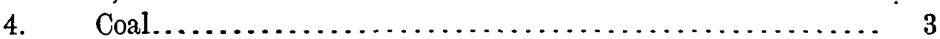

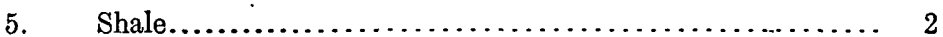

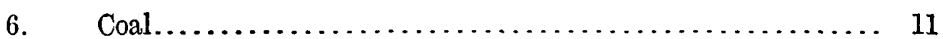

7. Shale, black, fissile............................ 15

8. Sandstone (Rollins), chalky white, cliff making............. 100

9. Shale (Mancos).

Feet. 
There is no bone or other impurity in the coal that can be separated from it in mining, and it makes a good domestic fuel.

Section of coal bed at Rollins mine, NW. 1 WW. $\frac{1}{4}$ sec. $35, T .13$ S., R. $96 \mathrm{~W}$.

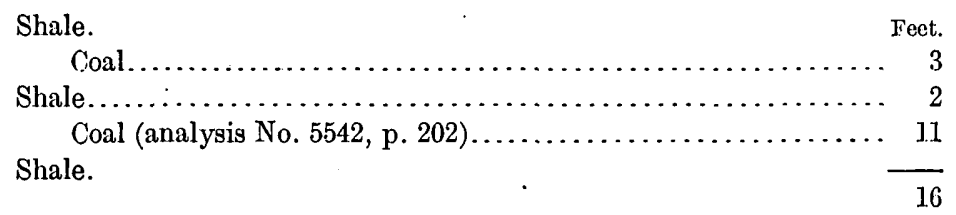

The mine was opened in 1889 , and has been worked every winter since that time, the output averaging about 3,000 tons a year. At the mouth of the mine, resting upon a shelf formed by the Rollins sandstone is a power house (see Pl. III, $B$, p. 15) containing a 50horsepower boiler, a 25-horsepower stationary engine and a 25 -horsepower air compressor. The coal is undercut by a mining machine operated with compressed air and is wedged down, the wedges being inserted in the vertical joints which are well developed and which have a general trend $\mathrm{N} .75^{\circ} \mathrm{E}$. The coal is hauled from the mine to the tipple by rope, and then to Delta by wagon over 'a well-graded road 10 miles long, which has been constructed for this purpose.

A sample of the coal was taken for analysis from a newly exposed face 285 feet from the mouth of the entry and represents the entire thickness of the lower bench.

Fairview mine (No. 20). - The Fairview mine is located in the side of Grand Mesa about 12 miles north of Delta, at locality No. 20 of the accompanying map (sec. 19, T. 13 S., R. 95 W.). A good opportunity was afforded at this locality to determine the relation of the coal-bearing rocks to those above and below. The lowest three beds of coal have been opened at the mine and the lower 250 feet of the following section was measured here. The rocks at higher horizons are well exposed about half a mile northeast of the mine, where the upper part of the section was measured.

Section of rocks measured near Fairview mine north of Delta, Colo.

[For graphic section see fig. 3, No. 2, p. 50.]

1. Shale, blue, alternating with gray sandstone

2. Sandstone, coarse grained, massive, containing petrified wood..

3. Shale, containing plant remains identified as Cyperacites sp., Ficus speciosissima Ward, Ficus planicostata latifolia Lesq., Ficus trinervis Knowlton, Viburnum montanum? Knowlton.

4. Sandstone.

5. Shales, red, green, and blue, alternating with beds of sand-

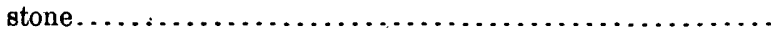

6. Sandstone, massive, friable, containing fragmentary plant remains and shells of invertebrates; Unio (3 species), Campeloma? sp., Corbula sp., Viviparus sp.................. 
7. Shale

8. Sandstone massive

9. Shale, green to purple........................... 5

10. Sandstone, massive, with partings of blue and purple shales.. $\quad 33$

11. Shale, brown to purple........................ 150

12. Sandstone, gray, coarse grained, friable............... 25

13. Shale, containing shells of the invertebrates, Unio sp., Tulotoma thompsoni White; Campeloma? sp., Viviparus sp..... 150

14. Sandstone, friable.......................... 10

15. Shale, carbonaceous in places, containing plant remains.... 75

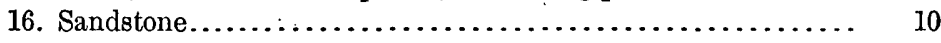

17. Shale, sandy, brown, with thin beds of coal............ 58

18. Sandstone, massive........................... 20

19. Shale, sandy, alternating with beds of sandstone, and containing plant remains.............................. 32

20. Sandstone, brown, massive, cross bedded, with partings of

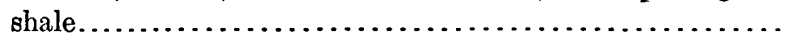

21. Shale and sandstone in alternating layers, coal bearing not well exposed............................. 224

22. Coal................................ 4

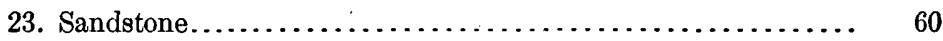

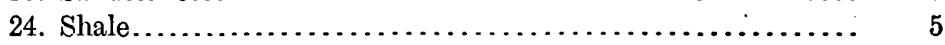

25. Coal, lower 4 feet bony (analyses No. 5540, p. 202)..... $10 \frac{1}{2}$

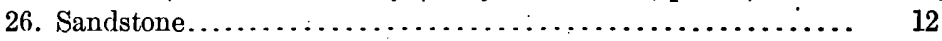

27. Shale, carbonaceous.......................... 5

28. Coal............................... 5

29. Shale.................................. 11

30. Sandstone (Rollins) white, massive, cliff making.......... 100

31. Shale (Mancos) containing shells of the invertebrates Serpula sp., Ostrea sp., Avicula nebrascana E. and S., Inoceramus barabini Mort., Inoceramus sp., Anatina sp., Anisomyon shumardi M. and H.?, Baculites ovatus Say, Placenticeras intercalare M. and H., Scaphites nodosus Owen.

The altitude of Fairview mine is about 7,100 feet or 2,100 feet above the town of Delta, with which it is connected by wagon road. The mine was opened about 1904, but its development has been slow and little coal has been shipped from it. The lowest of the three developed coal beds is separated from the Rollins sandstone by 11 feet of shale and is apparently the bed in which the Rollins mine is developed. The entry to this bed at the Fairview mine was little more than a prospect at the time of investigation. An entry had been driven in 800 feet on the second coal-bed above the base of the coal-bearing formation. This bed is comparatively regular in thickness and character, and the coal is black subbituminous, but rather soft and crumbles readily when exposed to the weather. It is said to be subject to spontaneous ignition, and the mine dump has taken fire several times. The tendency of the coal to disintegrate when exposed to the weather and to ignite easily accounts for the fact that the coal is 
seldom seen at the surface in this region. In some places the coal has weathered more readily than the rocks containing it, and its place of outcrop is occupied by a soil-covered slope. In other places the coal has been burned at the outcrop and the horizons at which it occurs can be determined only by the position of rocks made red by the burning of the coal.

A sample of the coal of the second bed above the base of the coalbearing rocks was taken for analysis from a freshly exposed face 800 feet from the mouth of the mine. It includes a thickness of 6 feet 5 inches of the clean coal above the bony coal. The results of the analysis are given as No. 5540, page 202 .

At the time of the investigation this mine was not equipped for shipping coal in large quantities, but plans had been perfected for installing an electric power plant, and a road bed was being graded for an electric line to connect the mine with the railroad at Delta.

Winton mine (No. 21).-The Winton mine is situated on the western branch of Tongue Creek, at locality No. 21 of the accompanying mapsec. 16, T. 13 S., R. 95 W. It lies 6 miles northwest of Eckert, at an altitude of 6,550 feet or about 1,500 feet higher than Delta, the nearest shipping point. The coal is exposed in the bed of the stream and in the steep bluffs on either side, and several beds have been prospected: The lowest coal, a few feet above the top of the Rollins sandstone, is 11 feet thick and has been mined for about twenty years.

Several beds of coal occur above this lowest one. Thirty feet higher a 4-foot bed has been opened, and 50 feet higher one 6 feet thick. In sinking an air shaft 187 feet deep for the ventilation of the mine, an aggregate thickness of 26 feet of coal was penetrated above the lowest or 11-foot bed. One entry is said to have been driven in about a mile on the 11-foot coal bed from the western side of a small hill, but the direction of this entry is down the dip and it was inaccessible on account of water at the time of the writer's visit. An entry is being driven up the dip from the eastern side of the hill for the purpose of draining the old workings. A new entry has been driven in 500 feet to the present workings. The coal does not vary greatly in thickness or character, so far as observed within the mine.

The coal has a brownish-black color, pitchy luster, and conchoidal fracture, although near the vertical joints it breaks out in cubical blocks. The joints, which are numerous, extend entirely across the bed in a nearly vertical direction and trend N. $72^{\circ} \mathrm{E}$. The coal is moderately soft and slacks to some extent on exposure to the weather; but appears to be slightly better in this respect than the coals farther west.

The bed consists of two benches that can be readily distinguished in mining, although they are not separated by a parting of foreign matter. The coal of the upper bench, 5 feet thick, is relatively soft; 
and in mining it care must be exercised in blasting. The quantity of powder required to loosen the coal of the lower bench would pulverize much of the coal of the upper bench. The lower coal is harder, stands shipping better than that of the upper bench, and is said to be a good blacksmithing coal.

Samples of both benches of coal were taken for analysis from newly exposed faces 500 feet from the mouth of the main entry, and the results of the analysis are given on page 203. Analysis No. 5522 represents the lower 4 feet of the upper bench and No. 5539 the upper

- 5 feet of the lower bench.

The mine is not equipped for supplying a large amount of coal. The work is done by hand, the mine haulage by horse, and the outside haulage by wagon to Cedaredge, Eckert, and Delta, where the coal is

- used as a domestic fuel. Little coal is produced in summer, but the winter output is said to average 250 tons a month.

Watson mine (No. 2.2).-The Watson mine is situated 6 miles northwest of Cedaredge at locality No. 22 of the accompanying map, at an altitude of 6,600 feet. The mine is developed in a coal bed estimated to. be 150 feet above the base_of the coal measures. This bed is 5 feet thick and consists of two benches, separated by 8 inches of shale. An entry has been driven in on the bed 450 feet since the mine was opened four years ago, and about 600 tons of coal have been mined each year.

The coal is overlain by soft, clay shale whieh does not make a secure roof. The upper bench consists of black, subbituminous coal, with vitreous luster, moderately hard and compact, which breaks with conchoidal fracture. It does not slack so readily as the coal farther west, and shows a slight tendency to coke. When tested in the forge the fragments fused to some extent and adhered to each other but did not form coke.

Section of coal bed in Watson mine, SE. $\frac{1}{4} S E . \frac{1}{4}$ sec. $11, T .13 S ., R .95$ W.

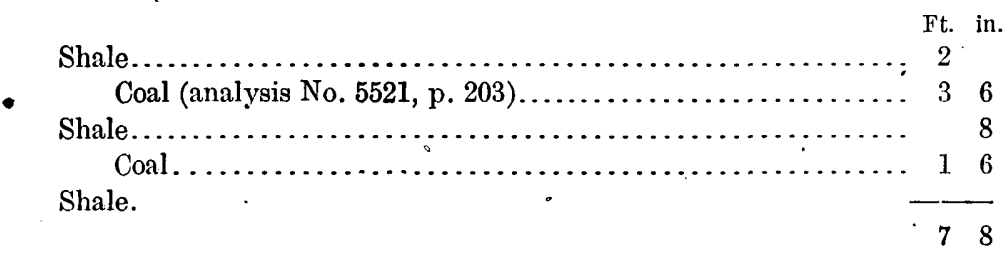

The lower bench of coal is mined with the upper, more for the sake of making room than because it is good coal. It is harder than the coal above and does not burn so readily, although it is said to be much better than the upper coal for blacksmithing.

Davis mine (No. 23). - The Davis mine is situated 5 miles northwest of Cedaredge at locality No. 23 of the accompanying map, at an altitude of 6,600 feet. The mine was opened in 1883 , and was worked 
more or less continuously until 1902 , when it was abandoned and is now full of water. The following information was given by F. M. Fickes, who formerly operated the mine.

The coal beds, two of which have been prospected, lie near the base of the coal-bearing rocks. Entries were run in on the lower or 7 -foot bed to a distance of 500 feet. From one of these a shaft was driven upward to the second bed (see fig. 9, p. 83, section No. 23), whïh was worked to some extent, but the coal was inferior to that of the lower bed and the workings were abandoned. There is a bed of coal 3 feet 6 inches thick, about 50 feet above the upper coal of the Davis mine, and 150 feet above that an 8-foot bed of coal is reported. A prospect was opened in this highest.or 8-foot bed and the coal was found to be free from bone and other impurities. It is apparently of good quality, but nothing has been done toward developing it.

Section of coal beds in Davis mine, SE. $\frac{1}{4}$ SE. $\frac{1}{1}$ sec. $11, T .19$ S., R. $95 \mathrm{~W}$.

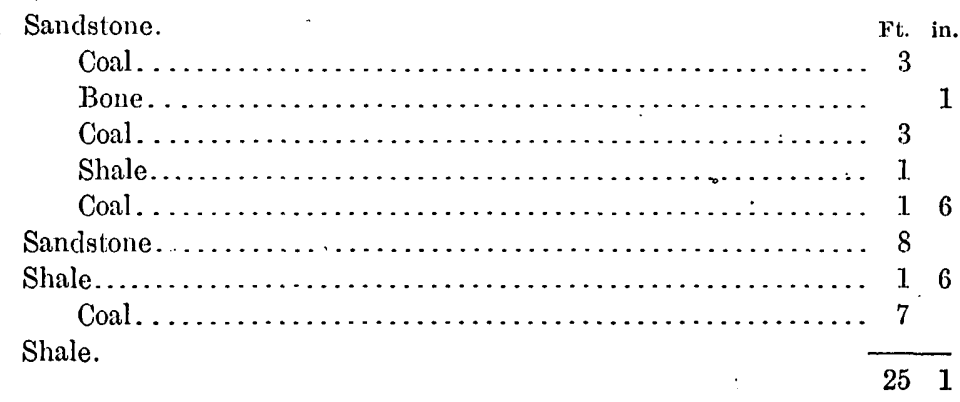

Blossom mine (No. 24).-The Blossom mine is situated about 5 miles northwest of Cedaredge, at locality No. 24 of the accompanying map. An entry was driven in 150 feet on the lowest coal, which is here bony and variable in thickness and rests directly on the Rollins sandstone. At a distance of 150 feet from the mouth of the opening a bed of ash was encountered where the coal had been burned out, and the mine was abandoned.

Coal beds evidently occur in this locality at horizons higher than that of the Blossom mine, but the coals have all been burned at the outcrop. A considerable quantity of the mineral halotrichite consisting of light-green fibers of silky luster was found in this mine entry. It occurs in sheets 1 to 3 inches thick near the top of the coal bed.

Section of coal bed in Blossom mine, NW. $N W$. sec. 1s, T. 19 S., R. $95 \mathrm{~W}$.

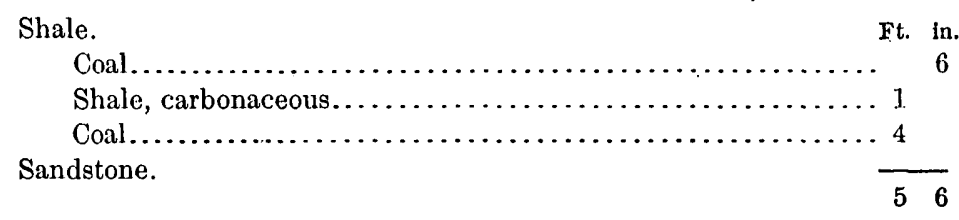


States mine (No. 25).-The States mine is situated 5 miles northwest of Cedaredge, at locality No. 25 of the accompanying map, at a conspicuous point in the side of the mesa known as Red Mountain, the red color of the rocks being caused by the burning of the coal. The mine had just been opened at the time of the investigation and was in process of development, the entry having been driven in on the coal about 125 feet. The coal bed lies at the base of the coal-bearing formation and consists of two benches of coal, as shown in the section below.

The shale above the upper bench is not strong, but the coal of this bench is firm and can probably be used as a roof for the mine. The lower bench consists of relatively soft, black, subbituminous coal, which slacks and crumbles to some extent on exposure to the weather but is otherwise of good quality. The coal contains some bone in - lenticular masses, but these are readily separated from it in the process of mining.

Section of coal bed in States mine, NE. $\frac{1}{4}$ NE. $\frac{1}{4}$ sec.13, T. 19 S., R. $95 \mathrm{~W}$.

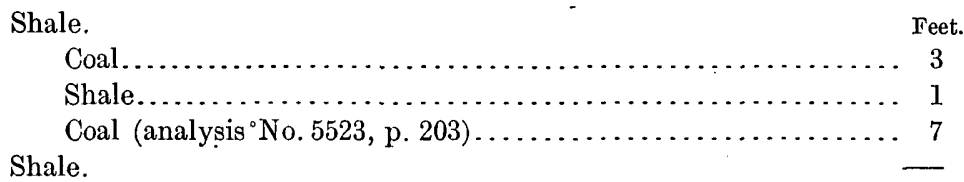

A sample of coal was collected for analysis from a newly exposed face 110 feet from the mouth of the entry and includes a thickness of 6 feet 5 inches of the upper part of the lower bench.

There are several thin beds of coal above the one opened at the States mine. An opening. was made 100 feet above the lowest coal, but only 1 foot of coal was found. A prospect 50 feet higher revealed a bed 1 foot 6 inches thick.

McGruder mine (No. 26).-The McGruder mine is situated in the eastern edge of Cedar Mesa, 3 miles northeast of Cedaredge at locality No. 26 of the accompanying map. The coal bed is about 30 feet above the base of the coal measures. The coal is more or less bony but otherwise appears to be of good quality. The mine was temporarily abandoned at the time of investigation and little was learned regarding it.

Section of coal bed in McGruder mine, sec. 15, T. 13 S., R. 94 W.

Shale.

Coal (analysis No. 5524, p. 203).................... 36

Shale, sandy ................................. 3

Coal............................................ 3

Sandstone. 
A sample of the coal from the upper bench was collected for analysis from a freshly cleared face 250 feet from the mouth of the entry.

Ward (Loomis) mine (No. 27). -The Ward mine, now owned by Elmer Loomis, is situated on Dry Creek 5 miles northeast of Cedaredge at locality No. 27 of the accompanying map. It was opened about a year before the time of the investigation but so far is little more than a prospect. An entry had been driven in on the coal about 200 feet and about 150 tons of coal had been taken out of the mine. The coal bed is 5 feet 4 inches thick and occurs at the base of the coalbearing formation. It is separated from the Rollins sandstone by a few feet of carbonaceous shale.

Section of coal bed in Ward (Loomis) mine, sec. 12, T. 19 S., R. 94 W.

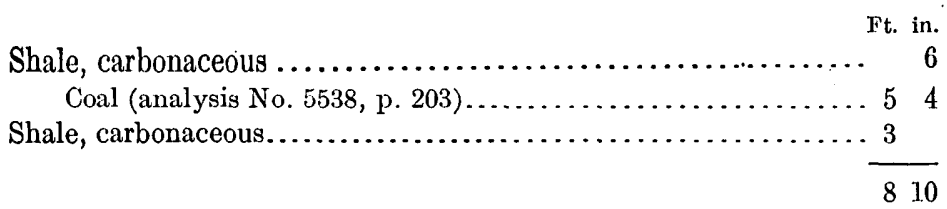

A sample of the coal was taken for analysis from a freshly cleared face 200 feet from the mouth of the entry. The results of the analysis are given as No. 5538 of the table of analyses on page 203.

Landerth mine (No. 28).-The Landerth mine is situated 10 miles north of Hotchkiss on the east fork of Dry Creek at locality No. 28 of the accompanying map. It is little more than a prospect, an entry having been driven in on the coal only 50 feet.

Section of coal bed in Landerth mine, $S W . \frac{1}{4} N W . \frac{1}{4} \sec .8, T .19 S .$, R. $99^{\circ} W$.

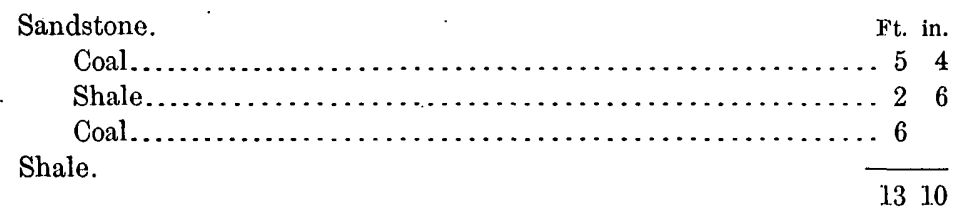

Degrafenreid mine (No. 29). - The Degrafenreid mine is situated at locality No. 29 of the accompanying map in the western slope of Oak Mesa 8 miles north of Hotchkiss, with which it is connected by a wagon road. The coal bed, 12 feet thick without a parting, occurs at the base of the coal-bearing formation, and an entry has been driven in on it 300 feet. The coal is black, subbituminous, and free from bone. The mine had not been worked for two years prior to the time of investigation, but the entry was found in good condition, the roof showing no tendency to fall.

Section of coal bed in Degrafenreid mine, sec. 22, T. 13 S., R. $99 \mathrm{~W}$.

Shale

Ft. in.

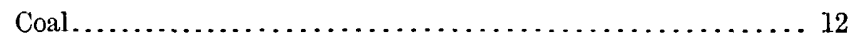

Sandstone. 
Irregular masses of white sandstone are contained in the coal, appar-. ently thrust into it as loose sand after the coal had become hard. They occur principally as tortuous dikelike bodies sometimes following the bedding planes but oftener cutting more or less diagonally across them. Some project from the roof and end within the coal bed; others extend completely across the bed. It is not probable that these masses would seriously interfere with mining, as the sandstone is easily separable from the coal. Several of the masses are exposed in the mine.

Bennett mine (No. 30).-The Bennett mine is situated a few rods east of the Degrafenreid mine at locality No. 30 of the accompanying map. Several coal beds have been prospected at this locality, which is in the SW. $\frac{1}{4}$ NW. $\frac{1}{4}$. sec. 23 , T. 13 S., R. 93 W. The lowest bed is 6 to 10 feet thick and is the same as the one examined in the Degrafenreid mine. The bed of clear coal 5 feet 6 inches thick, in which the Bennett mine is developed lies 30 feet above the top of the basal sandstone (Rollins). There is a 4 -foot bed 50 feet above the Rollins and another 4-foot bed 100 feet above that sandstone. Two more beds are known to occur at higher horizons but have not been prospected. The mine entry, which is said to have been started some fifteen years ago, has recently been driven in on the coal 300 feet from the mouth of the opening, and arrangements were being perfected at the time of investigation to supply coal for the local market. The coal is black, subbituminous, free from bone, and is said to show signs of coking.

A sample of coal was taken for analysis from a fresh face 50 feet from the mouth of the mine. The results are given as analysis No. 5525 on page 203.

Newman mine (No.31).-The Newman mine is situated in the western slope of Oak Mesa, at locality No. 31 of the accompanying map, at an altitude of about 7,700 feet, or 2,300 feet above the town of Hotchkiss, with which it is connected by a wagon road. The mine has been opened recently, the coal from it having been marketed for two years prior to the time of investigation, and the main entry being only 250 feet long when it was examined. The mine is in the SE. $\frac{1}{4}$ NW. $\frac{1}{4}$ sec. 26 , T. 13 S., R. 93 W. The bed consists of 14 feet of clear coal and occurs about 100 feet above the basal or Rollins sandstone. A 6-foot bed of coal is said to occur 8 feet above this bed, but it has not been prospected and little is known about it. The shale above the 14-foot bed is firm and would probably form a good roof, but the upper part of the coal has thus far been left to form the roof of the mine. The coal is black and apparently of very good quality, as it is free from bone and other impurities, but it is said to slack readily on exposure to the weather and to show no sign of coking. It is similar in general appearance to the bituminous coals of the 
Somerset district, but its relatively low heating value and its tendency to slack and crumble when exposed to the weather place it in the subbituminous class. The upper part of the bed is said to consist of coal that is harder and better in some ways than the lower part.

A sample of the coal was taken for analysis from a fresh face 240 feet from the mouth of the entry and includes the entire 14 feet of coal. The results of the analysis are given as No. 5537 of the table of analyses on page 203 .

Burdick mine (No. 92). - The Burdick mine is situated 6 miles north of the town of Hotchkiss, in the southern slope of Oak Mesa, at locality No. 32 of the accompanying map in sec. 30, T. 13 S., R. $92 \mathrm{~W}$. It lies at an altitude of 7,600 feet or 2,200 feet above the town, with which it is connected by wagon road. The bed is near the base of the coal measures and is separated from the Rollins sandstone by 15 feet of shale. The coal is said to be 15 feet thick, although only a thickness of 6 feet 2 inches of it was exposed where it was measured in the mine. The surface on the hillside near the mine is covered with débris and clothed with vegetation, and no coal is exposed. The mine was located by running an entry in at the top of the basal or Rollins sandstone, a horizon at which coal is nearly always found throughout the Grand Mesa field. At the time of investigation the mine had been open for about five years, and the workings had been extended into the mesa 800 feet. The upper part of the coal bed is left to support the roof, and rooms 30 feet wide are worked without timbering.

- The coal has a dull luster and conchoidal fracture and contains irregular lenses and streaks of bone in some places. It is apparently intermediate in character between the subbituminous coals farther west in the Rollins district and the bituminous coals of the Somerset district. Vertical joints trending N. $65^{\circ}$ E. and passing completely across the coal bed are numerous, and are used to some extent in wedging down the coal. Apparently the mine has been worked but little and was temporarily abandoned at the time of investigation. For analysis of sample collected in this mine see No. 5536, page 203.

Stucker mine (Nos. 33 and 34).-The Stucker mine is situated in Road Cap Gulch, at locality No. 33 of the accompanying map; 4 miles northwest of Paonia, with which it is connected by a wagon road. The coal is the lowest one in the coal-bearing formation and consists of two benches as shown in the following section. The lower bench rests on the basal or Rollins sandstone. An opening is said to have been made in it but was not accessible at the time of investigation. An entry had been driven in on the upper or 7-foot bench about 500 feet but was abandoned when visited.

The coal is variable both in thickness and character within the mine. In some places it is apparently of good quality but in others it is very bony. 
Section of coal beds in Stucker mine, sec. $2 \%, T .19$ S., R. 92 W.

Shale.

Feet.

Coal (bony in places) . . . . . . . . . . . . . . . . . . . . 7

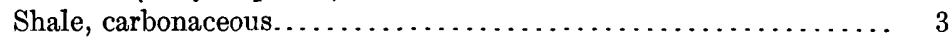

Coal. .................................. 5

Sandstone. $\quad-\frac{}{15}$

Several beds within a vertical distance of less than 100 fect above the one opened are said to have been prospected. According to report one of these is 18 feet thick, but the openings have caved and no coal was seen above the mine.

A mile and a half north of the Stucker mine several prospects in which the coal is well exposed have been opened along the hillside near locality No. 34 of the accompanying map. A. C. Stucker has opened a bed at locality No. 34 about 50 feet above the basal or Rollins sandstone. The bed is said to be 18 feet thick, but a thickness of only 10 feet is exposed in the prospect entry, which has been driven in about 100 feet on the coal bed. At the outcrop the coal is harder than coals found at nearby localities, and hopes were entertained that it would prove to be a semianthracite similar to some of the hard coals known to occur in the West Elk Mountains farther east. However, it became softer inward or away from the outcrop, and evidently the hardening near the surface was caused by burning, as ash and clinker were observed in some places resting on the coal. Beyond the influence of the heat the coal does not differ in character from that of other localities.

Section of coal bed in Stucker prospect, sec. 21, T. 13 S., R. 92 W.

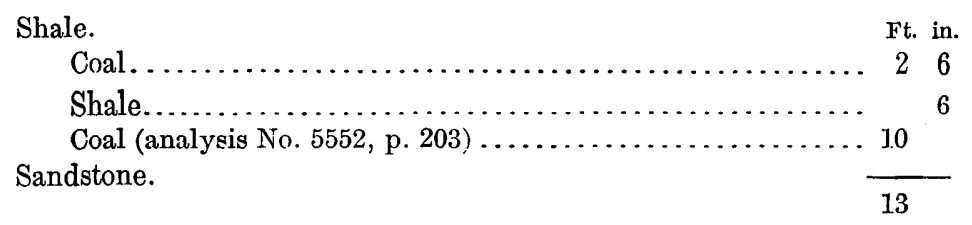

A sample of coal was taken for analysis from a freshly cleared face in this prospect opening and includes the lower 6 feet 6 inches of the lower bench. The results of the analysis are given as No. 5552 of the table of analyses on page 203.

\section{SOMERSET DISTRICT.}

(Nos. 35-48.)

General statement.-The Somerset district contains the coal beds outcropping along the North Fork of the Gunnison and along Minnesota Creek east of Paonia. At the west end of the district the coal is about 1,000 feet above the valley of North Fork, but at Somerset the 
line of outcrop comes down to the river. East of Minnesota Creek the coal underlies the mesa and outcrops again on Coal Creek, which has cut its canyon down to the coal-bearing rocks.

In the Somerset district coal beds are more numerous and better exposed than they are in the other districts of the Grand Mesa field, and more coal is mined there than in all of the other districts of this field. Both the marine and the nonmarine members of the coalbearing Mesaverde formation are present in this district. The Bowie (marine and brackish-water) member has a maximum thickness of about 450 feet and contains at least seven coal beds of considerable thickness besides several thin coals (fig. 10). At least four beds of coal occur in the Paonia (nonmarine) shale member, but little is known of them as all of the openings in this district, with the exception of those along North Fork between Somerset and Bardine, are in the lower or Bowie shale member.

In many places the coal beds are not well exposed because of brush and slide rock, and complete sections could not be measured. In other places the coal is burned at the outcrop. The best section found of the coal-bearing rocks of the Mesaverde is on Minnesota Creek, east of Paonia and the results are given in the section on page 108. But even at this locality not all of the coal beds were found. Ash and clinker at several horizons indicate that there are coal beds that do not appear at the surface. The rocks of the highest member (No. 1) of this section and those at still higher horizons are not well exposed on Minnesota Creek, where the section was measured, and it is not certain that there is no coal above the highest bed observed. Thése upper coal beds are soft and disintegrate rapidly on exposure to the weather. For this reason it is difficult to find them at the outcrop.

The rocks of the upper or undifferentiated part of the Mesaverde are best exposed in Hubbard Canyon where the measurements of part of them given in section No. 3 below were obtained. The rocks of the upper 1,000 feet of the section probably do not contain coal beds and consequently were not examined in detail. They consist of . sandstone ranging in thickness from 10 feet to 50 feet or more and separated by layers of shale. In one place where a great landslide had exposed a thickness of about 1,000 feet of rocks, fifteen of these beds of sandstone were observed. The coal-bearing members of the Mesaverde are not so well exposed in Hubbard Creek canyon as they are in Minnesota Creek, but both were found to be very fossiliferous. The Hubbard Canyon section and that measured on Minnesota Creek may well be considered together, for each supplements the other and together they show the stratigraphic relations of the sedimentary 


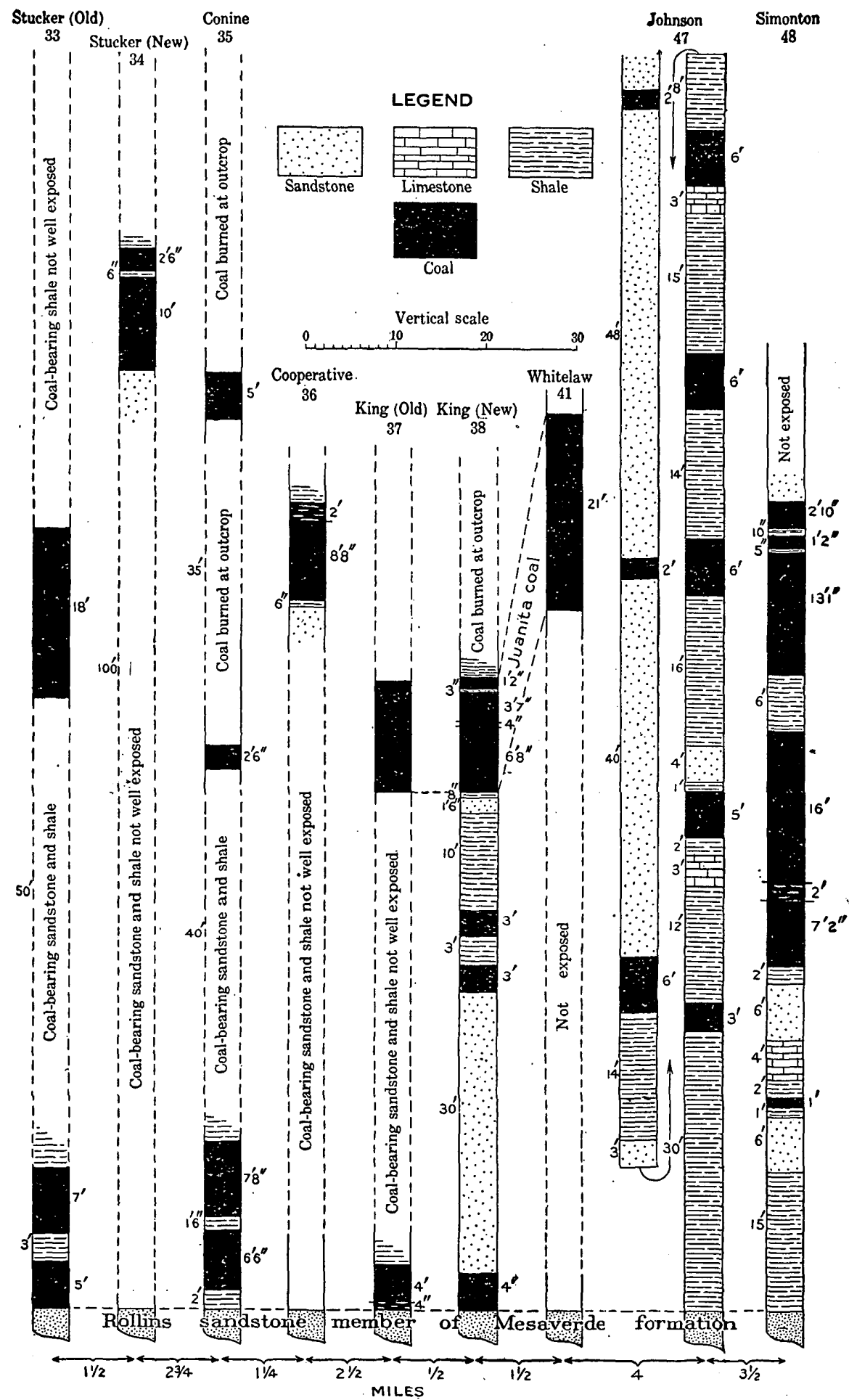

FIGURE 10.-Columnar sections of the coal-bearing rocks in the Somerset district of the Grand Mesa field. 
formations in this district and the horizons at which coal beds are to ${ }^{\circ}$ be expected. They are placed together as follows:

Section of rocks outcropping in Hubbard Creek canyon near Bowie, Colo.

[For graphic section see fig. 3 , No. 3, p. 50.]

1. Sandstone, red, conglomeratic (Wasatch formation)

Feet.

2. Sandstone, white, conglomeratic (Ohio Creek conglomerate?). $10 \dot{0}$

3. Sandstone and shale in alternating layers. ............ 1,085

4. Shale containing plant remains identified as Salix n. sp??, Myrica torreyi Lesq., Ficus speciosissima Ward, and Ficus, probably new?.

5. Shale, carbonaceous, with beds of sandstone; thin coal beds

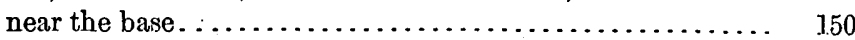

6. Shale and sandstone alternating......................... $\quad 50$

7. Sandstone, cliff making, gray, massive, cross bedded...... 100

8. Covered ..................................... 200

9. Shale and sandstone, partly covered, coal bearing........ 200

10. Sandstone, cliff making, gray, massive, containing Halymenites major Lesq....................................

11. Sandstone with partings of shale containing shells of invertebrates, Ostrea sp., Inoceramus barabini Morton, Cardium speciosum M. and H., and sharks' teeth, Lamna sp........

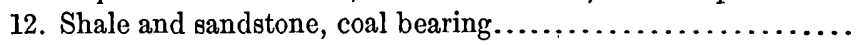

13. Sandstone, shale, and coal, containing shells of the invertebrates: Ostrea subtrigonalis E. and S., Anomia micronema Meek, Anomia sp., Modiola regularis (White), Corbicula sp., Corbula sp., Melania wyomingensis Meek, Melania sp. related to $M$. insculpta Meek.

14. Shale, sandy, containing Ostrea sp., Modiola regularis White, Corbicula sp...................................

15. Sandstone (Rollins), chalky white, cliff making, contains Halymenites major Lesq.............................

16. Shale (Mancos) containing Halymenites major Lesq. and Ostrea sp., Avicula linguiformis E. and S., Cardium speciosum M. and H., Tellina sp., Mactra warrenana M. and H., Mactra formosa M. and H., Mactra sp., Lunatia sp., Turritella? sp., Haminea? sp., Placenticeras intercalare (M. and H.)....... 200

Section of rocks outcropping on Minnesota Creek 6 miles east of Paonia.

[For graphic secticn see fig. 7, No. 47, p. 79.]

1. Sandstone and shale in alternating layers............. 85

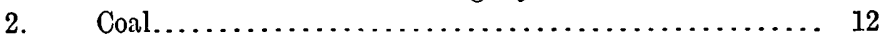

3. Shale and sandstone........................... 57

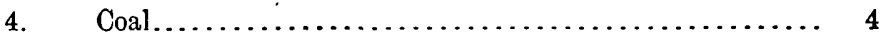

5. Sandstone with shale partings................... 40

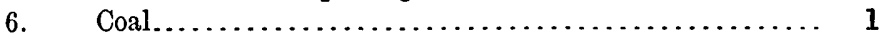

7. Shale with beds of sandstone..................... 40

8. Coal. .................................. 10

Вазе of Paonia shale.

9. Sandstone, cliff making, containing Flalymenites major Lesq. 85 $40642^{\circ}-$ Bull. $510-12-7$ 
10. Sandstone with partings of shale and thin beds of coal. .... 50

11. Shale with beds of sandstone and clinker from the burning of coal. Near the base were found Halymenites major Lesq., . and shells of the invertebrates, Ostrea sp., Inoceramus barabini Morton, Cardium speciosum M. and H., and shark teeth, Lamna sp................................ 100

12. Ash and clinker................................ 2

13. Coal and ash............................... 2

14. Sandstone and shale............................ 30

15. Shale.................................... 3

16. Coal.'................................... 5

17. Shale . . . . . . . . . . . . . . 15

18. Coal....................................... 56

19. Shale................................... 3

20. Limestone consisting principally of oyster shells........ 1

21. Shale . . . . . . . . . . . . . . 18

22. Coal.................................... 3

23. (Not exposed) . . . . . . . . . . . . . . . . . . . 10

24. Shale.................................... 5

25. Sandstone.................................. 1

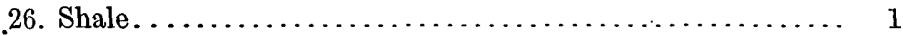

27. Coal..................................... 5

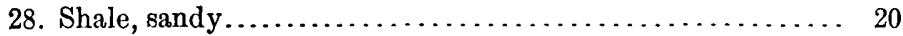

29. Sandstone................................... 2

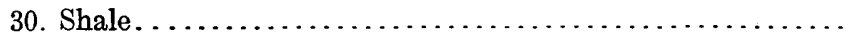

31. Coal...................................... 5

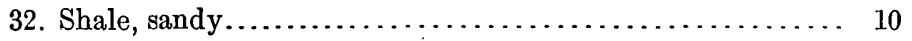

33. Coal................................... 1

34. Sandstone with beds of dark-colored shale containing shells of the invertebrates Ostrea subtrigonalis E. and S., Modiola regularis White, Corbicula sp ................... 25

Base of Bowie shale.

35. Sandstone (Rollins), white, massive, cliff making, containing Halymenites major Lesq........................... 200

36. Shale (Mancos) containing Halymenites major Lesq. and shells of the invertebrates Ostrea sp., Avicula linguiformis E. and S., Cardium speciosum M. and H., Mactra formosa M. and H., Mactra sp., Turritella? sp., Heminea? sp., Placenticeras intercalare (M. and H.).

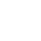

\begin{tabular}{l} 
\\
\hline 859
\end{tabular}

Practically-all of the mining and most of the prospecting in the Somerset district has been done in the lower group of coal beds or those of the marine and brackish water member of the Mesaverde. There are in this member at least seven relatively thick beds of coal, aggregating a thickness of 38 to 43 feet, and there are other beds in it indicated at the outcrop by the presence of clinker, that have not been opened, hence their thickness is not known. Several of the coal beds that have been opened are 5 to 8 feet thick. One known as the Juanita coal is 12 to 22 feet thick, and at the Simonton prospect, locality No. 48 of the accompanying map, there is a thickness of 42 
feet of coal in practically a single bed, one bench of which is 25 feet thick.

The coal beds occur principally in soft shale that crops out in the steep sides of the canyons. Although the slopes are precipitous and cliffs occur wherever hard layers outcrop, as shown in Plate VII, $A$, the outcrops of the coal beds are generally covered with slide rock and brush. The coal beds and their places in the section at the various mines and prospects are plotted to scale in figure 10, page 96 , an inspection of which shows the futility of any attempt at correlating them at the present time, or of mapping any single bed except the Juanita coal even for short distances on either side of the locality in which it was observed.

The Juanita coal bed is probably the best known of any in this district and has been identified on both sides of the canyon of North Fork. It occurs about 50 feet above the base of the Bowie shale, and is worked at the King mine, locality No. 38 of the accompanying map, and has been traced in the canyon side for half a mile or more west of this mine. Farther east it has been opened in Hubbard Creek canyon (locality No. 39) and is supposed to be the coal developed in the Somerset mine (locality No. 42). Prospect openings have been made in it at the Mallott prospect (locality No. 40), and on the Whitelaw claim (No. 41 of the map); but the coal can not be recognized on Minnesota Creek 2 miles southeast of locality No. 41.

The 42 -foot bed at the Simonton prospect (locality No. 48) may be the Juanita coal, but it seems more probable that this thick bed is either one of very restricted development or is due to the çoalescence of several beds. Mr. S. G. Porter who has prospected the coals on Minnesota Creek reports that no coal bed comparable to it in thickness has been found in any of the prospect openings that have been made along the outcrop for a distance of 6 miles north of locality No. 48.

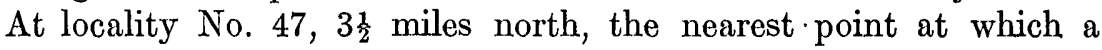
detailed section was measured, there is no bed that can be correlated certainly with any part of it. (See fig. 10, p. 96, sections 47 and 48.)

It is obvious that the coal occurs in beds that vary greatly in thickness within short distances, and it is possible that the beds form more or less distinct lenses. These lenses may be separated by beds of shale and sandstone or may coalesce, forming thick beds of coal, as suggested in explanation of the 42-foot bed of the Simonton prospect. This bed is made up of six benches, which, together with the 1-foot bed below, may possibly represent the seven beds of the section measured at the Johnson prospect (locality No. 47 of the accompanying map; see also fig. 10, p. 96), which are there distributed through a thickness of 164 feet. However, since the coal can not be traced continuously at the outcrop, the determination of the form and extent of individual beds must be left for future investigation. 
Conine mine (No. 35).-The Conine mine is situated 3 miles north of Paonia, at locality No. 35 of the accompanying map, in the side of the mesa at an altitude of 7,300 feet, or 1,500 feet above the town, with which it is connected by wagon road. The coal is at the base of the coal-bearing formation and is separated from the basal or Rollins sandstone by 2 feet of carbonaceous shale. The mine was opened in 1906 and development rather than mining on a commercial scale was in progress at the time of investigation.

The béd consists of two benches 6 feet 6 inches and 7 feet 8 inches thick, respectively. An entry has been driven in on the upper bench about 300 feet. The roof consists of firm shale that holds up well. The coal is black bituminous, compact, and free from bone. It is comparatively soft, fine-textured, and has thus far been used principally for domestic purposes. It slacks to some extent on exposure to the weather but is much superior in this respect to the coals of the Rollins district farther west.

Section of coal bed in the Conine mine, NW. $S E$. $\frac{1}{4} \sec .24, T .13$ S., R. 92 W.

Shale.

Ft. in.

Coal (analysis No. 5551, p. 204).................. 78

Shale........................................... 16

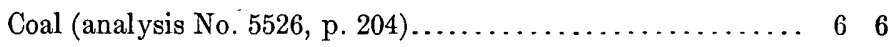

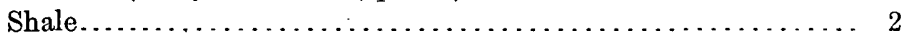

$17 \quad 8$

A sample of the coal of the upper bench was taken for analysis from a fresh face 300 feet from the mouth of the opening. A sample of the lower bench was taken in a prospect opening turned off from the main entry about 300 feet from the mouth. The results of the analysis are given as No. 5551 and No. 5526 of the table on page 204 .

The coal of the lower bench had not been mined to any great extent at the time of investigation, but where it has been opened it is harder than that of the upper bench, and is said to be of better quality. The chemical tests indicate the reverse, for although the upper coal has a greater percentage of ash than the lower, the latter has a lower heating value.

In mining the coal is undercut and either shot or wedged down, the vertical joints being used to good advantage in blocking it out. The coal is hauled from the mine by horse, then passes through an inclined chute to the base of the prominent sandstone cliff, which the Rollins sandstone forms at this place, and is there loaded into wagons and hauled to Paonia. About 500 tons a month were supplied for the local market at the time of investigation.

The coal at horizons above the lowest bed is burned at the outcrop near the Conine mine, but several of these beds are exposed at a prospect known as the Converse mine one-eighth of a mile east. The section shown on the next page was measured at this point. 


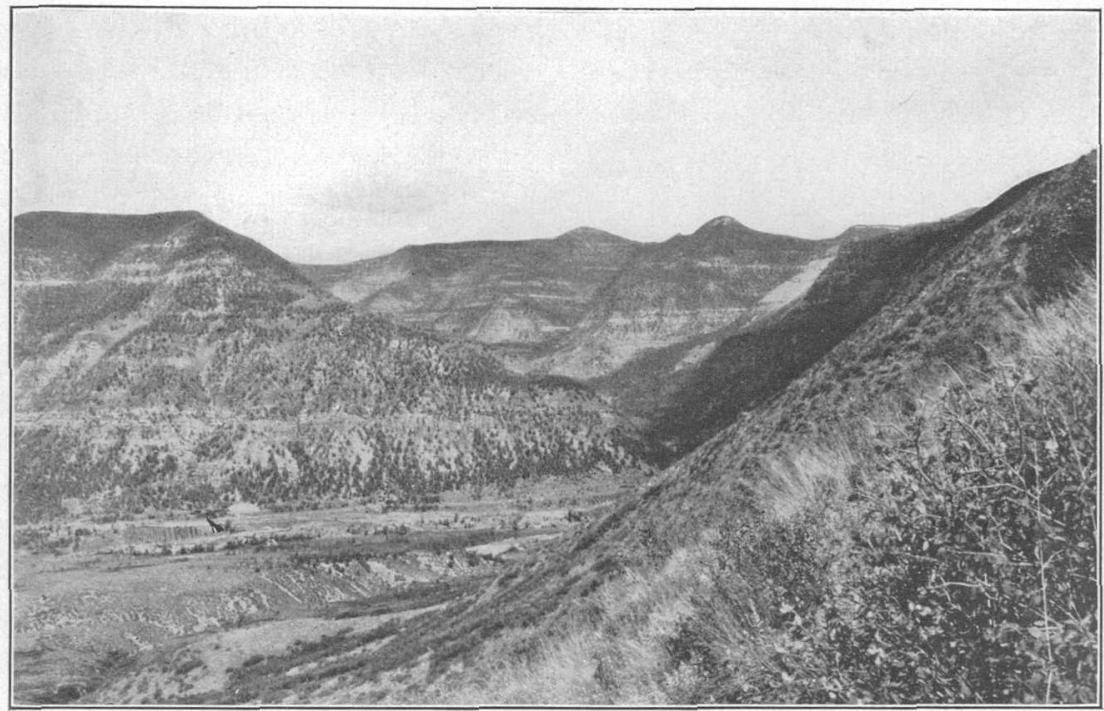

A. CANYON OF NORTH FORK OF GUNNISON RIVER NEAR SOMERSET.

Looking eastward; showing canyon walls 2,000 feet high, consisting principally of sandstones in upper part of Mesaverde formation. The northward-facing brush-covered slopes appear at the right and the rock exposures in the southward-facing slopes at the left.

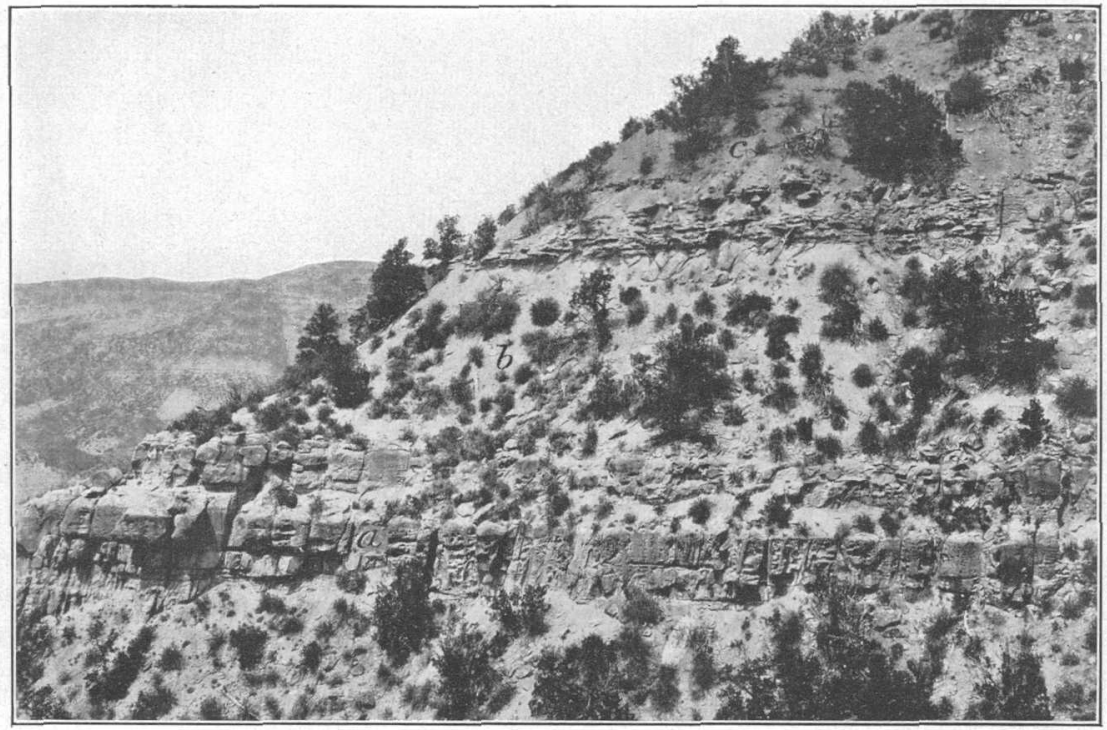

B. TYPICAL EXPOSURE OF COAL-BEARING ROCKS EAST OF PAONIA, COLO.

Showing the lower three members of the Mesaverde formation- $a$, the Rollins sandstone; $b$, the Bowie shale, which here contains seven beds of coal; $c_{1}$ the Paonia shale, containing three beds of coal. The basal sandstone is about 200 feet thick. 
Section of coal-bearing rocks near the Conine mine, north of Paonia, Colo.

[For graphic section see fig. 7, No. 35, p. 79.]

1. Shale and sandstone, reddened by the burning of coal, contains Feet. numerous leaf impressions........................ 75

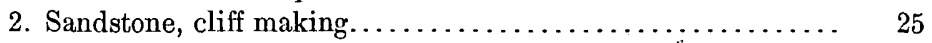

3. Sandstone and shale, alternating layers, coal burned out..... 75

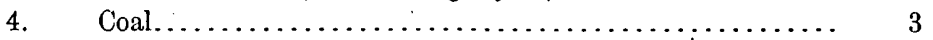

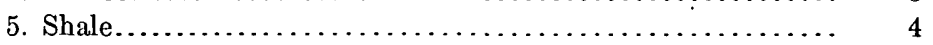

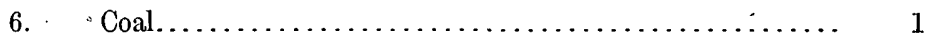

7. Sandstone, massive........................... 4

8. Sandstone and shale, alternating layers............... 20

9. Shale, containing Modiola laticostata White, and Corbula undi-

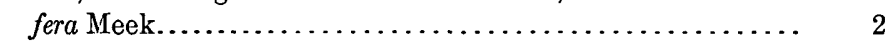

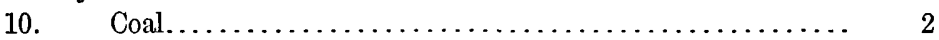

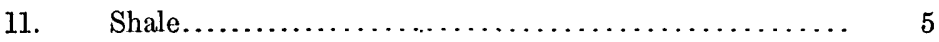

12. Sandstone....................................... 10

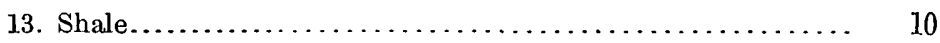

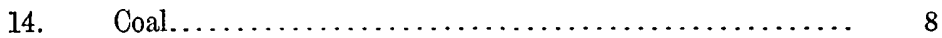

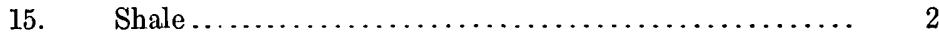

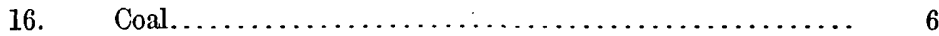

17. Sandstone (Rollins), chalky white, contains worm tubes and Halymenites major Lesq........................ $\quad 75$

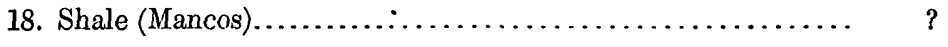

327

A coal bed about 50 feet above the Roilins has been opened at the Dorrance mine, half a mile east of the Conine mine. This mine is said to have been worked for several years, and the coal was reported to be of very good quality, but the workings were abandoned at the time of investigation and the entry was not then in condition to be examined. Openings had also been made at this place in the coal bed just above the Rollins sandstone and in a coal bed 100 feet above the top of the base of the coal measures.

Paonia Coal Co.'s (Cooperative (mine) No. 36).- The Paonia Coal Co.'s mine, locally known as the Cooperative mine, was opened in 1903 and is owned by about 200 men living in the vicinity of Paonia, who have the coal mined for their own use. The mine is situated in the side of the mesa 3 miles north of Paonia, at locality No. 36 of the accompanying map, at an altitude of 7,300 feet, or about 1,500 feet above the town, with which it is connected by wagon road.

The coal bed, 10 feet 8 inches thick, is about 175 feet above the top of the Rollins sandstone, and an entry had been driven in on it about 300 feet at the time of investigation. The coal bed consists of 8 feet 8 inches of good coal overlain by 2 feet of bony coal, above which is a massive sandstone. The bony coal is left to form the roof of the mine and holds up well when timbered. The coal is black bituminous, with vitreous luster and conchoidal fracture, is harder than the coal occurring farther west, and does not slack on exposure to the weather. It shows no tendency to coke and is not a good blacksmithing coal. 
Sulphur balls occur in some places, but they separate readily from the coal, and bone does not occur in sufficient quantity to hinder mining operations.

Section of coal bed in Cooperative mine, $S W . \frac{1}{4} S W . \frac{1}{4}$ sec. 1', T. $13 S .$, R. 91 W.

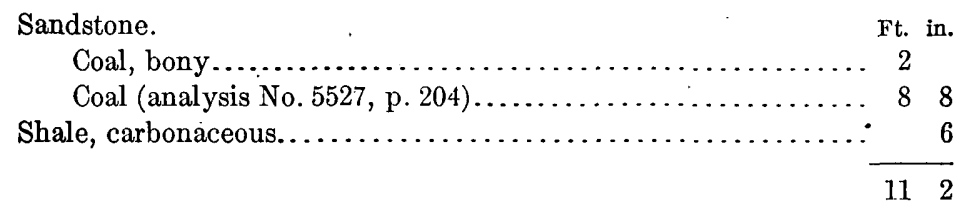

A sample of the coal was taken for analysis from a fresh face 300 feet from the mouth of the opening and includes the clean coal 8 feet 8 inches thick below the bony coal. The results of the analysis are given as No. 5527 of the table of analyses on page 204 .

The mine is dry and dusty, and all water used in it is hauled from the river. The coal is undercut and wedged down where the vertical partings are well developed, but this method is not applicable in some places and the coal is shot from the solid with black powder. The mine haulage is by mule and the outside haulage by wagon to Paonia; the output varies with the season of the year from 100 to 600 tons per month. The coal is used almost entirely as a domestic fuel.

King mine, old opening (No. 37 ).- The old opening of the King mine, now abandoned, is situated in the gulch about 1 mile northwest of Bowie at locality No. 37 of the accompanying map. The coal bed lies just above the Rollins sandstone, and the main entry had been driven in on it 700 feet. The coal is black bituminous, hard, compact, and, except for a few inches of bony coal at the bottom and also in some places at the top of the bed, is clean and of good quality. Its location is in the NE. $\frac{1}{4}$ NW. $\frac{1}{4}$ sec. 15, T. 13 S., R. 91 W.

A sample of the coal was taken for analysis at the end of the entry 700 feet from the mouth of the opening and includes the 4 feet of clean coal above the bone. The results of the analysis are given as No. 5760 of the table of analyses on page 204 .

The mine was actively worked prior to a year before the time of investigation, about 100 tons a day being shipped from it. It was abandoned when a bed of greater thickness containing coal that in some respects is superior in quality was found at the new opening of the King mine, half a mile east.

- Another old opening known as the Gelwick mine on a coal bed 5 feet 6 inches thick just above the Rollins sandstone, is situated half a mile southwest of the old King mine. According to report the Gelwick mine had not been worked for several years prior to the investigation, and the roof had fallen obstructing the entry. Little was 
learned regarding the old mine further than that the coal is the lowest bed in the coal measures.

King mine, new opening (No. 38).-The King mine is situated, at locality No. 38 of the accompanying map, in the side of the mesa at Bowie, a mining town that has recently been built in the valley of North Fork of Gunnison River between Paonia and Somerset. The opening is 600 feet above the town, with which it is connected by a gravity incline. The bed, known as the Juanita, lies about 50 feet above the base of the coal-bearing rocks and is the fourth bed above the basal sandstone (Rollins). (See section No. 38, fig. 10, p. 96.) It is 11 feet 5 inches thick where measured in the main entry to the mine and consists of three benches, as shown in the following section:

Section of coal bed in the new King mine, NE. $\frac{1}{4}$ NE. $\frac{1}{4}$ sec. 15, T. 13 S., R. 91 W.

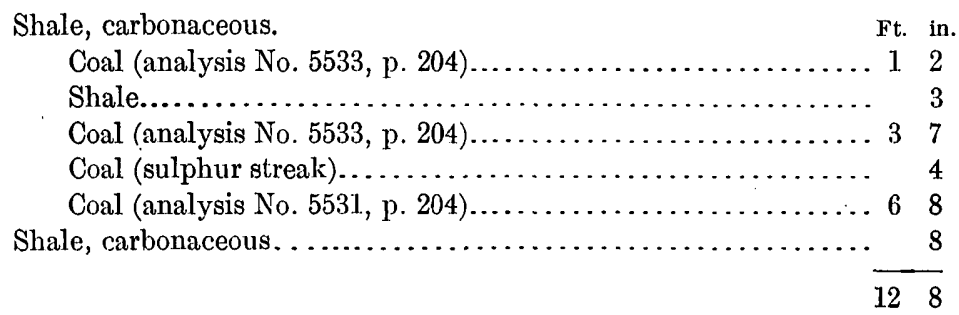

Two samples of coal were collected for analyses from a fresh face 700 feet from the mouth of the mine. No. 5533 represents the upper two benches exclusive of the parting of shale, and No. 5531 represents the upper 6 feet 4 inches of the lower bench. In addition to these samples, No. 5532 was taken from the lower bench 500 feet from the mouth of the mine, where the coal was said to be "dead." The results are given in the table of analyses on page 204 .

Slight variations occur, but so far as developed the bed is found to be practically constant in thickness and character. The coal is black bituminous, with vitreous luster, fine texture, and conchoidal fracture, except near the joints, where subcubical structure is developed, and is sufficiently hard for successful handling and shipment. Except for the 3 inches of shale near the top, no bone or other impurities occur that can not be separated in the process of mining. The mine is well equipped for production; the loaded cars are hauled to the mouth of the mine by mules, where they are lowered over a gravity incline to the tipple at the bottom of the cliff. (See Pl. VI, B, p. 48.) The coal passes over a shaker screen, which separates the lumps from the finer coal, and thence by means of a mechanical loader directly to the railway cars for shipment.

The coal is mined by the room-and-pillar system. It is undercut by hand and is shot or wedged down. The numerous vertical joints 


\section{COAL OF GRAND MESA AND WEST ELK MOUNTAINS, COLO.}

trend $\mathrm{N} .70^{\circ} \mathrm{E}$. and are used to good advantage in blocking out the coal, which snaps from the face with considerable force in some places. The mine is dry and inclined to be dusty, but there is no gas, and good ventilation was obtained at the time of investigation by means of air shafts.

Although this coal probably will coke, no steps have yet been taken toward building ovens, and recent tests seem to show that the coke is not of the best quality. All of the coal mined previous to the time of investigation, about 100 tons a day, had been used for domestic and steaming purposes, and arrangements were being perfected for increasing the output.

Samples of coal from the Juanita bed were collected under the supervision of John W. Groves and sent, under the designation of Denver No. 14, to the Denver branch of the United States Geological Survey Fuel-Testing Plant, where chemical analyses and coking tests were made. The results have been published by Belden ${ }^{1}$ and are as follows:

Bituminous coal from the Juanita 14-foot bed at Bowie, Delta County, Colo., on the Denver \& Rio Grande Railroad, was designated Denver No. 14. One sample shipped from this bed consisted of 34 tons of run-of-mine coal, and was used in making coking tests 242, 243, 244, 245, and 246. Two mine samples were taken for chemical analysis. Sample 378-D was taken 900 feet northwest of the opening, where the coal measured as shown in section $A$; sample $379-D$ was taken 1,070 feet northwest of the opening, where the coal measured as shown in section $B$.

Section $A$.

Roof, 6 feet of good coal. ${ }^{1}$

Coal.

Shale floor.
Section $B$

Coal roof. ${ }^{2}$

Ft, in.

Coal. $\begin{array}{ll}7 & 5\end{array}$

Analysis 378-D (p. 204) represents the coal of section A, 379-D that of section B, and $399-\mathrm{D}$ that of a car sample shipped from this mine to the testing plant at Denver.

Coking tests.

\begin{tabular}{|c|c|c|c|c|c|}
\hline & Test 242. & Test 243. & Test 244 & Test 245. & Test 246 . \\
\hline 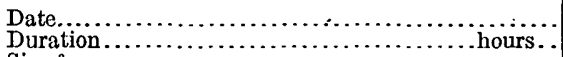 & $\begin{array}{r}3,16,08 \\
65\end{array}$ & $\begin{array}{r}3,17,08 \\
72\end{array}$ & $3,18,08$ & $\begin{array}{r}3,21,08 \\
56\end{array}$ & $\begin{array}{r}3,21,08 \\
48\end{array}$ \\
\hline $\begin{array}{l}\text { Size: }{ }^{3} \\
\text { As shipped. } \\
\text { As used } \ldots \ldots \ldots \ldots \ldots \ldots \ldots \\
\end{array}$ & $\begin{array}{r}\text { r. o.m. } \\
\text { r.,f.c. }\end{array}$ & $\begin{array}{l}\text { r.o.m. } \\
\text { r., f.c. }\end{array}$ & $\begin{array}{l}\text { r. o. m. } \\
\text { r., n.c. }\end{array}$ & $\begin{array}{l}\text { r.o.m. } \\
\text { r., f.c. }\end{array}$ & $\begin{array}{l}\text { r.o.m. } \\
\text { r., f. c. }\end{array}$ \\
\hline 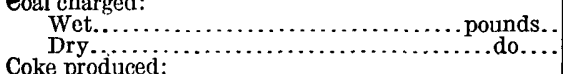 & $\begin{array}{l}12,160 \\
11,771\end{array}$ & $\begin{array}{l}13,300 \\
12,998\end{array}$ & $\begin{array}{l}8,490 \\
8,195\end{array}$ & $\begin{array}{l}11,000 \\
10,678\end{array}$ & $\begin{array}{l}9,280 \\
8,321\end{array}$ \\
\hline Wet.......... & 6,000 & 5,100 & 5,086 & $5,700^{\circ}$ & 4,350 \\
\hline$\cdots\left\{\begin{array}{l}\text { pounds... } \\
\text { per cent.. }\end{array}\right.$ & $\begin{array}{l}49.34 \\
5,987 \\
50.86\end{array}$ & $\begin{array}{l}38.34 \\
5,037 \\
38.75\end{array}$ & $\begin{array}{l}59.91 \\
5,044 \\
61.55\end{array}$ & $\begin{array}{l}51.82 \\
5,681 \\
53.20\end{array}$ & $\begin{array}{l}46.88 \\
4,330 \\
52.04\end{array}$ \\
\hline Breeze produced: & & & & & \\
\hline$\cdots \ldots \ldots\left\{\begin{array}{l}\text { pounds... } \\
\text { per cent.. } \\
\text { pounds... } \\
\text { per cent.. }\end{array}\right.$ & $\begin{array}{l}2,061 \\
16.95 \\
2,056 \\
17.46\end{array}$ & $\begin{array}{l}3,141 \\
23.62 \\
3,102 \\
23.87\end{array}$ & $\begin{array}{r}936 \\
11.02 \\
928 \\
11.32\end{array}$ & $\begin{array}{l}1,212 \\
11.02 \\
1,208 \\
11.31\end{array}$ & $\begin{array}{l}1,770 \\
19.07 \\
1,762 \\
21.17\end{array}$ \\
\hline
\end{tabular}

1 Belden, A. W., Delamater, G. R., and Groves, J. W., Washing and coking tests of coal at the fueltesting plant, Denver, Colo.: Bull. U.' S. Geol. Survey No.' 368,1909 , pp. 23-24 and 48.

2 Not included in sample.

s Abbreviated as follows: r. o. m., run of mine; r., f. c., raw, finely crushed; r., n. c., raw, not crushed. 
Coking tests-Continued.

\begin{tabular}{|c|c|c|c|c|c|}
\hline . & Test 242. & Test 243. & Test 244. & Test 245 . & Test 246. \\
\hline 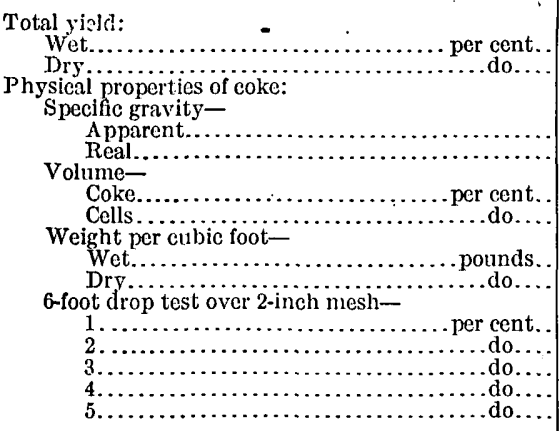 & $\begin{array}{l}66.29 \\
68.32 \\
\\
.91 \\
1.87 \\
49.00 \\
51.00 \\
88.47 \\
56.65 \\
87.50 \\
80.00 \\
73.00 \\
65.00 \\
65.00\end{array}$ & $\begin{array}{r}61.96 \\
62.62 \\
1.01 \\
1.83 \\
55.00 \\
45.00 \\
87.78 \\
62.22 \\
86.00 \\
79.50 \\
68.00 \\
65.50 \\
69.00\end{array}$ & $\begin{array}{r}70.93 \\
72.87 \\
\\
.82 \\
1.76 \\
47.00 \\
53.00 \\
92.54 \\
50.71 \\
92.00 \\
82.50 \\
77.00 \\
72.00 \\
80.00\end{array}$ & $\begin{array}{r}62.84 \\
64.51 \\
. \quad .96 \\
1.76 \\
55.00 \\
45.00 \\
87.78 \\
59.70 \\
90.00 \\
79.50 \\
72.50 \\
66.50 \\
68.50\end{array}$ & $\begin{array}{r}65.95 \\
73.21 \\
\\
.96 \\
1.76 \\
55.00 \\
45.00 \\
87.55 \\
59.47 \\
89.50 \\
77.50 \\
67.50 \\
60.00 \\
57.50\end{array}$ \\
\hline
\end{tabular}

Remarks.-Test No. 242: Fine-fingered coke. Light-gray color. Cell structure small, dense. Breakage, very badly cross fractured. Upper 4 inches fused mass of separate coal particles, no cells; middle 10 inches hard dense coke, fingered; bottom 6 inches separate coal particles not fused together, but with volatile expelled.

Test No. 243: Same as No. 242. Larger per cent breeze, due to larger size of charge and inability to burn to bottom, some unburnt coal being drawn.

Test No. 244: Light gray and silvery color, large deposit carbon. Drawn from oven in lumps same size as charged, from fines to 12 -inch cubes. All volatile expelled. Very fine cells. Metallic ring. Lumps on fracture have appearance of charcoal structure. Very light weight. Charge did not fuse or show any evidence of running together, but every coal particle coked separately.

Test No. 245: Dull-gray color. Poor, soft coke. Fine fingered and badly cross fractured. Metallic ring. Cell structure very small, dense.

Test No. 246: This charge tharoughly wet before charging in attempt to hold back oven and get larger and more open cracks; no results. Produced poor, soft, finefingered coke. Dull-gray color, some little deposit of carbon on upper 2 inches. Cell structure small, dense. Breakage, badly cross fractured. Metallic ring. Very light weight.

Other openings near Bowie (Nos. 39-41). - Several openings have been made in the Juanita bed in the vicinity of Bowie, and these indicate that the coal is fairly constant in character and thickness over a considerable area. H. Mallott has opened a prospect in this coal east of Hubbard Creek, at locality No. 39 of the accompanying map, and two other prospects south of North Fork apparently are on this bed. An old entry, at locality No.40, known as the Mallott opening (not to be confused with Mr. Mallott's prospect on Hubbard Creek) is 50 feet above the base of the coal-bearing rocks, and the entry was driven in 250 feet on the coal bed. Prior to the time of investigation, the entry had been closed by the falling of the roof, but Mr. Mallott, who drove it five years before, stated that the coal cokes readily and is otherwise similar to the Juanita coal. It showed little tendency to slack, and lumps that are said to have lain on the dump for five years are still intact. 
Section of coal bed at the prospect opening on Hubbard Creek (locality No. 39), sec. 12, Shale. T. 19 S., R. 91 W.

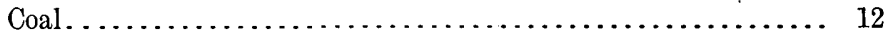

Sandstone.

Reported section of coal bed in the Mallott opening (locality No. 40), sec. 24; T. 13 S., R. $91 \mathrm{~W}$.

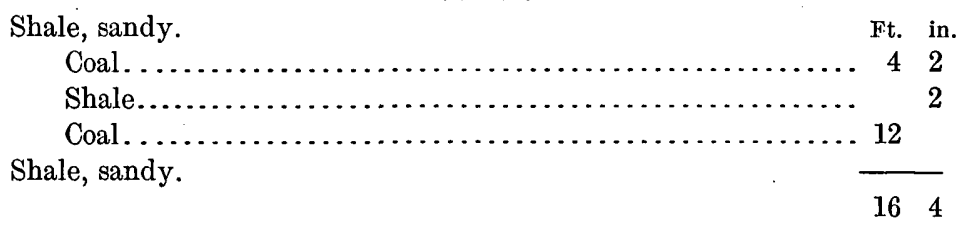

Another prospect situated south of Bowie, at locality No. 41 of the accompanying map, and known as the Whitelaw claim was visited, but the mouth of the entry was filled with slide rock, and no coal was seen. Mr. Alex Bowie's records show that the entry was driven in about 100 feet on the coal, and that the bed is 21 feet thick. This bed is reported to be free from shale partings and bony layers and to be similar in quality to the coal of the new King mine. Its position, about 50 feet above the Rollins sandstone, indicates that it is probably the Juanita coal bed.

Somerset mine (No. 42).-The Utah Fuel Co.'s mine at Somerset is the objective point of the North Fork branch of the Denver \& Rio Grande Railroad and is the largest mine in the Grand Mesa. field. At the time of examination its production was reported to be about 1,000 tons of coal a day, but all information regarding the mine was refused by order of the company. The mine is supposed to be in the Juanita bed, and the mine inspector's report places the maximum thickness of coal in the mine at 22 feet.

Sylvester opening (No. 43).-The Sylvester opening is situated at locality No. 43 of the accompanying map, in the north bank of the river about $1 \frac{1}{4}$ miles east of Somerset. The coal bed is 5 feet 10 inches thick with shale roof and shale floor, and the prospect consists of two entries 70 and 100 feet long, respectively. The coal is hard, black bituminous, with vitreous luster and conchoidal fracture, and breaks out in large blocks. The lower 2 feet is somewhat bony in places, but the remainder of the coal is free from foreign matter that could be separated in mining. The coal is evidently of coking quality, as lumps of it coked readily in: an open fire.

A sample collected for analysis was taken from a freshly cleaned face 70 feet from the mouth of the opening and includes the entire thickness of the bed. The results of the analysis are given as No. 5406 of the table of analyses on page 205 .

The highest bed in which marine shells were found is a massive sandstone, which dips beneath the river west of this prospect, and 
which apparently marks the top of the Bowie in the vicinity of Somerset. Fossil plants were found a fe'w feet above the coal bed. For these reasons the coal is believed to be the lowest bed of the Paonia shale. However, the coal of the Sylvester opening is a highgrade bituminous like those mined at Bowie and Somerset and is much superior in quality to the coals of the Paonia farther west, which are as a rule of subbituminous quality. Possibly this coal was originally of low grade like other Paonia coals and was changed by metamorphism.

About half a mile upstream from the Sylvester opening and south of the river, at locality No. 44 of the accompanying map, an opening was made several years ago. The entry is said to have been driven in on the coal bed several hundred feet and is still accessible for a distance of 100 feet or more. In some places the coal is 10 feet thick, but at no point in the entry was the entire thickness of the bed exposed. The top of the coal has been burned away and in some places the entire bed has been consumed. Fossil plants were found a few feet above the coal, and because of them the coal is held to be one of the beds of the Paonia or fresh-water member of the Mesaverde and may be the same as the one opened in the Sylvester prospect.

Hawk's Nest mine (No. 45).- The coal opening known as the Hawk's Nest mine is situated in the bottom of the canyon of North Fork about 3 miles east of Somerset, at locality No. 45 of the accompanying map. The mine is on public land, and the people living in the canyon take out what coal they want for domestic use. The coal is hard, compact, black bituminous and cokes readily in the open fire. The bed is at least 7 feet thick, but the mine was partly filled with water at the time of investigation and the base of the coal bed was not seen. The coal does not contain large amounts of bone or other impurities and apparently $m$ r.kes an excellent domestic fuel.

Fossil plants of the same species as those found in many places in the Paonia shale occur in the rocks overlying the coal. The northeastward dip of the rocks in this region carries younger and younger beds beneath the surface in an upstream direction. For this reason, if the coal at the Sylvester opening is the lowest in the Paonia, the Hawk's Nest coal should be near the top of the coal-bearing rocks. As a matter of fact, only thin seams of coal were found at higher horizons.

A sample of the coal was taken for analysis 70 feet from the mouth of the opening and includes the upper 5 feet of the bed, the standing water preventing the sampling of the lower 2 feet. The results of the analysis are given as No. 54.05 of the table of analyses on page 205.

Porter claims (Nos. 46-48).-About twenty-five prospect openings have been made by various men in the coal beds along Minnesota Creek east of Paonia. The prospects are locally known as the Porter 
claims, being so named from S. G. Porter, who represents the owners, and who is directing the development of the prospects. At least thirteen beds of coal are exposed at this point, as shown in the following section which was measured near the Johnson prospect, locality No. 47 of the accompanying map (Pl. I, in pocket):

Section of coal beds near locality No. 47 (Johnson prospect) in sec. 6, T. 14 S:, R. 90 W. (land net projected).

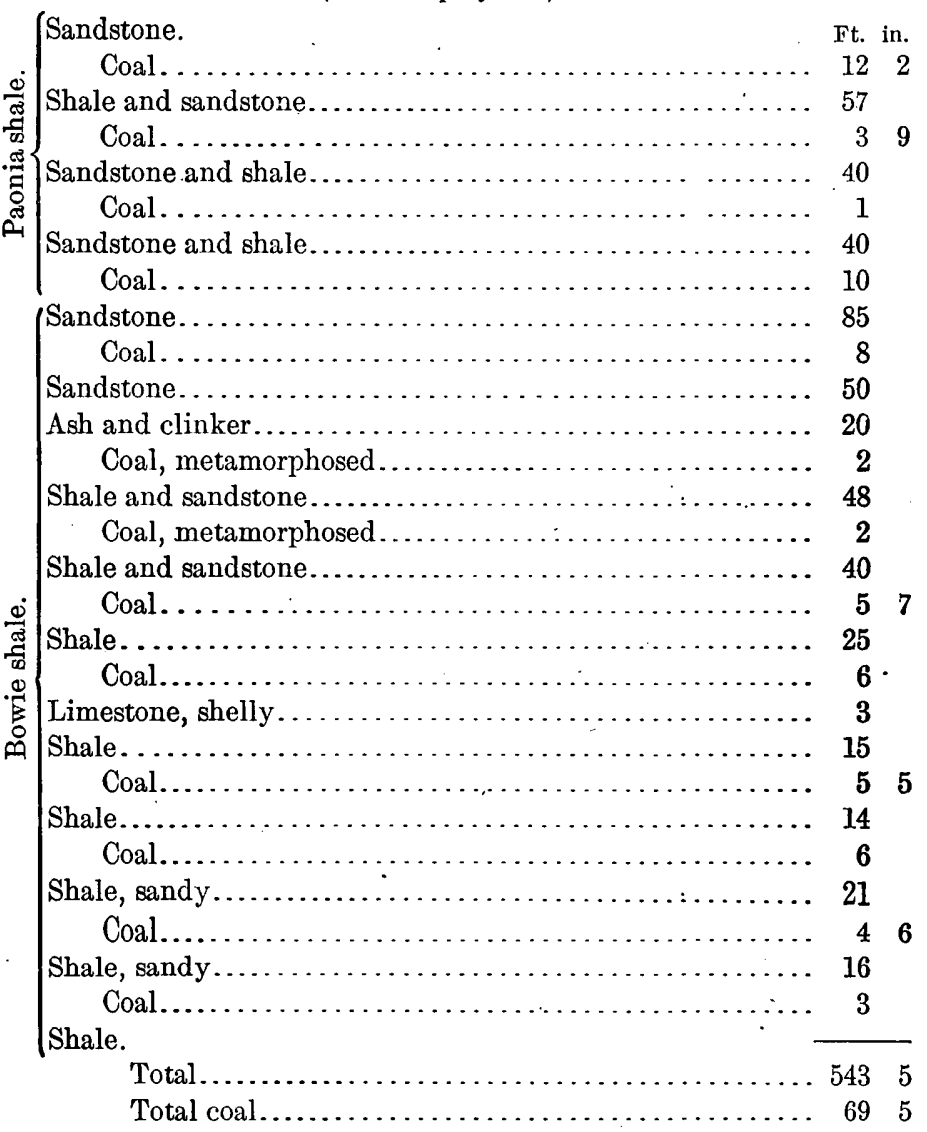

The beds have all been opened. at or near locality No. 47 and the thicknesses of the coal given in the section were obtained from measurements made in the prospects. The coal in two of the beds has been partly burned at the outcrop, and metamorphosed coal, ash, and clinker have been produced. At only one place in them was unburned coal found, and it is not known how thick the unchanged coal is in either of these beds. The coal of other beds is burned at the outcrop in some places near this locality. In no place observed can all of the coal beds be found in one section. Although they vary greatly in thickness, at least ten of them are thick enough in some places to be worked to advantage at the present time. For example, 
the lowest bed, which is 3 feet thick at locality No. 47, is only 1 foot thick less than one-fourth mile south, where the section on page 97 was measured.

The coal at the Shoecroft prospect, at locality No. 46, in sec. 32, T. $13 \mathrm{~S}$., R. $90 \mathrm{~W}$., is about 50 feet above the Rollins sandstone and is 7 feet thick. It is supposed to be the same as the fourth coal bed above the base of the section at locality No. 47 and to be the southward extension of the Juanita coal bed, but this is uncertain. The coal from the Shoecroft prospect does not coke-a fact that casts doubt on its correlation with the Juanita coal. However, the failure to coke may be due to surface weathering. The entry had not been driven through the zone of unweathered coal at the time of investigation.

A sample of the coal in this prospect opening was taken for analysis and represents the entire thickness of the coal. The results of the analysis are given as No. 5807 of the table of analyses on page 205.

The Simonton prospect, at locality No. 48 of the accompanying map, is at the southern extremity of the Somerset district. South of this locality coal is found only in isolated blocks of coal-bearing rocks in the igneous mountains and is of doubtful value. The coal at this prospect is at the base of the Bowie shale and occurs in five benches aggregating 43 feet 3 inches in thickness as shown in the following section:

Section of coal beds at the Simonton prospect (locality No. 48) in sec. 22, T. 14 S., R. $90 \mathrm{~W}$.

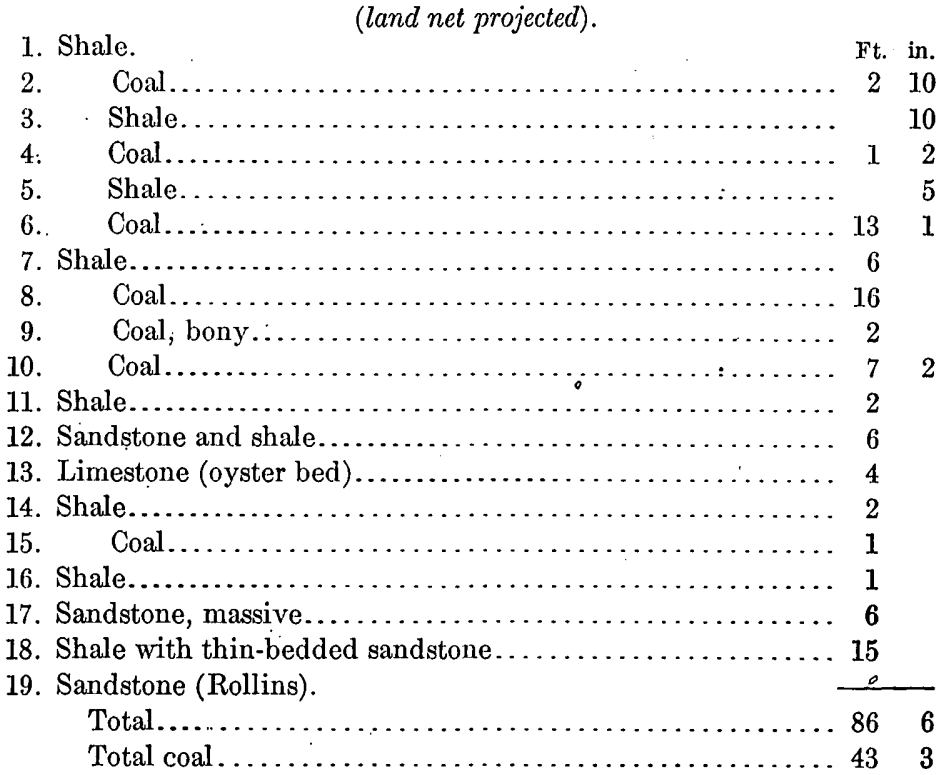

A sample of the coal at this prospect was taken for analysis from an open cut a few feet from the surface. It represents a thickness of 7 feet at the top of the 16 -foot bench, No. 8 of the above section. The 
results of the analysis are given as No. 5529 of the table of analyses on page 205.

The sedimentary rocks at this locality lie on the flanks of Mount Gunnison and $\operatorname{dip} 35^{\circ} \mathrm{N}$. Farther east these rocks are covered with slide rock from the slope of Mount Gunnison. No coal was found between locality No. 48 and Coal Creek canyon, and, although the sedimentary rocks were observed in a nearly horizontal position close to the foot of the mountain, evidence found in the Coal Creek district makes it probable that they do not extend under the laccolithic mass of Mount Gunnison, but are sharply upturned on its flanks underneath the rock slides.

\section{COAL SOUTH OF MOUNT GUNNISON.}

Coal occurs in the south slope of Mount Gunnison at an altitude of 9,700 feet. The locality is about 8 miles northeast of the town of Crawford, with which it is connected by wagon road. The land is not subdivided, but local surveyors have determined that its position corresponds to sec. 6 , T. 15 S., R. 90 W., of the projected land net. The coal-bearing rocks occupy a very small area and occur as more or less crushed, faulted, and contorted blocks included within the igneous rock that constitutes the main mass of the mountains. The coalbearing rocks are very poorly exposed. They are softer and weather more readily than the igneous rocks that surround them, and their surface is covered more or less completely with slide rock from the mountainside. The coal is well exposed only near the prospect opening locally known as the Phillip mine on Little Coal Creek. Through the kindness of S. G. Porter, who is directing the development of the mine, and who had thoroughly explored the region, the writer was able to examine the best exposures of the coal. A section measured by Mr. Porter and later examined by the writer is as follows:

Section of coal beds near the Phillip mine, south of the area mapped, in sec. 6, T. 15 S., R. $90 \mathrm{~W}$. (land net projected).

Igneous rock. Ft. in.

Shale, metamorphosed .............................. 18

Coal..................................... 1

Shale, containing fossil leaves....................... 36

Sandstone, yellow...................................... 6

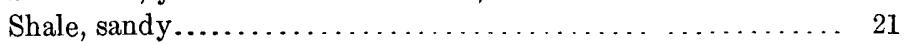

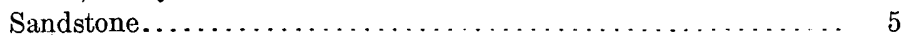

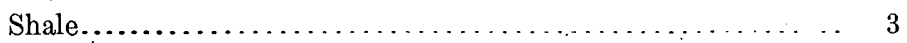

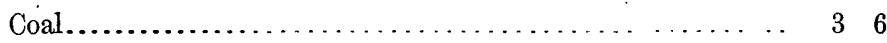

Sandstone, massive.............................. 40

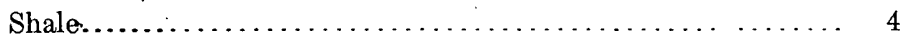

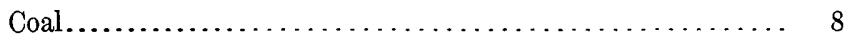

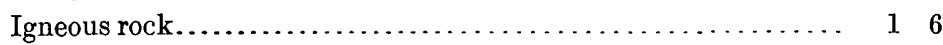

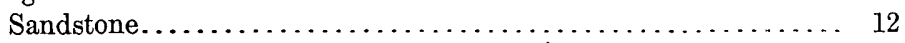

(Lower rocks not exposed.) 
The strata dip $45^{\circ} \mathrm{NW}$. and strike N. $24^{\circ}$ E., but neither strike nor dip is constant for more than a few hundred feet in any one place. At the time of investigation, an entry had been driven in 400 feet along the strike of one of the coal beds. For a distance of 290 feet, the coal varies greatly in thickness due to crushing caused by movements of the rocks and then pinches out. In a prospect entry driven 131 feet down the dip the coal was found more or less uniform in character for a distance of 84 feet, but it decreased in thickness in this distance from 8 feet to 3 feet 6 inches. Beyond 84 feet the coal is crushed, and the bed is irregular in character and finally is reduced in thickness to 8 inches.

The coal is the so-called anthracite of the West Elk Mountain region. It varies in appearance in the mine, the principal part of it being dull black, hard, massive, and very tough. In this dull matrix are many irregular streaks and seams of bright black coal with vitreous luster and conchoidal fracture. The coal has the appearance of being partly melted under pressure, the dull parts having been fused but the vitreous seams having withstood the heat. The source of the heat was evidently the igneous rock that constitutes the main mass of the mountain. A thin dike-sheet of this rock underlies the coal. The coal, which is evidently of the same age as the subbituminous (Paonia) coals along North Fork of Gunnison River, was apparently metamorphosed by the heat of the intruded igneous rock. The movements that in some places have reduced it to a fine powder seem to have been of later date than the metamorphism, for the coal must have been hardened before it could be crushed to an anthracite powder.

A sample of the coal was taken for analysis 250 feet from the mouth of the mine, where the bed is 5 feet 6 inches thick. The results are given as No. 5528 of the table of analyses on page 205 .

Coal is exposed in several places in the gulch of Little Coal Creek near the Phillip mine. One bed of anthracite 12 feet thick is exposed here, but the coal is crushed, and the bed is irregular in thickness, pinching out entirely in some places. Isolated exposures of coalbearing rocks were observed in several places on the sides of Mount Gunnison. Apparently the igneous rock of the laccolith in breaking through the sedimentary rocks carried up blocks of these rocks with it. The blocks are relatively small and because of this together with the disturbed condition of the component strata, the irregular character of the coal beds, and their inaccessibility, the coal is not regarded as possessing any great value. 
COAL CREEK DISTRICT.

(Nos. 49-78.)

GENERAL STATEMENT.

In a preliminary paper on the Grand Mesa coal field, ${ }^{1}$ the Coal Creek area was not recognized as a separate district, and its northern extremity, the only part that had been examined when that paper was written, was included in the Somerset district. The investigations made during the summer of 1909 proved that from an economic standpoint as well as topographically the Coal Creek area constitutes a well-defined coal district. The coal beds of the Somerset district disappear toward the east under a thick covering of younger rocks but outcrop again in Coal Creek canyon. Thus although the coals of the two districts are separated at the surface by noncoal-bearing rocks, the same coal beds are exposed in both districts.

The Coal Creek district occupies the eastern end of the Grand Mesa field and includes those parts of the field in which the coal is most readily accessible from Coal Creek canyon and its tributaries. The coal-bearing rocks. have been more or less disturbed by the intrusion of such great masses of igneous rock as Mount Gunnison and The Cliff (see Pl. IX, B), and by the surface movements that accompanied the formation of the West Elk Mountains. Although the inclination of the strata varies locally both in degree and in direction, the beds have a general rise toward the south so that the coals outcrop in the north slope of West Elk Peak at a maximum altitude of about 10,300 feet. Toward the north they pass beneath the bottom of the canyon at an altitude of about 7,000 feet, the highest coal bed found dipping under the bed of Coal Creek at locality No. 49 of the accompanying map. The rock movements and to some extent also the heat of the intrusive rocks have metamorphosed the coals more or less, so that in some places the coal of a given bed ranges in quality within a short distance from soft bituminous to a hard coal approaching anthracite.

The rock movements, particularly those that have been caused by the intrusion of igneous rocks, have caused variations in the thicknesses of the coal beds, as well as in the quality of the coal. . A notable example of local variation due to movement occurs at locality No. 61, on the east flank of Mount Gunnison, where the coal beds are upturned against the igneous rock at an angle of $35^{\circ}$. Some parts of the coal at this locality show evidence of crushing and recementing, but in other parts contorted laminæ, the absence of partings, and a general massive appearance indicate that the coal probably moved under conditions of heat and pressure that caused

1 Lee, W. T., The Grand Meşa coal field, Colorado: Bull. U. S. Geol. Survey No. 341, 1909, pp. 316-334. 

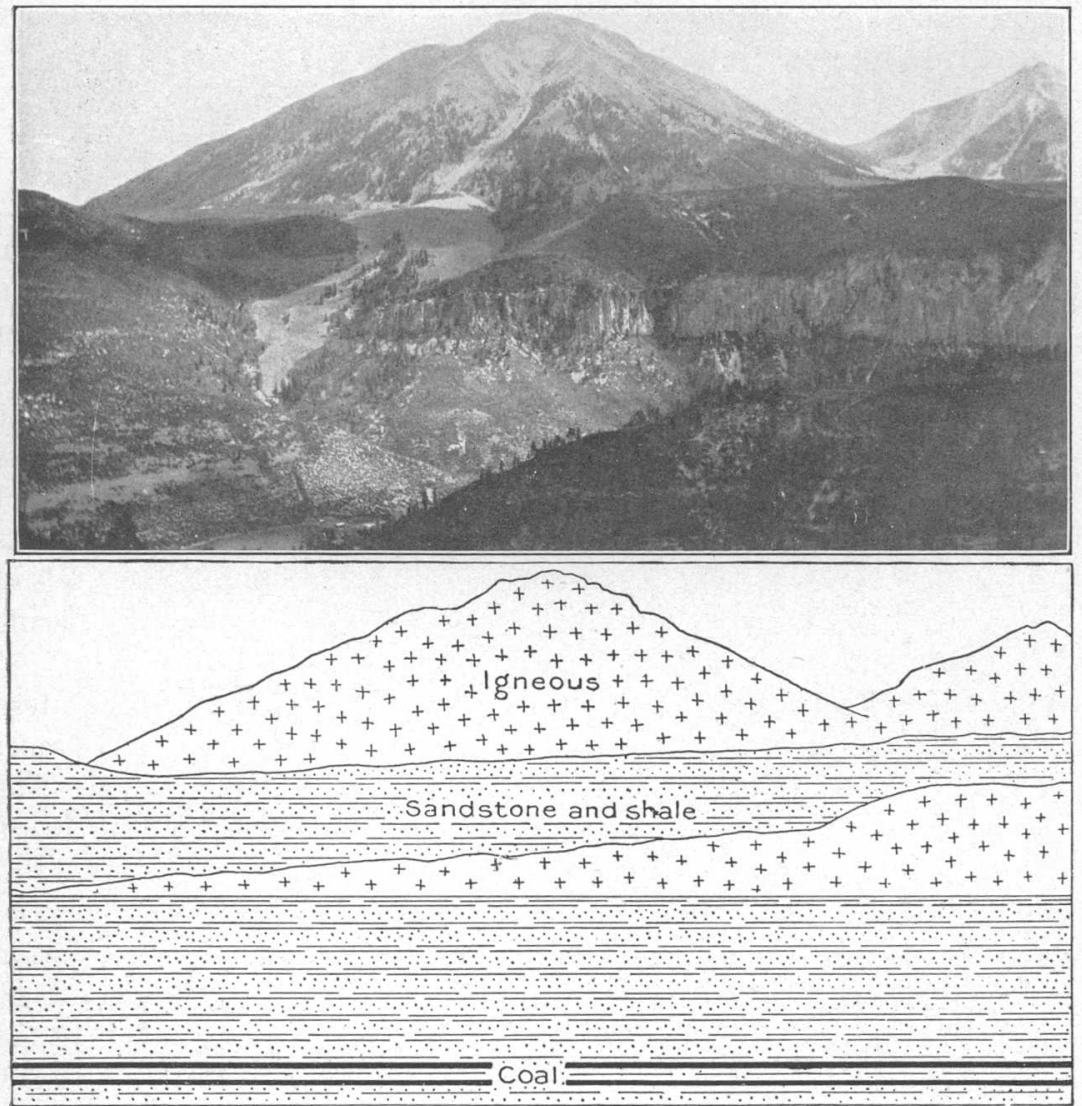

\section{A. CLIFF CREEK CANYON AND MOUNT LOMBARD.}

The coal outcrops near the bottom of the canyon and extends under the igneous rocks about 6,000 feet below the top of the mountain. (For a near view of The Cliff see PI, IX, B.) The stream of fragmental rocks is $1 \frac{1}{2}$ miles long and makes a vertical descent of 4,800 feet. The diagram shows the nature of the rocks and the position of the coal beds.

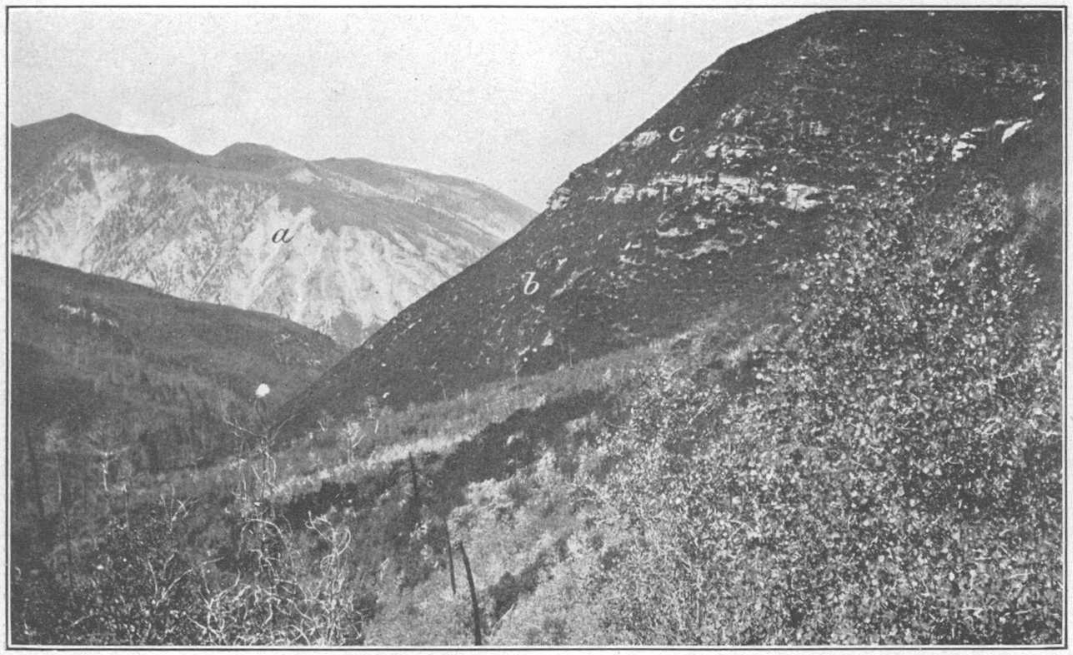

B. ROBINSON CANYON AND MOUNT GUNNISON.

Mount Gunnison $(a)$ at left. Showing the character of the slopes in which the coal beds outcrop. The smooth brush slope $(b)$ in foreground is formed on shale, which here contains seven beds of coal. The cliff $(c)$ above this slope marks the base of the unproductive measures overlying the coal. 


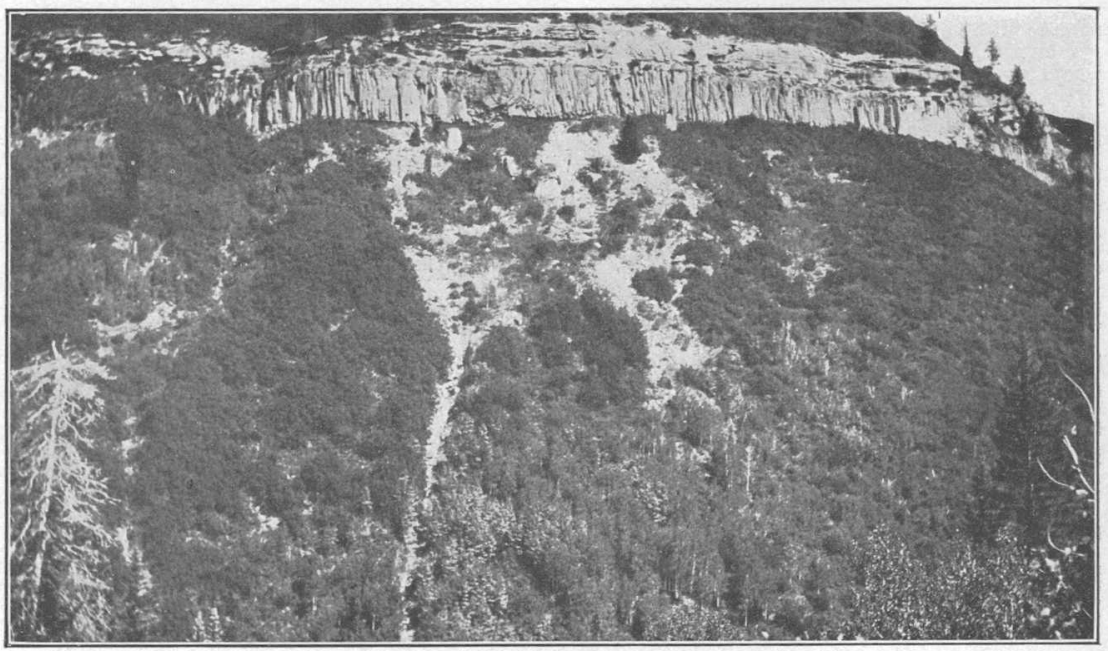

A. AN INTRUSIVE SHEET OF IGNEOUS ROCK IN COAL CREEK CANYON THAT HAS METAMORPHOSED THE UNDERLYING BED OF COAL.

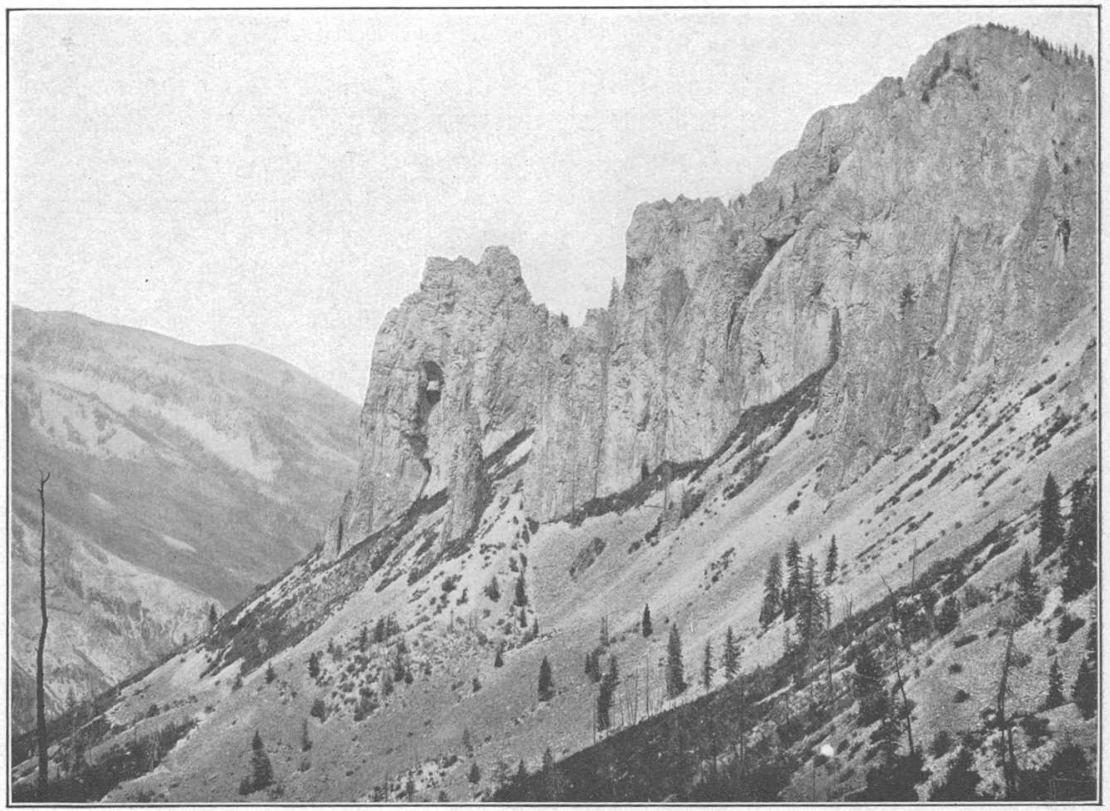

B. THE CLIFF, A SHEET OF IGNEOUS ROCK, ABOUT 1,000 FEET THICK, INTRUDED INTO THE COAL-BEARING FORMATION IN COAL CREEK CANYON. (SEE PL. VIII, A.)

Coal Creek canyon and Mount Gunnison appear at the left. The outcrops of the coal are covered by the slide rock shown in the foreground. (Scale: The trees in the face of the cliff are about 50 feet high.) 
it to act as a stiffly viscous mass. Two sections of the same beds were measured 500 feet apart, and the results are shown in figure 17, page 126. In this short distance the highest bed thinned from 41 inches in section $B$ to 19 inches in section $A$. The next lower bed of $\mathrm{B}$ was not found in $\mathrm{A}$, and the lowest bed, which in section $\mathrm{A}$ has a thickness of 7 feet of coal with three distinct partings, shows no partings in section $B$ and has a thickness of 8 feet 2 inches of coal.

This variation in thickness due to rock movement may also explain some of the greater differences in the occurrence and thicknesses of certain coal beds at localities separated by considerable distances-differences which otherwise would seem to be attributable to conditions of deposition. Thus at locality No. 61 just described the lowest coal bed is 59 feet above the top of the Rollins sandstone, but the shale near the base is black and carbonaceous. At locality No. 69, in Wadsworth Canyon only $3 \frac{1}{2}$ miles from locality No. 61, a coal bed resting on this sandstone contains 15 feet 8 inches of coal. Unfortunately the beds can not be followed continuously along the outcrop in this district, and it was not determined whether this and other variations similar to it are due to original deposition or are due in some measure to rock movements.

In this district, although there are massive sandstone layers within the coal-bearing rocks, the coal occurs mainly in beds of soft shale that underlie an extensive series of cliff-making sandstones, which outcrop in the steep walls of the canyon. (See Pl. VIII, B). The rock débris from the cliffs covers the outcrops of coal-bearing shale in many places. Where the canyon sides are not too steep, they are generally covered with a dense growth of brush, and in the relatively few places where exposures occur, the rocks are commonly found more or less displaced by a downward creep of the surface rocks, which in some places results in landslides, one of which is shown in Plate X, page 128. For these reasons it was found impracticable to traverse individual beds of coal and to open them at stated intervals. There are long distances along the outcrop between prospects in which no coal was seen, in spite of the fact that probably all of the coal beds of the district are present under the surface cover. In some cases the position and character of the coal beds might be determined by a shallow trenching of the canyon side, but it is believed that the only practical method of-prospecting in many places is by means of the diamond drill.

In many places where coal was found at the outcrop, it is crushed, and the thickness of the bed is changed by the surface creep of the rocks. In some places the slide rock has removed the top of the coal, so that only a part of the original bed is seen. In other places the slide rock has accumulated so thickly over the coal beds that it $40642^{\circ}-$ Bull. $510-12-8$ 
was impracticable to run a prospect opening in to the solid coal. Few satisfactory measurements were made, except where streams or landslides had removed the loosened surface material and exposed the coal in undisturbed beds.

There is no place in the Coal Creek district where a complete geologic section of the coal-bearing rocks can be measured. Eight short sections were measured and the results are shown graphically in figure 15, page 119. The numerals at the top of the columns refer to localities with corresponding numerals on the accompanying map, at which the sections were measured. Certain horizon markers, such as prominent sandstone cliffs and a bed of oyster shells, served as satisfactory means for the general correlation of the sections, but the correlations of the coal beds shown in these sections are subject to correction, as more data are obtained. Since most of the shale slopes in which the coals outcrop are covered with brush and slide rock, some of the coal beds may have escaped detection. In the one locality (see fig. 15, section No. 64, p. 119), at which the rocks between coal beds No. 4 and No. 5 are exposed, no coal was found through a thickness of 158 feet. If this barren zone is persistent throughout Coal Creek district, it is difficult of explanation in view of the fact that the sections measured in the Somerset district only a few miles northwest show no such barren zone. The stratigraphic position and probable correlation of all of the commercially important coal beds known to occur in the Coal Creek district are shown in figure 15, page 119, and will be referred to by number in order from base upward.

The rock formations are the same as those described for the districts on the west. The Mancos shale, the lowest formation exposed, outcrops in the southern part of the district, and isolated exposures of it are found around Mount Gunnison, but little attention was given to it in this district. The Rollins sandstone was identified in many places by means of its characteristic fossils, especially the supposed seaweed Halymenites major Lesq., and served as a convenient horizon marker. The Bowie shale is characteristically developed and contains the marine and brackish water shells that are abundant in the rocks of this member in the Somerset district. Also the Paonia shale or coal-bearing fresh-water member of the Mesaverde is here represented, but the line of demarkation between the two is not so clearly defined as it is in the districts farther west. The highest coal bed contains relatively soft coal, is associated with fossil plants and fresh-water shells, and clearly belongs in the Paonia shale. The sandstone cliff below this bed is prominent and persistent like a sandstone which in the Somerset district is similarly placed, and which is the highest part of the Bowie member, but no marine shells were found in it in the Coal Creek district. Most of the coals below this sandstone are harder than the coal of the highest bed and in 
quality and character resemble the high-grade bituminous coals of the Bowie member in the Somerset district, but the local metamorphism of the coals in the Coal Creek district renders their physical and chemical characters unsafe criteria for correlation. For these reasons no line of separation between the Bowie and Paonia members of the Mesaverde has been drawn in the columnar sections in figure 15 , page 119 , and the boundary line between them on the map is only approximate and is subject to change.

Rocks of the undifferentiated part of the Mesaverde occur in the Coal Creek district and in the northern part of this district are present in full thickness. The massive sandstones form the precipitous cliffs and steep canyon walls and are the chief cause of the striking topographic features that occur between Mount Beckwith and Somerset. The Ohio Creek conglomerate also is present in the northern part of the district and, together with the basal conglomerate of the Wasatch formation, forms the gently sloping stratum plains that constitute the tops of the mesas. The Wasatch formation contains the youngest sedimentary rocks of the district. They are not known to be of economic importance, and little work was done on them or on the igneous intrusives netr Coal Creek.

With the exception of the lowest coal, or bed No. 1, the coal beds of Coal Creek district are apparently regular enough in occurrence to warrant the inference that they are continuous throughout the district rather than lenticular, as the beds farther west are supposed to be. Coal No. 1, although very thick in Wadsworth Canyon at locality No. 79 , was not found in some places where the rocks are well exposed, and. in other places is represented only by carbonaceous shale. As already described, its absence from some places may be due to rock movements, but the coal is believed to be essentially a local deposit.

Coal bed No. 2 was found wherever the rocks are exposed well enough to show their contents. It occurs about 60 feet above the base of the coal measures and a few feet above a bed of oyster shells that can usually be identified wherever the rocks are moderately well exposed. The bed varies in thickness from 13 feet 5 inches at locality No. 61 (see fig. 11) to 1 foot 1 inch at locality No. 68. This great variation in the thickness of the bed suggests that it may be lenticular and places may yet be found where it does not occur.

Coal bed No. 3 occurs a few feet above coal No. 2 and was identified at four localities (see fig. 12). It is believed to occur elsewhere in Coal Creek district, but few places were found where the rocks at this horizon are exposed. So far as known its thickness ranges from 1 foot 4 inches to 7 feet 6 inches. Coal bed No. 4 occurs closely associated with coals Nos. 2 and 3, and the three together form a well-defined coal group. 
No coal was found for a distance of 168 feet above coal bed No. 4 . But only one place was found in Coal Creek district where the rocks are well exposed in this zone, and in view of the fact that no such barren zone occurs in rocks of the same age in the Somerset district probably coal will yet be found in some places within it. Coal No. 5 was opened at three localities (see fig. 12), and its presence in several other places is indicated by "blossom" in the hillsides at horizons where this bed should occur. The general impression gained from. field observations is that this bed is very regular in occurrence, and that it is one of the most important beds of coal in the Coal Creek district.

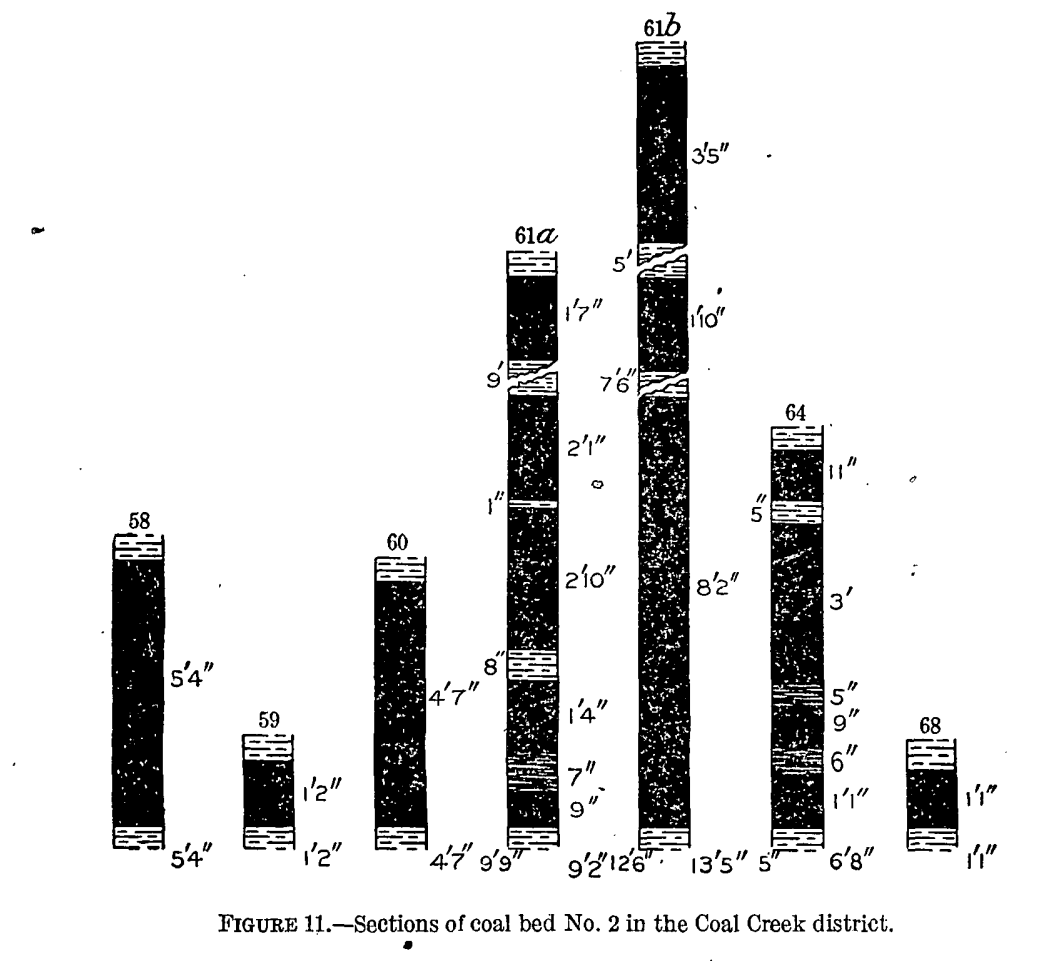

Coal No. 6 has probably been prospected in more localities than any other bed in this district.' It is a thick bed of hard coal, usually clean (see fig. 13), and has been called splint coal by some and anthracite by others, but although harder than other coals of this district, the bed contains anthracite coal only where it has been metamorphosed by intrusive igneous rock (see fig. 15, p. 119). The coal bed appears to be persistent throughout the district and to maintain a greater uniformity in thickness than other coals of the Grand Mesa field.

Comparatively little is known of coal No. 7. It was opened at locality No. 52, where it is 2 feet thick, and at locality No. 57, where 
it is somewhat thicker than 2 feet. At locality No. 64 it is 2 to 3 feet thick. The bed is 4 to 15 feet above coal No. 6 and possibly should be considered as a bench of No. 6 coal, but because of its distinctness from this bed in the few places where the rocks are well exposed it is here regarded as a separate bed (see fig. 15, p. 119).

Coal No. 8 is probably the most persistent bed in the Coal Creek district, but occurring as it does in soft shale good exposures of it are scarce. It was opened at only four localities (see fig. 14), but its presence was noted by "blossom" in many places throughout the Coal Creek district, and it is believed that the four sections plotted in this figure adequately represent the bed. It is a relatively soft, coking, bituminous coal, and so far as observed is free from impurities other than thin partings of shale.

\section{DESCRIPTIONS OF LOCALITIES.}

Coal Creek district is far from centers of habitation, and there are few place names that can be used in describing localities. In the absence of location names, numerals will be used to designate places at which sections were measured and coal prospects examined.

According to S. L. Mosley, a 6foot bed of coal was opened several years ago high in the west side of Coal Creek canyon in sec. 28, T. 13 S., R. $89 \mathrm{~W}$., of the land net as projected on the accompanying map. The old prospect could not be found at the time of investigation, nor was any indication of coal seen; perhaps
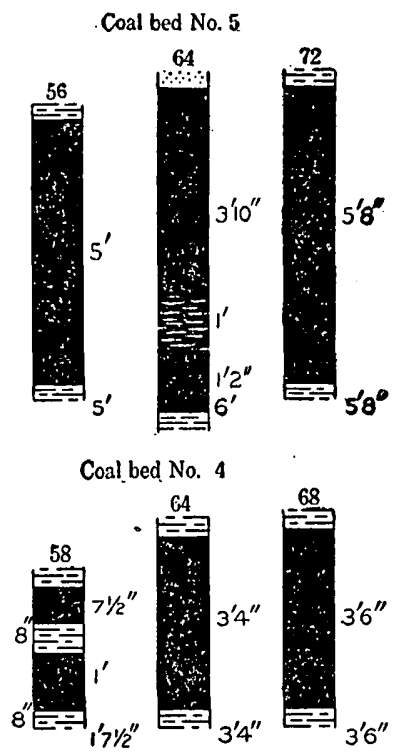

Coal bed No. 3

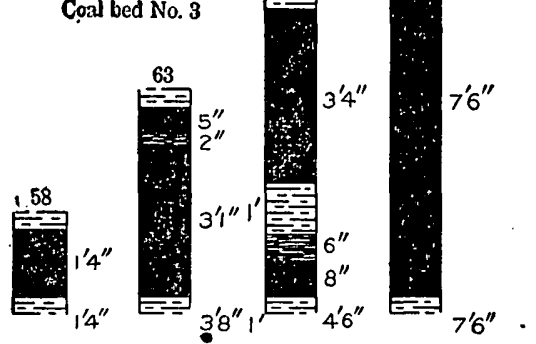

Figure 12.-Sections of coal beds Nos. 3,4 , and 5 in the Coal Creek district. because of the dense growths of brush that cover the sides of the canyon. Apparently this bed is at a much higher horizon than any of the coals that have been opened in the Somerset or Coal Creek districts and may be the same bed as that observed high in the Mesaverde formation in the canyon of Hubbard Creek.

Locality No. 49.-The northernmost exposure of coal found in Coal Creek district is in see. 33, T. 13 S., R. 89 W., of the projected land 
net in the bed of Coal Creek, at locality No. 49. The bed, although somewhat disturbed by slide rock, is sufficiently well exposed to

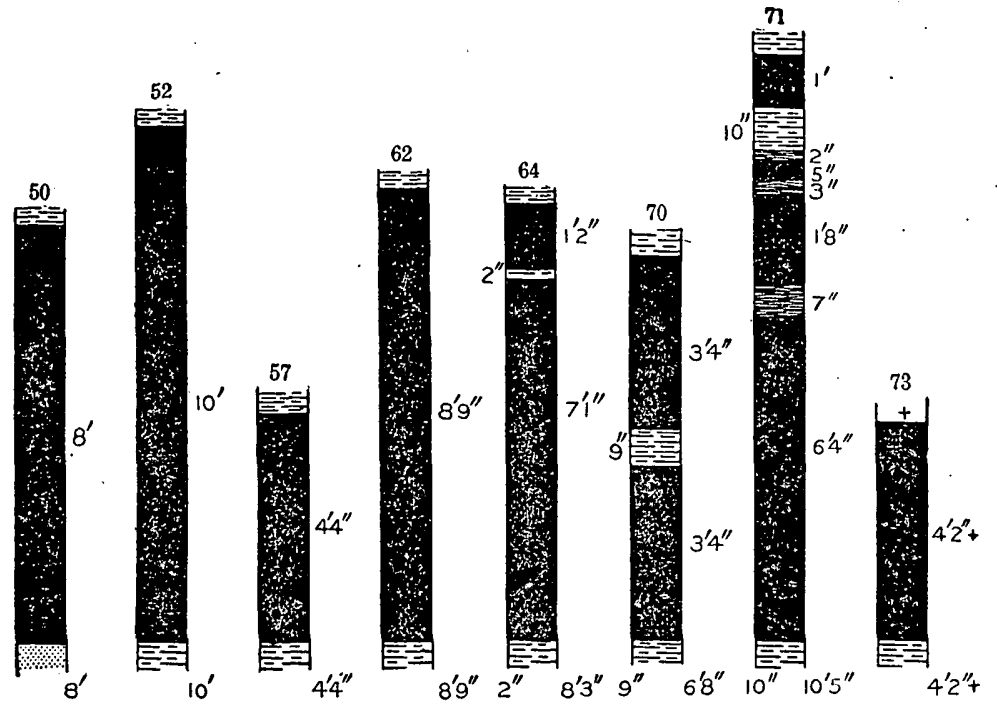

Figure 13.-Sections of coal bed No. 6 in the Coal Creek district.

indicate a thickness of $\overline{6}$ feet or more where the coal is not disturbed. The bed is associated with fossil plants and fresh-water invertebrates

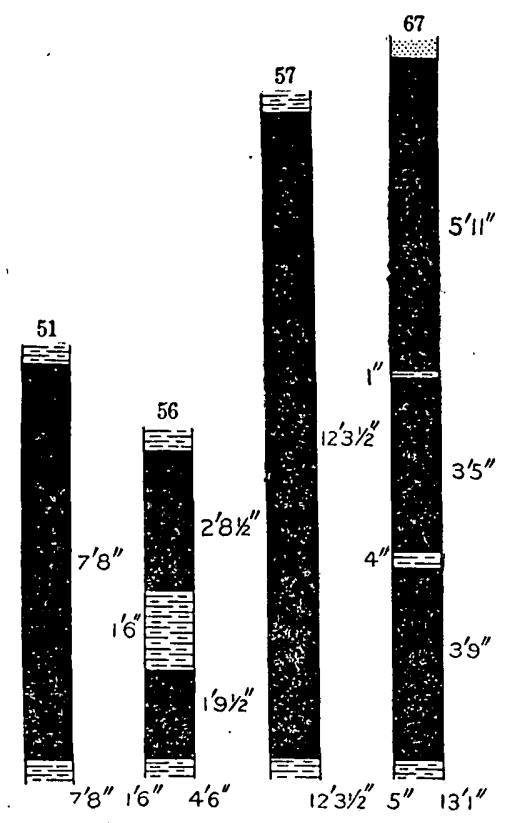

FIgURE 14.-Sections of coal bed No. 8 in the Coal Creek district. and is one of the Paonia or freshwater coals. The bed is possibly the northward continuation of the thick bed in Coal Creek canyon and designated as coal bed No. 8 , but its stratigraphic position can not now be fixed definitely. The northward dip of the rocks near Coal Creek is greater than the gradient of the stream, and the coal bed passes beneath the surface north of this locality. Toward the south. the outcrop of the coal bed rises in the canyon walls, but it can not be traced for any considerable distance because of brush and slide rock which cover the coal.

Mr. Mosley states that a coal bed was opened several years ago in the canyon of Little Gunnison Creek, but the prospect was not found at the time of investigation. In the east side of Coal Creek canyon opposite the mouth of Little Gunnison Canyon, coal "blossom" was found at several horizons above the 
lowest fresh-water coal in rocks containing fossil plants, and it is believed that higher coal beds will yet be found there.

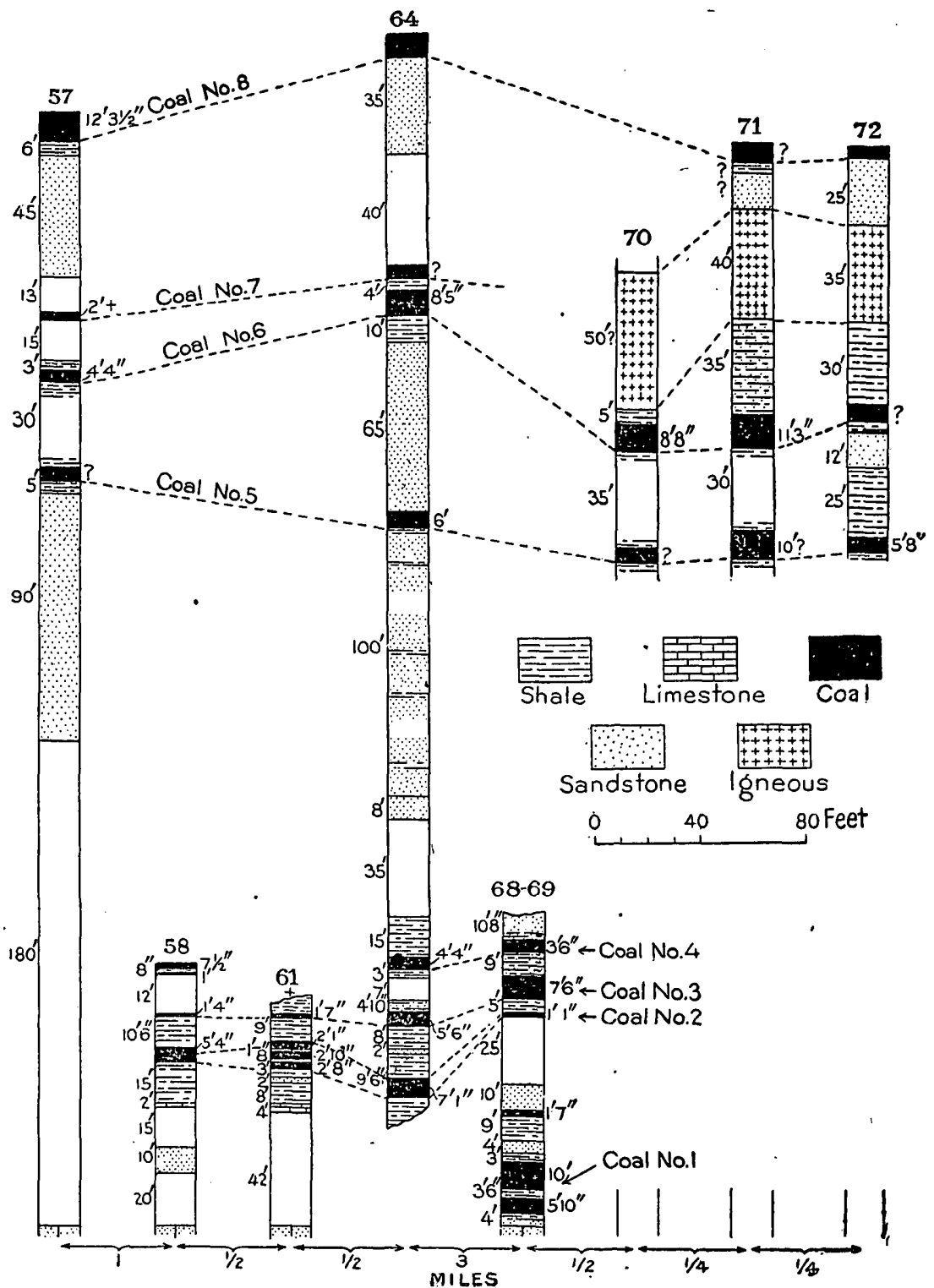

FIgURE 15.-Columnar sections measured in the Coal Creek district showing the occurrence and correlation of the coal beds.

Locality No. 50.-A bed of coal was opened several years ago at locality No. 50, in the east wall of Coal Creek canyon. A small exposure of the rocks here shows the succession as follows: 
Oyster shells and shark teeth were found in the rocks about 50 feet above the mine and prove that the two coal beds are in the Bowie member of the Mesaverde. The sandstones above the 2-foot bed are those that underlie the fresh-water coal at locality No. 51, although no surface indications of this highest bed could be found above the Mosley mine.

Although the sandstones at the top of this section are somewhat shaly, they probably represent the 45-foot sandstone below No. 8 coal at locality No. 57 in the opposite side of the canyon, the nearest place at which a section of the rocks was measured. (See fig. 15, section 57, p. 119.) Furthermore the mine is at the horizon at which coal bed No. 6 should occur. 'Its position 12 feet below a thin bed of coal corresponds to the position of No. 6 coal in section No. 57, which is 15 feet below a 2-foot bed. For these reasons the bed at the Mosley mine is provisionally classed as coal No. 6 and the bed 12 feet higher as coal No. 7 .

The coal from this mine has been used locally for several years, a few tons being mined each year, and the entry has been driven in on the coal bed about 60 feet. At the outcrop the bed is 10 feet thick, and the roof and floor consist of shale. The bed is said to be 7 feet thick in the mine where coal was last removed. The coal is hard, dull black in color, vitreous in luster, fine grained even to seamy in texture, with conchoidal fracture, free from bone, does not slack on exposure to the weather, and cokes readily in the open fire. The coal has been called anthracite because of its hardness, but analysis shows that it is bituminous coal with a percentage of fixed carbon even lower than that of some of the bituminous coals of the Somerset district that are much softer. (See analysis No. 5344, p. 205.) The Mosley coal apparently has been affected by heat derived either from the igneous rock of Mount Gunnison or from friction caused by disturbances of the sedimentary rocks due to the intrusion of the mountain mass?

A sample of the coal from the Mosley mine was taken for analysis from a freshly cleared face 60 feet from the mouth of the mine and includes the upper 7 feet of the coal. The results of the analysis are given as No. 5344 of the table of analyses on page 205 .

Locality No. 53.-The next exposure of coal in order southward was found at locality No. 53, on the slope of Mount Gunnison, in sec. 15 , T. 14 S., R. 89 W., of the projected land net, at an altitude of about 8,000 feet. The coal measures are upturned steeply against the igneous rock (strike N. $38^{\circ} \mathrm{W}$.; dip $80^{\circ}$ E.) but are so covered with brush and slide rock, except where a stream has removed the débris, that only a short section could be measured, as follows: 
Section of coal-bearing rocks measured east of Mount Gunnison in sec. 15, T. 14 S., R. 89 W.

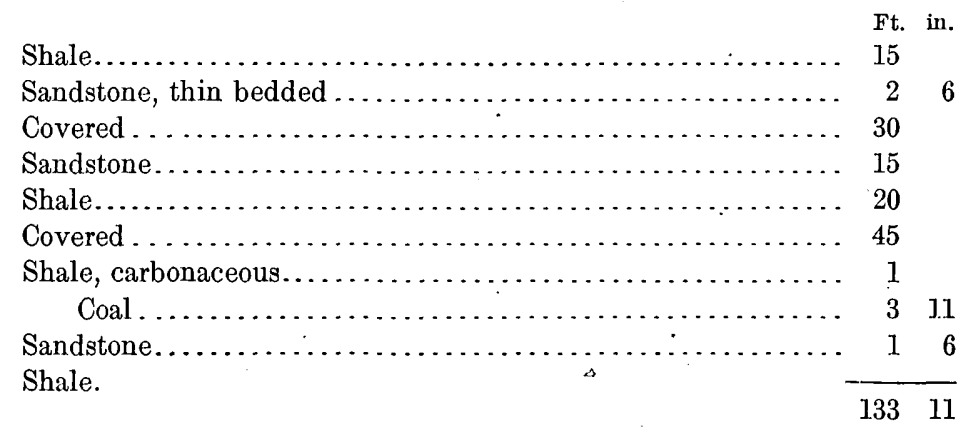

The coal is clean and hard like that from the Mosley mine. No other coal beds were found at this locality, and there is nothing to indicate the geologic horizon of the one appearing in the section given.

Locality No. 54.-In the same gulch, in section 15 of the projected land net, at locality No. 54, an old prospect was found with an entry run in 30 feet on the coal bed. The coal is near the base of the coalbearing rocks, but nothing was found by which its exact horizon could be determined. The rocks strike N. $8^{\circ} \mathrm{W}$. and dip $10^{\circ} \mathrm{W}$.

Section of coal bed measured in Coal Creek canyon in sec. 15, T. 14 S., R. 89 W.

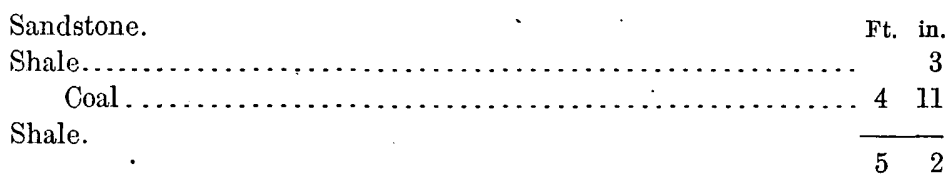

Locality No. 55.-The next place toward the south at which coal was found is in the west wall of Coal Creek canyon, at locality No. 55 . The basal sandstone (Rollins) is exposed near this locality, and the oyster bed, which in other places is about 45 feet above the top of

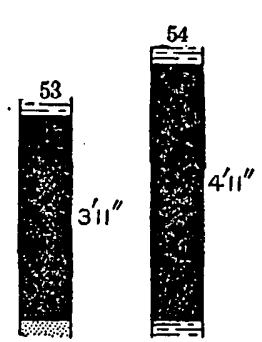

FIGURE 16.-Sections of coal in prospects in the Coal Creek district. this sandstone, was found. Four feet above the oyster bed 6 inches of hard coal was found. The imperfectly exposed rocks above this coal are black and carbonaceous, but no coal was found in them, although at this same horizon about 1 mile farther south, at locality No. 61, coal occurs nearly 9 feet thick. Nothing was found to indicate whether the absence of a thick bed of coal at this place is due to nondeposition or is attributable to some other cause.

South of this locality coal-bearing rocks occur for only a short distance west of Coal Creek, the sedimentary rocks having been eroded from the side of Mount Gunnison, but they appear in full thickness in the east side of the canyon. The rocks dip $24^{\circ} \mathrm{NE}$. and strike N. $75^{\circ} \mathrm{W}$. 
Locality No.56.-In the east wall of Coal Creek canyon, at locality No. 56, coal bed No. 8 was opened and the following section was measured:

Section of coal bed No. 8 in Coal Creek canyon in sec. 14, T. 14 S., R. 89 W.

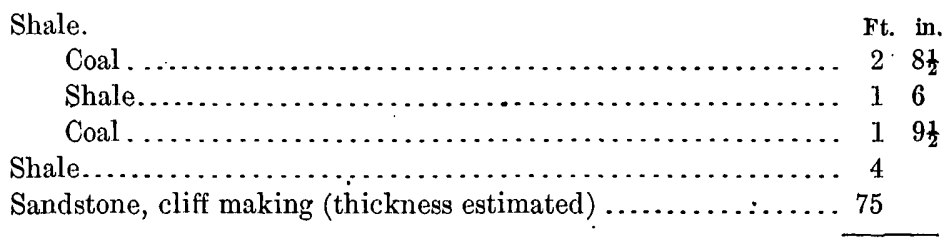

85

Beds No. 6 and No. 7 were not found in this locality, but coal "blossom" was observed on the slope near the horizons at which they probably occur. Coal bed, No. 5 was found above a sandstone cliff and opened. The following section was measured in this opening:

Section of coal bed No. 5 in Coal Creek canyon in sec. 14, T. 14 S., R. 89 W.

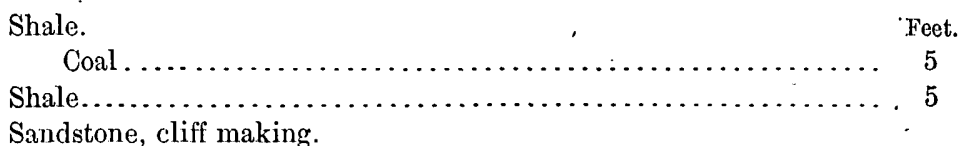

The coals were too much weathered at this locality to give a satisfactory indication of their character.

The sandstone cliff's below coal beds No. 5 and No. 8 were followed from locality No. 56 northward to Cliff Creek, and coal "blossom" was observed at several places, but no place was found favorable for opening the coals. In Cliff Creek canyon the rocks at the horizon of coal bed No. 8 are well exposed but are.reddened by the burning of the coal. The lower beds are not exposed at the mouth of this canyon, and no coal was found, although beds No. 6 and No. 7 are to be expected in the canyon walls and probably extend up the creek half a mile or more from its mouth before passing beneath water level.

A bed of good bituminous coal 2 feet 5 inches thick is reported about half a mile from the mouth of Cliff Creek, at the locality indicated on the accompanying map by a cross, at a horizon that suggests the presence of coal bed No. 8 , but no details were learned regarding it.

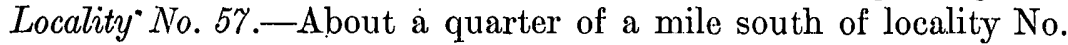
56 , the northward dip of the rocks carries the base of the coal measures beneath the surface. The lower 300 feet of coal-bearing rocks are covered with brush and rock débris, and no details of this part of the section were obtained; but at locality No. 57 in sec. 14, T. 14 S., R. 89 W., of the projected land net, a short section was measured with the following results: 
Section of rocks measured in the east wall of Coal Creek cainyon.

[For graphic section see fig. 15, No. 57, p..119.]

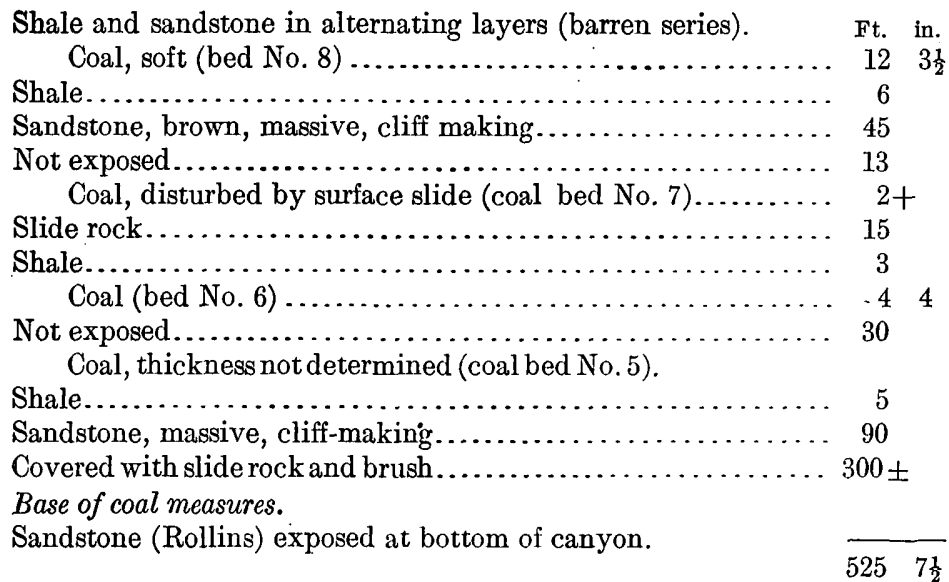

No coal was found above the highest bed (No. 8) of this section, although the sedimentary rocks are relatively well exposed through a thickness of several hundred feet. Fragmentary remains of fossil plants were found near the highest coal bed, which, together with the softness of the coal and its general resemblance to the Paonia coals of the Somerset district, indicates that this bed belongs to the Paonia member of the Mesaverde. The cliff-making sandstone below this coal is similar in character and stratigraphic position to the highest sandstone in the Somerset district that yields marine fossils, but no fossils of any kind were found in it. On the other hand, the cliffmaking sandstone below No. 5 coal may mark the top of the Bowie member, but this is rendered doubtful by the character of the coal of beds $N_{0 .} 5$ and No. 6, which is harder than that of No. 8 and resembles - the Bowie coals more closely than it does those of the overlying beds of fresh-water origin. The thickness of coal No. 7 was not determined at locality No. 57 because of the covering of débris and because of the surface creep of the rocks that had displaced the coal near the outcrop. A thickness of 2 feet of crushed coal was found, but the unchanged bed may be thicker. The general tendency of the creep is to elongate the bed and diminish its thickness. The 52-inch bed, No. 6 of the section, was well exposed, and the full thickness was measured in a prospect opening. No measurement could be made of coal No. 5 at this locality because of a covering of slide rock, but at locality No. 56 , half a mile north, this bed is 5 feet thick. The coal is harder than that of the highest bed, but no definite evidence was obtained to show whether it belongs to the sedimentary rocks of fresh-water origin-Paonia member of the Mesaverde-or to those of brackish water and marine origin-Bowie member of the Mesaverde.

Locality No. 58. - In the east side of Coal Creek canyon about half a mile south of No. 57 , at locality No. 58 , in sec. 23 , T. 14 S., R. 89 W., 
of the projected land net, a landslide has exposed the rocks near the base of the coal measures, and the following section was measured:

Section of coal-bearing rocks measured in the east wall of Coal Creek canyon.

[For graphic section see fig. 15, No. 58, p. 119.]

Shale, above which surface is brush covered.

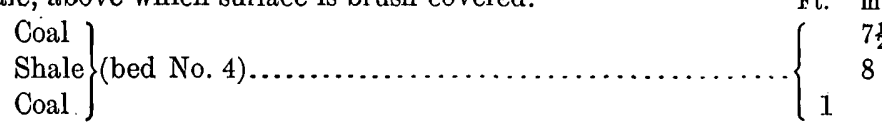

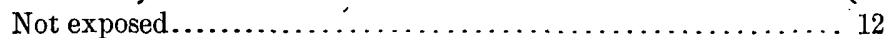

Coal (bed No. 3) ............................. 14

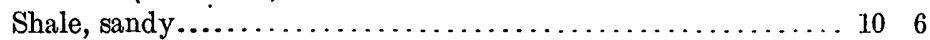

Coal (bed No. 2) .............................. 54

Shale and sandstone in alternating layers................. 15

Limestone, sandy, contains Ostrea sp., Anomia sp., Modiola sp., Corbicula sp.................................. 2

Not exposed..................................... 15

Sandstone, massive, white.......................... 10

Not exposed................................... 20

Base of coal measures.

Sandstone (Rollius) containing Halymenites major Lesq. and marine invertebrates.

No evidence of coal was found at this locality on the covered slope above the Rollins sandstone at the horizon where coal bed No. 1 occurs in Wadsworth Canyon (locality No. 69), and its absence from locality No. 61, where the rocks are perfectly exposed, indicates that this coal bed is not to be expected at locality No. 58 .

A coal bed 62 feet above the base of the coal measures was prospected several years ago, and the old entry was open for a distance of about 15 feet at the time of investigation. The beds are upturned at the surface; the dip being $15^{\circ}$ due east, whereas at the end of the prospect, the dip is only $8^{\circ}$. The coal is clean and hard and is locally known as semianthracite. It is probably the hard variety of bituminous coal described from the Mosley mine, locality No. 52. The thinner coal beds near the top of the section (Nos. 3 and 4) were opened and the coal was found to be similar in quality to that of the lower bed (No. 2).

Locality No.59.-Coal bed No. 2 was found at locality No. 59 , in the east side of Coal Creek canyon, in sec. 23, T. 14 S., R. 89 W., of the projected land net, about half a mile south of locality No. 58. The basal or Rollins sandstone and about 70 feet of the overlying coal measures are exposed at this place. The oyster bed, which was observed in several places on Coal Creek 45 feet above the base of the coal measures, is here 4 feet thick. Coal bed No. 2 is 60 feet above the top of the Rollins sandstone and is exposed in an old prospect, where a thickness of 1 foot 2 inches of bright clean hard coal was found resting on a shale floor and overlain by carbonaceous shale. No 
indications of the lowest coal bed (No. 1) were found, and probably it does not occur at this locality.

Locality No. 60.-At locality No. 60, in sec. 23, T. 14 S., R. 89 W., of the projected land net, the Rollins sandstone is exposed near the bottom of the canyon, and the oyster bed is 45 feet above it. Coal

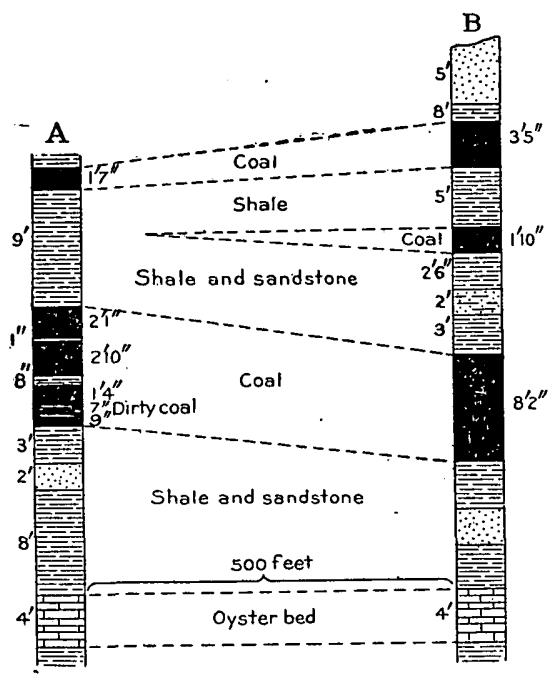

FIGURe 17.-Sections of coal beds in Coal Creek canyon, showing differences in thickness due to rock movements. bed No. 2 is 60 feet above the top of the Rollins sandștone and has a thickness of 4 feet 7 inches of coal with shale above and below it. The coal is clean, hard, and bright, and although locally called anthracite it is probably the hard variety of bituminous coal described from the Mosley mine, locality No. 52. None of thehigher beds was found at this locality, probably because of the brush and the rock débris that cover the sides of the canyon.

Locality No.61.-In order toward the southwest the next exposure of coal found is at locality No. 61 , in sec. 27 , T. 14 S., R. $89 \mathrm{~W}$., of the projected land net, in a side gulch entering Coal Creek canyon from the slope of Mount Gunnison. The basal sandstone and the lower 80 feet of the coal measures are well exposed in this gulch, and the following two sections, $A$ and $B$, were measured. These sections and the interrelations of the coal beds are shown graphically in figure 17 .

Sections of coal-bearing rocks measured east of Mount Gunnison.

[For graphic section see fig. 15, No. 61, p. 119.]

Shale.

Section A.

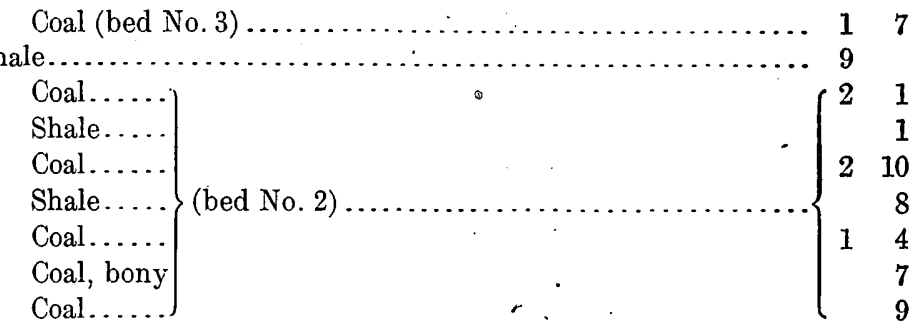

Shale............................... 3

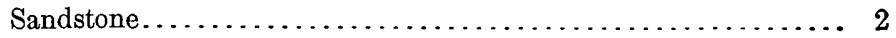

Shale................................... 8

Limestone, contains Ostrea sp., Anomia sp., Corbicula? sp..... 4

Sandstone and shale, alternating layers............... 42

Base of coal measures.

Sandstone (Rollins). 
Section B, 500 feet farther up the gulch.

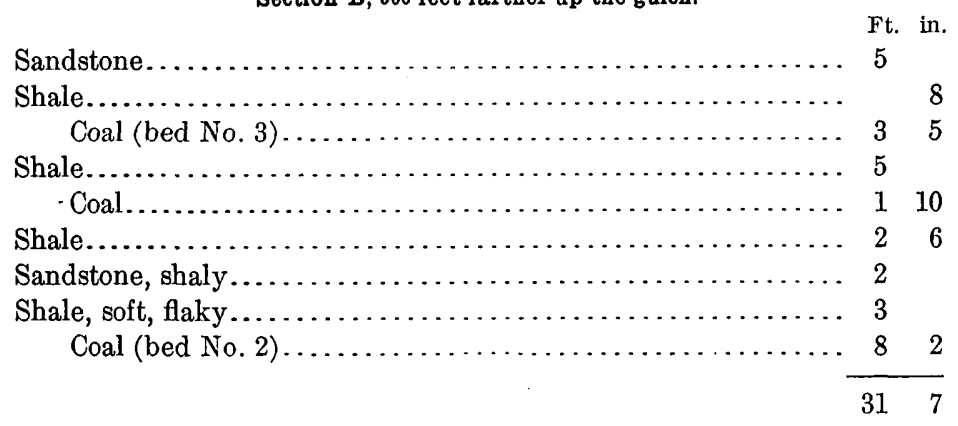

The rocks are steeply upturned against the side of Mount Gunnison (strike N. $20^{\circ} \mathrm{E}$; dip $35^{\circ} \mathrm{SE}$.), and the higher beds are eroded. The upturned beds are truncated by erosion, and their outcrop could probably be followed uninterruptedly around the south side of Mount Gunnison were it not for the accumulations of slide rock from the mountain side, which cover the sedimentary rocks near the foot of the mountain south and west of this locality. The upturning of the coal measures both north and east of Mount Gunnison, and the occurrence of large blocks of the coal-bearing rocks high in the mountain carried up by the igneous rock is regarded as sufficient proof that the Mount Gunnison mass was thrust up through the coal measures rather than intruded into rocks above the coal, as was the Cliff and probably also Mount Beckwith. In other words, at no place are the coal beds known to extend under Mount Gunnison, and from the observed relations the inference is drawn that the coal beds do not underlie any part of the mountain mass.

The coal at locality No. 61 is considerably crushed and slickensided, and apparently the original thicknesses of the beds are somewhat changed, as was described in the general statement, page 113. The coal is a hard, bright, clean semianthracite changed from a bituminous coal by the metamorphic action of the igneous rock of Mount Gunnison, and the same beds farther from the disturbed area contain bituminous coal.

Coal bed No. 1 is not represented in this locality, but its place in the section is occupied by dark-colored shale. The lowest coal of the section, occurring as it does a few feet above the oyster bed, is obviously coal No. 2 , and the higher bed is coal No. 3 .

Locality No. 62.-Although no exposures of coal were found at the base of Mount Gunnison south and west of locality No. 61, several beds were opened along the upper parts of Coal Creek and its tributaries, which have cut canyons into the coal measures. The first of these prospects above the mouth of Robinson Creek was opened in sec. 27 , T. 14 S., R. 89 W., of the projected land net, in the south wall of Coal Creek canyon, at locality No. 62. The canyon side is covered 
with brush and a section of the rocks could not be measured. The probable stratigraphic positions of the coal beds that were found were determined by correlation with the section measured at locality No. 64. Coal bed No. 8 was identified by the presence of crushed and weathered coal above a prominent sandstone cliff at an altitude of about 8,000 feet, but the bed was not opened.

At a horizon about 90 feet below coal bed No. 8 (due állowance being made for dip), a coal bed, probably No. 7, was found. The coal is crushed and displaced to some extent by surface movement, but the quantity of coal found at the outcrop indicates the presence of a bed at least 3 or 4 feet thick.

About 35 feet lower a bed that is probably coal No. 6 was opened, and a thickness of 8 feet 9 inches of clean coal was found resting on cabonaceous shale. No undisturbed roof material was found, and the creep of the surface débris had carried away some of the coal from the top of the bed: This coal was prospected several years ago by S. L. Mosley, who states that the unweathered coal will coke. Mr. Mosley also states that he opened three coal beds in the east wall of the gulch opposite locality No. 62. At the level of coal bed No. 6 he reports a thickness of about 3 feet of coal. He found coagl beds No. 7 and No. 8 at the horizons indicated in the section given on page 129 , which was measured at locality No. 64 , but no satisfactory measurements were obtained of those coals, and the old prospects were inaccessible at the time of investigation.

Locality No. 63.-At locality No. 63, in the south wall of Coal, Creek canyon, an old prospect was found in which the following section of coal was measured:

Section of coal bed measured in south wall of Coal Creek canyon, sec. 27, T. 14 S., R. 89W.

Shale. Ft. in.

Coal

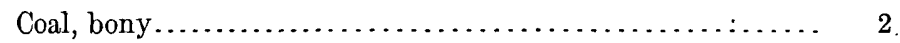

Coal. $3 \quad 1$

(Bottom not exposed.)

38

This coal is apparently the same as bed No. 3 of locality No. 64 about 500 feet southwest.

Locality No.64.- In the south wall of Coal Creek canyon, in sec. 27, T. 14 S., R. 89 W., of the projected land net, a landslide has exposed the coal-bearing rocks in an area where otherwise no section could be measured because of the forests that cover the canyon sides. (See Pl. X.) The section given on page 129 was measured at locality No. 64 . 


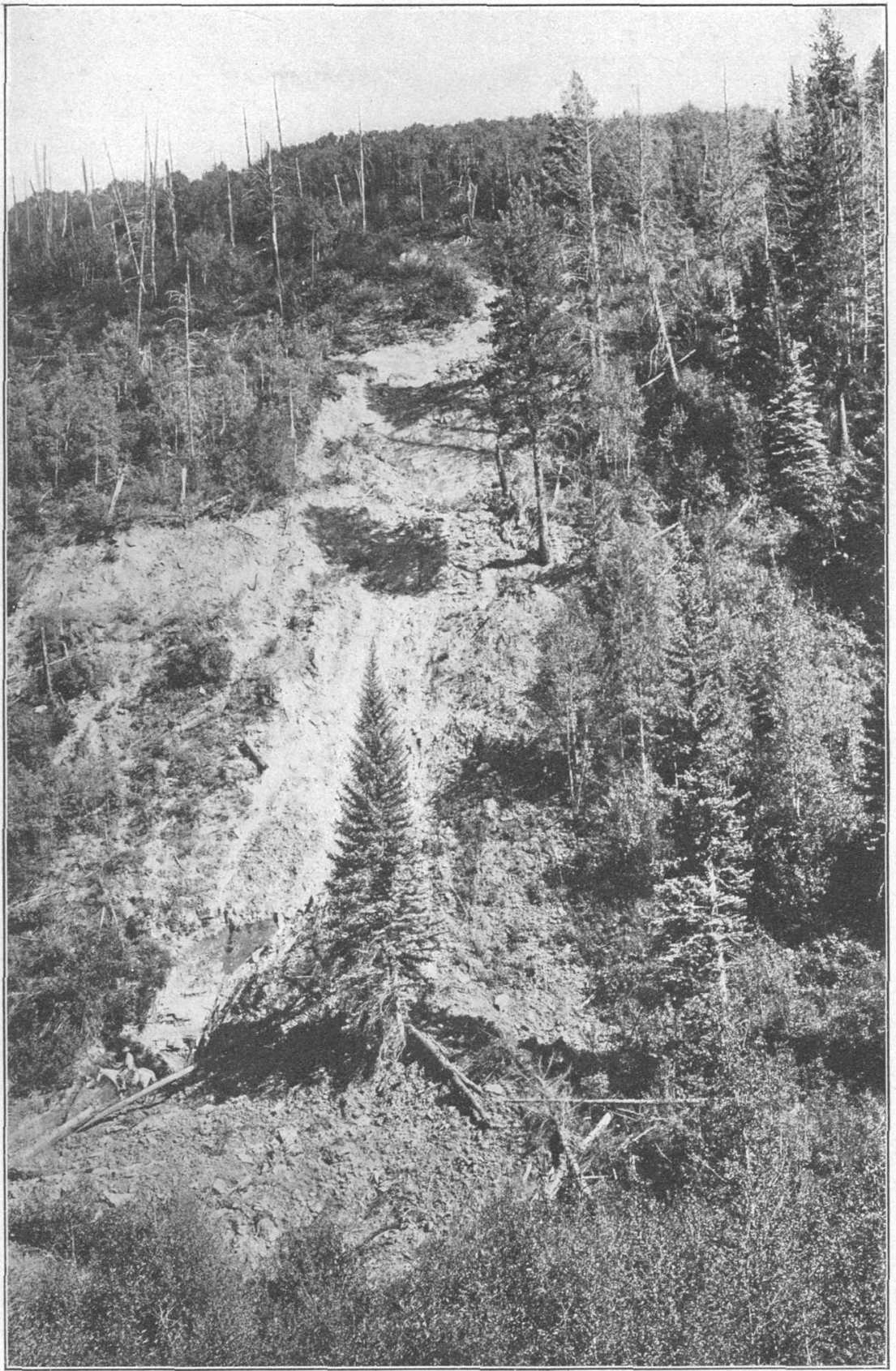

A LANDSLIDE IN COAL CREEK CANYON.

Showing the wooded condition of the surface in the coal-bearing zone. The coal beds, which eisewhere are obscured by dense thickets of trees and brush, are exposed at this slide. For section measured here see No. 64, figure 15. (Scale: See man on horseback at base of slide.) 
Section of coal-bearing rocks measured in Coal Creek canyon near the mouth of Robinson Creek.

[For graphic section see fig. 15, No. 64, p. 119.]

Shale with indications of coal bed No. 8 .

Sandstone, cliff making (thickness estimated)

Not exposed (thickness estimated)................... 40

Coal; slide indicates 2 or 3 feet of coal (bed No. 7).

Shale...................................... 4

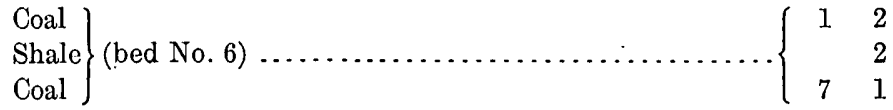

Shale....................................... 10

Sandstone, cliff making............................ 65

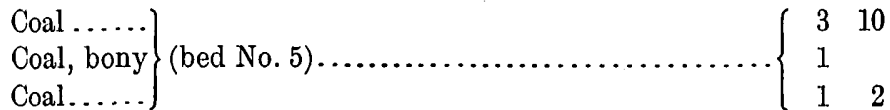

Shale.

Sandstone, with thin beds of shale, partly covered........... 100

Sandstone, cliff making................................ 8

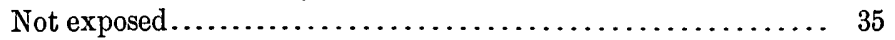

Shale.......................................... 15

Shale, carbonaceous............................... 1

Coal (bed No. 4) ............................ 3

Shale........................................... 3

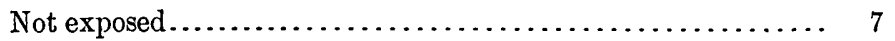

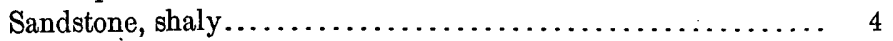

Shale......................................... 10

Coal............. $\quad\left[\begin{array}{ll}3 & 4\end{array}\right.$

$\left.\begin{array}{l}\text { Shale, carbonaceous } \\ \text { Coal, bony......... }\end{array}\right\}($ bed No. 3)...................

Coal...............

Shale.......................................... 8

Sandstone......................................

Shale........................................ 3

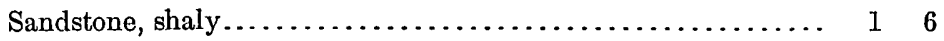

Shale.......................................... 5

Coal $) \quad[11$

Shale $\quad \begin{array}{r}11 \\ 5\end{array}$

Coal $\quad \cdot \quad \ldots$

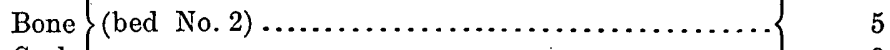

Coal

Bone

Shale.

The base of the coal measures is not exposed at this place. The oyster bed that occurs 45 feet above this base was not found, but its occurrence both east and west of this locality is sufficient evidence of its presence here and probably it will be found below the base of the exposed section. The lower three coal beds are undoubtedly near $40642^{\circ}-$ Bull. $510-12-9$ 
the base of the coal measures, and a comparison of this section with others measured in Coal Creek district (see fig. 15, p. 119) indicates that the lowest bed of the section is probably coal No. 2. Oyster shells found 200 feet above the base of this section prove that at least the lower three beds should be referred to the Bowie member of the Mesaverde formation, and the character of the three next higher beds, particularly coals No. 5 and No. 6, which are very hard, indicates that they too should be referred to this member. Fossil plants were found a few feet above the highest sandstone that is included in the section, and these together with the stratigraphic position of the highest coal bed found indicate that it is coal No. 8 and is properly referred to the Paonia member of the Mesaverde. But no clear line of demarcation can be drawn here between the two members.

All of the coal beds of this section except No. 8 were opened, and analyses were made of samples taken from the lowest bed or coal No. 2 (see No. 8800, p. 205) and from coal No. 5 (see No. 9142, p. 205). No. 2 coal is a good quality of bituminous and except for the partings of shale and bony coal is relatively free from impurity and is harder than the coal of many of the prospects of the Coal Creek district. Coals No. 3 and No. 4 of this locality do not differ materially in character from No. 2 coal.

Coal No. 5 occurs in the midst of massive sandstones about 200 feet thick, a fact which throws doubt upon the correlation of this bed with coal No. 5 of other localities, where No. 5 coal bed is associated with shale. But the bed is near the horizon at which No. 5 coal should occur, and the statement may well be reiterated here that the correlations of the coal beds of the various localities indicated by the numerals in the sections and shown by the correlation lines between the columns on figure 15 , page 119 , are provisional and made mainly for convenience of description. The impracticability of tracing the beds from one locality to another renders exact correlation quite impossible at the present time.

The sample, No. 8800, of coal from bed No. 2 was taken from a freshly cleaned face in a prospect opening and includes all of the coal, 5 feet 9 inches thick. The shale and bone partings were rejected. The sample, No. 9142, of coal from bed No. 5 was taken from a freshly cleaned face in a prospect 20 feet from the mouth of the opening and includes the 5 feet of clean coal exclusive of the 1 foot of bony coal. The results of the analyses are given on page 205 .

Locality No. 65.-Southwest of locality No. 64 the canyon sides are densely wooded and no coal was observed in them for a considerable distance, although it is probable that the beds are continuous beneath the surface covering. However, in the bottom of the canyon 
at an altitude of about 7,150 feet, in sec. 34, T. 14 S., R. 89 W., of the projected land net, coal was found in slide rock at locality No. 65 in quantities that indicate a bed 3 or 4 feet thick. Nothing was found to indicate the stratigraphic horizon at which this bed occurs.

Locality No. 66.-About 500 feet upstream from locality No. 65, but at a lower stratigraphic horizon owing to the dip of the rocks downstream; a bed of coal 2 feet 4 inches thick with shale below and sandstone above is exposed in the bed of the stream. The coal is clean but very hard and tough, and the stream has worn away the overlying sandstone leaving a projecting ledge of coal, which breaks off in large resistant blocks that are worn to rounded bowlders by the action of the stream. This is the hard bituminous coal that is locally called anthracite, and from this fact the inference is drawn that the coal is near the base of the coal measures-a horizon at which similar coals are found at other localities-but nothing further was found to indicate its position in the general section.

A sample of the coal was taken for analysis from the ledge exposed in the bed of the stream and includes the entire thickness. The results of the analysis are given as No. 9140 of the table of analyses on page 206.

Locality No. 67.-In sec. 34, T. 14 S., R. 89 W., of the projected land net, near the mouth of Apache Gulch, the highest bed or coal No. 8 was opened at locality No. 67 and the following section measured:

Section of coal bed in Coal Creek canyon, in sec. 34, T. 14 S., R. 89 W.

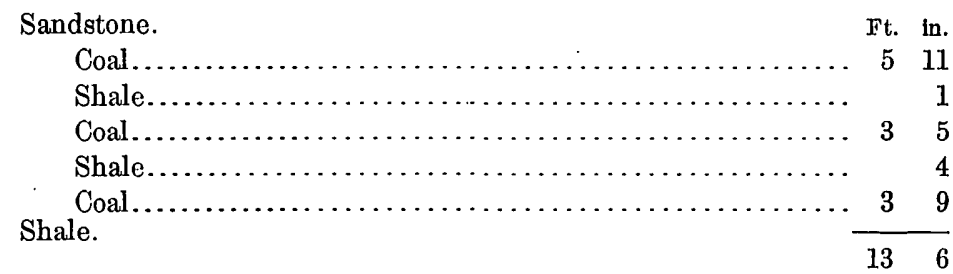

The coal is clean but relatively soft and is supposed to be a coking coal. No tests were made at this locality, but field tests on the same bed at other localities prove that the coal will make coke.

Localities Nos. 68 and 69.-In order upstream the next place at which coal beds were opened is in Wadsworth Canyon, in sec. 5 , T. 15 S., R. 89 W., of the projected land net, at localities Nos. 68 and 69. The sedimentary rocks are sharply upturned in this canyon (strike N. $45^{\circ}$ E., dip $23^{\circ} \mathrm{NW}$.), and short sections of the rocks are exposed including the Mancos shale, the basal or Rollins sandstone, and the lower part of the coal measures of the Mesaverde. The lowest bed of coal was examined at locality No. 69, the others at locality No. 68. 
The combined sections are as follows:

Section of coal-bearing rocks measured in Wadsworth Canyon, in sec. 5, T. 14 S., R. 89 W.

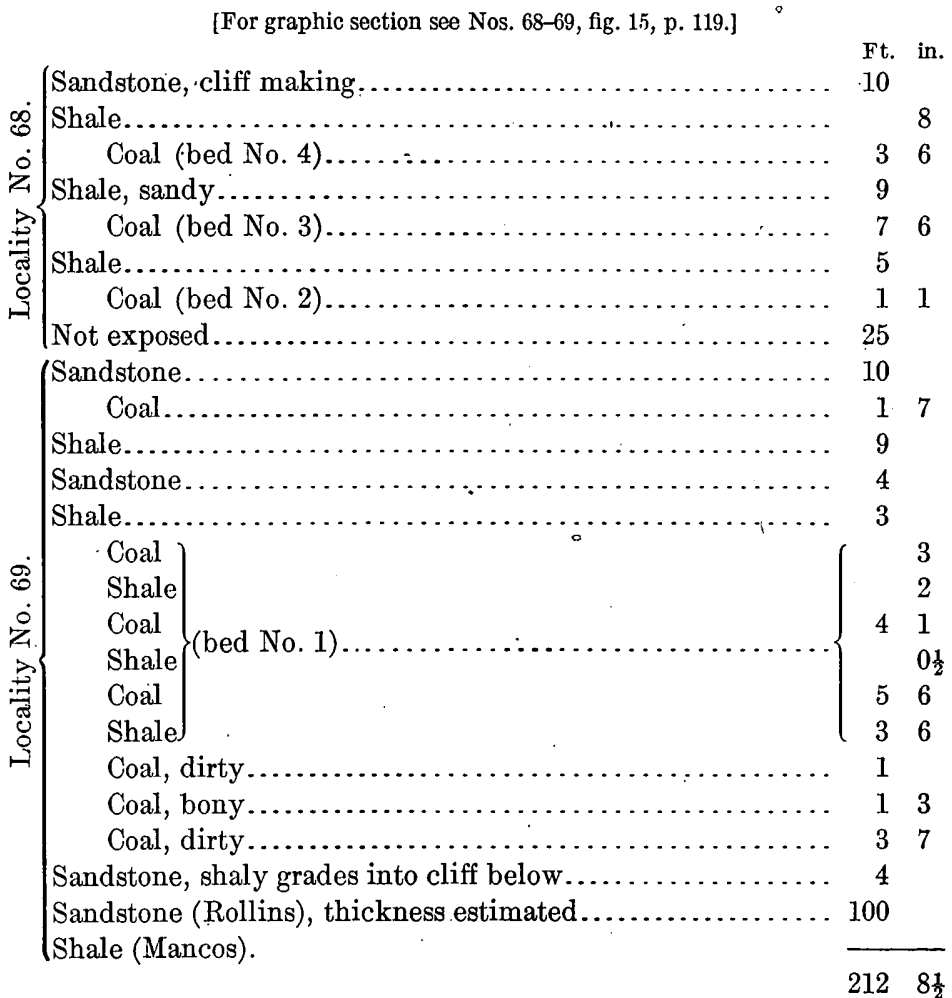

The section of rocks exposed at locality No. 69 includes several hundred feet of Mancos shale, the Rollins sandstone which is here about 100 feet thick, and 51 feet of coal measures including the lowest coal or bed No. 1. Although there are three more or less distinct coal beds at this locality, they are all lower in the section than coal No. 2, which elsewhere is 60 feet above the base of the coal-bearing rocks. For this reason they are regarded as benches of one bed rather than three coal beds.

There can be no doubt that this bed is immediately above the Rollins standstone, but the great thickness of coal is difficult to understand in view of the fact that no coal was found at this horizon in other localities already described where the rocks are well exposed.

At locality No. 68 coal beds Nos. 2, 3, and 4 are well exposed in the north bank of the stream, but the rocks below coal bed No. 2 are partly covered. The coal of the lowest bed found at this place is burned at the outcrop. This burned bed is near the Rollins and is probably coal No. 1. Between it and the overlying coal the rocks 
are covered through an interval of. 25 feet above which are the three coal beds shown in the upper part of the section.

The coal of the lowest bench of bed No. 1 is probably too impure to be of much commercial value. However, the upper two benches contain clean bituminous coal. (See fig. 18.) This coal is relatively soft at the surface, but the fact that it has been exposed to the weather for a long time and has disintegrated to a depth of only a few inches is sufficient proof that the coal would not deteriorate rapidly in commercial handling.

The coals of the higher beds exposed at locality No. 68 are apparently harder than the coal of bed No. 1, probably because they have not been exposed so long to the weather. The exposure is of comparatively recent date and is due to lateral cutting of the stream. The coals are of the hard tough variety found throughout the Coal Creek district in the lower part of the coal measures.

No exposures of coal were found between Wadsworth Canyon and the base of Mount Gunnison. The dip of the rocks indicates that the beds probably outcrop in some parts of this area, but the surface is so covered with brush and with slide rock from the slopes of Mount Gunnison that it was found impracticable to trace the outcrops. Also no coal was found in the area between Wadsworth Canyon and Coal Creek canyon. Probably all the coal beds are present in this area, except perhaps coal No. 8, which occurs above the intrusive sheet of igneous rock and has been partly or wholly eroded away. The presence of the lower beds in the mesa between these two canyons is indicated by their occurrence in Wadsworth Canyon at locality No: 68 and in Coal Creek canyon at the localities next described.

Locality No. 70.--The first exposure of coal found in Coal Creek canyon above the mouth of Wadsworth Creek is in sec. 9 , T. 15 S., R. $89 \mathrm{~W}$., of the projected land net, in the east wall of the canyon, where there is

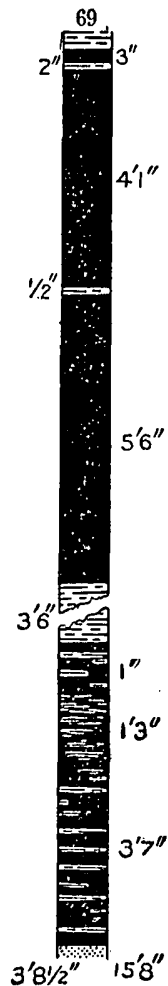

Figure 18.-Section of coal bed No. 1 in Wadsworth Canyon. a bed of coal a few feet below an intrusive sheet of igneous rock. The rocks below the cliff formed by this sheet (see Pl. IX, $A$, p. 113) are so thickly covered with brush and slide rock that no section of the coal-bearing rocks could be measured, except where the surface had been cleared at an old prospect opening in the coal. 
134 COAL OF GRAND MESA AND WEST ELK MOUNTAINS, COLO.

This section is as follows:

Section of coal bed in Coal Creek canyon, sec. 9, T. 15 S., R. 89 W.

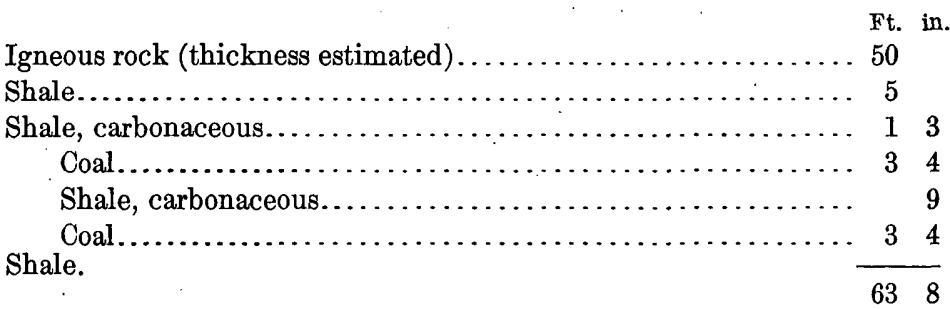

A sample of coal was taken for analysis from a freshly cleared face 40 feet from the mouth of this prospect entry. It includes the two benches of coal the shale parting having been rejected. The results of the analysis are given as No. 9141 of the table of analyses on page 206.

The coal is clean, hard, bright, semibituminous - the so-called anthracite of this district-and has been changed from bituminous by the heat of the igneous rock intruded into the sedimentary beds above the coal.

Apparently this is coal bed No. 6. According to S. L. Mosley, a 6 -foot bed of coal occurs 35 feet below this opening, but the old prospect is now deeply covered with slide rock so that it was impracticable to reopen it. This lower coal bed obviously corresponds to coal No. 5 of other sections.

No evidence was found at this locality of the presence of coal No. 7, and this bed probably was displaced by the intrusion of the igneous rock. The horizon of coal bed No. 8 was followed from the opening in Apache Canyon, locality No. 67, to this place by means of the underlying sandstone, which is persistent, and also by means of coal "blossom," probably derived from this bed, but no place was found where it was practicable to open the coal. None of the lower coal beds have been prospected near locality No. 70, probably because the outcrops of the coal-bearing rocks are so densely covered with slide rock and brush, but the presence of these beds is indicated by isolated masses of crushed coal in the rock slides and by coal "blossom" found in several places.

Locality No. 71.- The next exposure of coal observed in the east wall of the canyon is at locality No. 71, sec. 9 , T. 15 S., R. 89 W., of the projected land net, about a quarter of a mile south of locality No. 70. Coal bed No. 6 was opened at this locality about twenty years ago, and the old entry is still accessible for a distance of about 30 feet. At the mouth of the opening a short section of rocks including the coal bed was measured as follows: 
Section of coal-bearing rocks measured in Coal Creek canyon, sec. 9, T. 15 S., R. 89 W.

[For graphic section see fig. 15, No. 71, p. 119.]

Igneous rock (thickness estimated) . . . . . . . . . . 40

Sandstone and shale, alternating layers............. 35

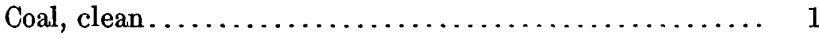

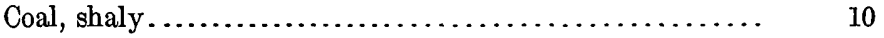

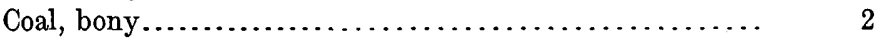

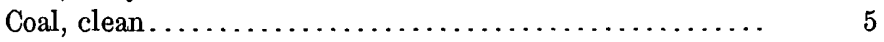

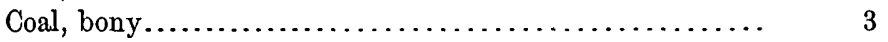

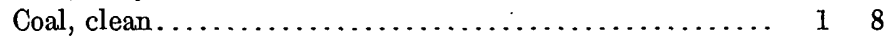

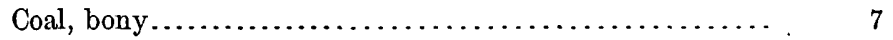

Shale.

Coal, clean ......................... 64

Not exposed................................. 30

Coal (thickness reported) $\ldots \ldots \ldots \ldots \ldots \ldots \ldots \ldots \ldots \ldots \ldots \ldots$

1263

The coal bed is the same as that opened at locality No. 70, and the coal is the same hard variety of semibituminous, locally called anthracite, that was described from the prospect at locality No. 70 . Although the sedimentary beds above this coal are well exposed, coal No. 7 was not found. Coal bed No. 8 occurs here in its proper place above the persistent sandstone and coal "blossom" was found that obviously came from it, but no place was found near this locality that was favorable for opening a prospect pit.

At this locality coal bed No. 5 lies 30 feet below coal No. 6. A prospect now entirely closed was driven in on it several years ago by Mr. John H. Rockefeller, who states that the bed is about 10 feet thick and similar to coal No. 6 described above in that the bed consists of alternating layers of shale, bone, and coal. However, this bed was opened at locality No. 72 farther south and a thickness of 5 feet 8 inches of coal without shale or bony partings was found. The canyon wall is densely wooded near this locality and none of the lower beds was found.

Locality No. 7\%.-A quarter of a mile farther toward the south in the east side of the canyon, at locality No. 72, the second coal bed below the sheet of igneous rock-coal No. 5-was opened, and a short section of the rocks including the coal was measured as follows:

Section of coal-bearing rocks measured in Coal Creek canyon, sec. 9, T. 15 S., R. 89 W.

[For graphic section see fig. 15, No. 72, p. 119.]

Coal ? (bed No. 8).

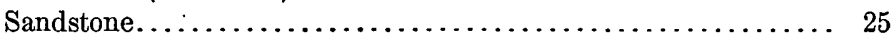

Igneous rock............................. 35

Shale, metamorphosed, and containing No. 6 coal near the base. 30

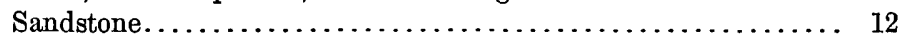

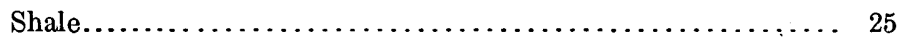

Shale.

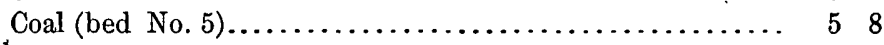


Coal "blossom". indicating the presence of coal No. 8 was found in the disintegrated rock at the top of the section, but no place favorable for making a prospect opening in this coal was found at locality No. 72. No evidence of coal No. 7 was noted, and the sides of the canyon below this bed are so covered with slide rock and brush that none of the lower beds was found.

Mr. J'ohn H. Rockefeller states that a prospect opening was made several years ago in coal No. 6 about a quarter of a mile southeast of locality No. 72 and that the coal bed is similar in character and thickness to coal No. 6, as just described from locality No. 71. The old prospect is now closed and the bed entirely concealed by slide rock from the cliffs above.

Southward from locality No. 72 the base of the coal measures was traced in the field with some degree of certainty, and the horizon of coal No. 8 was followed as far as locality No. 73 , but no place was found favorable for opening any of the coals. The beds outcrop in a steep brush-covered slope at the top of which is a cliff formed by an intrusive sheet of igneous rock. The débris from this rock is much harder than the underlying rocks, and the fragments of the hard material are knit together more or less firmly by the interlocking roots of scrub oak and other brush. In this way a surficial covering is formed that effectually conceals the outcrops of the softer beds.

Locality No. 73.-At locality No. 73, in sec. 16, T. 15 S., R. 89 W., of the projected land net, at an altitude of about 8,800 feet, an old prospect was found and partly reopened. Owing to the quantity of slide rock at the outcrop of the bed, the top of the coal was not seen, but the underlying shale and a thickness of 4 feet 2 inches of clean bituminous coal were found. No outcrops of sedimentary rocks were found near the prospect to give a clue to the stratigraphic position of the coal, but its altitude and its position below the sheet of igneous rock indicate that it may be coal bed No. 6. Coal "blossom" was observed, and a sandstone supposed to be the one that underlies coal No. 8 was traced for about a mile south of this locality, but no coal was found. Isolated exposures indicate that the coalbearing rocks continue for a distance of about 2 miles south of locality No. 73. Little was seen of the rock formations in this part of the district because of the forests that cover the gentler slopes and because of the accumulations of slide rock and glacial débris on the sides of West Elk Mountain.

Locality No. 74.-At locality No. 74, well up on the side of West Elk Peak at the head of Coal.Creek, there is a small area of coal-bearing rocks apparently isolated from the main body. A small exposure of the rocks was found, which contains two coal beds. The lower bed is 1 foot 9 inches thick with shale above and below. The higher one apparently is much thicker and occurs 40 feet higher in the section. 
It was not practicable to open the coal, which was not well exposed. The interval of 40 feet between the beds suggests that they may be coal beds No. 5 and No. 6 , but nothing else was found to indicate their stratigraphic position.

Locality No. 75.-The area between Coal Creek and Robinson Creek is occupied by a mesa consisting of sedimentary rocks that dip toward the north. The surface of the mesa is a dip slope formed by the resistant sandstones that occur at about the horizon of coal bed No. 8 . No coal was found in this mesa at the horizon of No. 8 bed south and east of the localities described along Coal Creek, but this coal bed undoubtedly occurs in the higher parts of the mesa, although it is eroded in the neighborhood of the intermittent streams that have cut more or less deeply into the rocks.

It was deemed impracticable to locate and open the coals in the brush-covered slopes of this mesa. Only one of the lower beds was found, and an opening was made on it in the south wall of Robinson Canyon, at locality No. 75. The coal is crushed and displaced by the surface creep of the rocks, and no undisturbed coal was found. The quantity of crushed coal indicates that the bed may be 4 or 5 feet thick. Nothing was found to fix the position of the bed in the section except that it is near the middle of the coal-bearing formation.

Little more is known of the occurrence of coal north and east of Robinson Creek than is known of it in the mesa just described. The sedimentary rocks dip toward the north and outcrop under the igneous rock of the Cliff, which is about 1,000 feet thick near the mouth of Robinson Creek (see Pl. IX, $B$, p. 113) but apparently thins toward the southeast. The fragmental débris from this cliff covers the outcrop of the underlying beds in many places. The sandstone layers in the upper part of the coal-bearing zone become more and more prominent toward the east and the Rollins sandstone, which elsewhere makes a prominent cliff, does not form a shelf in the brush-covered slopes in Robinson Canyon. The general result of this combination of circumstances is the formation in the coal-bearing zone of slopes covered with rock débris and brush in which few exposures of undisturbed rock are to be found. (See Pl. VIII, $B$, p. 112.)

Locality No. 76.-In sec. 25, T. 14 S., R. 89 W., of the projected land net, at locality No. 76 , an old coal prospect was found and reopened in a bed 55 feet above a prominent sandstone cliff, which here strikes $\mathrm{N} .70^{\circ} \mathrm{E}$. and dips $15^{\circ} \mathrm{N}$. The coal bed is 3 feet thick with shale roof and shale floor, but the coal is crushed by the surface creep of the rocks, and the bed where not affected by this movement is probably more than 3 feet thick. No other coal beds were found, but coal "blossom" found on the surface indicates that at least one higher bed of coal is present below the sandstone cliff that underlies coal bed No. 8 , which was identified at this point. This relation seems to 
show that the 3-foot bed may be coal No. 6 of the other sections described. No indication of the presence of any other coal beds was found at this locality.

Locality No.77.-Coal "blossom" was found at the horizon of No. 8 coal bed in several places east of locality No. 76 , but no place was found where it was practicable to open the coal. However, in sec. 31, T. 14 S., R. $88 \mathrm{~W}$., of the projected land net, on the north fork of Robinson Creek at an altitude of about 8,300 feet, a coal bed having the following cross section was found at locality No. 77 , in the bed of the stream.

Section of coal bed on North Fork of Robinson Creek, sec. 31, T. 14 S., R. 88 W.

Shale.

Ft. in.

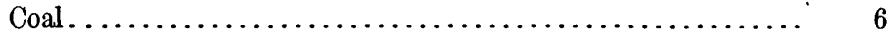

Shale................................... 10

Shale.

Coal. ....................................... 32

46

This coal is above a sandstone cliff and it is thought to be coal bed No. 8 , although neither the outcrop of the coal nor that of the underlying sandstone could be followed in the wooded slopes of the canyon. The full thickness of the bed was not seen in this prospect. The coal is crushed and is in a rock mass that is probably a part of an old landslide. The rocks near the coal strike N. $40^{\circ}$ E. and dip $45^{\circ}$ S., and the general strike of the undisturbed rocks near this locality is N. $60^{\circ}$ W. and the $\operatorname{dip} 15^{\circ} \mathrm{N}$. No other beds of coal were found in this canyon, but S. L. Mosley states that he has seen another 4 -foot bed of coal in the bottom of the canyon. Although careful search was made, this coal was not found, and it probably was covered with stream débris at the time of investigation.

Locality No.78.-Coal-bearing rocks occur in the area between the forks of Robinson Creek and extend eastward under the West Elk breccia. S. L. Mosley and John H. Rockefeller, who are probably more familiar with this area than any other men, state that coal has. been seen there in a few places, but at only one locality (No. 78) was any found during the investigation described in this paper. Because of the forested condition of this area, the outlines of the coal-bearing formation could not be determined with any degree of accuracy without the aid either of a previously constructed map or an expenditure of much more time and money than was available at the time of investigation.

The occurrence of coal east of localities Nos. 77 and 78. between the Coal Creek district and the Mount Carbon field and between this district and the-Floresta field, is uncertain. Toward the east the coal beds apparently descend under Storm Ridge, as indicated in section E-D of Plate I (in pocket), but they are deeply buried under younger sedimentary rocks, igneous intrusives, and thick masses of 
the West Elk breccia. (See Pl. XII, B, p. 146.) Between the Coal Creek district and the Floresta field the coal beds lie beneath a considerable thickness of the Wasatch formation and the full thickness of the unproductive part of the Mesaverde, in which have been intruded a mass of igneous rock, and above all rests the laccolithic mass of Mount Lombard and Mount Beckwith. The relations of the coal to the superincumbent rocks in this region are shown by the structure sections on Plate I.

\section{FLORESTA FIELD.}

GENERAL STATEMENT.

Seven miles east of the easternmost locality at which the coal outcrops in the Coal Creek district, the bedš emerge from beneath their thick cover of younger rocks and outcrop on the north flank of the Anthracite Range, where the rocks have been sharply upturned and the coal exposed by erosion. The sedimentary rocks dip northward $18^{\circ}$ to $24^{\circ}$, and the coal beds extend to depths of 3,000 feet or more beneath the surface. In most places in this field the surface is densely wooded, and only small isolated exposures of rock were found. In the canyon at Floresta near the Ruby-Anthracite mine, the top of the Mancos shale, the Rollins sandstone member of the Mesaverde, and the base of the coal measures of the Mesaverde are perfectly exposed and gave the measurements appearing in the following section. (These formations are described in Geologic Folio No. 9 as Pierre, Fox Hills, and Laramie.) The rocks near the top of the Mesaverde are exposed in a railway cut north of Floresta, and the upper part of the section was measured in this cut. The intermediate rocks are only partly exposed, and their thickness was estimated at 500 feet.

\section{Section of rocks measured at Floresta, Colo.}

Igneous intrusive rocks, porphyrite (thickness estimated).... 200

Sandstone, with fossil palm leaves................... $\quad 15$

Shale, with thin layers of sandstone................... $\quad 12$

Shale, carbonaceous, with a coal bed 2 inches thick.......... 3

Sandstone, massive, with irregular base.................. $\quad 40$

Shale and sandstone in alternating irregular layers.......... $\quad 35$

Sandstone, cliff making.............................. $\quad 20$

Not exposed (thickness estimated).................. 500

Sandstone, cliff making (thickness estimated)........... $\quad 30$

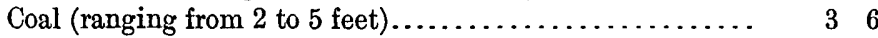

Shale, dark colored, with irregular layers of shaly sandstone... 115

Base of coal measures.

Sandstone (Rollins), massive..........................

Shale and sandstone in thin alternating layers (top of Mancos), thickness variable.

Intrusive igneous rock. 
Only one coal bed of any considerable thickness has been found in this field. A seam of coal 2 inches thick was found near the top of the section, and Eldridge reports coal 4 to 6 inches thick 100 feet above the main bed. The failure to find other.coal beds in the lower

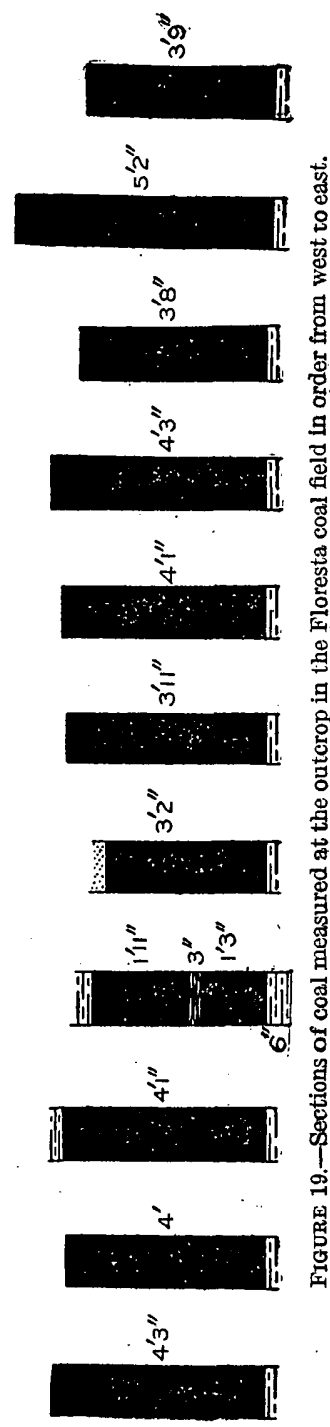
part of the coal-bearing formation is not due to surface covering, as is the case in other districts where coal beds that are known to exist do not appear at the surface. The rocks below the coal are well exposed at Floresta, and the absence of coal at the surface is sufficient evidence that none occurs below the main coal bed. A thickness of about 600 feet of rocks overlying the main coal has been penetrated by the diamond drill without finding coal above the main bed. Records of two drill holes made in this field show only one bed of coal, and in a third hole no coal was found, as shown in figure 20.

Fossil plants occur in the roof shale of the main coal bed, from which it is inferred that this bed should be referred to the Paonia member of the Mesaverde formation. No fossils were obtained from the beds in the lower part of the section, and no evidence was found to determine whether the Bowie member is present here or not. The absence of coal from the lower 115 feet of the section and the association of fossil plants with the lowest coal bed suggest that the Bowie may be absent from the Floresta field, either because it was never deposited there or because it was eroded away before the deposition of the Paonia, as it probably was in the Rollins district of the Grand Mesa field previously described. However this may be, it is certain that there are no coal beds in the Floresta field that correspond in stratigraphic position with the Bowie coal beds of the Grand Mesa field, seven of which occur in the Coal Creek district only a few miles farther west.

RUBY-ANTHRACITE MINE.

The coal of the Floresta field is mined at Floresta, a small town situated on one of the tributaries of Anthracite Creek at the end of a branch railway which connects with one of the main lines of the Denver \& Rio Grande system at Gunnison. ' It lies on the north slope 


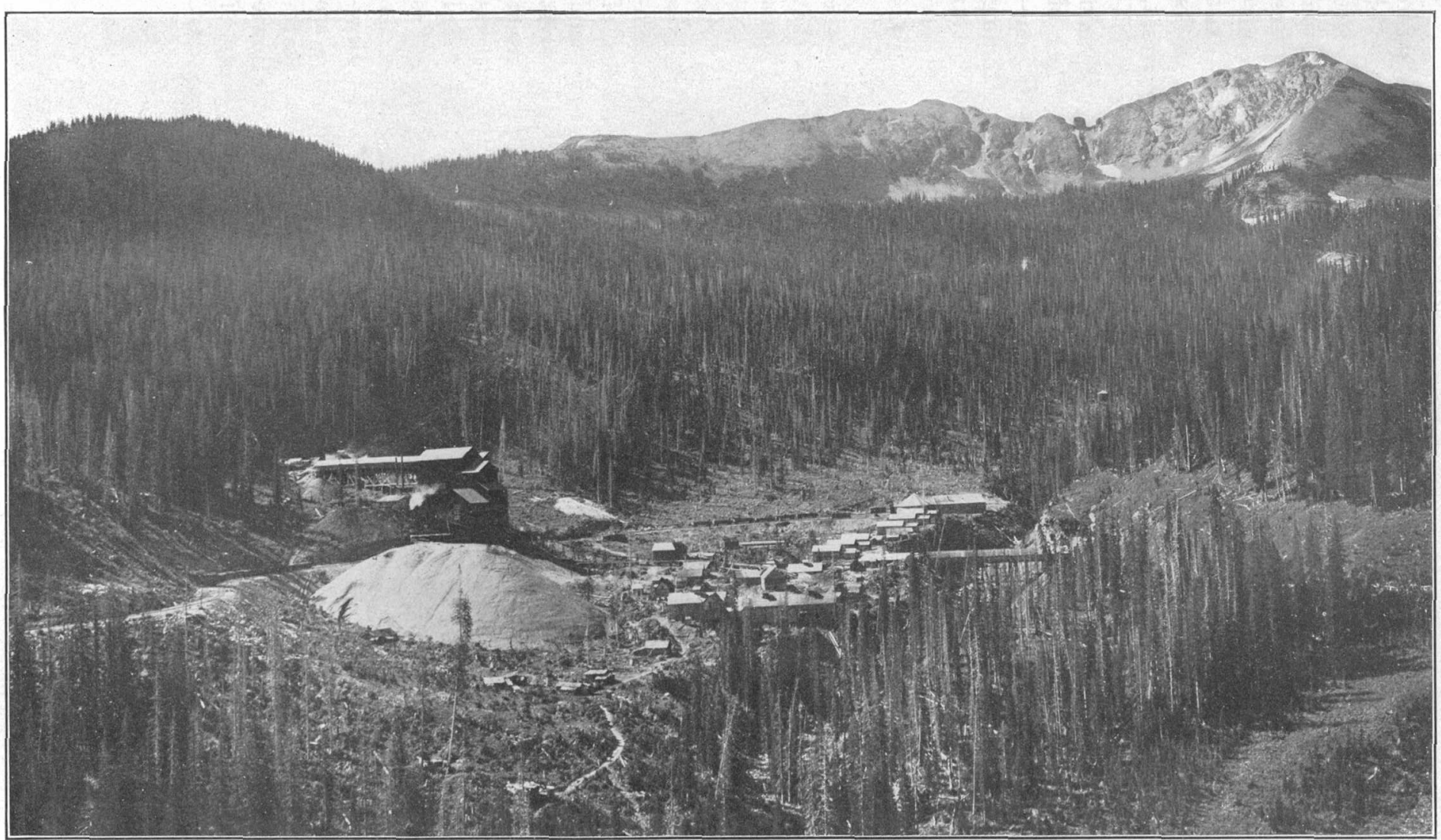

THE RUBÝ-ANTHRACITE MINE AT FLORESTA, COLO

The forest-covered slopes are characteristic of the Floresta field. 
of Anthracite Range in sec. 16, T. 14 S., R. 88 W., at an altitude of about 10,000 feet. The entrance to the mine is in the west wall of the canyon, and mining operations were being carried on at the time of investigation in the western part of sec. 16 and the eastern half of sec. 17. A small area east of the canyon was worked formerly but these openings are temporarily abandoned.

The coal has been opened in prospect entries along the outcrop for a distance of about 3 miles, and measurements of the bed'were obtained

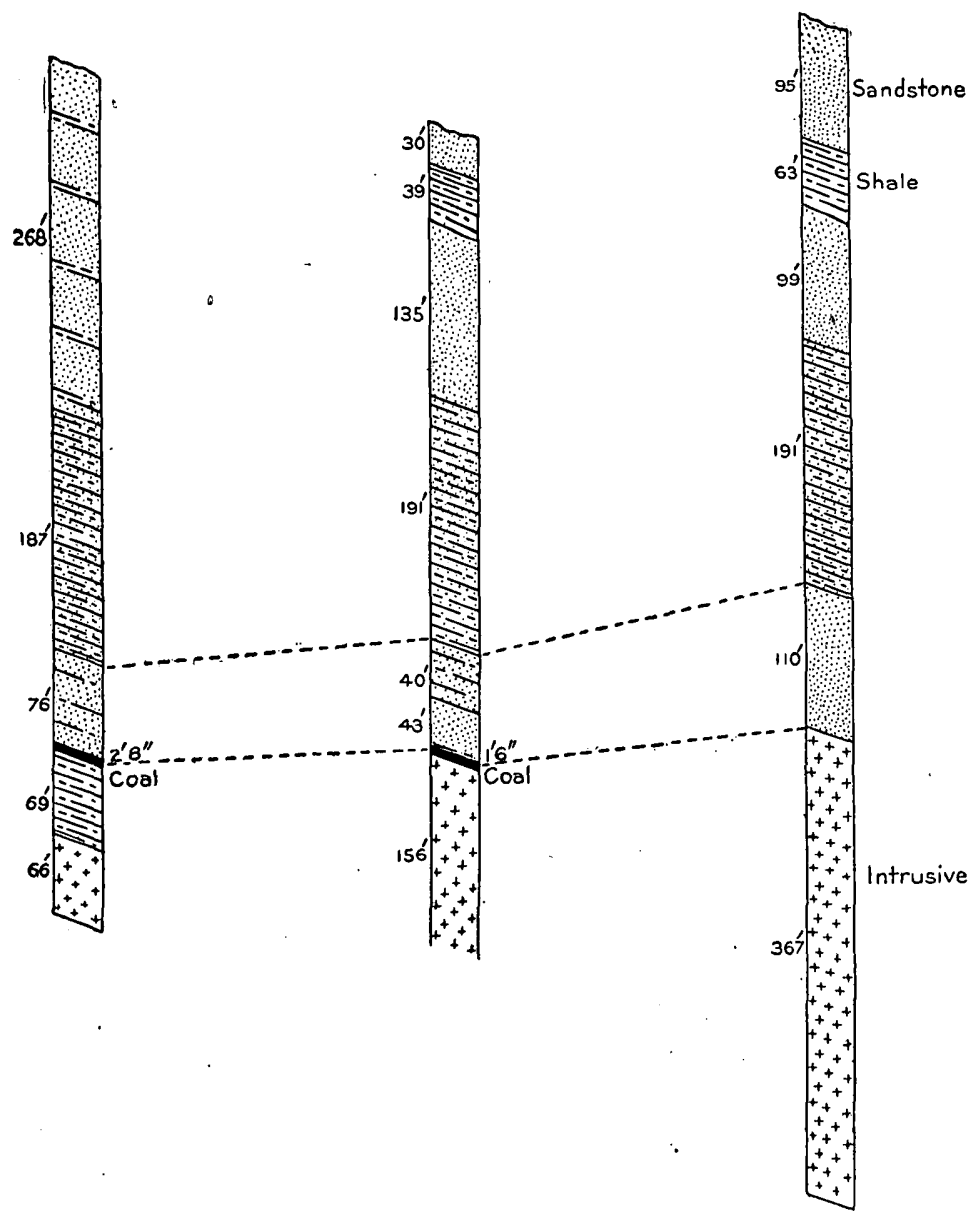

FiguRE 20.-Records of drill prospects in the Floresta coal field.

at eleven of these prospects (see fig. 19) showing an average of nearly 4 feet of coal. Naturally the prospect openings were made where there was the best showing of coal at the surface and the average thickness shown is about 1 foot 7 inches greater than the average of 20 measurements of thickness made in the mine workings west of the canyon. 
Throughout more than half of the area of the mine, the coal is overlain by a massive sandstone, but in some places a shale, which has an observed maximum thickness of 15 feet, intervenes between this and the coal. This shale is known to thin from this maximum and disappear within a horizontal distance of 250 feet. Where it occurs it is made to serve as the roof of the mine, elsewhere the roof is sandstone. This sandstone is strong and not only forms a safe protection for the workings but is doubtless one of the causes of the remarkable regularity of the bed in the developed area west of the canyon. In this developed area the rocks apparently constitute a block which, except for minor internal movement to be described later, moved as a more or less rigid mass, thus contrasting rather strongly with other areas in the Floresta field, where the rocks are broken and faulted.

The shale is not so strong as the sandstone but when properly timbered makes a satisfactory roof. It is not jointed and the lamination is more or less destroyed by crushing or shearing. In some places it falls in plates and in others as "pots" or as slickensided masses of irregular shape. It does not slack or crumble readily in the mine, and although some crossbars are used the timbering is done mainly with props and caps. The roof shale parts readily from the coal, and there are few irregularities in the roof. No pyrite masses or horsebacks have been found, but some rolls occur. No gas has been detected in the roof shale.

The coal is a hard, black, anthracite, with vitreous luster, conchoidal fracture, and a fine banded texture. In some places it has contorted laminæ and slickensided faces. In other places the banding has been destroyed by the shearing movements to which the coal has been subjected. Before the disturbances that caused the upheaval of the Anthracite Range, this coal probably did not differ from the soft bituminous coal of the neighboring fields that has not been affected by rock movements, but during the upheaval of the mountains the soft coal apparently acted as a stiffly viscous mass, thinning in some places and thickening in others.

The coal has low percentages of moisture and ash and relatively high heating value. It burns readily and is prized as a domestic fuel. For this use it is crushed in a breaker (see Pl. XI, p. 140) and screened into lump, egg, stove, nut, and pea sizes, the amount of each size produced being about 15 per cent, which leaves 25 per cent that is classed as slack. The coal bed ranges in thickness from a foot to about 5 feet. Twenty measurements in the mine gave an average thickness of 2 feet 5 inches. There are no persistent partings and little bedded impurity. The coal is uniform in character throughout the developed area. Jointed structure is practically wanting probably because of the rock movements just described. The floor of the mine consists of soft shale, which heaves considerably in some places, though not enough to interfere seriously with mining operations. 
A sample of the coal wàs taken for analysis from a working face where the bed is 4 feet 5 inches thick. The results of the analysis are given as No. 8120 of the table of analyses on page 206 .

No folds have been encountered in the developed area, but the beds are warped to some extent, the dip varying in the mine from $18^{\circ}$ to $25^{\circ}$. Several small faults and slips have been encountered in the workings, and there are several dikes of igneous rock in and about the mine. These have not greatly affected the coal in the developed area west of the canyon, but on the east side the rock movements have broken and otherwise disturbed the coal to such an extent that its value is greatly diminished.

The entrance to the present workings of the mine is by drift entries run in on the coal along the strike at five different levels, and these entries are connected by underground gravity inclines constructed on the slope of the coal bed and operated with rope and drum. The general plan of the workings is by the single entry room-and-pillar system, except at the lowest two levels, which are driven with double entries. From the main entries driven along the strike the rooms are turned up the rise and extended to the next main entry above. The coal descends through chutes from the rooms to the cars in the main entries below.

In the worked-out areas the pillars are drawn by the retreating method, and the settling of the roof is gradual, owing to theresistant sandstone above the coal. Although little gas has been found in this mine, the general policy of the coal company requires the use of safety lamps, and no other light is allowed in the mine. Ventilation is produced by a 10-foot Sturdivant propulsion fan, and the air is distributed by the splitting method. The air currents are directed within the mine mainly by means of brattices. The mine is relatively dry, but the workings are laid out in such a way that they drain without the aid of pumps.

The coal is drilled by hand and shot from the solid. The loaded mine cars are hauled to the inclines by mules, lowered by rope and drum over the inclines, and hauled to the mouth of the mine where they are hoisted by rope to the breaker over an outside incline. The cars each have a capacity of 2,600 pounds; 25 wooden cars and 40 steel cars are used.

The breaker is situated above the entrance to the mine, as shown in Plate XI, page 140. It has a capacity of about 500 tons of coal per day and is provided with scales for weighing in the pit cars, a Mitchell tipple, a 30 -foot bar-screen, and two revolving screens. The coal is picked by hand in the breaker and is loaded directly in the railway cars for'shipment. A storage capacity is provided for about 700 tons of coal. Some of the coal is used on railway locomotives, but it is used chiefly as a domestic fuel. 


\section{MOUNT CARBON FIELD.}

(Nos. 79-112.)

\section{GENERAL STATEMENT.}

The Mount Carbon coal field lies at the southeastern extremity of the Uinta Basin region and is separated from the Coal Creek district on the west by spurs of the West Elk Mountains, from the Floresta field on the northwest by the Anthracite Range, and from the Crested Butte field on the north by the laccolithic masses of Mount Carbon, Mount Axtell, and Mount Wheatstone. The field drains through Ohio and Carbon creeks into Gunnison River and a branch railway has been extended into it from the town of Gunnison, reaching the mines at Mount Carbon and Kubler.

The coal beds of this field are readily accessible from the valleys. In the localities where mines are being operated, the coal outcrops near the level of the valley floors. A considerable area of coal land near Mount Carbon and Kubler is favorably situated for mining. Because of the northward dip of the rocks in the western part of the field, the outcrop of the coal rises toward the south from Mount Carbon, but at all places along the outcrop west of Ohio Creek the slopes are moderate, and approach to the coal is relatively easy. East of Carbon Creek the rocks have a general westerly dip, and the outcrop rises toward the east to an altitude of about 11,000 feet, or about 2,000 feet above the railway at Kubler, 4 miles west. The coal beds in this part of the field are only thinly covered with younger rocks, and the approach to the coal is not made difficult by rugged topography.

The sedimentary formations in the Mount Carbon field do not differ notably from those described in the Grand Mesa field on the west. The Mancos shale is the oldest formation exposed and occupies the surface in the southern and eastern parts of the field. This shale is overlain by the Rollins sandstone, the lowest member of the Mesaverde formation. The Bowie shale member of the Mesaverde is present in the western part of the field but not in the eastern part, as is indicated by the presence of marine and brackish water invertebrates in rocks lying above the lowest coal bed south of Mount Carbon. Neither the lowest coal bed nor any brackish water shells were found at the eastern extremity of the field. The main body of coal-bearing rocks is referred to the Paonia member of the Mesaverde formation on the evidence of its fossils, which consist of plants of the same species as those found in the Paonia member in the Grand Mesa field. The coal beds of the Mount Carbon field that are known to be of commercial importance occur in this member. Above the Paonia member lie the non coal-bearing rocks, which Eldridge called "unproductive measures," and which are described in this bulletin as the upper or 
undifferentiated part of the Mesaverde formation. These rocks are not well exposed in the Mount Carbon field and little was learned concerning them. The Ohio Creek conglomerate lies unconformably on the Mesaverde and except for the Quaternary material of the valleys is the youngest sedimentary formation in the field.

The coal-bearing rocks disappear toward the west under the West Elk breccia, which forms the north spurs of West Elk Peak, and reappear in the Coal Creek district, as previously described. The distance between the outcrops of the Coal Creek district and those of the Mount Carbon field is about 12 miles, but how far the coal beds continue beneath the cover is not known. In the Grand Mesa field there is a plainly marked unconformity that separates the Bowie member from the Paonia member of the Mesaverde. It is not definitely known how far this unconformity can be traced toward the east, but the apparent absence of the Bowie member from the eastern part of the Mount Carbon field indicates either that it never was deposited here or that it was removed by erosion before the deposition of the Paonia member. In either case its absence is a matter of great economic importance, for only one of the 9 coal beds that occur in the Bowie in the Somerset district is found in the Mount Carbon field and this one only in the western part of the field.

Apparently all the coal-bearing rocks were removed by erosion from the southern part of the area intervening between the Coal Creek district and the Mount Carbon field before the formation of the West Elk breccia. This breccia apparently extends across the eroded edges of thercoal beds and lies upon the Mancos shale in the southern part . of this area. A like relation obtains in Mount Wilkinson, where all rocks younger than the Mancos shale were removed by erosion in some places previous to the outpouring of the basalt that forms the protecting cap of this mountain.

On the north the continuity of the coal-bearing rocks is interrupted by the Anthracite Range, Mount Carbon, Mount Wheatstone, and Mount Axtell. The Anthracite Range consists of a mass of igneous rock that was thrust up through the coal-bearing formation displacing all coal beds. The Mount Carbon laccolith (see Pl. XII, A, p. 146) was intruded into the sedimentary rocks at about the horizon of the coal beds. West of this mountain the coal was upturned, but east of it coal beds underlie the igneous rock in at least one locality (No. 96). It is quite impossible to determine without extensive and costly prospecting to what extent the coal beds underlie Mount Carbon, but it is probable that any coal extending under the laccolith is of little commercial value, for it must have been greatly disturbed during the intrusion of the igneous rock. Little more is known of the relation of the coal beds to the Mount Wheatstone laccolith than is known of their relations to Mount Carbon. At the $40642^{\circ}-$ Bull. $510-12-10$ 
the eastern end of Mount Carbon field, at locality No. 110 of the accompanying map, coal beds lie underneath the igneous rock of Mount Wheatstone, but they are cut off by it a short distance farther north. Farther west the coal-bearing rocks apparently underlie the laccolith, but north of Mount Wheatstone they are upturned on its flanks. As in the case of Mount Carbon, it seems probable that the area occupied by the igneous rock of Mount Wheatstone can not be regarded as valuable for coal mining. The igneous rock of Mount Axtell was intruded at a horizon considerably above the coal, and there is good reason for believing that the coal beds extend continuously under the laccolithic mass, thus connecting the Mount Carbon field with the Crested Butte field in the same way that the former field is probably connected on the west with the Coal Creek district, as previously described.

The coal has been exploited in the Mount Carbon field only in the places where it is most easily accessible, and there are large areas of coal land presumably containing as valuable deposits as any found in the developed areas, in which little prospecting has been done. The mines and prospects so far as they are known are described in detail below. There are more place names that can be used in describing localities in this field than there are in the Coal Creek district, but there are many prospect openings that can be located on the map only by some artificial means, and locality numbers are employed for this purpose as they were in the districts farther west.

The intrusion of the igneous rock, besides displacing thecoal beds in the vicinity of the laccoliths, had the effect of throwing the coal beds and their associated rocks into undulations producing many small faults that are annoying to the coal miners and render the results of prospecting unreliable in some places. The throw of most of the faults in the Mount Carbon field is slight, and it is only in the best exposed and best developed parts of the field-between Ohio Creek and Carbon Creek (see fig. 22, p. 153) - that the faults can be located with any degree of accuracy. No doubt the rocks in other parts of the field are faulted, but it remains for future investigation and development to indicate their trend and their effect on the coal beds.

Two coal beds of economic importance occur in the Mount Carbon field and there are indications in some places of a third. The lowest, or coal bed No. 1, occurs just above the basal or Rollins sandstone in sediments of marine and brackish-water origin. At the southwest extremity of the field this bed has a maximum thickness of 11 feet at locality No. 84 (see fig. 21) and thins toward the northeast. In the vicinity of Mount Carbon it is 2 to 3 feet thick (see fig. 24, p. 156), and at locality No. 102 it contains only $7 \frac{1}{2}$ inches of coal. Coal was not found at the horizon of bed No. 1 east of locality No. 106, and it 


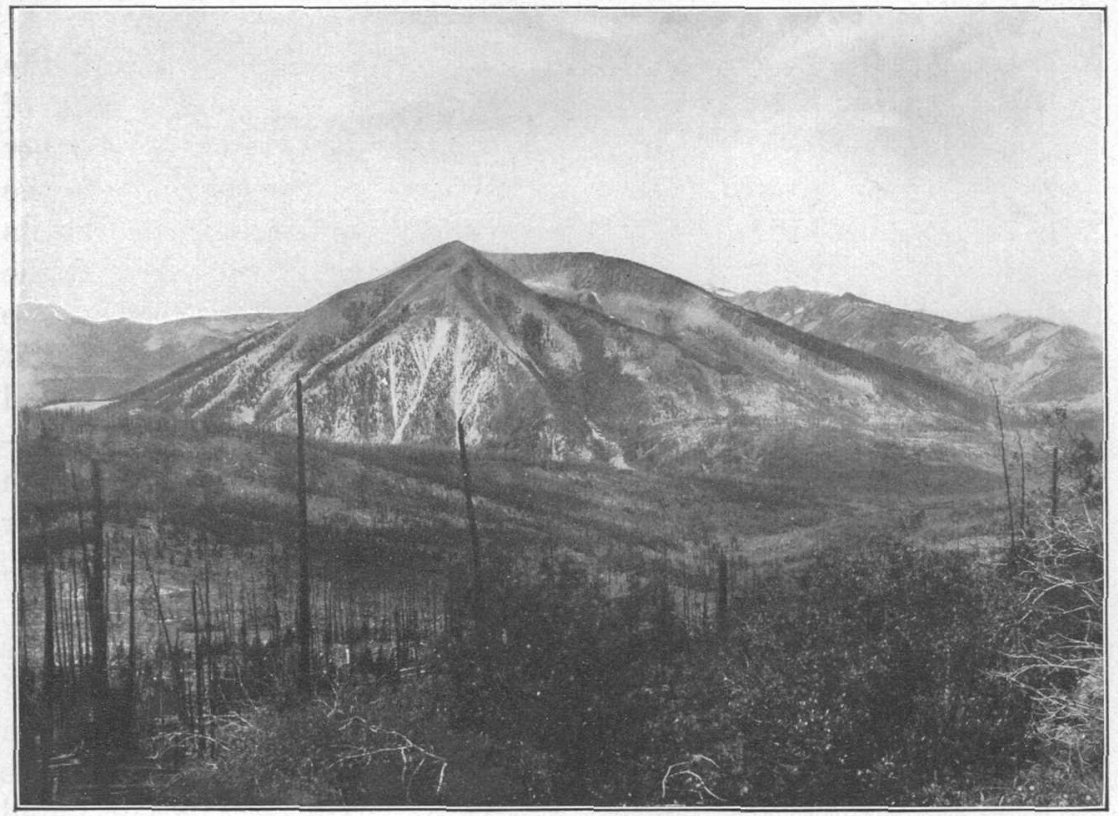

A. MOUNT CARBON, A LACCOLITH OF PORPHYRY INTRUDED INTO THE COAL MEASURES.

Porphyry was intruded at about the horizon of the coal and displaced some or all of the coal beds. The north slope at the right is probably the original upper surface of the intruded mass. At the extreme right the sedimentary rocks are upturned on the flanks of the laccolith.

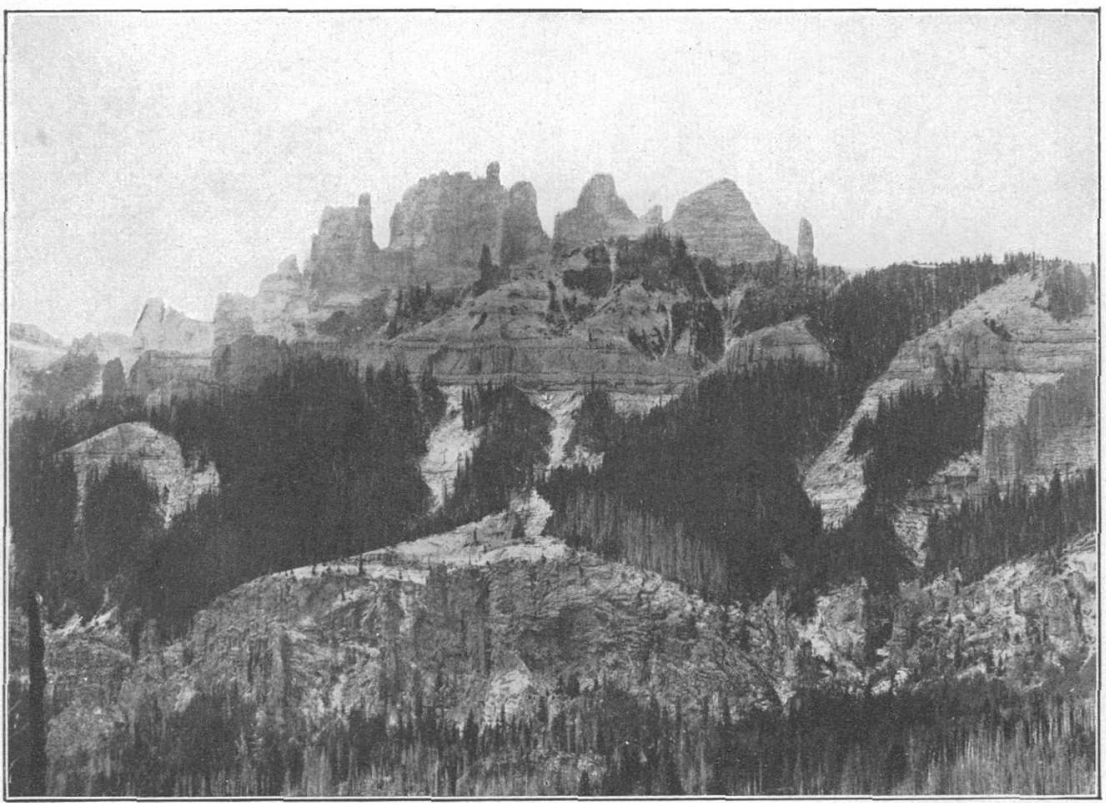

B. THE CASTLE, A CONSPICUOUS PROMONTORY WEST OF MOUNT CARBON.

Showing the bedded character of the West Elk breccia, which overlies the coal beds between Mount Carbon field and Coal Creek district. 
is the writer's belief that this bed together with the 85 feet of sedimentary rocks between it and coal bed No. 2 have disappeared between this locality and locality No. 110, where coal bed No. 2 rests on the Rollins sandstone.

In the vicinity of Kubler, coal No. 2 lies about 85 feet above the basal sandstone and is the one in which nearly all of the important openings in the Mount Carbon field have been made. Apparently the bed is persistent throughout the field, and wherever it was opened it was found to contain coal of relatively uniform character and thickness. The bed is associated with fossil plants of the same species as those contained in the Paonia shale in the Grand Mesa field, and it is significant that the coal beds, which, in the Grand Mesa field, correspond to this one in stratigraphic position-Bed No. 8 in the Coal

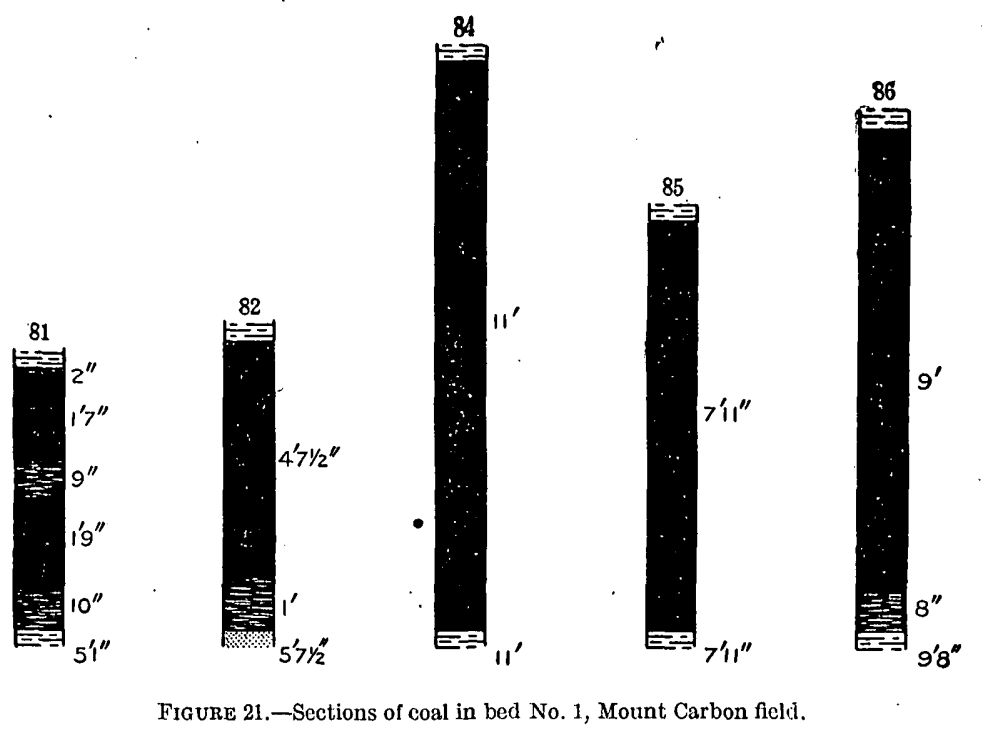

Creek district and the Paonia coals farther west-are notably more uniform in character and thickness over wide areas than are the lower or Bowie coal beds.

Coal No. 3 of the Mount Carbon field has not been observed in a sufficient number of places to warrant the assumption that it is continuous throughout the field. Apparently it is not of great economic importance. In the few places where it has been observed, it is not at a uniform distance above coal bed No. 2-a fact more nearly in accord with the assumption that there is a series of lenticular bodies of coal at about the same horizon than with the existence of a continuous bed. All information obtained concerning it is given in the following pages. 


\section{DESCRIPTIONS OF LOCALITIES.}

Locality No. 79.-At locality No. 79, formerly known as Mount Carbon post office, the coal-bearing rocks are steeply upturned on the west flank of Mount Carbon in sec. 25, T. 14 S., R. 87 W., of the projected land net. The average dip is about $45^{\circ}$. The exposures of the coal-bearing rocks are very poor, but the number of coal beds as well as the thickness and character of the coal are known from an old tunnel long since abandoned (see Folio 9), that was driven into the mountain side at the level of Ohio Creek. The lowest bed of coal is 1 foot thick and is underlain by 200 feet of metamorphosed shale. Higher in the section and separated from the lowest bed by 250 feet of sedimentary rocks is a coal bed 3 feet 6 inches thick, and 45 feet higher there is a third coal 1 foot 6 inches thick. These beds have been designated as coals No. 1, No. 2, and No. 3 in order from base upward. The coal is described as being in part coking bituminous and in part semianthracite. Old coke ovens are still to be seen on Ohio Creek near the mouth of the old tunnel. The coking coal is in themiddle bed, or coal No. 2, and although 250 feet above coal bed No. 1 is possibly the same bed as that exploited at the town of Mount Carbon at the present time, which is about 85 feet above coal bed No. 1 . The greater thickness between the beds at locality No. 79 may be due to a local thickening of the strata caused by the intrusion of the Mount Carbon laccolith. On the other hand, coal No. 2 of thislocality may be a higher bed of which little is known. Where the rocks are so faulted and otherwise disturbed as they are at this locality, any correlation of the beds must remain provisional until more definite information is obtained.

The quality of the coal at this locality is shown by the following proximate analyses reported in Folio 9. ${ }^{1}$ The first analysis represents bed No. 1, and the second analysis bed No. 2, which is the coking bituminous coal of this locality.

Analyses of coal from abandoned mine west of Mount Carbon.

\begin{tabular}{|c|c|c|}
\hline . & Bed No. 1. & Bed No. 2. \\
\hline 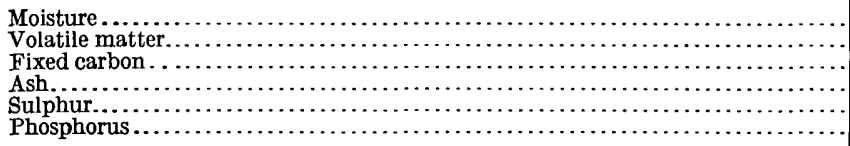 & $\begin{array}{r}0.81 \\
9.96 \\
82.33 \\
6.90 \\
1.06 \\
\end{array}$ & $\begin{array}{r}1.15 \\
26.43 \\
68.31 \\
4.10 \\
.60 \\
.5\end{array}$ \\
\hline
\end{tabular}

The difference between the characters of these coals is attributed by Eldridge to their relative proximity to the eruptive rock of Mount Carbon; coal No. 1, being nearer to the igneous rocks than coal No. 2,

1 See also Clarke, F. W., A report of work done in the division of chemistry and physics, mainly during the fiscal year 1888-89: Bull, U. S. Geol. Survey No. 64, 1890, 
is metamorphosed to a greater extent. Doubt is cast on this interpretation by the character of the coal at locality No. 96, where coal bed No. 2 is much nearer to the eruptive rock than is coal No. 1 atlocality No. 79 and yet is not greatly metamorphosed. From its geologic relations at the La Plant mine farther south, locality No. 81, the lowest or coal bed No. 1 is known to be in the Bowie or marine and brackish-water member of the Mesaverde, but coal No. 2 is in the Paonia or fresh-water member. At localities where the coals have not been metamorphosed the lower or Bowie coals are harder and in other ways of better grade than the upper or Paonia coals. For these reasons it is regarded as possible that the differences shown by the analyses just quoted may be due in some measure to original differences in the quality of the coals rather than to metamorphism from igneous intrusion.

Locality No. 80.--No coal was found south of locality No. 79 for a distance of more than 3 miles. At locality No. 80 , in sec. 12 , T. 15 S., R. $87 \mathrm{~W}$., of the projected land net, a shaft has been sunk recently and 5 feet 3 inches of coal dipping northwest was penetrated at a depth of 30 feet. Its thickness and position indicate that it is probably bed No. 2, or the same coal as that opened in the Alpine mine at the town of Mount Carbon.

Locality No. 81.-The next locality toward the south at which coal was observed on the west side of Ohio Creek is at the La Plant mine, locality No. 81. A shaft has been sunk here through the coal bed and 20 feet into an underlying sandstone. From the shaft a drift had been extended toward the west 400 feet along the coal bed at the time of investigation. The bed as seen in this 400 feet shows considerable variation in thickness and in the amount of bone contained in the coal. At the end of this drift the following section of the coal bed was measured, and a sample of coal was taken for analysis. The bone does not separate readily from the coal. The sample includes the two benches of clean coal shown in the following section, the intervening 9 inches of bone, and 1 inch of the upper bone. The results of the analysis are given as No. 8619 of the table of analyses on page 206 .

Section of coal bed in the La Plant mine, near Mount Carbon, Colo., sec. 18, T. 15 S., R. $86 \mathrm{~W}$.

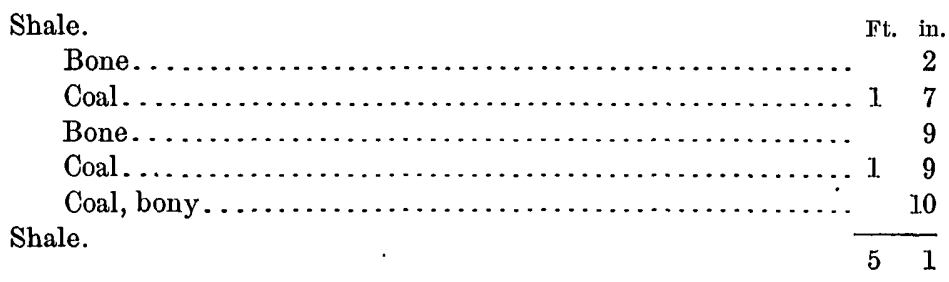


The sandstone below the coal is massive, white, and has the general appearance of the basal or Rollins sandstone. In rocks above the coal marine and brackish-water shells occur, and Anomia sp. and Inoceramus barabini were collected from them at this locality. From these facts it is inferred that the coal bed is the lowest in this field and that it belongs in the Bowie member of the Mesaverde formation. It therefore corresponds in position to the beds containing the highest grade coals in the Grand Mesa field on the west and may reasonably be expected to contain coal of superior quality in the Mount Carbon field.

Many attempts have been made to locate coal beds west of Ohio Creek in the vicinity of the La Plant mine, but no satisfactory surface indications have been found. An old prospect a quarter of a mile north of the La Plant mine, now inaccessible, is said to have shown 6 feet of coal. This is probably coal No. $\overline{2}$. Several drill prospects have been put down near locality No. 81, but various results are reported. It is safe to infer that unfavorable conditions were found, for no development followed this prospecting.

Locality No. 82.-A hole sunk at locality No. 82 gives the most satisfactory section of rocks available in this vicinity. It is the only drill record preserved. The record is as follows:

Record of drill prospect at locality No. 82, southwest of Mount Carbon, Colo., in sec. 1s, T. 15 S., R. 87 W.

\begin{tabular}{|c|c|c|}
\hline . & Ft. & \\
\hline Sandstone. & 7 & 10 \\
\hline Shale............. & 2 & 3 \\
\hline Sandstone..... & 4 & 1 \\
\hline Shale...... & 7 & 10 \\
\hline Sandstone..... & 6 & 4 \\
\hline Shale.............. & 44 & 1 \\
\hline Coal.............. & 4 & $7 \frac{1}{2}$ \\
\hline 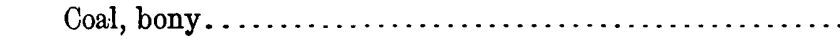 & 1 & \\
\hline 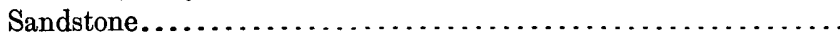 & 1 & \\
\hline 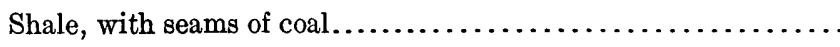 & 1 & 10 \\
\hline Sandstone. & 81 & \\
\hline
\end{tabular}

Locality No. 83.-At locality No. 83 a small exposure of rocks was found showing a coal bed 9 inches thick, but no evidence of its relations to other coal beds of the field was found except the altitude of the outcrop, which is such as to suggest that the bed may be coal No. 3 of the Mount Carbon field.

Locality No. 84.-Few rock exposures were found south of the La Plant mine for a distance of about 3 miles, but at locality No. 84, in sec. 36 , T. 15 S., R. 87 W., of the projected land net, the opening to an old mine was found. The entry was caved and inaccessible, and no coal was seen at the outcrop, but the size of the dump indicates that a prospect entry of considerable length had been driven 
in on the coal bed. Mr. La Plant states that the opening was accessible until about two years ago (1907) and that he had measured 11 feet of coal in it. The coal bed is probably the same as that opened in the next two localities toward the south.

Locality No. 85.-At locality No. 85, in sec. 31 , T. 15 S., R. 86 W., of the projected land net, an old prospect entry was found to be accessible for about 75 feet. At the end of this entry 7 feet 11 inches of clean coal was found with shale both above and below it. The coal is bituminous and relatively soft, but this softness may be due in part to weathering in the walls of the entry, which have been exposed for many years. It is supposed to be a coking coal, but such samples as could be obtained do not respond to the field tests for coking coal.

A sample of the coal was taken for analysis from a freshly cleared face 50 feet from the mouth of the entry, where the bed is 8 feet thick. Doubtless the coal has deteriorated greatly from exposure. The results of the analysis are given as No. 8620 of the table of analyses on page 206 .

The coal bed is near the base of the coal-bearing formation, but no rocks underlying the coal are exposed near the old mine, and its exact location in the stratigraphic section was not determined. About 30 feet of overlying rocks are exposed consisting of shale with thin seams of sandstone, which yielded Halymenites major, and calcareous shale from which were collected Anomia sp., Inoceramus barabini, Cardium speciosum, and Mactra sp. These are characteristic fossils of the Bowie or marine and brackish-water member of the Mesaverde and render it probable that the coal is the lowest bed in the Mount Carbon district, or coal No. 1.

Locality No. 86.-The same bed has been opened a little farther south at locality No. 86 , where the following section was measured in a prospect entry long since abandoned:

Section of coal bed at locality No. 86, in sec. $31, T .15$ S., R. 86 W.

Shale.

Ft. in.

Coal. .................................... 9

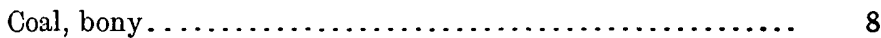

Shale.

No coal was seen south of this abandoned prospect, but coal "blossom" and old prospect openings now filled with slide rock indicate that the bed probably extends at least one-half mile south and west of locality No. 86. No coal-bearing rocks were seen beyond this point. According to local report, no indications of the coal have ever been found south of Sawmill Creek, and Mancos shale was observed there at no great distance below masses of igneous rock that appeared to be in place. 
None of the higher coal beds that occur farther north in the Mount Carbon field was found in this southwestern limb of the field, but they will probably be found in some localities, although the coalbearing rocks were more or less eroded previous to the deposition upon them of the West Elk breccia. The surface consists of grassy and brush-covered slopes, and not only is it impossible to traverse the outcrops of the coal beds, but the contact between the sedimentary rocks and the overlying volcanic breccia can be seen in only a few places.

Locality No. 8\%.-Coal is mined at Mount Carbon, a small town situated at locality No. 87 in the valley of Ohio Creek. The Alpine mine, operated by the Rocky Mountain Fuel Co., is located at this place at the end of a branch of the Colorado \& Southern Railway. The pit mouth is located in the SW. $\frac{1}{4}$ sec. 7, T. 15 S., R. 86 W., and the developed area lies mainly in the SE. $\frac{1}{4}$ of the same section The bed has been prospected at short intervals along the outcrop toward the south and east, and a tunnel has been driven on the coal bed eastward through the hill to the opening marked locality No. 92 . The bed thus extends through the hill between Ohio Creek and Carbon Creek but is lightly covered with younger rocks and is faulted as shown in figure 22.

No records of shafts or drill prospects extending below the main coal bed near Mount Carbon were obtained, but at locality No. 92 the stratigraphic relations are clear, and the bed is known to be coal No. 2, which lies about 85 feet above the top of the basal or Rollins sandstone. Bed No. 1 was found at localities to be described later, and a bed that may possibly be coal No. 3 is exposed at the top of the Alpine mine shaft 160 feet above the main bed. No other coal was encountered in this shaft.

As previously described, coal No. 1 is in the marine and brackishwater beds that overlie the Rollins sandstone, but coal No. 2 in which the Alpine mine is developed is in the Paonia member of the Mesaverde, or rocks of fresh-water origin, as shown by its association with fossil plants, which are especially numerous in the roof shale. The roof of the mine consists of sandstone in some places and of shale having a maximum observed thickness of 4 feet in other places. It is not jointed and usually falls in plates although occasionally in irregular slickensided masses. The gangways are timbered with props and crossbars and the rooms with props and caps. The roof shale does not crumble badly in the mine but "slacks" readily where it is exposed to freely, circulating air. It parts readily from the coal in the process of mining and yields no gas so far as known. No horsebacks or other irregularities have been noted, but some pyrite bowlders occur.

The product is a good variety of clean, dry, bituminous coal, relatively hard and black, with dull vitreous luster, seamy texture, and 
conchoidal fracture. It does not weather badly on exposure to the atmosphere and stands shipping without detrimental effects. The rocks in and near the mine have been faulted more or less, but the faults apparently have had little effect on the quality of the coal.

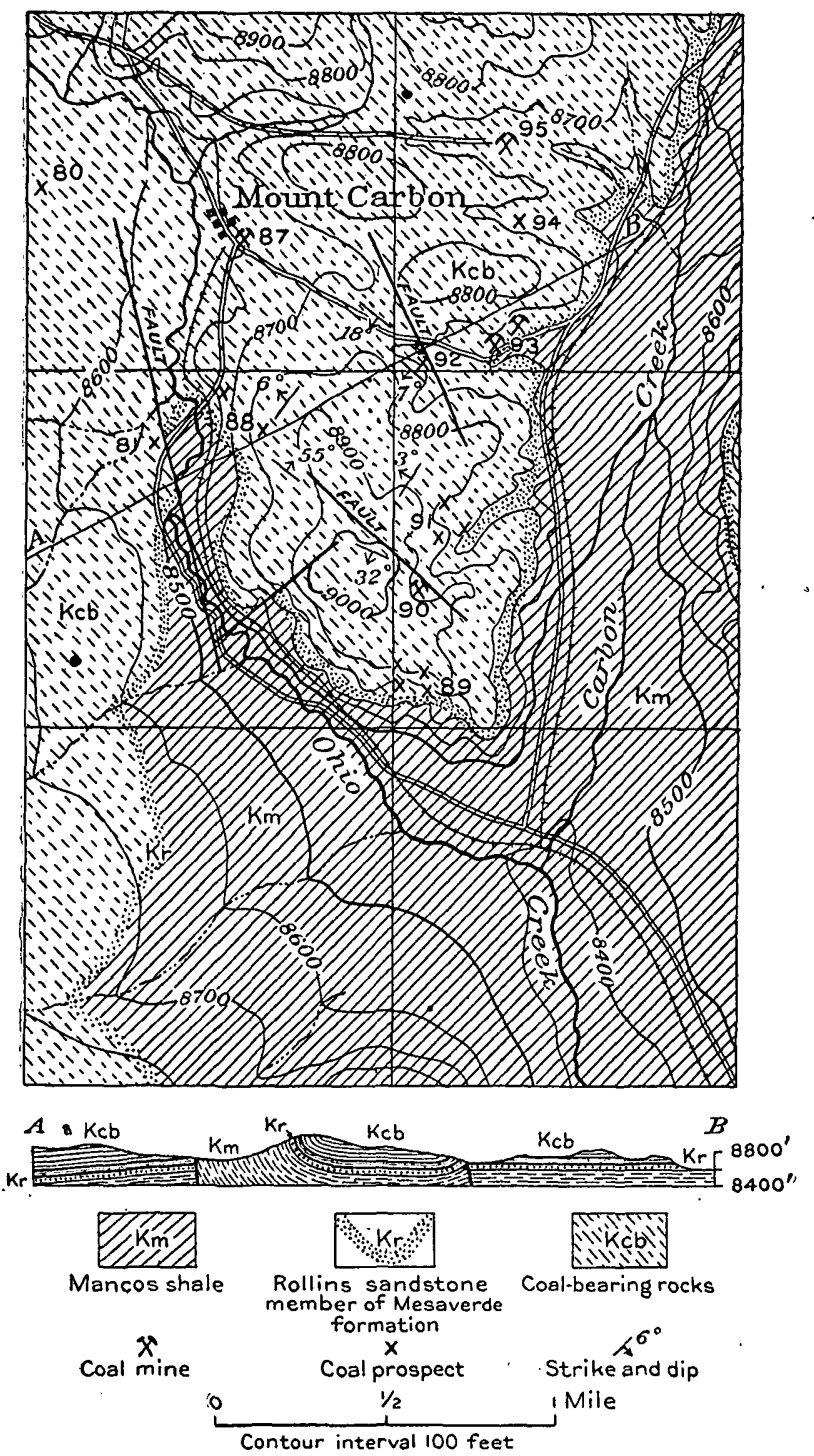

Frgure 22.-Map and section of Mount Carbon, showing faults and their effects on the coal beds.

A sample of coal was taken for analysis from a working face in the mine at a point where the clean coal is 6 feet $10 \frac{1}{2}$ inches thick. The results of the analysis are given as No. 8618 of the table of analyses on page 206. 
The character of the bed is indicated by the sections shown in figure 23. The measurements were made in the mine at points as widely separated as possible and show the uniformity in thickness of the bed in the developed area. The bed has no persistent partings or bedded
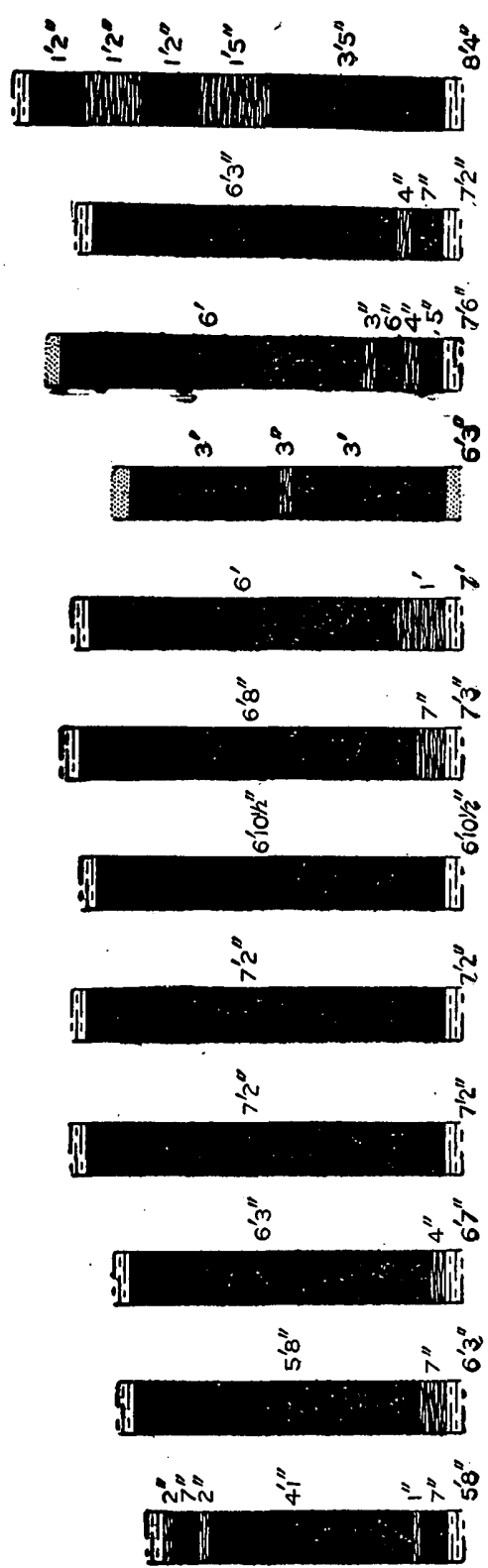

impurities, and the coal forms a clean mass between 6 and 7 feet thick. . The joint structure is well developed. The strike of the bed where measured is $\mathrm{N} .40^{\circ} \mathrm{E}$. and the $\operatorname{dip} 6^{\circ} \mathrm{NW}$., but the direction of both strike and dip varies somewhat. The direction of the cleat faces in one place is $\mathrm{N} .55^{\circ} \mathrm{W}$. and in another place N. $50^{\circ} \mathrm{E}$. The faces are well developed and extend through the bed but vary greatly in number from place to place. In some places they are close together, in others at considerable distances apart. They are developed so perfectly that they are of great assistance in mining, since the coal parts freely along them when it is undercut.

The floor of the mine consists of shale 6 inches to 1 foot thick, which ranges in character from hard bony material to soft clay shale that occasionally heaves to some extent in the rooms and gangways. Sandstone occurs below the shale. The mine is situated between two faults shown on the accompanying map. The coal has been mined up to the fault face on the south, but the north fault has not been reached in the mine, and its position on the map is determined from surface indications.

The entrance to the mine is by a three-compartment shaft 7 by 15 feet in cross-section and 157 feet deep. From the bottom of this shaft the main slope has been driven on the coal bed about 2,500 feet in a southeasterly direction, or up the rise, and gangways have been turned 
from it in either direction. The general system of mining is by roomand-pillar, the gangways being driven with triple entry on the butts and the rooms on the cleat faces of the coal. The mine is dry, and no ditching for drainage is required. The rooms are 20 feet wide where the coal is mined by hand and 30 feet wide where machines are used. The gangways are placed 300 feet apart, and the rooms are driven up the rise 245 feet, or to within 55 feet of the neighboring gangway. Between the rooms 24-foot necks are left, and the rooms are timbered with props and caps or crossbars according as the condition of the roof requires. The pillars are drawn by the retreating method. Since there are no partings in the coal and no waste material is removed in mining, there are no gob pillars, and the old workings are entirely closed when the pillars are drawn.

The Alpine mine is ventilated by means of a propulsion fan 4 by 14 feet in size, and the air is distributed by the splitting method with overcasts, brattices, etc. Little gas has been detected in the mine and open lights are used at the working faces, although the main entry and gangways are lighted with electricity. Although little water is present, the mine is so laid out that drainage is toward a sump, where the water is pumped out by means of a Cameron No. 9 pump situated at the bottom of the shaft and operated by steam.

In some parts of the mine the coal is undercut by hand, in which case a cut is made 3 feet deep. In other parts machines are used that undercut to a depth of 6 feet. If the cleat faces are well developed, the coal snaps from the breast and falls of its own weight. If the faces are not well developed, the coal is either wedged or shot down. In still other parts of the mine the coal is shot from the solid with black powder. Mules are used for gathering the loaded mine cars, and an electrically operated rope is used for haulage in the gangways and for lowering the cars in the main slope to the foot of the shaft. The capacity of the mine at the time of investigation was said to be 600 tons a day. One hundred wooden mine cars having an average capacity of 2,600 pounds are in use. The shaft consists of one air and two hoisting compartments, although only one of these is now used, and is fitted with single deck cage, safety appliances, straight pull wire, and electric signals.

The coal after being weighed in the mine cars passes over a barscreen with 1-inch apertures, which separates it into lump and slack, and these are loaded directly on the railway cars at the bottom of the tipple. The loading is facilitated by means of box-car loaders. Very little picking is necessary. The coal is used chiefly as a domestic fuel, although some of it is used as a steam coal for railway locomotives.

Locality No. 88.-There is an old prospect opening in coal bed No. 2 about one-half mile south of the Alpine mine opening, but the old entry was inaccessible at the time of investigation. At locality 
No. 88 the following section of this bed was measured in a prospect opening:

Section of coal bed in Mount Carbon field at locality No.88, in sec. 18, T.15 S., R. 86 W.

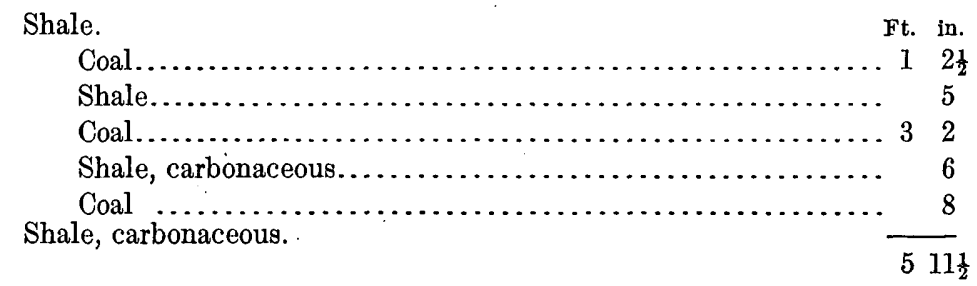

The prospect is close to a fault and the bed dips $55^{\circ} \mathrm{NE}$. The coal is a hard clean bituminous like that described from the Alpine mine. Coal bed No. 1 occurs at this locality a few feet above the Rollins sandstone, and the following section of it was measured at the outcrop:

Section of coal bed No. 1 at locality No.88, south of Mount Carbon, in sec. 18, T. 15 S.,

Shale. R. $86 \mathrm{~W}$

Shale, carbonaceous, with thin seams of coal.............. 1

Shale.

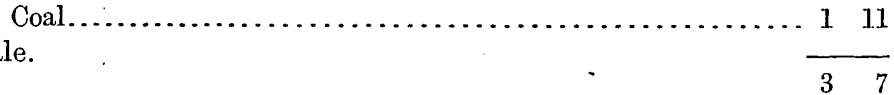

Locality No. 89. - South of locality No. 88 a fault trends N. $55^{\circ}$ E. with downthrow to the north, bringing the beds that outcrop near the top of the bluff on the southeast down to the level of Ohio Creek north of the fault line. Coal beds No. 1 and No. 2 were followed from this fault eastward, and at locality No. 89 the lowest coal or bed No. 1 was found a few feet above the Rollins. It contains 2 feet 9 inches of bituminous coal with shale above and below it. An old
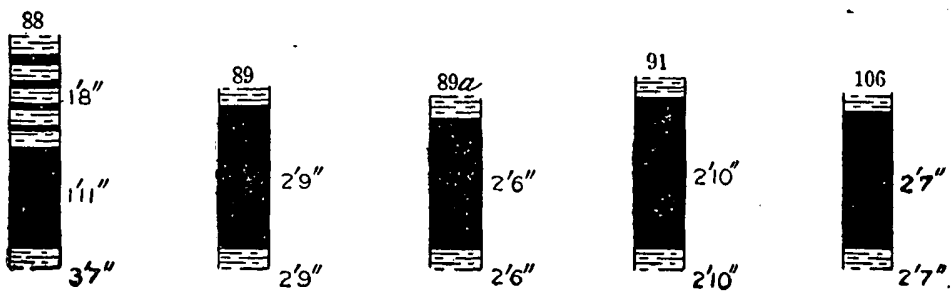

Figure 24.-Sections of coal in bed No. 1, Mount Carbon field.

prospect in coal No. 2 shows 2 feet 9 inches of coal beneath 6 feet of shale, but the bottom of the coal was not exposed.

About 500 feet farther east, the lowest coal has been mined in years past, and the old entry is still accessible. A thickness of 2 feet 6 inches of coal was found here with shale floor and shale roof. No. 2 bed had also been prospected near this place, but the old opening was inaccessible. A thickness of 6 feet of coal was measured . at the outcrop near the old prospect. 
Locality No. 90.-Coal No. 2 has been developed in the BaldwinStar mine at locality No. 90, and 6 feet of clean bituminous coal with shale floor was seen, but the top of the coal was not found. The mine was temporarily abandoned at the time of investigation, and no information regarding it was obtained. Several old prospects as well as surface exposures found north of the mine indicate that the coal bed is steeply upturned and displaced by faulting.

Locality No. 91.- In the same gulch in which the Baldwin-Star mine is situated and a little north of this mine, at locality No. 91, coal No. 2 has been opened in a mine that was temporarily abandoned at the time of investigation. The bed here consists of 7 feet 9 inches of clean bituminous coal with shale floor and shale roof. It dips $3^{\circ} \mathrm{NW}$. and the direction of the cleat faces is N. $55^{\circ} \mathrm{E}$.

Coal bed No. 1 occurs in this locality 5 feet above the top of the Rollins sandstone and contains 2 feet 10 inches of coal with shale
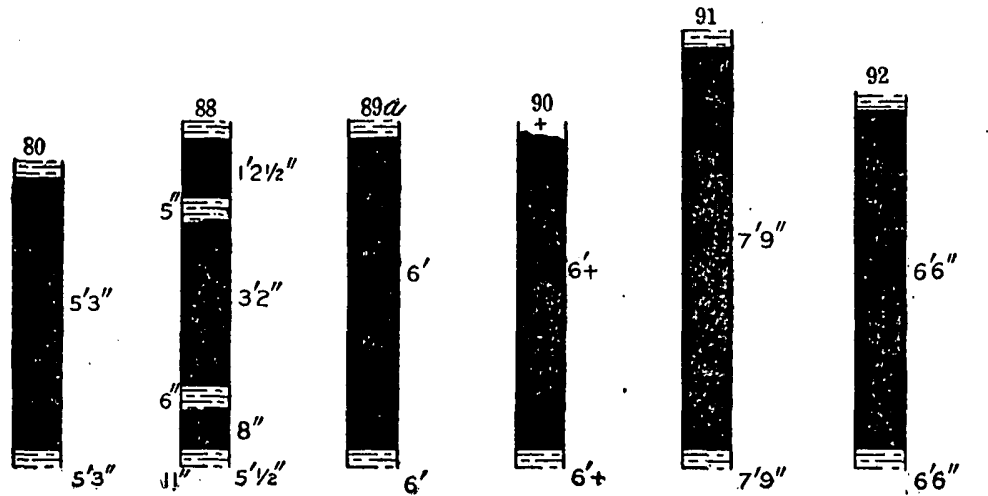

Figure 25.-Sections of coal in bed No. 2, Mount Carbon field.

above and below it. This coal has evidently been mined in years past, but the old entry was inaccessible, and the measurement was made at the outcrop near the old opening.

Locality No. 92.-In the first gulch north of the Baldwin-Star mine, at locality No. 92, is the eastward opening of the Alpine mine. The bed here has a thickness of 6 feet 6 inches of clean hard bituminous coal. The dip at the surface is $7^{\circ} \mathrm{NW}$., but the degree of dip becomes less farther from the fault that passes east of the prospect. The cleat faces trend N. $47^{\circ}$ W. At this locality carbonaceous shale was noted above the basal or Rollins sandstone, but no coal was found at the horizon of bed No. 1. This sandstone is brought to the surface by faulting, as shown in figure 22, page 153 .

Locality No. 93.-Farther east in the same gulch, at locality No. 93, there is an abandoned mine on coal bed No. 2 that was inaccessible at the time of the investigation, and nothing was learned of it farther than that the coal is reported as 6 to 7 feet 
thick. From the size of the dump and the presence of tipple, old mine cars, and trackage, the inference is drawn that a considerable amount of coal has been mined here in years past.

Locality No. 94.- The next locality toward the north at which coal was observed is No. 94. Here the following section was measured in an old opening in coal bed No. 2:

Section of coal bed at locality No.94, near Mount Carbon, in sec. 8, T. 15 S., R. 86 W.

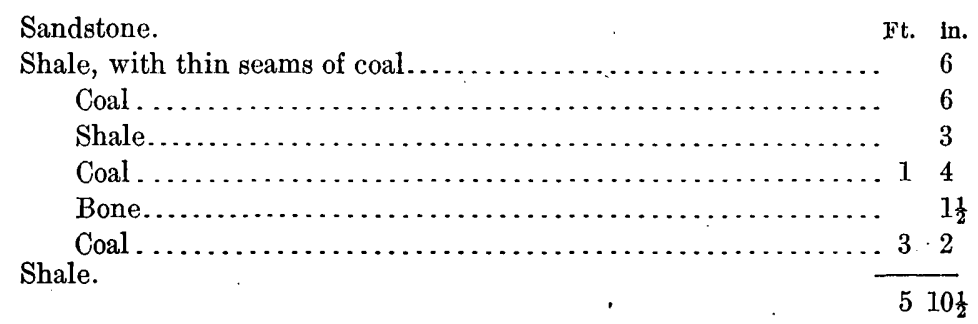

This is apparently one of the openings of the old Baldwin mine, which is no longer in operation, and nothing further was learned of the prospect.

Locality No. 95.-At locality No. 95 is the old Baldwin mine. Coal was reached at this place by shaft, and the old hoist together with some of the abandoned buildings remain to indicate that a considerable amount of mining was once carried on; but the place is now deserted and nothing further was learned in the field of this mine. Hills ${ }^{1}$ states that in 1892 it was the only mine operated in the Mount Carbon field. He states further that the coal is 5 to 6 feet thick, dips $5^{\circ} \mathrm{W}$., and "is an excellent slightly coking domestic fuel." - He also states that this bed increases in thickness to 6 or 7 feet toward the south and decreases to 4 feet in an opening farther north.

The coal of bed No. 1 was not seen near locality No. 95, but in the west bank of Carbon Creek, about halfway between this locality and the Kubler mine, locality No. 100, coal "blossom" appears at the horizon of this coal, and an old prospect now closed had been run in on the bed. Eldridge states, in Folio 9, that all three beds occur in the Baldwin region and that "All vary in thickness but range from 3 to 6 feet."

Locality No. 96.--In the west bank of Carbon Creek at the base of Mount Carbon, locality No. 96, the coal-bearing rocks, a thickness of 30 feet of which are exposed, underlie the igneous rocks of the Mount Carbon laccolith and dip $4^{\circ}$ due north. A bed of coal with shale roof and floor is exposed for a distance of several hundred feet and ranges in thickness from 3 feet 6 inches to 4 feet 11 inches. The coal is apparently bed No. 2, but nothing was found that definitely

1 Hills, R. C., Coal fields of Colorado: Mineral Resources U. S. for 1892, U. S. Geol. Survey, 1893, p. 348. 
fixes its horizon. It is of bituminous quality and similar in general appearance to the coal of Alpine and Kubler mines but harder than these coals, and shows some indications of coking. The bed is only about 100 feet from the igneous contact, and the hardness of the coal may be due in some measure to metamorphism caused by the intrusion of the igneous rock. However, the shale associated with the coal shows little evidence of metamorphism.

An old entry at this locality is still accessible for a short distance, and an old tipple, track, and mine cars indicate that a considerable amount of development work was done. The rocks are faulted and otherwise disturbed, and surface indications suggest that the disturbed condition of the rocks may have rendered further development impracticable.
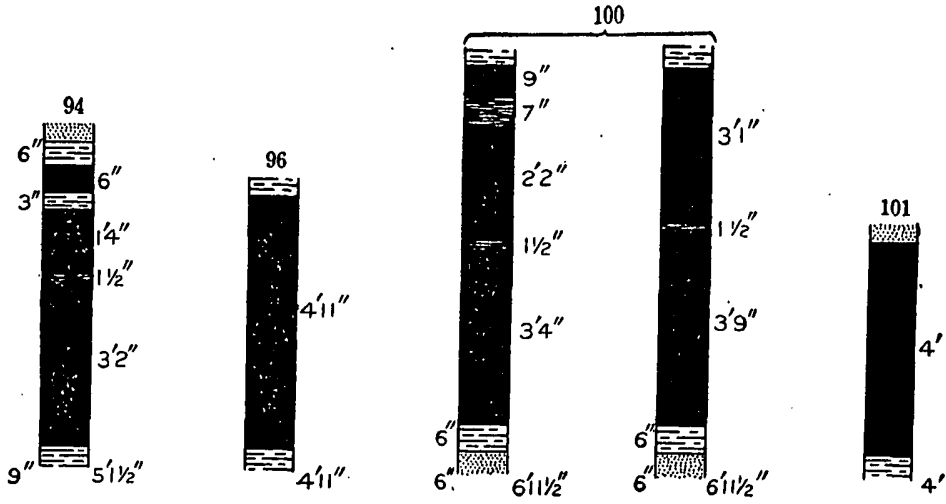

Figure 26.-Sections of coal in bed No. 2, Mount Carbon field.

The quality of the coal at this locality is indicated by the following analysis quoted from United States Geologic Folio No. 9:

Proximate analysis of coal from abandoned mine east of Mount Carbon, Colo.

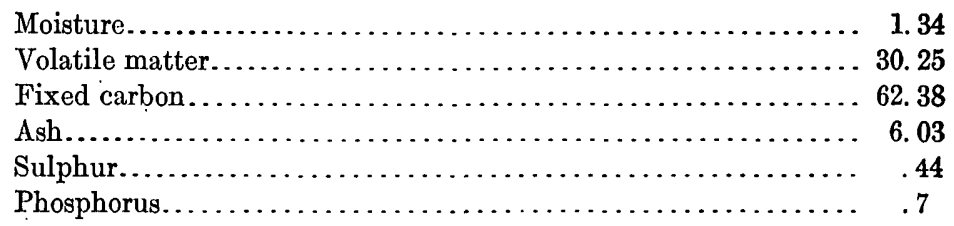

Localities Nos. 97-99.-Coal bed No. 2 has been opened at localities Nos. 97, 98, and 99, and judging from surface indications considerable development work has been done at the first two of these localities. At locality No. 97 the upper 3 feet of coal and the shale above were seen, but the old entry was partly filled with water, and no further details could be obtained. The roof of the entry at locality No. 98 had fallen, and the base of the coal bed was not found. However, a thickness of 5 feet of coal was seen overlain by one foot of shale above which is a sandstone ledge. At this locality the coal bed 
was found by surface measurements to be about 85 feet above the top of the basal or Rollins sandstone. This measurement, although made with hand level on a brush-covered slope, is probably correct to within a few feet, as no faulting or other disturbances of the rocks were observed that could vitiate the result. At the horizon of coal bed No. 1, carbonaceous shale was found but no coal. At locality No. 99 coal bed No. 2 has been prospected, but the opening was not accessible at the time of investigation, although surface indications show that the bed has about the same thickness that it has in neighboring localities on either side.

Locality No. 100.-At locality No. 100, in sec. 4, T. 15 S., R. 86 W., of the projected land net, is situated the Kubler mine. The mine was opened about 1895 and operated for a few years. Recently it has been reopened and equipped with machinery, trackage, etc. The entrance to the mine is by slope, the mouth of which is located in the south wall of Kubler Gulch, an east side tributary to Carbon Creek. The main entry had been extended northeasterly about 4,000 feet at the time of investigation, and active mining operations were being carried on. The base of the coal measures is not exposed at the mine, but the coal bed is traceable to it with slight interruptions from the old openings at localities Nos. 97, 98, and 99, which are known to be in coal bed No. 2. The shale overlying the coal contains great numbers of fossil leaves of deciduous species, and palm leaves, Geonomites ungeri Lesq., were collected from the first sandstone layer above the coal. These fossils are regarded as sufficient evidence that the coal is in the Paonia or fresh-water member of the Mesaverde.

In some places the roof of the mine is sandstone, but over most of the area thus far developed the roof is shale and attains a maximum observed thickness of 4 feet. There is no regular draw "slate," but in places more or less of the shale is removed in mining. It is affected by slips and crumbles badly when exposed to the air. It falls in some places in the form of plates and in other places as "pots" and irregular slickensided masses. It usually clings to the coal, though in some places it parts from it somewhat readily in the process of mining.

The coal is a hard, bright bituminous, of good quality, and does not differ notably from that of the Alpine mine previously described. There are seams of bone that are relatively persistent, but the coal parts from them readily, and they do not interfere seriously with mining operations. The bed is very regular in thickness over the developed area and is adequately represented by the following sections. Section 1 was measured at the end of the main entry, which is about 4,000 feet long, and section 2 about halfway between this and the mouth of the entry. 
Sections of the coal beds in the Kubler mine, in sec. 4, T. 15 S., R. $86 \mathrm{~W}$.

No. 1.

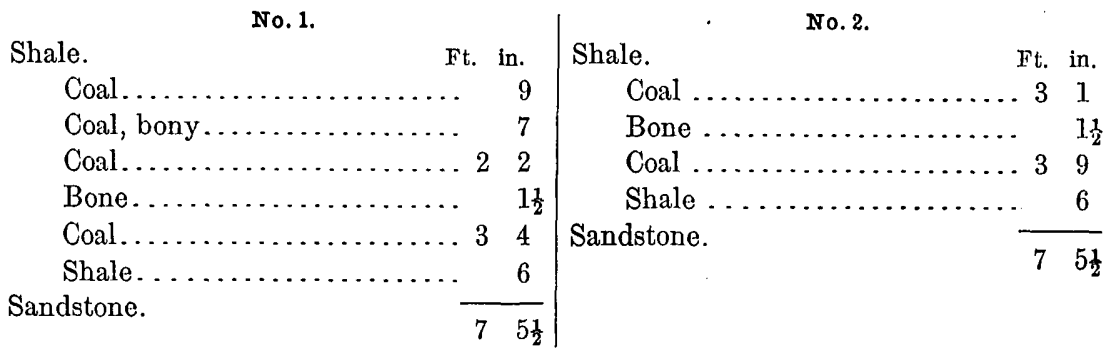

A sample of coal was taken for analysis from a working face near the point where the first of the above sections was measured and includes 7 feet 2 inches of coal. The results of the analysis are given as No. 8617 of the table of analyses on page 206 .

The floor of the mine consists of shale 6 inches thick underlain by sandstone. The shale is carbonaceous and contains thin seams of coal. No tendency to creep or heave has been noted. The general dip of the bed is about $3^{\circ} \mathrm{NW}$. and the strike is N. $35^{\circ} \mathrm{E}$.

The entrance to the mine is by double entry slope driven on the coal bed diagonally up the rise. The general system of mining is roomand-pillar and is laid out with reference to the natural inclination of the rocks, so that the mine drains toward the mouth, and the water is discharged through a side tunnel leading from the main entry into Kubler Gulch. The timbering is by props and caps, props and crossbars being used where the character of the roof demands extra support. The pillars are drawn by the retreating method.

Some of the coal is undercut by machines, but most of it is shot from the solid with black powder. The mine haulage is by mules to the head of the main entry, and the cars of coal are lowered by rope over a gravity incline to the tipple. The mine is ventilated by means of a furnace placed at the foot of an air shaft; but this will be supplanted by a 10-horsepower electrically driven, $5 \frac{1}{2}$-foot propulsion fan, which was about to be installed at the time of investigation. The mine is not dusty, and little gas has been detected. Open lights are used at the working face.

At the tipple, which is situated at the foot of an incline leading from the mouth of the mine, and which is a continuation of the underground slope in the main entry, the coal is screened into lump (49 per cent), which includes pieces of coal over 2 inches in diameter; nut (21 per cent), which includes fragments between 1 and 2 inches in diameter; and slack ( 30 per cent). The tipple is provided with a box-car loader and the coal is loaded directly into railway cars for shipment. No provision is made for storage. The coal is used principally as a domestic fuel.

$40642^{\circ}-$ Bull. $510-12-11$ 
Nothing was learned of coal No. 1 near locality No. 100, but the superintendent of the mine states that a 2 -foot bed of coal was penetrated by the air shaft of the Kubler mine 42 feet above the main coal, or bed No. 2. This may be coal No. 3 of the Mount Carbon field, but more probably it is one of local occurrence, for coal No. 3 at the Alpine mine about 2 miles from Kubler is 160 feet above coal bed No. 2.

Locality No. 101.-East of Carbon Creek and south of Kubler mine coal bed No. 2 has been prospected in several places, but in only one place was the coal exposed at the time of investigation. At locality No. 101 there was found 4 feet of coal with sandstone above and shale below. A fault near this locality brings the basal or Rollins sandstone to the surface, and Halymenites major and other characteristic fossils were collected from it. But coal No. 1, which if present should occur near the top of this sandstone, was not found.

Locality No. 102.- South of this locality coal "blossom" was observed in several places at the horizons of coal beds, Nos. 1 and 2, but no undisturbed coal was seen for a distance of nearly a mile. In sec. 10, T. 15 S., R. 86 W., of the projected land net an old prospect was found, and the following section of coal bed No. 1 was measured in it.

Section of coal bed No. 1 at locality No. 102 east of Mount Carbon, in sec. 10, T. 15 S., R. $86 \mathrm{~W}$.

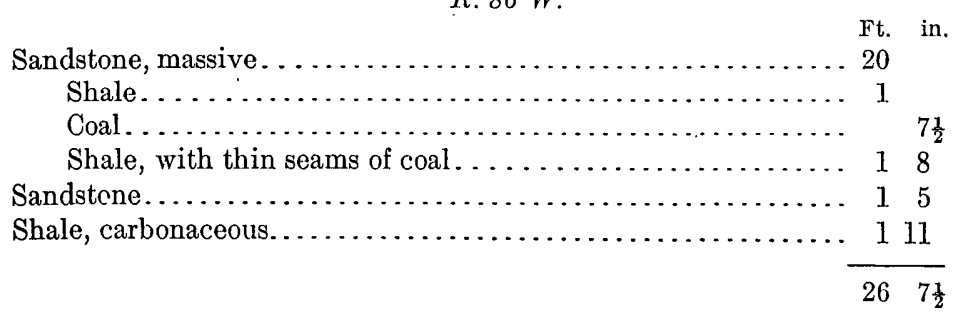

The rocks at this locality $\operatorname{dip} 6^{\circ} \mathrm{W}$. and strike N. $21^{\circ} \mathrm{E}$. The coal is a hard variety of bituminous and breaks out in blocks along the cleat faces, which are well developed and trend N. $40^{\circ} \mathrm{E}$. The supposed seaweed, Halymenites major, was found above this bed and its presence is regarded as sufficient evidence that the coal belongs to the Bowie or marine and brackish-water member of the Mesaverde, in other words, that this thin bed is the same as the lowest bed south of Mount Carbon, which at locality No. 84 is 11 feet thick.

Locality No. 103.-At locality No. 103 coal has been opened in two places in the north wall of Owens Gulch and in one place south of it, apparently in bed No. 2. The quantity of material composing the old dumps and the presence of a tipple, track, and other evidences of mining operations indicate that coal mining was once carried on at this place to a considerable extent. However, the old openings were inaccessible at the time of investigation, and nothing was learned of the character of the coal or of the thickness of the bed. 
Locality No. 104.-At locality No. 104, in sec. 10, T. 15 S., R. 86 W., of the projected land net, an old mine was found with a prospect opening 60 feet above it. The openings were caved, and nothing was learned regarding the coal. This old mine is higher than would be expected for bed No 2 and may be at the coal horizon which Eldridge states, in Folio 9, is 300 feet above the base of the coal-bearing formation. On the other hand, the rocks in this region are known to dip more or less steeply northwest, and the difference in altitude between this mine opening and those at locality No. 103 may be due to a local increase of the dip.

Locality No. 105.-For a considerable distance south of Owens Gulch the rocks are not well exposed, and the coal beds could not be followed, but in sec. 15, T. $15 \mathrm{~S}$., R. $86 \mathrm{~W}$., of the projected land net, at locality No. 105, an entry to a coal bed was found in good condition, and the following coal section (1) was measured 275 feet from the opening. A second section (2) was measured near the mouth of the entry.

Sections of coal bed east of Mount Carbon at locality No. 105, in sec. 15, T. 15 S., R. $86 \mathrm{~W}$.

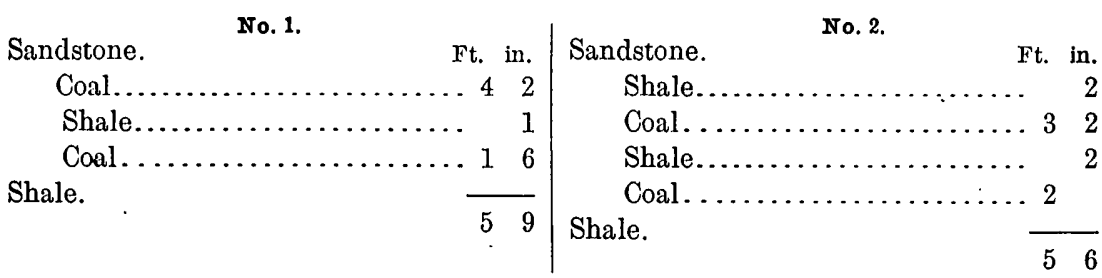

The coal is a bright, clean, hard variety of bituminous and is probably bed No. 2, although it is apparently higher in the coal-bearing formation than would naturally be expected for this bed.
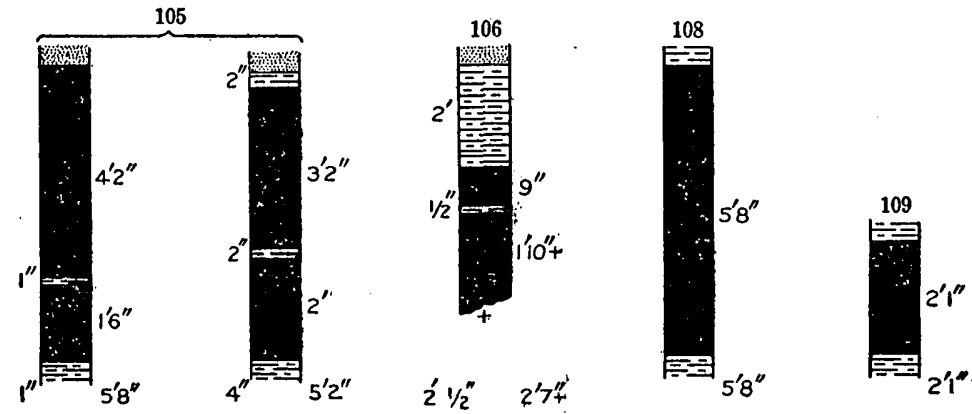

FIGURE 27.-Sections of coal in bed No. 2, Mount Carbon field.

A sample of the coal was taken for analysis at the point where the first of the sections just given was measured and includes both benches of the coal. The results of the analysis are given as No. 8616 of the table of analyses on page 206 . 
Locality No. 106.-About a mile farther east, in sec. 14, T. 15 S., R. 86 W., of the projected land net, at locality No. 106, two coal beds were found, but the stratigraphic interval between them was not satisfactorily determined. The higher bed is under a massive cliffmaking sandstone, and an old prospect opening was found at which the following section was measured:

Section of coal bed east of Mount Carbon at locality No. 106, in sec. 14, T. 15 S., R. $86 \mathrm{~W}$.

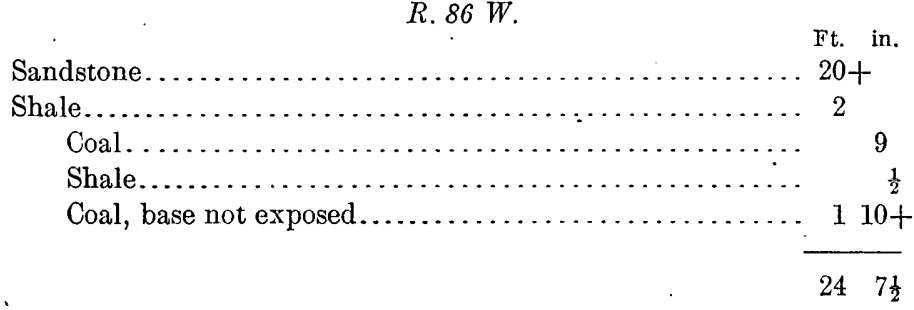

The vertical partings of the coal are well developed and the cleat faces trend N. $20^{\circ} \mathrm{E}$. Apparently the coal is a good quality of bituminous, but it is considerably weathered in the prospect entry.

The lower bed at this locality was measured at the outcrop, and 2 feet 7 inches of coal was found with shale above and below. Its position with reference to the base of the coal measures was not definitely determined because of the brushy condition of the surface, but the basal or Rollins sandstone was observed a short distance beneath it. It is probable that this is coal bed No. 1 and that the higher bed is coal No. 2 .

Localities Nos. 107 and 108.-In sec. 11, T. 15 S., R. 86 W., of the projected land net, at locality No. 107, the lowest bed was found near the base of the coal measures, but no prospecting had been done on it, and only carbonaceous shale was observed along the outcrop. At locality No. 108 a prosipect entry had been driven into solid coal, and a bed, apparently coal No. 2, was found 5 feet 8 inches thick with shale above and below.

No coal was found for a considerable distance east of locality No. 108. The coal beds probably continue under the northern part of the basalt cap of Mount Wilkinson, but from the southern part of this mountain they were eroded away before the outpouring of the igneous rock. The Mancos shale, the Rollins sandstone, and in some places a few feet of the overlying beds of the Mesaverde formation are exposed in the south embayment of the basalt sheet, but no coal was found south of the mountain.

Locality No. 109.-East of Mount Wheatstone the southernmost locality at which coal was found is No. 109 , in sec. 6 , T. 15 S., R. 85 W., of the projected land net, where coal 2 feet 1 inch thick was found with shale above and below it. Eldridge states that "the coal has been prospected at several points in its eastern face (Mount 
Wilkinson), from 3 to 4 feet showing beneath the basalt in one locality,"1 but none of these old prospects was found during this investigation. The undisturbed rocks are not well exposed in this locality. The surface is covered with slide rock from the basalt above and is densely wooded. Although the coal bed at locality No. 109 is probably near the base of the coal measures, nothing was found to indicate its exact horizon. It is similar in thickness to the bed supposed to be coal No. 2 exposed a mile farther north at locality No. 110 and is provisionally correlated with it.

Locality No. 110.-For about a mile north of locality No. 109 the rocks are covered with soil and brush and no coal was found. But near locality No. 110, in sec. 36 , T. 14 S., R. 86 W. of the projected land net, coal has been opened in several prospects in a bed, which for convenience of description may be called the Robinson coal bed. At the Robinson mine, situated in the NE. $\frac{1}{4}$ NW. $\frac{1}{4}$ sec. 36 , of this township, at an altitude of about 10,500 feet in the side of Mount Wheatstone, a considerable amount of development work has been done, and some coal has been shipped from it to market over a wagon road graded from the mine northward to the thoroughfares in Slate River valley. The formations exposed here are the Mancos shale, the Rollins sandstone containing characteristic fossils consisting of Halymenites major and marine invertebrates, and the coal measures of the Mesaverde, about 300 feet of which occur below the igneous rock of the Mount Wheatstone laccolith. Apparently coal bed No. 1 and its associated beds of marine and brackish-water origin are not present at this locality. The lowest coal bed a few feet above the basal or Rollins sandstone is associated with fossil plants of the same species as those found in the roof shale of coal bed No. 2 in Kubler mine and in the Paonia member of the Mesaverde throughout the Grand Mesa field. These plants were collected here: Sequoia reichenbachi (Gein.) Heer, Sequoia brevifolia Heer, Ficus speciosissima Ward?.

A section of the coal bed was measured in the Robinson mine 175 feet from the mouth of the opening. The bed consists generally of three benches separated by partings of shale, as described in the following section, but these partings disappear in some places. (See. also No. 110 , of fig. 28, p. 167.)

Section of coal bed measured in the Robinson mine, sec. 36, T. 14 S., R. 86 W.

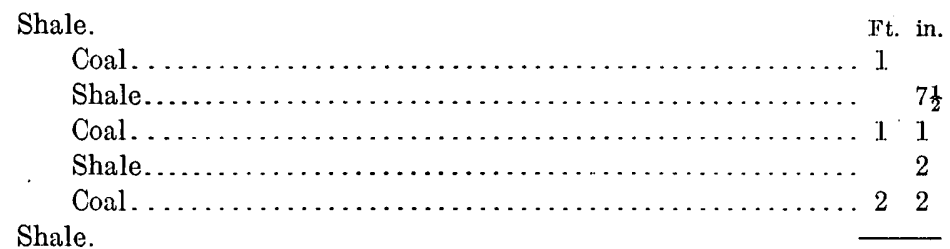

$5 \quad \frac{1}{2}$ 
A sample of the Robinson coal was taken for analysis where the coal is 5 feet 11 inches thick and near the point where the section was measured. The results of the analysis are given as No. 8246 of the table of analyses on page 207.

The Robinson coal is a clean, hard, bright anthracite, probably metamorphosed from the bituminous coal of this field by the heat from the igneous rock of the Mount Wheatstone laccolith. A few hundred feet south of the mine a prospect opening has been made in which the following section was measured. '(See also No. 110-a, of fig. 28.)

Section of coal bed near Robinson mine, sec. 36, T. 14 S., R. 86 W.

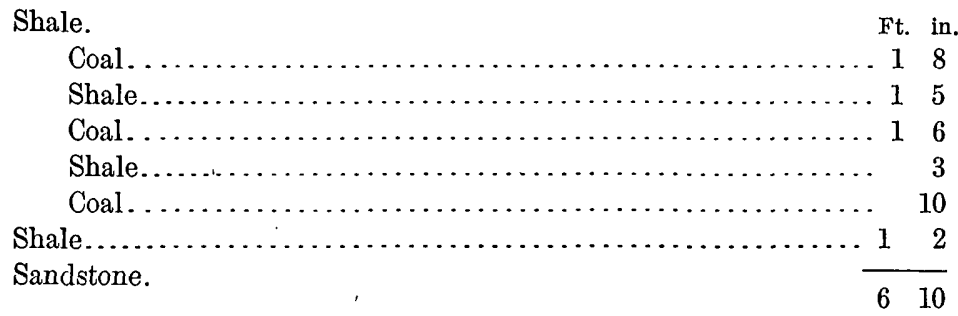

At this place the Rollins sandstone with its characteristic fossils is well exposed, and the Robinson coal is separated from it by only 14 inches of shale. About 20 feet of sandstone and shale in alternating layers and containing many fossil plants are exposed above the coal.

This coal bed has been prospected in several places along the outcrop south of the Robinson mine and found to continue for a considerable distance with unimportant variations in thickness. About a quarter of a mile south of the mine, however, the lowest bed, 14 inches above the Rollins sandstone, is 2 feet 6 inches thick (see section $110-b$, fig. 28), and is overlain by shaly sandstone from which a number of fossil plants were collected. The rocks above this prospect are not exposed, but in an old opening 50 feet higher in the formation a bed of coal 2 feet 6 inches thick was found with shale above and below it, as described in the following section:

Section of coal bed in an old prospect south of the Robinson mine, sec. 36, T.14 S., R. $86 \mathrm{~W}$

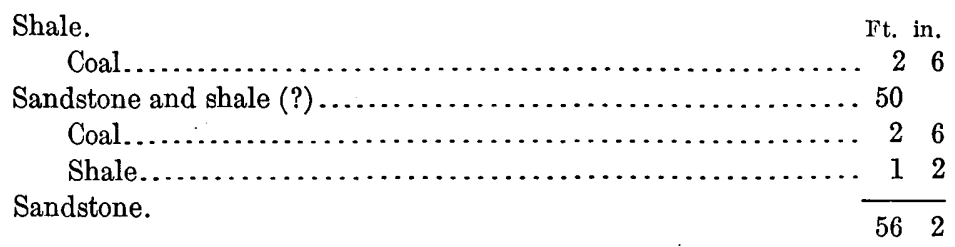

This bed lying 50 feet above the Robinson cual was not observed elsewhere in this region, and its interpretation is not clear. The interval of 50 feet between the two beds is too great to admit of a 
probability that they represent the two benches found in the Robinson mine and that the shale parting has increased to 50 feet in the distance of a quarter of a mile. It is possible that there is only one bed here and that it is faulted and displaced 50 feet, but no evidence of a fault was found. The only other known occurrence of coal at this horizon is in the air shaft of Kubler mine, where a 2-foot coal bed was penetrated 42 feet above the main coal.

At a horizon about 250 feet above the Robinson coal, a prospect was opened in a coal bed 2 feet 6 inches thick with shale above and below it. Apparently this is coal No. 3 of the Mount Carbon field described by Eldridge in Folio 9. This coal had been opened in several prospects near this locality, but the old openings were inaccessible at the time of investigation. 'The quantities of slide rock at these places rendered it impracticable to reopen the prospects and nothing further was learned of the bed.

At a horizon 55 feet above the coal just referred to, a bed had been prospected; but on reopening the old prospect only black carbonaceous shale was found. The character of the shale, however, is such as to render it probable that coal may occur at this horizon in some places.

Locality No. 111.-West of the divide near the Robinson mine, a broad, shallow valley has been eroded in the coal-bearing rocks,

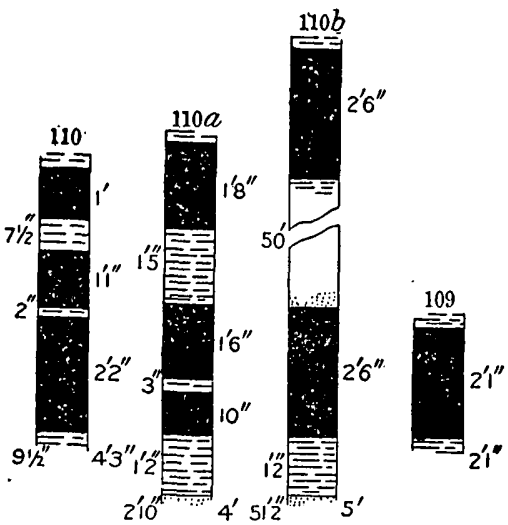

Figure 28.-Sections of coal in Robinson mine and prospects at east end of the Mount Carbon coal field. cutting them away to some undetermined depth below the highest coal just described and in one place at least (locality No. 111) reaching. a bed that is correlated with the Robinson coal. No coal was found in place in this valley, but at this locality, No. 111, there is an old, abandoned, and inaccessible entry, and pieces of anthracite coal were found on the old dump.

Locality No. 112.-At locality No. 112 carbonaceous material was observed on the dump of an old abandoned mine near a shaft that apparently had been sunk to a coal bed. This shaft was open to a depth of 30 feet, but below that it was filled with water and nothing further was learned of the old prospect. The altitude of the surface at this locality is much lower than it is at the lowest coal bed of the Robinson mine, but the rocks dip about $15^{\circ} \mathrm{W}$., and the coal bed is probably the same as the one in which the Robinson mine is located. 


\section{CRESTED BUTTE COAL FIELD.}

(Nos. 113-136.)

\section{GENERAI STATEMENT.}

The Crested Butte coal field lies in the valley of Slate River at the eastern extremity of the Grand Mesa and West Elk Mountain region. It is separated from the Grand Mesa field on the west by the Ruby Range and from the Mount Carbon field on the.south by Mount Wheatstone and Mount Axtell. The coal beds are readily accessible in Slate River valley near Crested Butte, where they outcrop near the level of the valley floor and where the largest mine of this field is situated, but for the most part they outcrop high in the canyon walls and are difficultly accessible, as has been stated in the section describing the surface features and their influence on mining industry. Toward the southeast. from the town of Crested Butte the coal outcrop rises rapidly in the side of Gibson Ridge, and toward the northwest it ascends to altitudes of more than 10,000 feet in Anthracite Mesa, 11,000 feet in Oh-be-Joyful Gulch, and nearly 11,500 feet in Baxter Basin, where the coal at the outcrop reaches a maximum altitude of about 2,500 feet higher than the town of Crested Butte.

With the exception of the area south of Crested Butte, the coal beds have a general southerly inclination and pass beneath younger rocks to depths of 3,000 or 4,000 feet below the surface. This general inclination is due to the Treasury Mountain uplift previously described in the section entitled "Geologic structure." The dip and strike of the beds have been modified in many places by local folding, warping, and faulting, and by the intrusion of numerous dikes and sheets of igneous rock.

In Anthracite Mesa the general inclination is toward the south, but the coal beds have been greatly disturbed by faulting and folding. In some places along the northern border of the mesa the beds are upturned to a nearly vertical position, and at least two faults trending northeast and southwest cross the mesa. Lateral thrust presumably accompanying this folding has so crushed the coal that mining has been found unprofitable, and the mine at Anthracite was abandoned. Apparently two epochs of dynamic movement have affected the coal of Anthracite Mesa. The first movement caused the metamorphism of the coal from bituminous to anthracite and the second movement crushed the anthracite coal. The crushed coal, or "slack" as it is locally termed, could not have been produced by the same movement that metamorphosed the coal, else the fragments would have been fused together. The fact that the "slack" consists of powder or small separate pieces of anthracite coal indicates that the crushing took place after the metamorphism of the coal was complete. 
West of the town of Crested Butte and south of Slate River, the beds incline rather steeply toward the southwest and descend to depths of probably more than 3,000 feet beneath the surface. The coal beds were brought to the surface again farther south by the upthrust of Anthracite Range. East of this range there is another small area in which the coal seems to be more than 3,000 feet beneath the surface of Mount Axtell. Apparently the beds underlying the mountain mass have been bowed downward by the weight of the mountain as the rock tended toward the establishment of isostatic equilibrium.

South of the town of Crested Butte the general inclination of the stratified rocks has been reversed by the intrusion of the laccolithic mass of Mount Wheatstone, which has upturned the coal beds toward the north and probably also toward the west. The trough of the syncline thus formed is exposed in Slate River valley near the town of Crested Butte, and it is due to this syncline that the coal beds are there brought down to the level of the valley floor. So far as is now known, the trough of this syncline is the dividing line between the areas containing bituminous coal on the southeast and those containing anthracite on the northwest.

The sedimentary formations that were examined in detail in the Crested Butte field are the Mancos shale and the Mesaverde formation: The Mancos is the same as the shale that Eldridge, in Folio 9 of the Geologic Atlas of the United States, calls Pierre but is here correlated on fossil and stratigraphic evidence with the Mancos shale of the Grand Mesa field on the west. This shale is overlain by a massive white sandstone, which constitutes the basal member of the Mesaverde and is here correlated on fossil and stratigraphic evidence with the Rollins sandstone of the Grand. Mesa field. It is not so prominent in this field as it is in the Grand Mesa field but can usually be identified by its characteristic fossils, most conspicuous among which is the supposed seaweed, Halymenites major. Eldridge referred. this sandstone to the Fox Hills.

A coal bed is usually found either resting directly upon this sandstone or separated from it by a few feet of shale. No fossils were found associated with this coal, but in one place where the coal does not occur fossil plants were found in rocks a few feet above the Rollins sandstone. A second coal bed lying about 75 feet above the lowest coal has yielded abundant fossil evidence that it and the rocks associated with it are to be correlated with the Paonia member of the Mesaverde in the Grand Mesa field. The association of fossil plants with the lowest coal at locality No. 110, at the east end of the Mount Carbon field, warrants the supposition that the lowest coal bed in the Crested Butte field may also be of nonmarine origin and that no rocks occur in this field that can be correlated with the Bowie 
member of the Mesaverde. This supposition is strengthened by the absence from the Floresta field previously described of rocks referable to the Bowie member.

The evidence now in hand indicates that the coal-bearing rocks above the basal or Rollins sandstone are equivalent in age to the Paonia or fresh-water member of the Mesaverde and are correlated on fossil and stratigraphic evidence with the beds of this member in the Grand Mesa field. They consist of sandstone and shale, the latter predominating, and are eroded easily as compared with the overlying rocks, which are predominantly sandstone. Ten partial geologic sections were measured in the Crested Butte field in order to determine the horizons at which coal occurs in this member and the results are shown graphically in figure 29. The rocks of this member in the Crested Butte field constitute Eldridge's "productive measures of the Laramie."

The Paonia or coal-bearing member of the Mesaverde is overlain by a series of thick beds of sandstone that are separated by layers of shale. This series is 1,500 feet or more in thickness in the Crested Butte field and corresponds in lithologic character and stratigraphic position to the undifferentiated part of the Mesaverde in the Grand Mesa field with which it is here correlated. Although it is well exposed in many places (see Pl. XIII, $B$ ), no coal of great importance has been found in it. It constitutes the "unproductive measures" described by Eldridge.

Although the coal-bearing rocks outcrop in steep mountain slopes where the harder layers are prominently exposed (see Pl. XIII, $B$ ), the coal beds and the soft shale associated with them are seldom to be seen. at the outcrop, and where they are seen the exposed thickness of the coal can not always be accepted as representing the undisturbed coal beds. This is due to several causes chief among which are: (1) The rocks in the coal-bearing zone are softer and more easily eroded. than the overlying rocks. This causes the accumulation in the coalbearing zone of talus from the cliffs above. (See Pl. XIII, B.) (2) Because of the high altitude of this field, the winter snowfall is heavy, and snowslides from the mountain slopes tend to lodge on the gentler slopes in the coal-bearing zone. When the snow melts, the slopes are left covered with débris. This is strikingly illustrated in Baxter Basin (see Pl. XIV, A, p. 194), where at the time of investigation large areas in the coal zone were found covered to an unknown depth with snow in which were embedded large quantities of rock, brush, and trees that had been torn loose by the snowslides. The heary precipitation at the high altitudes that obtain in the Crested Butte field further tends to obscure the outcrops of the coal by producing dense growths of vegetation; which in turn not only hastens the disintegration of the rocks but tends to hold the soil in 


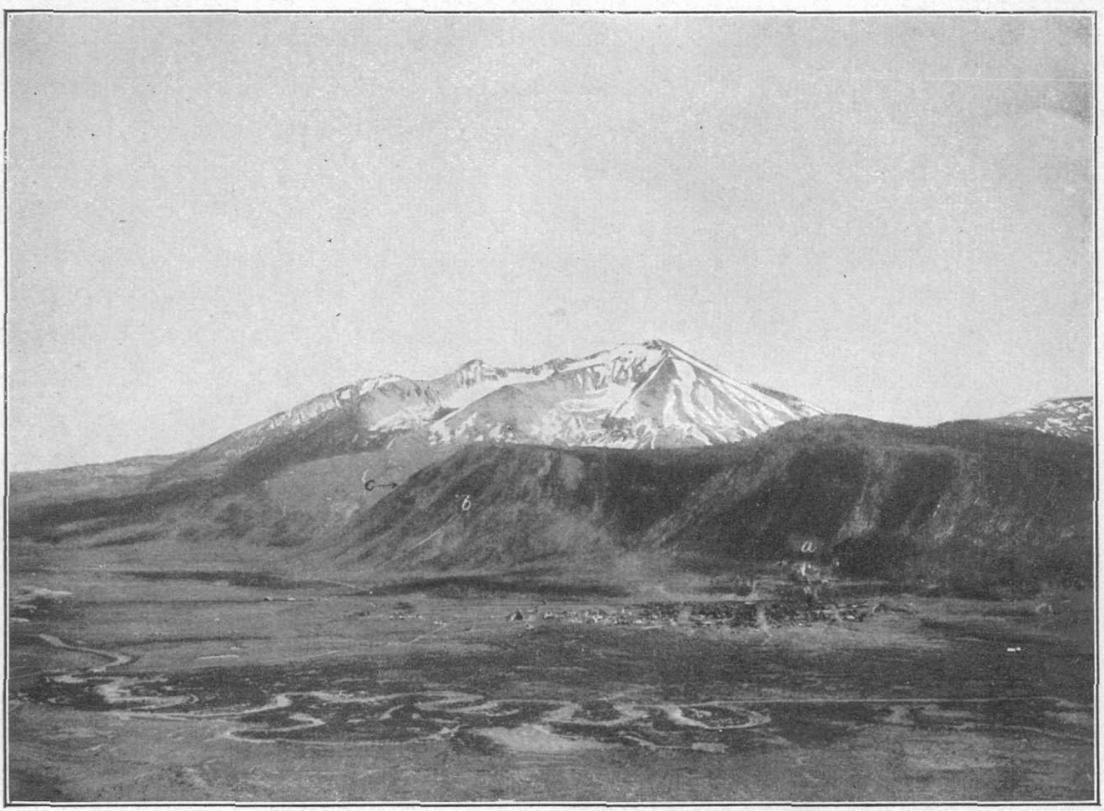

A. CRESTED BUTTE, GIBSON RIDGE, AND MOUNT WHEATSTONE.

The Crested Butte mine is located at $a$, the Porter mine at $b$, and the Bulkley mine at $c$. Mount Wheatstone (altitude, 12,543 feet), is a mass of porphyry intruded near the base of the coal measures. The coal beds are upturned upon its flank. (Photograph taken June 20, 1909.)

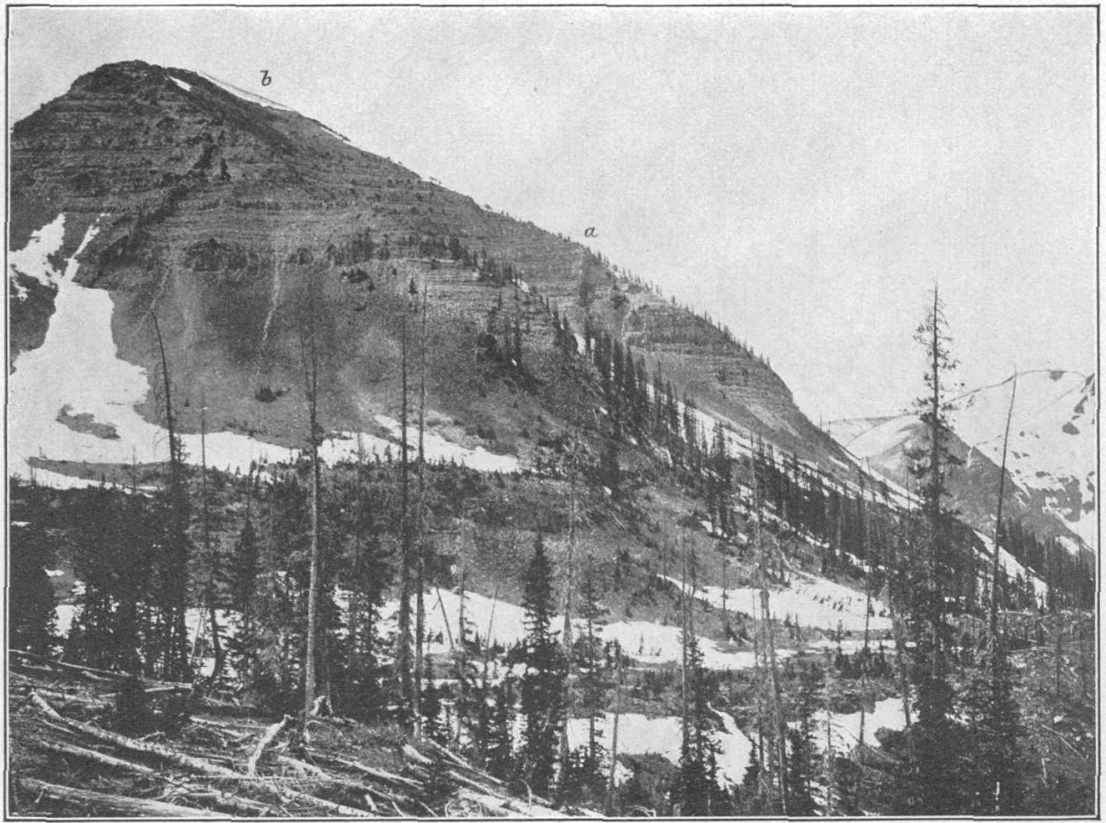

B. SCHUYLKILL MOUNTAIN, NEAR HEAD OF SLATE RIVER.

The outcrops of the coal beds are covered by the talus slopes shown in the foreground. The mountain consists. of the unproductive measures overlying the coal. Faulting has occurred at the points marked $a$ and $b$. 


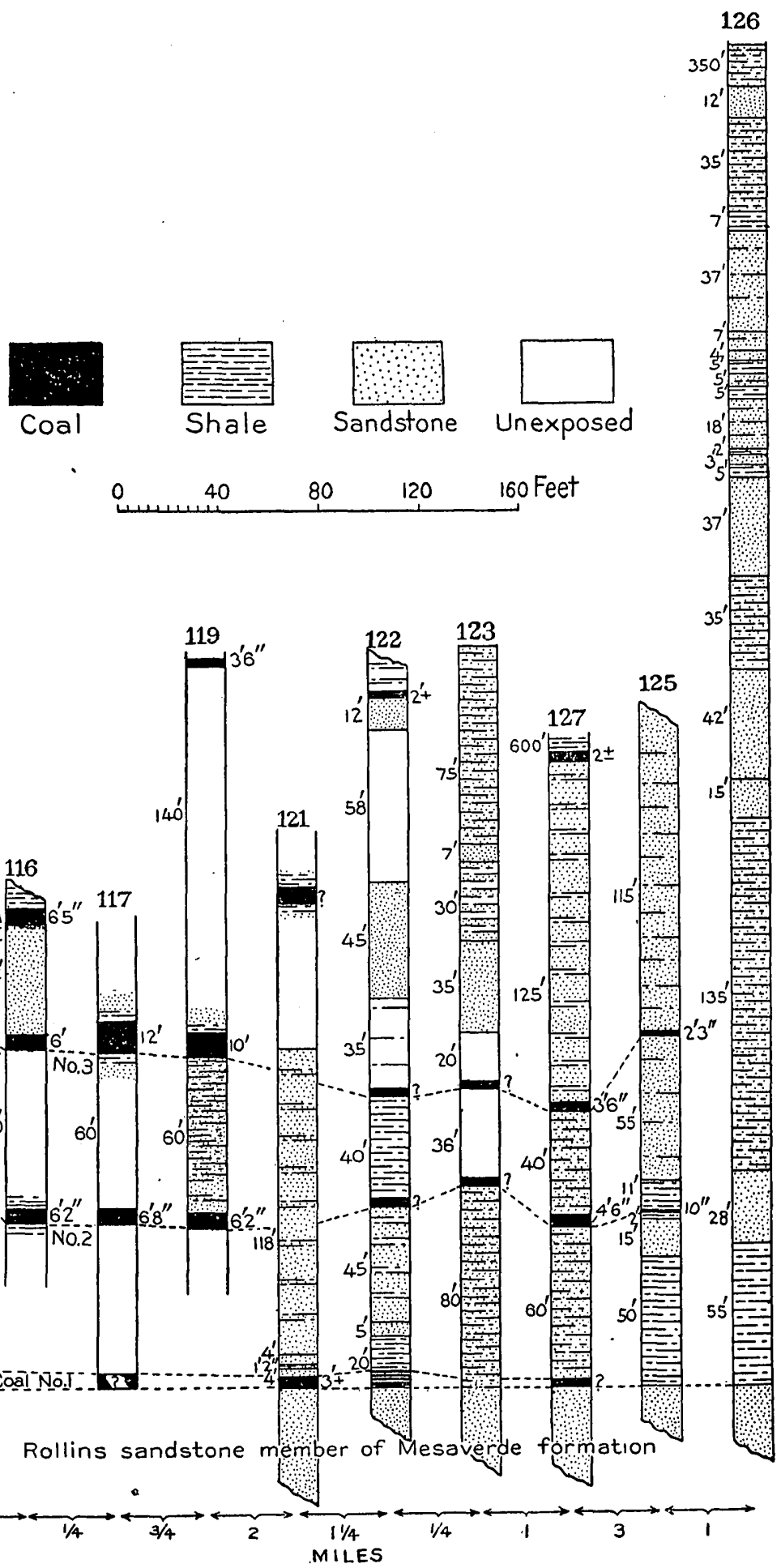

FIGURE 29.-Columnar sections of coal-bearing rocks measured in the Crested Butte coal field. 
place. The shale near the coal beds is readily disintegrated, and in many places the coal-bearing zone is occupied by smooth, soilcovered slopes, in which not even the hard sandstones outcrop. On the steep slopes there is always a tendency for the rocks at the surface to work downward by what is technically known as a surface creep. In many places this creep has developed into "slumps" in which large masses of surface rock have moved downward for considerable distances. In still other places the downward movement has loosened large quantities of rock and caused landslides.

No place was found in the Crested Butte field where the rocks are - exposed well enough to determine satisfactorily the number and thickness of all of the coal beds. The most satisfactory geologic section of the coal-bearing rocks found in this field was measured in Baxter Gulch, at locality No. 115, where three beds of coal are well exposed, but even here there are indications that a bed of coal may occur between coal beds No. 1 and No. 2 of the section (see fig. 29, p. 171), but no undisturbed coal was found in it. The coal of bed No. 4 of this section was crushed by the surface movement of the rocks and the thickness of the undisturbed bed could not be ascertained. A still higher coal horizon is reported by Eldridge in his Baxter Gulch section given in Geologic Folio No. 9, but this was not found during the present investigation.

An attempt has been made in figure 29, page 171, to correlate with the coal beds of this section those found in other localities, but definite correlation has not been found possible, as will be shown in the following descriptions of localities. In several places a bed of coal was found resting either upon the Rollins sandstone or separated from it by a few feet of shale. This bed has been termed coal No. 1 of the Crested Butte field. It is possible that it is to be correlated directly with coal bed No. 1 of the Mount Carbon field. The coal-bearing rocks are continuous between the two fields west of Mount Wheatstone, and coal No. 1 of the Mount Carbon field is exposed about five miles south of locality No. 113, the point nearest to the Mount Carbon field, at which No. 1 coal of the Crested Butte field is exposed. However, as has just been stated, it is not certain that any rocks of Bowie age occur in the Crested Butte field, and coal No. 1 of this field may be the lowest bed of the Paonia member of the Mesaverde formation corresponding to coal No. 2 of the Mount Carbon field, which at locality No. 110 , about 3 miles southeast of locality No. 113, rests upon the basal or Rollins sandstone.

Coal bed No. 1 of the Crested Butte field was not found in all parts of this field. In the southeastern part it is a commercially important bed with a maximum thickness of 6 feet 8 inches of coal. (See fig. 30, p. 173.) It thins toward the northwest, being too thin to work at locality No. 122, and at locality No. 123 it was not found. In 
Anthracite Mesa, locality No. 127, the bed is represented by shale in which are thin seams of coal, but farther northwest in this mesa the coal of this bed attains a maximum observed thickness of 2 feet. In upper Slate River valley no coal was observed at this horizon.

Coal bed No. 2 (see fig. 29, p. 171) apparently is persistent throughout the Crested Butte field. It is not certain that the correlations indicated on this plate of sections are correct, as will be shown in the following descriptions of details, but they are in harmony with the most accurate information obtainable at the present time. The coal has been well prospected in the southeastern part of the field and ranges in thickness from 4 feet 11 inches to 6 feet 8 inches. (See fig. 31, below.) At locality No. 119 the coal has been extensively mined in the lower workings, now abandoned, of the Crested Butte mine. In Anthracite Mesa it has been developed to some extent in the lower workings of the Anthracite mine. (Seefig. 36, p. 198.) The bed occurs

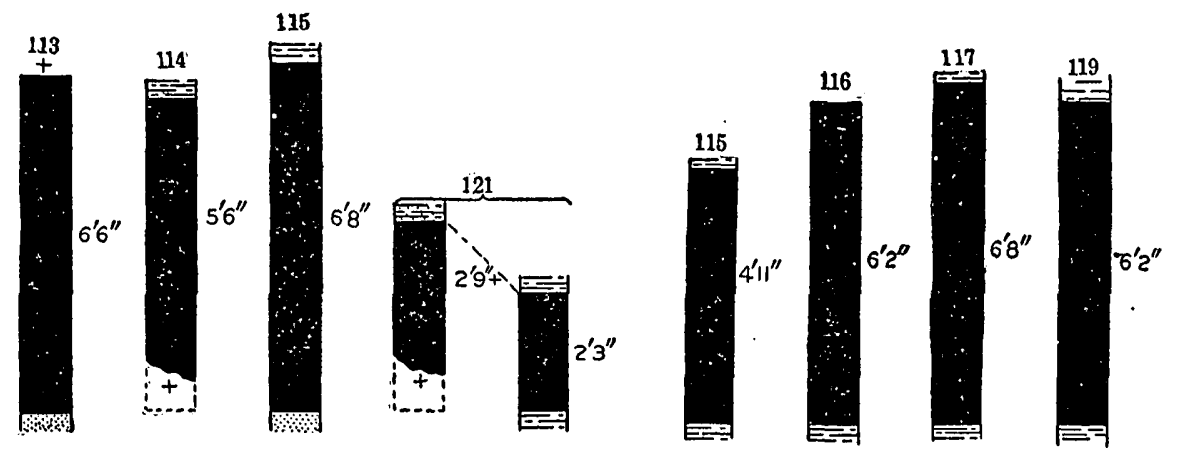

FIGURE 30.-Sections of coal measured in coal bed No. 1 of the Crested Butte coal field.

Figure 31.-Sections of coal measured in coal bed No. 2 of the Crested Butte field.

in the south wall of Slate River valley and in Oh-be-Joyful Gulch, but no satisfactory measurements of its thickness were obtained west of Crested Butte. Southeast of this town the bed contains coking bituminous coal but northwest of it the coal is anthracite.

Coal bed No. 3 also is persistent throughout the Crested Butte field and is the most important and most extensively developed bed of this field. It is variable in thickness, but this variation is largely due to the mechanical thickening and thinning of the coal caused by rock movements. In the Bulkley mine, locality No. 116, the coal has been crushed and otherwise disturbed to such an extent that a mine opened in it has been abandoned. In the Porter mine, locality No. 117 (see fig. 32 , p. 177), the bed has been but little disturbed, but in the Crested Butte mine (see fig. 33, p. 184) the coal has been so much disturbed and the original thickness of the bed so changed by rock movements that the coal varies in thickness from a few inches to 22 feet. In Anthracite Mesa this coal has been developed in the upper workings 
of the Anthracite mine. The thickness of the coal varies in this mine also, but as a rule it appears to be 4 to 7 feet thick. Some if not all of the prospects opened in the side of Anthracite Mesa are in this bed (see fig. 35, p. 196) and show the presence of a thick bed of coal. Nevertheless in actual mining this coal was found to be crushed in so many places in Anthracite Mesa that the mine was abandoned.

Coal bed No. 3 apparently is persistent in upper Slate River valley and in Oh-be-Joyful Gulch but few exposures of it could be found. Like coal No. 2 this bed contains anthracite coal northwest of the town of Crested Butte and coking bituminous coal southeast of this town.

There are coal beds higher than coal No. 3 in the Crested Butte field, but little can be said of them at this time. Their positions in the measured sections are shown in figure 29 , page 171 , and what little is known of them is contained in the following descriptions of localities. If the beds are as persistent and regular as coals No. 2 and No. 3 , there must be at least two coal beds above coal bed No. 3. (See fig. 29.) On the other hand, it is possible that the highest beds shown in sections Nos. 119, 122, and 127 are parts of coal bed No. 4 and that their high positions in the sections are due to faulting. The only place in which this highest coal has been exploited is at the Bulkley mine, locality No. 116, where a mine opening was made in it during the summer of 1909, but it was opened near the Crested Butte mine, locality No. 119, and in Coal Creek canyon several years ago.

\section{DESCRIPTIONS OF LOCALITIES.}

Locality No. 113.-At locality No. 113, in.sec. 14, T. 14 S., R. 86 $\mathrm{W}$., of the projected land net, there is an old mine now abandoned that had been worked five years previous to the time of investigation and the entry was accessible for a distance of 125 feet from the mouth. The bed is something more than 6 feet 6 inches thick but the top of the coal was not seen.

A sample of coal was taken for analysis from a freshly cleared face 125 feet from the mouth of the entry and includes the lower 6 feet 6 inches of the coal. The results of the analysis are given as No. 7977 of the table of analyses on page 207.

The coal is bed No. 1 of the Crested Butte field or the first above the Rollins sandstone, which constitutes the floor of the old mine. The sedimentary beds are sharply upturned against the igneous rock of the Wheatstone laccolith a few hundred feet south of this mine, but the outcrop west of this locality near the contact of the igneous and sedimentary rocks is covered with slide rock and no coal was seen for a distance of nearly a mile.

Locality No. 114.- On the north slope of Mount Wheatstone at an altitude of 10,300 feet, in sec. 15 , T. 14 S., R. 86 W., of the projected 
land net, at locality No. 114, the coal-bearing rocks are steeply upturned against the igneous mass of the Wheatstone laccolith (strike N. $70^{\circ} \mathrm{E} ., \operatorname{dip} 41^{\circ} \mathrm{N}$.). Three old prospects were found here on the same bed of coal. They were inaccessible at the time of investigation, but one of them was partly reopened and 5 feet 6 inches of good bituminous coal was found in it under a cover of shale. Nothing was found that definitely fixed the stratigraphic position of the bed.

The coal is bright and clean and although it is close to the igneous rock, it is no more metamorphosed than coal at localities considerably farther from the laccolith.

Farther west the surface is covered with slide rock and brush, and no exposures were found along the contact of the sedimentaries with the igneous rock of the Wheatstone laccolith. The presence of the Ohio Creek conglomerate a short distance west, a formation which lies stratigraphically some 2,000 feet above the base of the coal-bearing rocks, indicates that the igneous rock here may have broken through the coal beds instead of upturning them as it did at localities No. 113 and No. 114.

Between these two localities and Baxter Gulch the surface rock consists of fragmental material from Mount Wheatstone, possibly of glacial origin, but the Rollins sandstone is exposed at short intervals north and west from locality No. 113 to Baxter Gulch, where a geologic section was measured.

Locality No. 115.-In the north wall of Baxter Gulch the Mancos shale and the Rollins sandstone are well exposed as are also some parts of the overlying coal-bearing rocks. Eldridge in Geologic Folio No. 9 gives a short geologic section of rocks measured in this gulch, in which he shows the lowest coal bed 5 feet thick and two thin beds lying 150 and 210 feet, respectively, above the lowest coal. Apparently his section was measured near the forks of the gulch, where an old prospect now inaccessible was found at the horizon of the lowest coal bed. About one-eighth of a mile east of the old prospect, at locality No. 115 , in sec. 11, T. 14 S., R. 86 W., of the projected land net, three coal beds were exposed in recently opened prospects, and the positions of two more beds were indicated by coal "blossom." At this point the following section of the rocks was measured. 
Section of rocks exposed in Baxter Gulch, south of Crested Butte, Colo.

[For graphic section see fig. 29, No. 115, p. 171.]

Sandstone and shale; not well exposed. Indications of coal near base (bed No. 4). (Several hundred feet.)

Sandstone, yellow, massive, contains impressions of deciduous leaves. The base is irregular and has various markings,

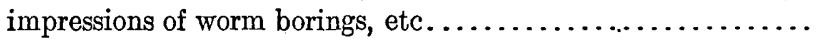

Shale............................................

Coal, clean, firm, bituminous (bed No. 3)...............

Sandstone and shale in alternating layers; not continuously exposed....................................... 20

Sandstone, yellow, massive...................... 30

Coal, clean, firm, bituminous (bed No. 2)............. 411

Not exposed....................................... 15

Coal "blossom," but no coal bed exposed.

Not continuously exposed; apparently shale and shaly sandstone. 60

Coal, with shale roof and sandstone floor (bed No. 1)........ Ft. in. 25

Base of coal measures.

Sandstone (Rollins), massive, cliff making; contains Halymenites major Lesq ......................................

Shale (Mancos).

Only the lowest of the four coal beds of this section or coal No. 1 is shown in Eldridge's section. The lower of his two thin beds may be coal bed No. 4, which is about 167 feet above the lowest coal, but no indication of his highest bed was found. It probably outcrops in the covered slope above the highest sandstone measured in the section. Although no measurement could be made on bed No. 4, the amount of crushed coal at the surface indicates that this bed is relatively thick. Nothing is known of the bed between No. 1 and No. 2 and the "blossom" may possibly be from some thin bed of little value or it may be derived as slide from one of the higher beds.

Locality No. 116.-The Bulkley mine is situated in the side of Gibson Ridge, southeast of Crested Butte, at an altitude of 9,735 feet, in sec. 11, T. 14 S., R. 86 W., of the projected land net, at locality No. 116. Three beds of coal have been opened at this place. The highest one is 6 feet 5 inches thick with shale above and sandstone below. A mine was being opened in this bed during the time of investigation.

Little is known of this bed for it was not certainly identified at any other locality. The next lower coal is the one in which the old workings of the Bulkley mine are situated. It is separated from the highest bed by. 42 feet of rocks consisting mainly of sandstone. The lowest coal bed opened at this locality is 60 feet lower in the section or 102 feet below the highest developed bed, and the coal is 6 feet 2 inches thick with shale above and below it. The material 
between the latter two beds is covered at the outcrop and no exposure of the undisturbed rocks was found. .

The base of the coal measures is not exposed near the Bulkley mine, but apparently the lowest bed opened is too high to be correlated with coal No. 1 of the Baxter Gulch section. The highest two beds at each locality are separated by massive sandstone, and the correlation thus suggested is strengthened by the altitude of the beds at the outcrop. If this disposition of the three coal beds. opened at the Bulkley mine be accepted, then they are beds Nos. 2, 3 , and 4 of the Baxter Gulch section. (See fig. 29, p. 171.) But this correlation must be regarded as provisional until more definite information is obtained.

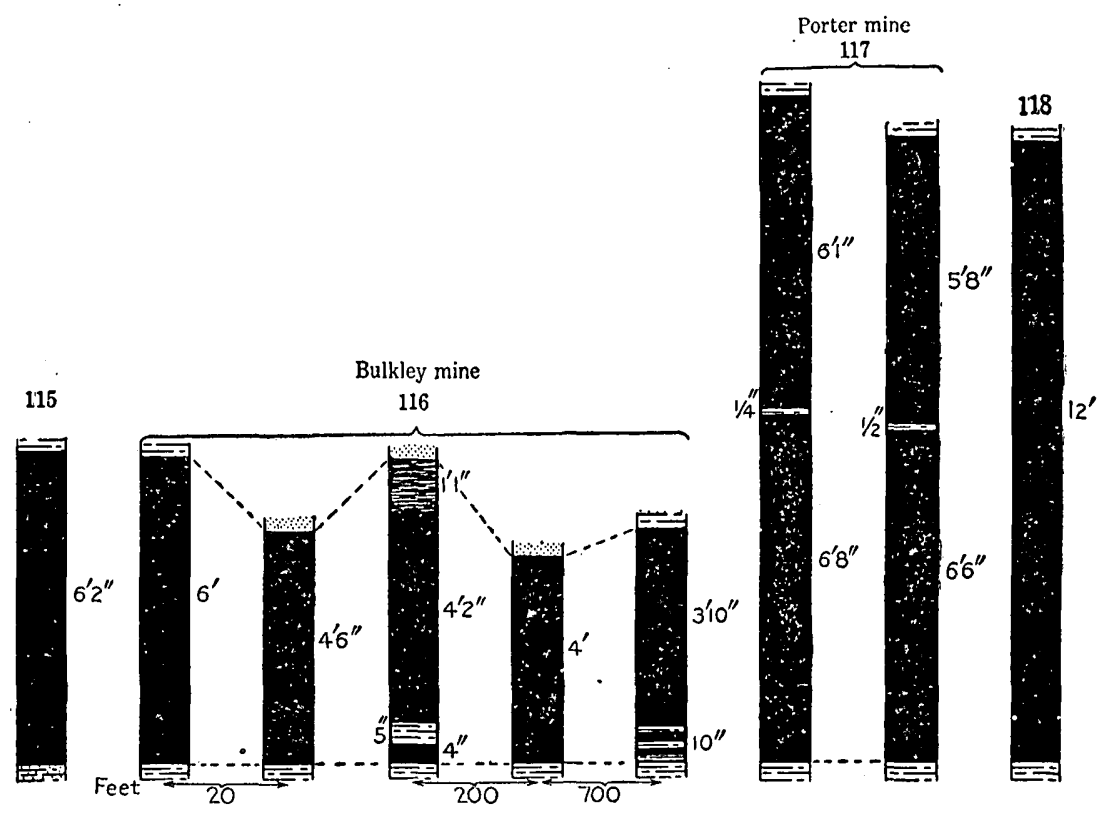

FIGURE 32.-Sections of coal measured in coal bed No. 3 of the Crested Butte coal field.

The middle bed where developed in the old Bulkley mine shows considerable disturbance. Several faults with slight displacement were encountered, and at one of them, which trends N. $63^{\circ}$ E., the beds on the southeast side have dropped 10 feet. The coal in the mine varies greatly in thickness, and in several places the bed shows evidence of lateral movement. The coal is crushed, the laminæ contorted, and the cleat faces warped. Where shale forms the roof it is full of slips and slickensided faces apparently produced by lateral thrust. Five sections of the coal bed were measured in the mine at places selected with a view to showing the general character of the bed. The results are shown graphically in figure 32. Some of the irregularities in thickness and character may be due to surface creep of the rocks, but most of them are believed to be caused by $40642^{\circ}-$ Bull. $510-12-12$ 
readjustments of position in the rocks made necessary by the great igneous intrusions of this region.

The coal of both beds mined at this locality is a clean variety of coking bituminous, and although it is bony in some places the bone can be separated from it in the process of mining. But the irregularities due to faulting and crushing are so great that mining operations had been suspended in the old mine in coal bed No. 3 and development was being pushed on the highest coal at the time of investigation. Preparations were being made, also, to develop the coal below the old mine in bed No. 2 .

Section of coal beds measured at the Bulkley mine, locality No. 116, sec. 11, T. 14 S., R. $86 \mathrm{~W}$.

Shale.

Coal (analysis No. 9139, p. 207) .................... $6 \quad 5$

Sandstone and shale............................... 42

Coal (analysis No. 7980, p. 207).................... $6 \pm$

Sandstone and shale, not well exposed.................6 60

Shale.

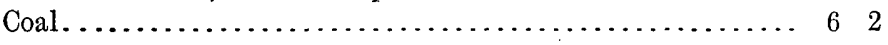

1207

The general dip of the beds at this locality is $6^{\circ}$ due west. The cleat faces where they are not disturbed by thrust trend N. $65^{\circ} \mathrm{E}$. and are of irregular occurrence. The distance between the major joints varies from a few inches to a few feet. In most places the coal is massive and has no partings. The floor of the mine consists of soft clay shale that heaves badly. The wall material whether coal or shale also creeps slowly inward in some places tending to close the mine entries. This is due in part to the pressure of the overlying rocks, but it is possible that the-lateral thrust, which crushed some of the coal, slicken-sided the shale, and threw the bed into a series of wavelike undulations, may still be operative.

Two samples of coal were taken for analysis from the Bulkley mine-one from the newly developed mine in coal bed No. 4 and one from the old mine in coal bed No. 3. Sample No. 9139 was taken from a working face 100 feet from the mouth of the mine and includes 6 feet 5 inches of clean coal. No. 7980 was taken in the old mine, in the part known as the second cross entry off the Gunnison main entry. At this point the following section was measured:

Section of coal bed No. 3 in the old Bulkley mine.

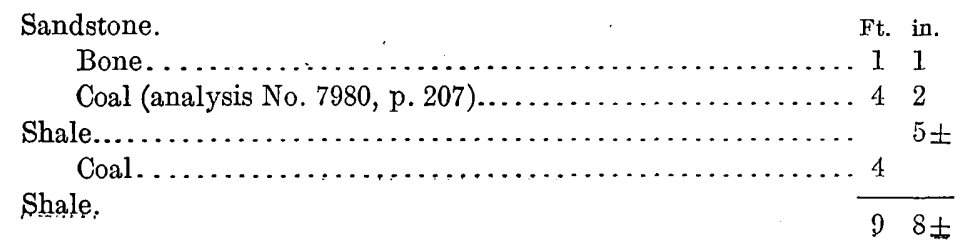


The sample includes only the coal of the upper bench and was taken from a fresh working face. The results of these analyses are given on page 207.

From this mine, which is about 800 feet above the railway, the coal is lowered over a gravity incline to a tipple situated on a side track, where it is loaded directly into the railway cars for shipment. It is used mainly in railway locomotives.

Locality No. 117.- The next place toward the northwest at which coalwas seen is in the Porter mine, which is situated about a quarter of a mile from the Bulkley mine and about half a mile southeast of the town of Crested Butte, at locality No. 117, in sec. 11, T. 14 S., R. $86 \mathrm{~W}$., of the projected land net. The mine opening is in the side of Gibson Ridge at an altitude of 9,525 feet or about 565 feet above the Crested Butte railway, with which it is connected by a gravity incline. This mine is supposed to be operating in coal No. 3 , in which the old Bulkley mine is situated, and the occurrence of a coal bed 60 feet below the Porter mine strengthens the supposition. The correlation of these beds with those of the lowest two opened at the Bulkley mine and with beds No. 2 and No. 3 of the Baxter Gulch section (see fig. 29, p. 171) is confirmed by the statement of the mine superintendent that a bed of coal occurs below the lowest opening at the Porter mine. An opening is said to have been made in this lowest coal several years ago, but this was not accessible at the time of investigation and nothing further was learned concerning it. The known occurrence of four coal beds (perhaps five) so close together as those shown in the Baxter Gulch section renders correlation doubtful, and it is possible that the two beds opened at the Porter mine may be the highest two or Nos. 3 and 4 , of this section.

Where shale forms the mine roof it contains numerous impressions of leaves, conspicuous among which are palm and fig leaves of varieties . apparently identical with those found at localities No.110 and No. 120 and at many places in the Paonia member of the Mesaverde throughout the Grand Mesa field. The coal bed is overlain by a massive sandstone, which in some places rests upon the coal and in other places is separated from it by shale. The coal is black, bituminous, of dull resinous luster and seamy texture. This texture is due to an alternation of thin layers of coal of bright vitreous luster with layers of dull lusterless coal and with layers of charcoal. It is a coking coal, does not slack on exposure to the weather, and has not been known to take fire in the dump. It is shipped without notable deterioration.

The coal is not so badly affected in this mine by rock movements as it is in the Bulkley mine, and only one fault-a normal fault with a displacement of 12 feet-has been encountered. But lateral movement has taken place to some extent as shown by contorted laminæ, 
warped cleat faces, and crushed coal. A thin shale parting in the coal has served as a shearing plane along which movement has taken place, and the coal, about a foot thick below this parting, is more or less crushed and in some places it is ground to fine powder. This parting may have served to relieve without much deformation of the coal the lateral stresses which have notably changed the character of the coal bed in the Bulkley mine and in the Crested Butte mine.

The coal bed in the Porter mine is 12 to 15 feet thick and is regular in character throughout the developed area. Two sections of coal were measured in different parts of the mine and are shown graphically in figure 32 , page 177 ; these adequately represent the character of the bed in the part of the mine that was accessible at the time of investigation. The superintendent states that the thickness and general character of the bed is uniform throughout the workings. Aside from the thin shale parting, no bedded impurities have been found in the coal. The cleat faces are not well developed, but where they occur they trend N. $50^{\circ} \mathrm{E}$. In some places, especially where the coal is more or less fractured, the faces are warped.

Sections of coal bed in the Porter mine, sec. 11, T. 14 S., R. 86 W.

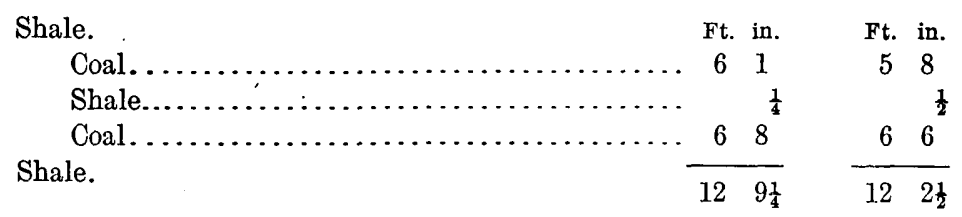

A sample of coal was taken for analysis from a working face in the mine in room No. 2 of the second south entry, where the first section above was measured. It includes both benches or a total thickness, of 12 feet 9 inches of coal. The results of the analysis are given as No. 7981 of the table of analyses on page 207 .

The floor of the mine consists of 6 inches of shale underlain by sandstone. The shale is firm and shows no tendency to creep or heave.

The entrance to the mine is by double drift entry driven in on the coal, and the general system of mining is room-and-pillar. The entries and gangway are timbered with props and crossbars, and the rooms, which are 26 by 200 feet, are timbered with props and caps. The pillars are drawn by the retreating method and the abandoned workings are closed by the settling of the roof.

The mine is ventilated by an 8-foot exhaust fan. Little gas has been detected in the workings, but there is some dust. The mine is sprinkled when it becomes dry, and no dust explosions have occurred. It is drained by means of a pump placed in the lowest part of the workings and operated by steam from boilers placed outside of the mine. 
The coal is sheared at the side by hand and shot down with black powder. Cars loaded with coal are hauled by mules to the main entry and lowered by a rope to the mouth of the mine, where the coal passes over a bar screen, which separates it into lump (about 70 per cent) and slack (30 per cent). The coal is then lowered over a gravity incline to the railway at the foot of the slope, where it is loaded directly into railway cars for shipment. No storage bins are provided and no cleaning is regarded as necessary. The coal is used principally for making steam in both locomotive and stationary engines and to a minor extent as a blacksmithing coal, for which purpose it is only moderately successful. Tests in the coke ovens at Crested Butte have proved that it is a good coking coal. According to the published reports of the Inspector of Mines for Colorado, this mine has been shipping coal since 1905, the yearly output ranging from 11,585 tons to 41,901 tons.

$\mathrm{A}$ coal bed 60 feet below the Porter mine has been opened and a prospect entry driven in on it about 50 feet. In this entry a thickness of 6 feet 8 inches of coal was found with shale roof and shale floor. No mining operations have been carried on in this opening.

Locality No. 118.--In sec. 3, T. 14 S., R. 86 W., between the Porter mine and the Crested Butte mine, at locality No. 118, an opening now inaccessible was made years ago, in which a thickness of 12 feet of coal is reported. The bed is possibly the same as that in which the Porter mine is located, and the same thickness of coal at both localities strengthens the correlation. On the other hand, this is supposed to be the upper bed worked at the Crested Butte mine, locality No. 119 , which in turn is supposed by some to correspond to the lower coal at the Porter mine or bed No. 2. The mountain side in this vicinity is covered with soil and brush, and the beds can not be followed at the outcrop.

A coal bed 140 feet higher than coal No. 3 of this bulletin is reported by Eldridge as 3 feet 6 inches thick. Mr. Frank Young, a mining engineer, who was stationed at Crested Butte at the time Eldridge was engaged in his investigation of this field, states that the measurement given by Eldridge was obtained near locality No. 118. $\mathrm{He}$ also states that this bed was opened in Coal Creek west of Crested Butte, where it contains only 1 foot of coal.

Locality No.119.-The Crested Butte mine is situated at the town of Crested Butte, with its opening in the NW. $\frac{1}{4}$ SE. $\frac{1}{4}$ sec. 3, T. 14 S., R. 86 W., at locality No. 119. The mine workings extend over a large part of the south half of this section and the north half of sec. 10. Two coal beds separated by about 60 feet of sandstone and shale have been opened at this locality, but it is not definitely known at what horizons these beds occur, nor can they be definitely correlated with the coals opened a, the Porter and Bulkley mines (localities No. 117 
and No. 116), for they can not be followed at the outcrop. There aresome reasons for believing that the beds are coals No. 1 and No. 2 of the Baxter Gulch section and others for believing that they are coals No. 2 and No. 3 as shown on figure 29, page 171. The basal or Rollins sandstone is exposed in the bank of Coal Creek at the town of Crested Butte, but the relation of the coal beds to it was not satisfactorily determined. It is claimed by some that a coal bed of unknown thickness (No. 1 of the Crested Butte field) occurs below the lowest workings of the Crested Butte mine; others believe that the lower workings of the mine are in coal No. 1. Eldridge has published in Geologic Folio No. 9 a section measured at Crested Butte in which a coal 5 feet thick is shown at the base of the coal measures and another bed 5 feet 6 inches thick at a horizon 40 feet higher. These doubtless are meant to represent the two beds opened in the mine, which are now known to be separated by 60 feet of sandstone and shale. This measurement as well as the kind of rock separating the two beds of coal is known from records of a shaft sunk from the higher to the lower workings in the mine. In the same section Eldridge shows the occurrence of a coal bed 3 feet 6 inches thick 190 feet above the base of the coal measures, which may be the same as coal No. 4 of the Baxter Gulch section, but more probably represents the highest coal bed of Eldridge's Baxter Gulch section and also the highest coal at locality No. 122. (See fig. 29, p. 171.) This bed was not found near Crested Butte during the investigation, and no other information was obtained concerning it than that contained in Eldridge's published section supplemented by the personal statement of Mr. Young quoted in the description of locality No. 118 and by the analysis of the coal which Eldridge, in Folio 9, calls "No. 3 seam of the Crested Butte mine."

The entrance to the upper workings of the Crested Butte mine is situated in the side of Gibson Ridge south of the town of Crested Butte, and the workings extend southward under a cover of rock 2,000 feet or more in thickness. The shale overlying the coal contains impressions of palm leaves of the same species as those found in the old mine at locality No. 120 and in the upper workings of the Silverbrook mine at locality No. 121. The roof of the mine consists of shale overlain by massive sandstone. The shale is more or less sandy and very irregular in character and in thickness. It is crushed, slickensided, and thickened in many places apparently by lateral movements of the rocks and in these places forms a weak and treacherous roof. It is not jointed but contains many slip faces. It falls in some parts of the mine in more or less regular plates and in other parts in irregularly shaped masses. Props and caps are used in timbering where the roof shale is strong, but crossbars are used wherever the roof is weak. The shale slacks and crumbles to some extent when exposed to a current of air. Its contact with the coal 
is irregular, but the coal parts from it readily in the process of mining. It does not yield gas so far as is known and no pyrite bowlders have been found in it. Some rolls have been encountered and slips are numerous.

The coal is a black, relatively hard, high-grade, coking, bituminous, having a searny texture and generally a vitreous luster, although there are thin seams of dull luster and partings of charcoal. It has cubical fracture in some places, but for the most part it breaks out in irregularly shaped blocks. The coal burns readily to a gray ash producing large quantities of tar and gas. It does not adhere to the grate bars and little clinker is formed. Large quantities of it are used for blacksmithing. The coal bed is affected by weathering only a short distance back from the outcrop and does not slack readily on exposure to the weather. The bed has been thrown into a series of wavelike undulations, apparently by lateral thrust, and in many places the coal has been displaced by small faults and slips, but apparently these have had little effect on the quality of the coal. Coal near the faults is not notably different in character from that of the undisturbed beds farther away.

The coal bed in the Crested Butte mine ranges in thickness from a few inches to 22 feet. The general character of the bed is indicated by the sections shown graphically in figure 33, representing parts of the mine from which the coal has been removed. These sections are so chosen that they show the variations of the bed from a commercial standpoint rather than the extremes in thickness. In some places the coal has entirely disappeared, notably in two barren areas each about 300 feet wide and 600 feet long that were encountered in the mine. The absence of coal from these areas is not understood. The bed may have been continuous at one time and the coal squeezed out by rock movements, or the barren areas may be regions in which coal was never deposited. A maximum thickness of 22 feet of coal at no great distance from one of the barren areas renders it probable that the coal once extended continuously over these areas and was squeezed out laterally by rock pressure that for some unknown reason was greater in these places than in others. At one of the points examined in the mine, the thickness of the coal bed diminished from 17 feet to 5 inches, within a horizontal distance of 50 feet. The coal varies in thickness according to its position relative to the undulations of the bed. Wherever observations were made, the coal was found to be thicker than the average on the anticline and thinner than the average in the syncline, as illustrated in figure 34 (p. 185).

Where the coal bed is least disturbed it consists of two benches as indicated below and as shown graphically in the section marked $a$ in figure 33. The other sections in this figure show only the total thickness of coal. 
184 COAL OF GRAND MESA AND WEST ELK MOUNTAINS, COLO.

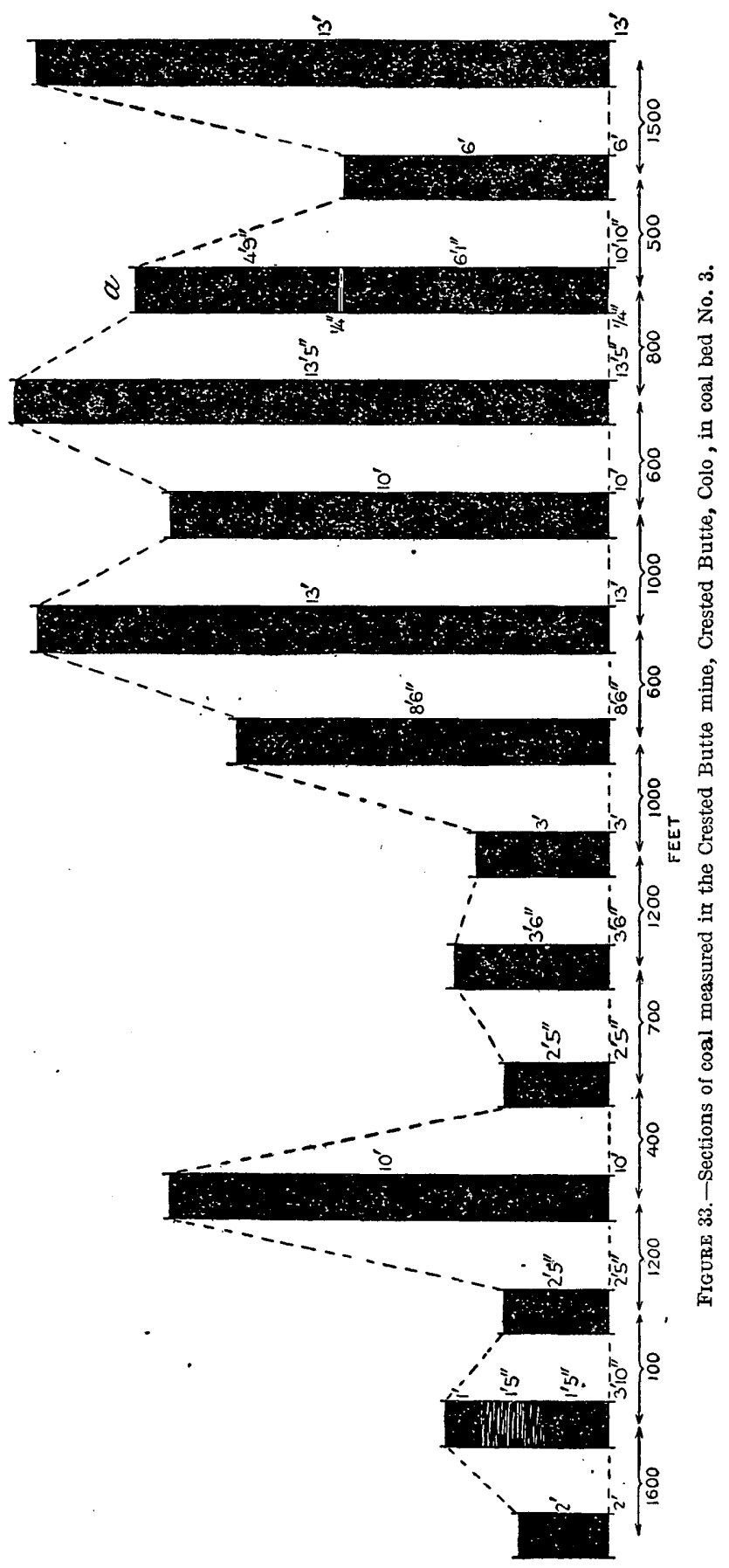


Shale.

Section of coal bed in Crested Butte mine.

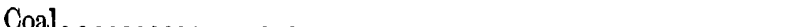

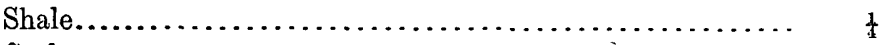

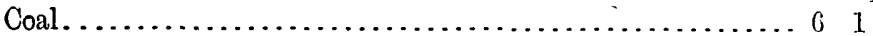

Shale.

The shale parting varies in thickness from a knife-edge in some parts of the mine to several feet in other parts and in places is replaced by sandstone consisting of clean white sand that suggests the filling of an old stream channel. The joint structure of the coal is obscure and in only one place in the part of the mine examined were the cleat faces well enough developed to permit their direction to be measured. The major joints are here 10 to 20 inches apart and trend N. $56^{\circ} \mathrm{E}$.

Two samples of coal were taken for analyses in the Crested Butte mine from the working face in room No. 1 of the fifth cross entry south

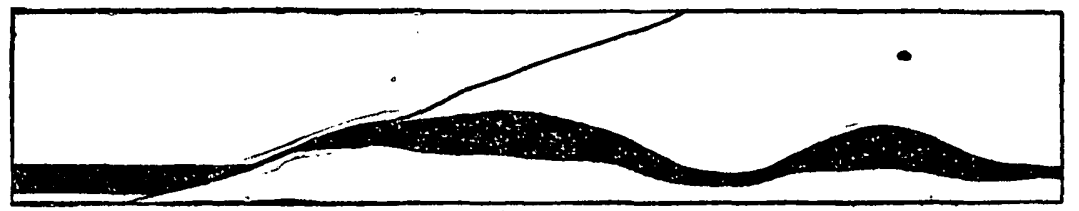

A

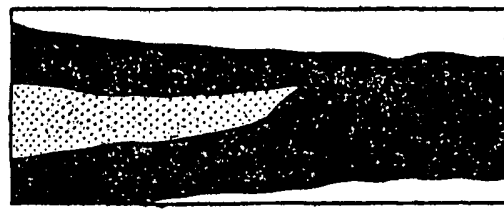

B

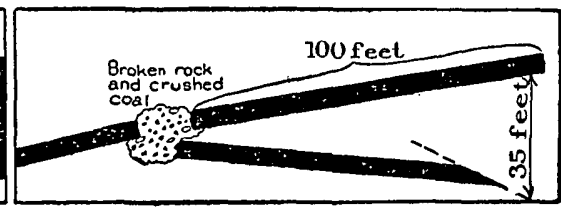

C

FIGURE 34.-Sketch sections illustrating conditions observed in Crested Butte mine. (A) Wavellke undulations of coal bed caused by rock movements and displacement of coal at a slip fault; (B) sandstone wedge thrust laterally into the coal; (C) relation observed in a faulted area of the mine which indicates either the presence of two beds of coal or a duplication of ono bed by overthrust faulting.

of the second incline. No. 7982 includes the coal of the upper bench, 4 feet 11 inches thick where the sample was taken, and No. 7983 includes the 6 feet 1 inch of coal of the lower bench in this room. Also a sample of the weathered coal, No. 8655, was taken at the surface near the mouth of the mine for the purpose of comparing the weathered with the unweathered coal. The results of these analyses are given on page 207. The weathered coal, supposed to be inferior in quality, seems to be superior in some ways to the unweathered coal.

The floor of the mine consists of dark-colored shale of unknown thickness, and although it is generally strong enough for mining purposes some tendency to creep and heave has been observed.

The general dip of the coal bed is toward the southwest (strike $\mathrm{N} .20^{\circ}$ W.), but great variations occur in the direction of the dip and strike due to numerous flexures, faults, and slips. The largest fault 
encountered in the workings trends N. $60^{\circ}$ E. with downthrow toward the southeast.

The entrance to the mine is by double entry drift slopes driven in a southwesterly direction down the dip of the coal bed. The drift extending southward from the opening has been driven along the strike so that it is nearly level. The general plan of mining is by room and pillar. As far as possible the gangways are driven along the strike of the beds in order to avoid steep slopes due to the dip of the rocks, which averages about $10^{\circ}$. In general the rooms are 24 feet wide and 300 to 350 feet long, but they are irregular. The pillars are drawn by the retreating method allowing the roof to settle and close the old workings.

Ventilation is produced by means of a Cappel exhaust fan 11 feet 6 inches in diameter, and the air currents in the mine are directed by brattices. Explosive gases occur at some places in the mine, and the use of safety lamps is enforced by the mine management. No matches or other means of producing an open light are allowed in the workings. The dust of the coal also is very explosive, and the dry workings are sprinkled to prevent explosions, but the natural dampness in the greater part of the mine makes sprinkling unnecessary. The general dip of the coal bed away from the entrance to the mine causes the water to drain inward and to collect at the end of the main slope from which point it is raised by means of a No. 11 Cameron pump.

The coal is sheared at the side by hand and either wedged down or pried off with pinch bars. No shooting is allowed in the mine because of the danger of explosions. Mules are employed underground for gathering the loaded cars, and ropes operated from the mouth of the mine are used for haulage in the main entries. Two hundred wooden mine cars of 3,000 pounds capacity are used, and about 800 tons of coal per day were being produced at the time of investigation.

From the pit mouth the coal is lowered by rope over a gravity incline to the tipple, which is so located that the coal may either be loaded into railway cars or sent to the coke ovens. The tipple is fitted with scales, bar screens, and box-car loader. The slack and some of the lump coal is coked and the remaining lump is shipped for use mainly as a steam coal. The coking plant consists of 154 beehive ovens of 5 tons average capacity situated near the mouth of the mine. Although the coal is neither washed nor picked before going to the ovens, it produces a high-grade coke that is used mainly in smelters and in sugar refineries.

The original opening of the Crested Butte mine was in the higher of the two beds operated. After a mine explosion that occurred in 1884 the workings were closed, and the lower bed was opened and worked until 1894 when the higher bed again was opened and has been productive since that time. 
The openings in the lower bed were.inaccessible at the time of investigation, and all information regarding this coal at the Crested Butte mine was obtained at second hand. The bed contains coking bituminous coal reported to be of about the same thickness and quality as that of the higher bed, but the thickness of the coal is much more regular. Disturbances due to crushing and faulting are relatively slight. The wavelike undulations characteristic of the higher bed and the local thickening and thinning of the coal caused by them do not occur in the lower bed. In short, so far as known, the forces that disturbed the higher bed had little effect on the lower, possibly, as has been supposed, because of the presence of resistant sandstone between the two beds. The writer has no better explanation to offer but will call attention to the fact that for 1,500 feet or more above the coal the rocks consist mainly of sandstone, and it is difficult to understand how a thin sandstone between the two coal beds could protect the lower bed from a force capable of crushing the overlying sandstones. The difference in the character of the beds may be due to some local cause, for it has been observed in an area comprising less than 1 square mile.

The Crested Butte mine is at the critical point where the change in the character of the coal from bituminous to anthracite takes place. Hills ${ }^{1}$ states that "the mine workings are confined to a zone of coking coal less than 1 mile wide, which graduates into semicoking coal on one side and into anthracite on the other." His description refers to the lower workings in Crested Butte mine. A similar variation has been noted in the higher bed. Although the higher coal, so far as it has been developed, is all bituminous, it is said to be notably harder in the part of the mine nearest to the anthracite localities on the northwest than it is in the part farthest from them. These observations are in keeping with the facts observed in the localities described in the following pages where it is shown that the coal northwest of Crested Butte is anthracite.

Locality No. 120.-The basal sandstone underlying the coal measures is exposed at the town of Crested Butte and thence toward the northwest was observed in many places in the sides of Slate River valley. There is an old mine opening at locality No. 120 , in sec. 33 , T. 13 S., R. $86 \mathrm{~W}$., of the projected land net, but it was full of water at the time of investigation and could be examined only near its mouth, where a thickness of 3 feet 3 inches of coal was found with shale floor and shaly sandstone roof. The roof material contains numerous impressions of.leaves of the same species as those found in the Crested Butte mine on the southeast and in the upper workings of the Silverbrook mine on the northwest, and these are in turn identical with those found at many localities farther west in the typical Paonia shale. They are as follows: Geonomites ungeri Lesq., Ficus sp., type of

1 Hills, R. C., Coal fields of Colorado: Mineral Resources U. S. for 1892, U. S. Geol. Survey, 1893, p. 348. 
-F. speciosissima Ward but probably new, and Ficus sp., type of F. planicostata Lesq. but probably new.

The coal is anthracite, but it is not so highly metamorphosed as the coal farther west and north. A comparison of the analyses of this coal (see Nos. 30 and 31, Geologic Folio No. 9) with those of intermediate grades between the anthracite coal from the Silverbrook mine and the coking bituminous coal of the Crested Butte mine indicates that it also holds an intermediate position. The bed is apparently the same as that worked at the highest level in the Silverbrook mine, but it can not be definitely correlated with beds opened at other mines at the present time, because of poor exposures which preclude the tracing of the beds continuously along the outcrop.

Locality No. 121.-A considerable number of openings have been made in the vicinity of the Silverbrook mine near locality No. 121, in sec. 28 , T. 13 S., R. $86 \mathrm{~W}$. Six old prospects were found on the lowest bed or coal No. 1, which occurs a few feet above the Rollins sandstone, but only one of them was accessible. This was partly filled with water, but the upper part of the coal bed near the mouth of the opening was examined and the following section was measured at the outcrop:

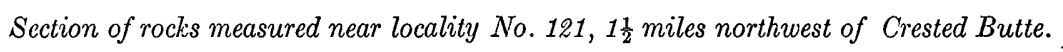

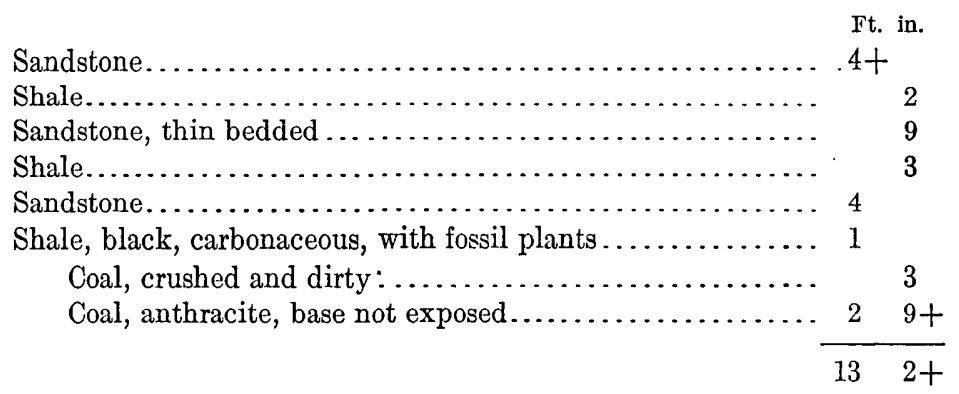

The fossils found above the coal are the remains of plants apparently of the same species as those found associated with the higher coal beds and the same as those found in the Grand Mesa field in the typical Paonia shale. This coal is bed No. 1 of the Crested Butte field, and the fossils are regarded as giving sufficient evidence that this as well as the higher coal bed should be referred to the Paonia or fresh-water member of the Mesaverde and that the Bowie or marine and brackishwater member of that formation is not present at this locality.

At the lower workings of the Silverbrook mine, a shaft has been sunk 118 feet to the lowest coal bed just described. The horizons at which coals No. 2 and No. 3 of the Baxter Gulch section should occur were penetrated by this shaft, but the superintendent of the mine states that no coal was found. From the bottom of the shaft an entry has been driven 300 feet in one direction and 400 feet in the opposite direction. 
Rooms have been turned off from these entries and preparations were being made at the time of investigation to mine coal for the market. So far as development shows, the bed is irregular, ranging in thickness from less than 2 feet to more than 4 feet. At the point where development work was being carried on at the time of investigation and where a sample of the coal was taken for analysis, the coal is 2 feet 3 inches thick with shale above and below it. For analysis of the sample collected in this mine see No. 7978, page 207.

The coal is a hard, bright, massive anthracite, with conchoidal fracture, without lamination or other marks of bedding, and without partings other than the irregular fractures and slickensided faces caused by shearing movements that have taken place within the coal bed. The want of bedding planes or partings, the presence of the slickensided faces, and the variations in thickness of the bed suggest that the stresses produced in the neighboring rocks by the various crustal movements that have affected this field were relieved in some measure by readjustments within the coal bed.

The rocks are not exposed at the outcrop in the interval of 120 feet between the top of the mine shaft and the coal bed developed in the upper workings of the Silverbrook mine. The dips of the beds at this locality are not regular, and the upper workings, although 120 feet above the top of the shaft as measured on the slope, are probably not more than 50 feet stratigraphically above the top of the shaft or about 170 feet above coal bed No. 1. This relationship suggests the correlation of the bed at the upper workings with coal No. 4 of the Baxter Gulch section (see No. 115, fig. 29, p. 171), but this correlation is provisional. The coal bed could not be followed at the outcrop on account of surface covering, and no definite evidence of its exact position in the section was obtained. A bed of carbonaceous shale 100 feet above the upper workings was found with 2 inches of coal, and this bed may represent the coal found at locality No: 122, 260 feet above the base of the coal measures.

The opening to the upper workings was driven through 50 feet of slide rock before the undisturbed coal was reached. This opening is located in sec. 28 , T. 13 S., R. 86 W., of the projected land net, in the south wall of Slate River valley, and is connected with the railway by a gravity incline. The roof shale contains numerous impressions of leaves, conspicuous among which are large palm and fig leaves of the same species as those found in the old opening at locality No. 120 and apparently identical with those found in the typical Paonia shale in the Grand Mesa field. They are as follows: Geonomites ungeri Lesq.; Ficus speciosissima Ward; Ficus sp. type of F. oblanceolata; Pterospermites undulatus? Knowlton.

The coal bed is overlain by shale and shaly sandstone, which is strong and forms a good roof for the mine. The coal is a black, 
relatively hard anthracite, of dull, vitreous luster, seamy texture, and conchoidal fracture. Some slickensided faces were found. Cleat faces are developed in some places, and the lamination due to the presence of lusterless charcoal between layers of the brighter coal is more or less perfectly preserved. On the whole, this coal does not seem to have been disturbed by rock movements to so great an extent as was the lower bed or coal No. 1. Although the coal is an anthracite, it is softer and duller in appearance than the anthracite of the lower bed. Where the coal was examined in the mine it varies in thickness from 2 feet 10 inches to 3 feet 4 inches and is separated into two benches by a thin shale parting, which is persistent but varies in thickness to some extent. The general character of the bed is shown by the following section measured in the second cross entry of the upper workings of the Silverbrook mine.

Section of coal bed in the Silverbrook mine, sec. 28, T. $19 S .$, R. 86 W.

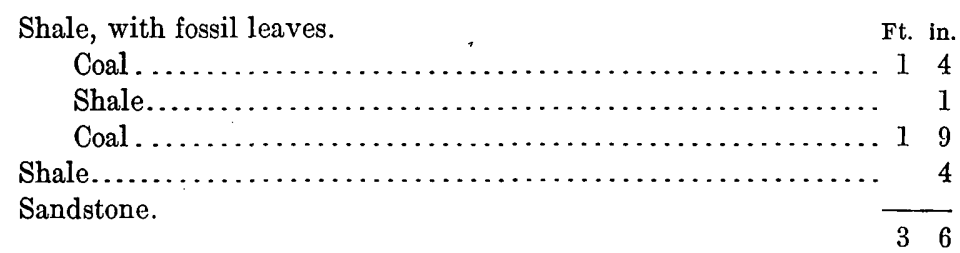

A sample of coal was taken for analysis at the point where this section was measured and includes the coal of both benches, 3 feet 1 inch thick. The results of the analysis are given as No. 7979 of the table of analyses on page 207.

The general plan of mining is by room-and-pillar. The main entry is driven up the rise, and rooms 25 feet wide and 200 feet long are turned off from this entry and are timbered with props and caps. The coal is drilled by hand and shot from the solid with black powder. The mine is damp, but the water flows down the main entry and is discharged at the mouth of the mine.

The coal is crushed in a breaker and is screened to the usual sizes desired for domestic use.

Locality No. 122.--In sec. 29, T. 13 S., R. 86 W., of the projected land net, at locality No. 122, in the south wall of Slate River valley, 500 feet or more of Mancos shale and the Rollins sandstone are well exposed. The overlying coal measures consist of alternating layers of cliff-making sandstone and soft shale. The sandstones are exposed at the outcrop, but the intervening layers of shale are more or less covered with rock débris. Coal was found at four horizons, but the beds could not be traced along their outcrops because of the covering of brush and slide rock, and the coals were so much disturbed by the downward creep of the surface rock that their thicknesses could not be determined without more extensive prospecting than 
was possible at the time of investigation. The following geologic section was measured at this locality:

Section measured in the south wall of Slate River valley, at locality No. 122, 3 miles northwest of Crested Butte.

[For graphic section see fig. 29, No. 122, p. 171.]

Sandstone in thick plates separated by shale, many hundreds of feet.

Coal.

Feet.

2 ?

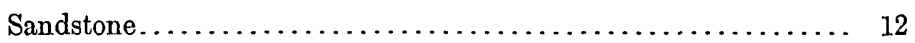

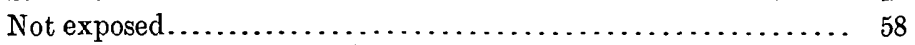

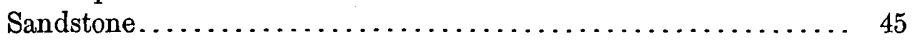

Shale, not continuously exposed ................... 35

Coal, thickness not known (coal bed No. 3).

Shale.

Coal, thickness not known (coal bed No. 2).

Shale, with thin sandstone layers...................... 45

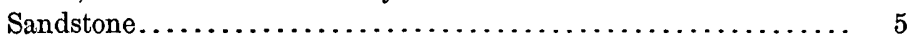

Shale, dark colored, with thin seams of coal at base. Contains conifer, willow, and fig leaves....................... 20

Base of coal measures.

Sandstone (Rollins), gray, massive................. 80

Shale, dark colored.................................. 8

Sandstone and shale in alternating layers. Contains Halymenites major Lesq...................................... 22

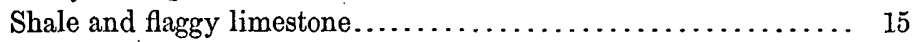

Shale, dark blue, with limestone concretions............... 8

Limestone, sandy, and shale in alternating layers............ 30

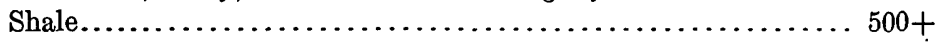

Coal bed No. 1 consists of dark-colored shale with several seams of coal an inch or two in thickness. The two coal beds next higher than No. 1 apparently are coals No. 2 and No. 3 of the Crested Butte field, which have been developed at the localities previously described and at the Anthracite mine on the north, locality No. 127. No place was found where the undisturbed coal could be opened, but the amounts of crushed coal found at the outcrop indicate that coal beds No. 2 and No. 3 are probably not very thick.

A fourth bed of coal was found 260 feet above the base of the coal measures. It was opened at the time of investigation and a thickness of 2 feet of crushed coal was found. The undisturbed bed would doubtless contain coal more than 2 feet thick. This is apparently the same as the highest bed of coal found in the Crested Butte section, No. 119, and also the highest one in the Anthracite Mesa section, No. 127, of figure 29; page 171, but the bed was not found in the other sections measured.

Locality No. 123.-At locality No. 123 , in sec. 20 , T. 13 S., R. 86 W., of the projected land net, anthracite coal was observed at horizons about 80 feet and 116 feet above the top of the Rollins sand- 
stone. The beds have been displaced by surface movements and the thicknesses of the coal were not ascertained. These correspond apparently with coal beds No. 2 and No. 3 of the Crested Butte field, and in view of the known regularity of these beds where they can be identified with reasonable certainty it is probable that they contain coal of considerable importance in this vicinity. The following short section was measured at this locality:

Section in Slate River valley at locality No. 123, south of Anthracite.

[For graphic section see fig. 29, No. 123, p. 171.]

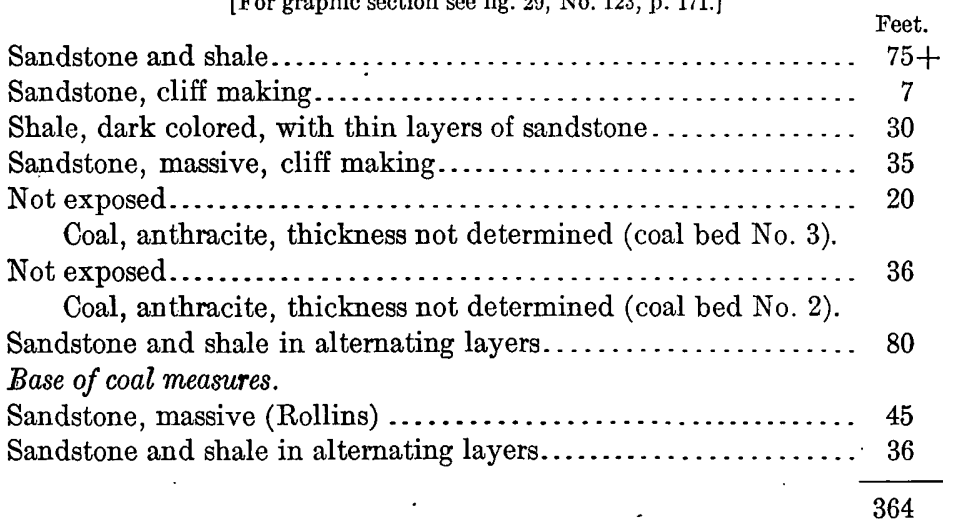

Indications of coal were observed in several places in the walls of Oh-be-Joyful Gulch, but the outcrops of the beds can not be followed continuously, and in no place could measurements of the coal be made or the exact stratigraphic position of any coal bed be determined. This is due largely to the fact that the coal is either disturbed near the outcrop by the downward creep of the rocks at the surface or is entirely covered with slide rock. The coal beds occur in relatively soft rocks locally known as the productive measures. These are eroded more easily than the hard cliff-making sandstones of the overlying unproductive measures. (See Pl. XIII, $B$, p. 170.) The fragmental rock derived from the cliffs tends to lodge on the gentler slopes below in which the coal outcrops and often covers the coal beds with thick accumulations of slide rock. Two coal beds, probably No. 2 and No. 3 of the Crested Butte field, seem to be persistent throughout this field (see fig. 29, p. 171), and these two beds probably occur in Oh-be-Joyful Gulch. It is equally probable that there are many places in this gulch where the beds will be found to be too thin and the coal too dirty for mining, as is the case in Anthracite Mesa described farther on, and there are some places where coal beds were not found, although the rocks are well exposed at the horizons where coal is to be expected. One such place was found at the southeastern extremity of the ridge between Oh-be-Joyful Gulch and Slate River valley, where a section of rocks in the coal-bearing 
zone was found fairly well exposed, but if the coal beds occur there, they fail to give any surface indication of their presence.

Several old prospects were found in Oh-be-Joyful Gulch at the localities indicated by crosses on the map, and coal 2 to 5 feet thick is reported as occurring at these points; but none of the old prospects was accessible at the time of investigation, and no place was found where the coal beds could be opened with any means available. The coal found in these old prospects is reported to be all anthracite.

Locality No. 124.-Conditions similar to those just described obtain in the north slope of the ridge between Oh-be-Joyful Gulch and Slate River, although better exposures of the rocks were found there. No coal was found at the horizon of the lowest coal or bed No. 1, but beds No. 2 and No. 3 were found in some places. From the end of the ridge near the mouth of Oh-be-Joyful Gulch, the outcrop of the "productive measures" was followed toward the northwest and searched for indications of coal. Coal "blossom" was found in the slide rock at several places, but at no place was an undisturbed coal bed found. At locality No. 124 a prospect opening was driven in on a coal bed where the coal seemed to be less disturbed than at other places, and 1 foot 2 inches of anthracite coal was found 12 feet from the surface. The coal was crushed and the undisturbed parts of the bed could not be reached by the means available at the time of investigation.

Locality No. 125.- Some of the rocks of the productive coal measures are exposed at locality No. 125 and a short section was measured there. A coal bed was found 65 feet above the basal sandstone and another bed 139 feet above it. Apparently these are coal beds No. 2 and No. 3 of the Crested Butte field. No indication of the presence of coal No. 1 was found. Attempts were made to open the coal beds; a thickness of 10 inches was found in bed No. 2 and a thickness of 2 feet 3 inches in bed No. 3. The coal in both beds is crushed and doubtless would show greater thickness in both in the undisturbed part beyond the zone affected by slide rock and surface creep.

Section of rocks measured in Slate River valley, south of. Pittsburg, at locality No. 125.

[For graphic section see fig. 29, No. 125, p. 171.]

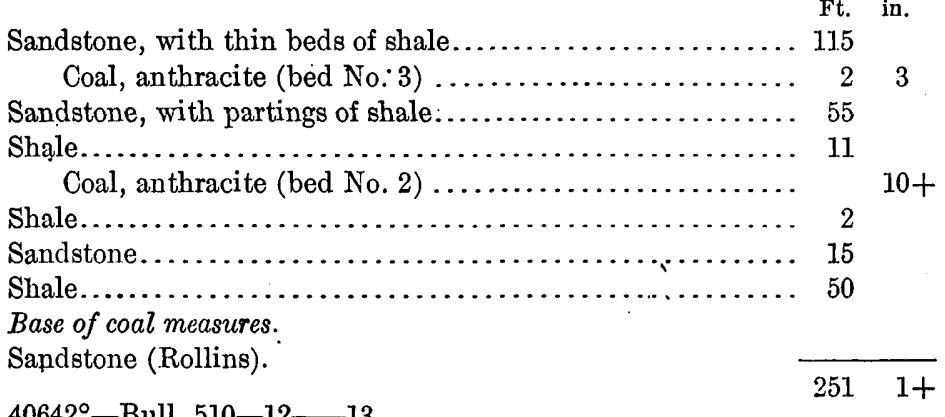


Locality No. 126.-At locality No. 126, about 1 mile southwest of Pittsburg, surface indications of coal were found in the zone of the coal-bearing rocks. The horizons suggested the presence of coals No. 2 and No. 3, but the undisturbed beds were not located and are therefore not shown in the graphic section on figure 29, page 171. At this locality a considerable thickness of the barren series of rocks above the productive measures is well exposed, and a detailed section of the lower part of them was measured. Although a careful search was made for coal, none was found at this place. The section is as follows:

Section of rocks.measured in Slate River valley, near Pittsburg, at locality No. 126.

[For graphic section see fig. 29, No. 126, p. 171.]

Feet.

Sandstone, shaly with thin beds of coal.............. 350

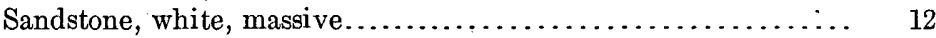

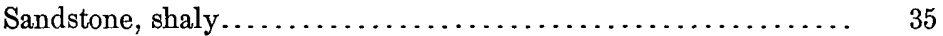

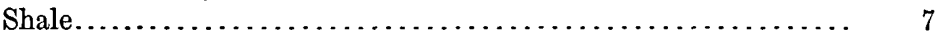

Sandstone, with thin partings of shale................ 37

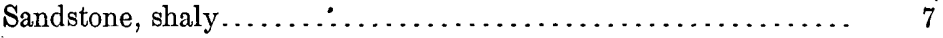

Sandstone................................. 4

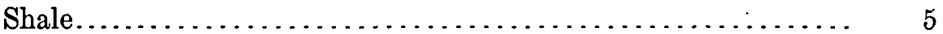

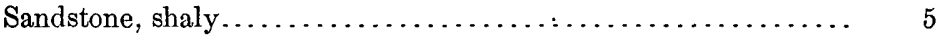

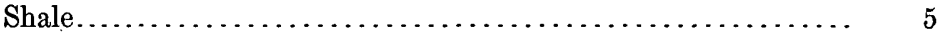

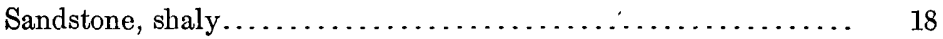

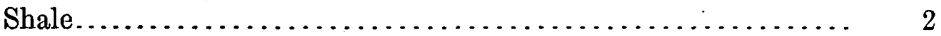

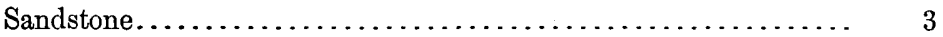

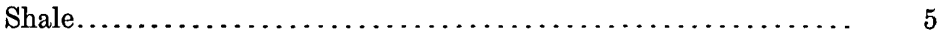

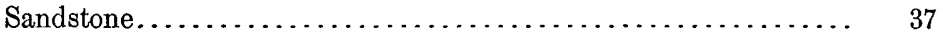

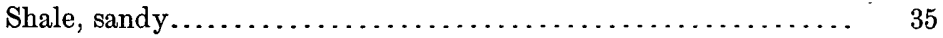

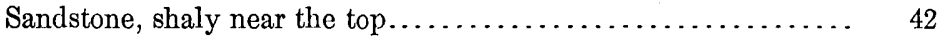

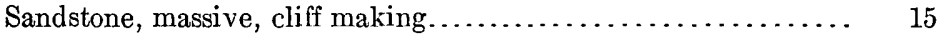

Shale and sandstone, containing coal (not well exposed) ...... 135

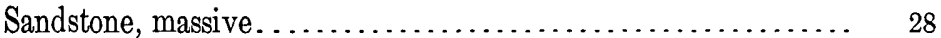

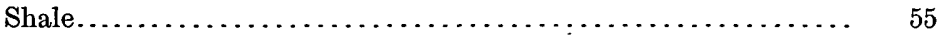

Base of coal measures.

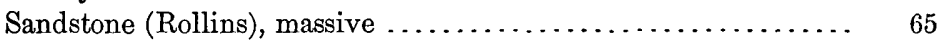

Shale...................................... 900

Intrusive igneous rock. . . . . . . . . . . . . . . . . . . 17

Shale..................................... 300

2,124

No coal was seen in Baxter Basin, and there was little hope at the time of investigation of finding any because of the thick accumulations of snow. (See Pl. XIV, A.) The outcrop of the coal reaches altitudes of more than 11,500 feet, and the rocks are upturned against the intrusive mass of Augusta Mountain. They are fractured, displaced in some places, and intruded by dikes and sills of igneous. rocks.

It is reported that considerable prospecting for coal has been done in this basin by men interested in the metalliferous deposits of 


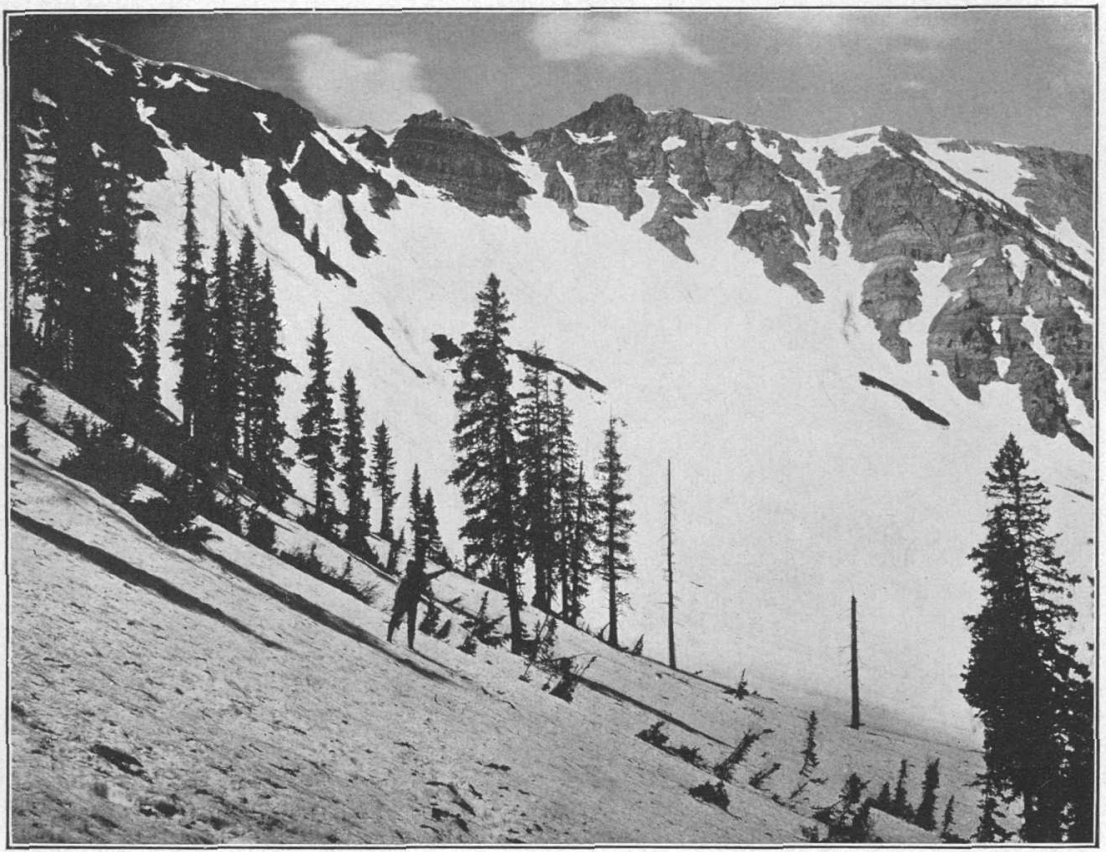

A. BAXTER BASIN NEAR HEAD OF SLATE RIVER.

The coal crops out in the snow-covered slope shown in the foreground. The "barren measures" overlying the coal beds appear in the cliffs. (Photograph taken June 30,1909.)

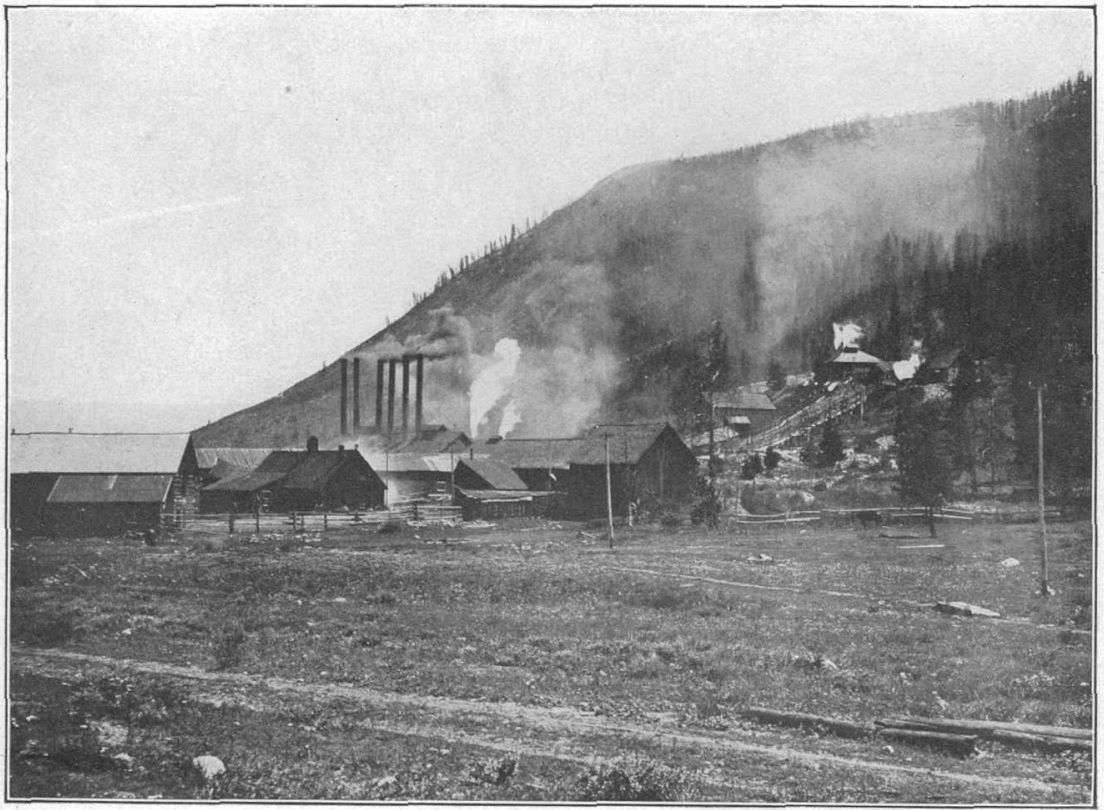

B. THE CRESTED BUTTE MINE. 
the region, and the fact that no coal mining has been undertaken and none of the old prospects has been kept open may be regárded as evidence that the coal beds of Baxter Basin are of doubtful value.

Locality No. 127. - The Anthracite mine is located in sec. 17, T. 13 S., R. 86 W., of the projected land net, at locality No. 127, 4 miles northwest of the town of Crested Butte, with which it is connected by a spur of the Crested Butte Railway. The entrance to the mine is in the south slope of Anthracite Mesa at an altitude of about 9,800 feet, or about 700 feet above the railway, with which it is connected by a gravity incline. The mine entries extend into the mesa toward the north under a cover of about 600 feet of rock.

Coal has been found at four horizons in Anthracite Mesa as shown in the following geologic section:

\section{Section of rocks measured near Anthracite mine.}

[For graphic section see fig. 29, No. 127, p. 171.]

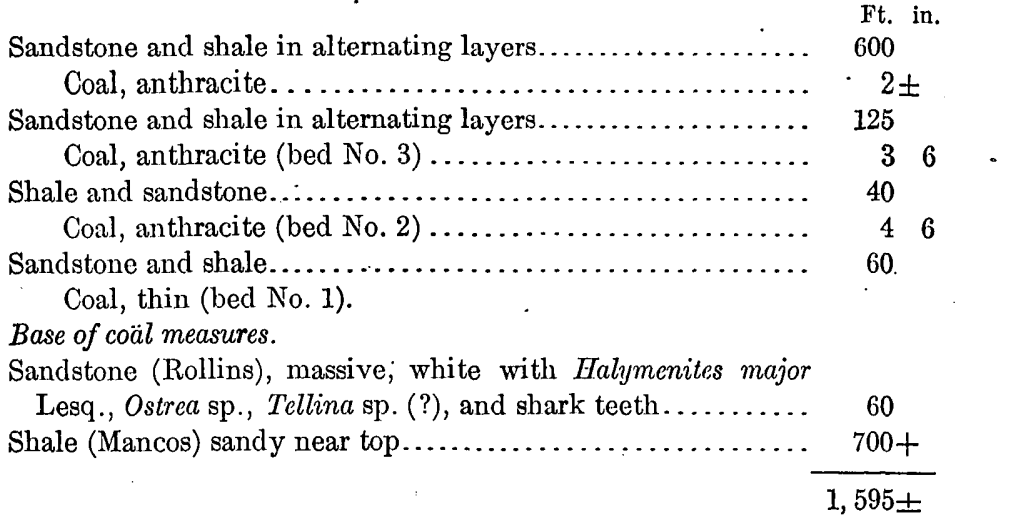

No satisfactory exposure of coal bed No. 1 was found near the Anthracite mine, but at several places farther northwest it was opened, and the coal was found to vary from a few inches to about 2 feet in thickness. In no place was it found clean enough to be of commercial value under present conditions.

Two coal beds have been worked in the Anthracite mine. The lower workings are in coal bed No. 2 of the above section, which has a maximum thickness of 6 feet, but is variable in thickness and character as shown in the sections presented graphically in figure 35 . In some places the coal is solid, but much of it is crushed to a powder and mixed with foreign matter. This crushed coal locally called "slack" contains greater percentages of ash than the solid coal and is avoided in mining.

The upper workings are in coal bed No. 3 , which is 40 feet above coal No. 2, and are much more extensive than those in the latter. Reports of production show that they were operated as early as 1884 and were productive from that time more or less continuously until they were 
abandoned in 1889 . These workings were inaccessible at the time of investigation, but a brief description of coal bed No. 3 published. by Eldridge in Geologic Survey Folio No. 9 is as follows:

The structure of this seam in this mine and in several of the neighboring prospects is peculiar. It shows a middle bench of solid jointed coal from 2 feet 6 inches to 4 feet thick and an upper and an under bench of a highly fractured chip variety, each varying from a knife edge to 18 inches. This structure has arisen from movement on stratification planes, a phenomenon not infrequent in the region of upper Slate Creek.

The highest bed shown in the foregoing section was not found near Anthracite mine; its horizon is fixed in Eldridge's section as 125 feet above coal bed No. 3. At locality No. 136 of the accompanying map, however, coal 2 to 3 feet thick was found in a position that suggests this highest bed.

Localities Nos. 128-135.-The coal beds of Anthracite Mesa have been extensively prospected, but many of the old prospect openings were inaccessible at the time of investigation, and because of the

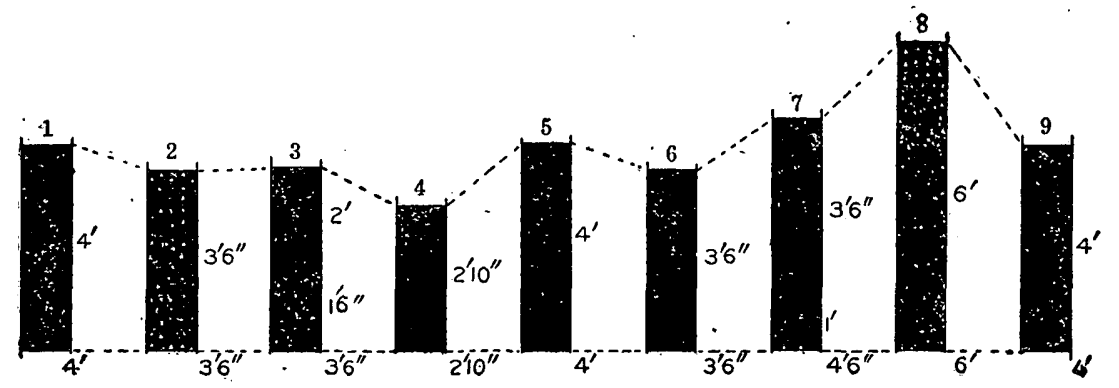

FIGURE 35.-Sections of coal in the lower workings of Anthracite mine, Anthracite, Colo. Sections 2, 3, 7 , and 8 contain crushed coal.

covering of brush and slide rock it is not possible to follow the outcrop of any bed continuously very far. In tracing the coal zone westward from the Anthracite mine, 3 feet of anthracite was found at locality No. 128 with shale above and below it. The lower 3 inches consists of crushed coal. A coal bed, apparently the same as that found at locality No. 128, contains a few hundred feet farther west 4 feet 8 inches of anthracite with shale above and below it, but whether this bed is coal No. 2 or No. 3 could not be definitely determined. Surface indications of the two beds of coal were found west of this locality, but no place was found where they could be opened with the means available. The rocks northwest of this locality are faulted and disturbed, and it is doubtful if coal beds No. 2 and No. 3 are of great economic importance north of sec.' 17, T. 13 S., R. 86 W., of the land net as projected on the accompanying map.

The lowest bed or coal No. 1 at locality No. 129 contains 1 foot 2 inches of anthracite coal, and the same bed at locality No. 130 is 1 foot thick. At locality No. 131, 1 foot 6 inches of anthracite coal 
was opened in bed No. 1, but it was found to be somewhat dirty and apparently of little value. The Rollins sandstone at these localities contains Halymenites major and characteristic invertebrates by which it is easily identified. It forms a more or less prominent cliff above which coal bed No. 1 can usually be found.

At the higher of the two prospects shown on the map at locality No. 132, the beds are steeply upturned and otherwise disturbed. No coal was found at this locality at the horizon of bed No. 1, but 1 foot 11 inches of anthracite with shale above and below it was found at a higher horizon. This bed is upturned to a nearly vertical positron. The strike of the coal is N. $52^{\circ} \mathrm{W}$. and the general dip is $22^{\circ}$ SW. Apparently faulting has occurred near this locality, dropping the beds east of the fault line. At the lower prospect shown at locality No. 132, surface indications of coal were found about 400 feet below the top of the mesa. There is a bed of anthracite coal 7 feet 4 inches thick 100 feet higher or 300 feet below the top of the mesa with shale above and below it. At locality No. 133 an old prospect opening shows a thickness of 5 feet 10 inches of anthracite with shale above and below it. At this locality the strike of the coal bed is N. $50^{\circ} \mathrm{W}$., and the dip is $20^{\circ} \mathrm{SW}$. Surface indications of coal were found 60 feet above this prospect, but the bed on being opened proved to contain little beside carbonaceous shale. At locality No. 134 the full thickness of the coal was not obtained; the part measured was 6 feet 10 inches thick. A prospect at locality No. 135, although lower than the opening of the last locality named, is apparently in the same bed of coal. The following section was measured at this locality:

Section of coal bed in Anthracite Mesa, at locality No. 195.

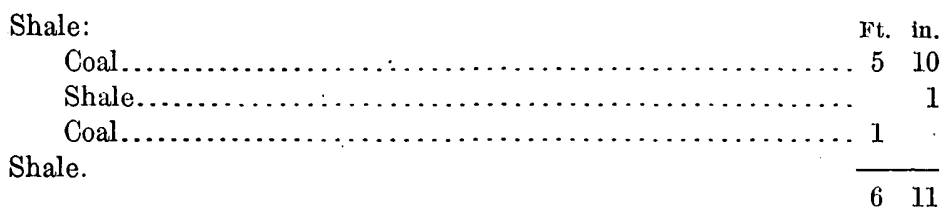

The results of these measurements are presented graphically in figure 36. It is not certain that these are all sections of the same bed. Indeed the fact that beds No. 2 and No. 3 have similar thicknesses where developed in the Anthracite mine renders it probable that some of the openings found may be in one bed and some in the other. The development within the mine is sufficient to show that both No. 2 and No. 3-coal beds extend throughout the mesa.

Locality No. 136.-At locality No. 136 two coal beds were found. The lower one has 3 feet or more of coal, but no place was found. where the undisturbed bed could be measured, and 60 feet abore this bed 2 feet of coal was found with shale above and below it. The position of these beds near the top of the mesa suggests that one of 
them may represent the coal bed shown in the geologic section of rocks in Anthracite Mesa as 233 feet above the base of the coal measures. On the other hand, the interval of 60 feet between them suggests the possibility that they may be coal beds No. 2 and No. 3. The great number of faults in Anthracite Mesa and the impossibility of following the coal beds continuously along the outcrop renders the correlation of these beds quite impossible at the present time.

East of the fault that trends northeast from Anthracite the rocks are more or less disturbed, and few satisfactory exposures of coal were found. Much prospecting had been done, but most of the old openings were inaccessible at the time of investigation. Anthracite coal has been found in some places and is still in evidence on the old dumps, but according to the report of people living in the neighborhood little coal of commercial value has been found east of the fault.

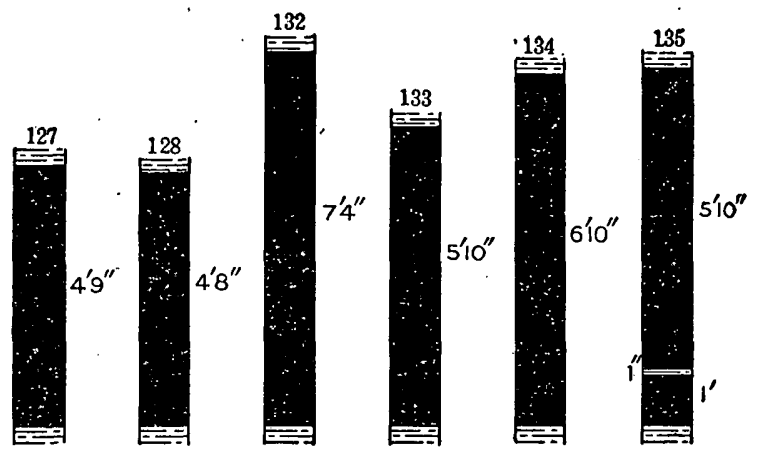

FiguRE 36.-Sections of coal measured in prospect openings at the outcrop in Anthracite Mesa.

At one prospect, however, locality. No. 137, a considerable amount of development work has been done. A coal bed opened up at this locality was measured near the mouth of the opening as follows:

Section of coal bed in Anthracite Mesa, at locality No. $19 \%$.

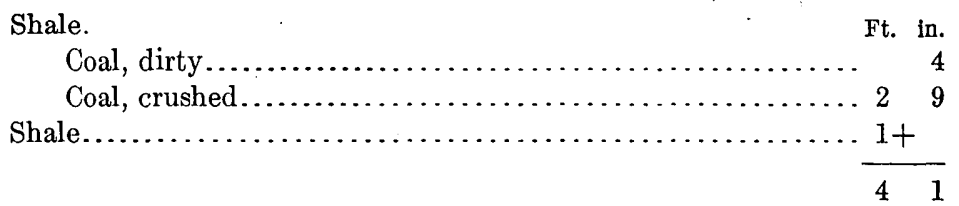

Another measurement farther in the entry shows 3 feet 3 inches of coal.

\section{QUANTITY OF COAL.}

Because of the uncertainty in many places as to the number of coal - beds and the still greater uncertainty as to their variations in thickness, no close estimate can be made of the quantity of coal in the Grand Mesa and West Elk Mountain coal fields until more information 
is available. However, a computation of tonnage based on conservative estimates of thickness may be of some value in showing the great quantity of coal available in these fields. It is probable that more than the estimated tonnage of coal will be found. The areas, the estimated thicknesses of coal, and the tonnages for the various districts and fields are given in tabular form below. The workable coal in the Rollins district and to some extent also that in the Somerset district of the Grand Mesa field extends northward under the mesa beyond the area mapped. Only the areas represented on the accompanying map are included in these computations. Coal of 1.3 specific gravity weighs 81.25 pounds per cubic foot and a square mile of this coal one foot thick contains 1,132,544 short tons.

Area, thickness of coal, and estimated tonnage in round numbers for the fields and districts of the Grand Mesa and West Elk Mountain coal fields.

\begin{tabular}{|c|c|c|c|}
\hline District or field. & Area. & $\begin{array}{l}\text { Average } \\
\text { thick- } \\
\text { ness. }\end{array}$ & \\
\hline 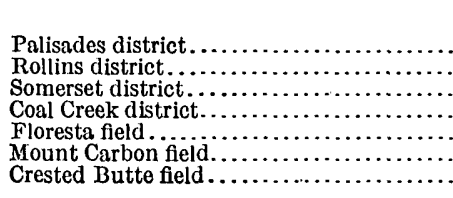 & $\begin{array}{r}S q . m . \\
129 \\
127 \\
75 \\
105 \\
17 \\
61 \\
42\end{array}$ & $\begin{array}{r}\text { Feet. } \\
11 \\
15 \\
65 \\
44 \\
4 \\
12 \\
15\end{array}$ & $\begin{array}{r}\text { Short tons. } \\
1,607,080,000 \\
2,157,496,000 \\
5,621,152,000 \\
5,232,353,000 \\
77,013,000 \\
829,022,000 \\
713,503,000\end{array}$ \\
\hline 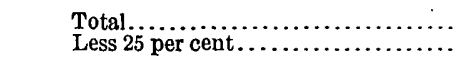 & 556 & & $\begin{array}{r}16,237,619,000 \\
4,059,405,000\end{array}$ \\
\hline Available for mining........ & & & $12,178,214,000$ \\
\hline
\end{tabular}

QUALITY OF COAL.

\section{COLLECTION OF SAMPLES.}

Samples of coal were collected from all of the mines and from the principal prospects examined; also from some of the surface exposures. These samples were analyzed in the fuel-testing plant of the United States Geological Survey at Pittsburgh, Pa.

The results of 55 analyses made of the coals from the Grand Mesa and West Elk Mountain coal fields are presented in the table below, and 30 analyses of coal from the Anthracite and Crested Butte quadrangles made many years ago in the chemical laboratory of the Survey and published in Folio 9 are here republished. All of the samples taken during the investigations of 1907,1909 , and 1910 were collected and treated according to the methods adopted for the United States Geological Survey, as follows: The face of the bed at each place selected for taking a sample was first cleared of weathered coal, powder smoke, etc., in order that coal as nearly as possible unchanged by any superficial agency might be obtained. Two trenches 1 to 3 inches deep were cut across the bed from roof to floor leaving a $V$-shaped 
ridge about 3 inches wide. This ridge containing 25 to 75 pounds of coal was then removed from the face and caught on an oilcloth or a piece of canvas spread on the floor of the mine in order that no moisture or other foreign matter from the floor might be included in the sample. In removing the coal from the face of the bed all partings of bedded impurity such as shale and bone were carefully removed in order that the sample might represent only the marketable coal. In some cases it was not practicable to sample the entire bed. The coal thus caught on the canvas was broken into fragments less than half an inch in diameter, thoroughly mixed, and quartered down by the method ordinarily followed in preparing samples of ore for analysis until about 4 pounds of coal remained on the cloth. This was placed in an air-tight galvanized iron can, sealed with adhesive tape or melted paraffin, and mailed as soon as convenient to the fuel-testing laboratory, where it was analyzed.

CHEMICAL ANALYSES.

The results of the analyses made are given in the tables presented on pages 201-209. 
QUAALITYY OF COOAL.

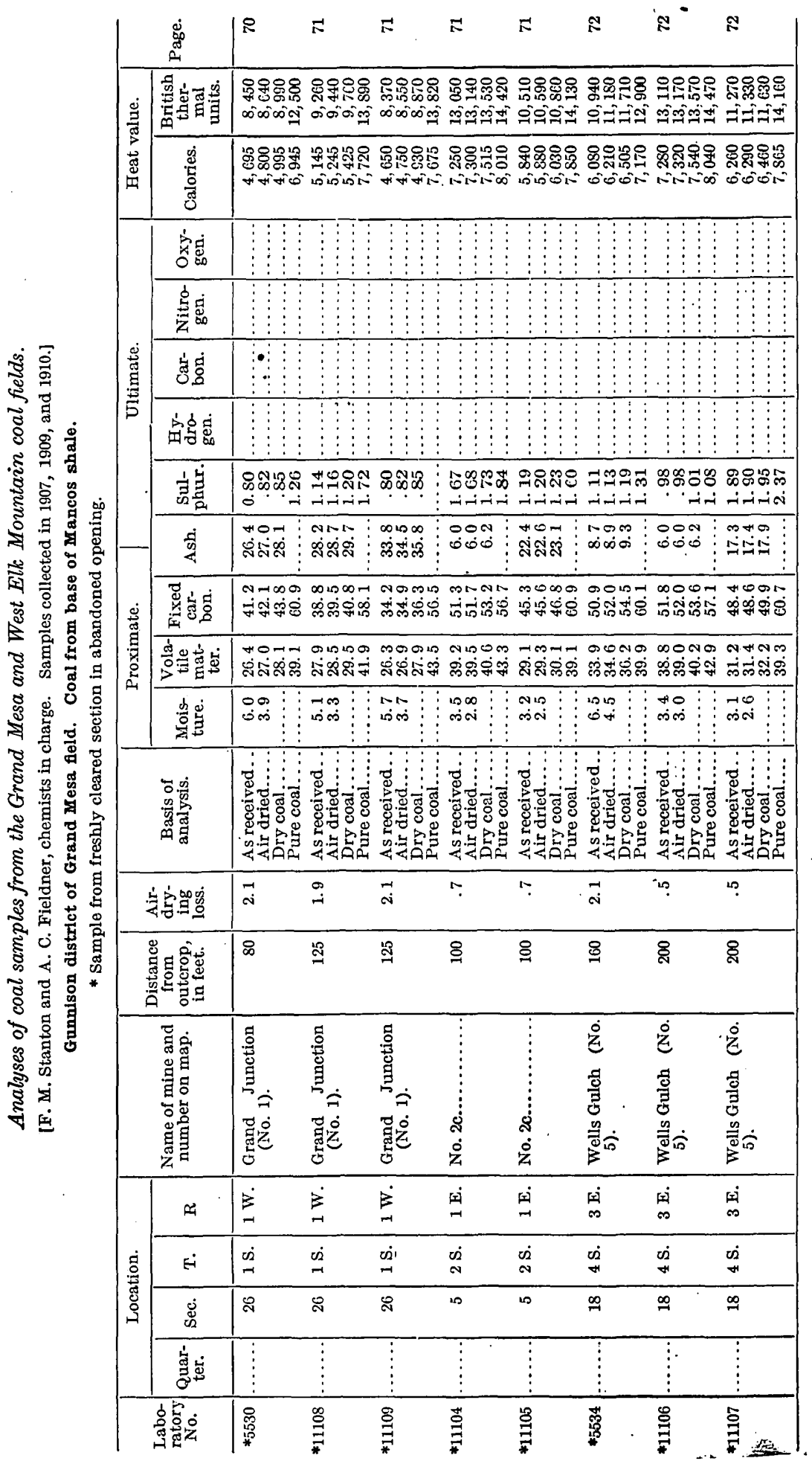




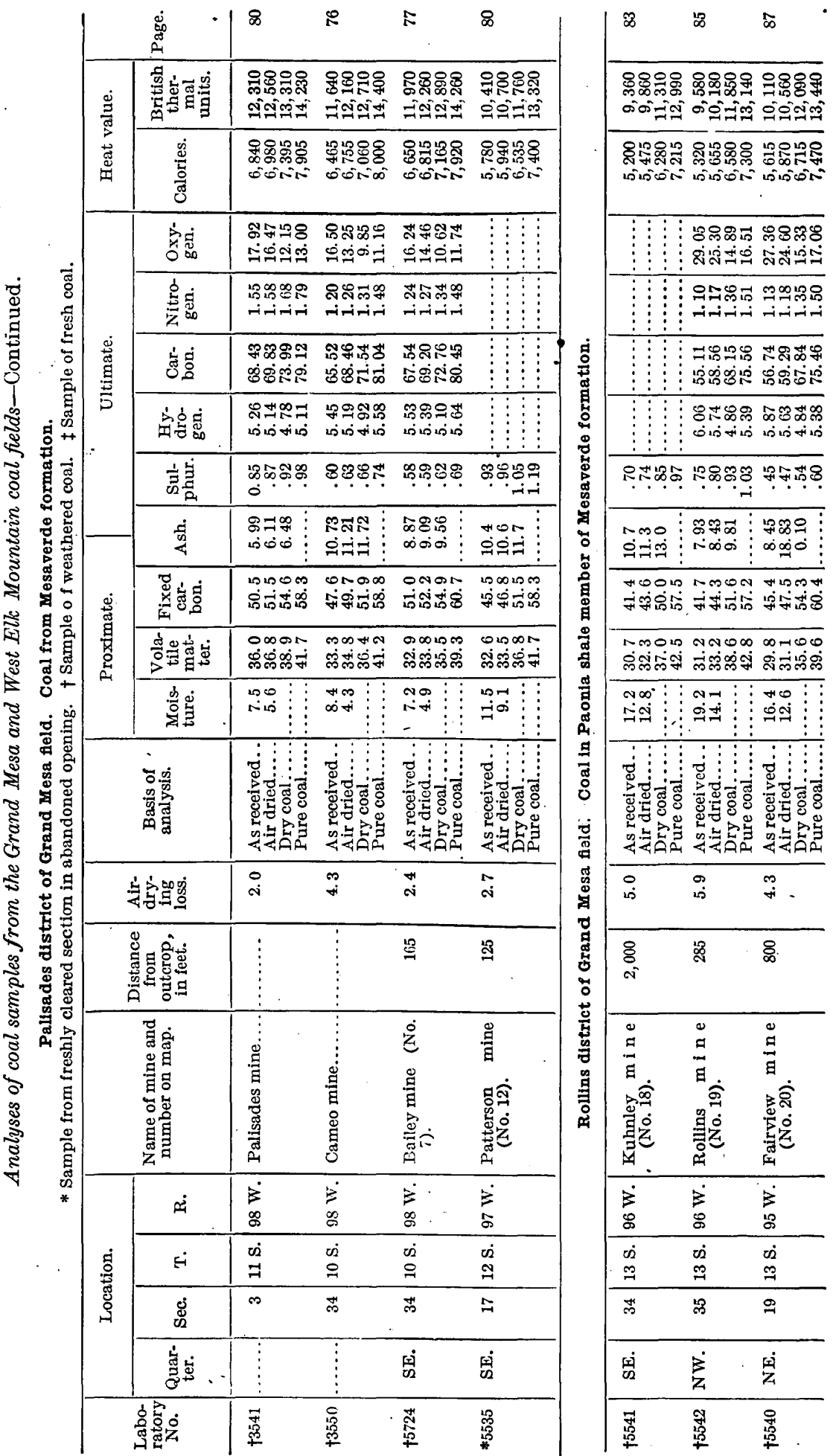




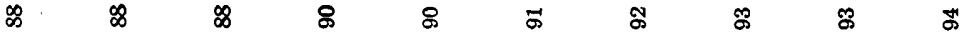

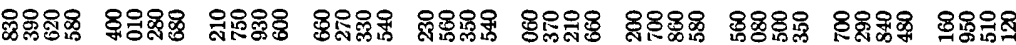

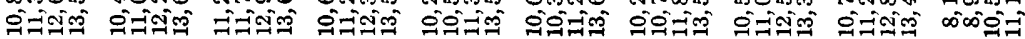

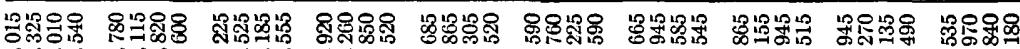

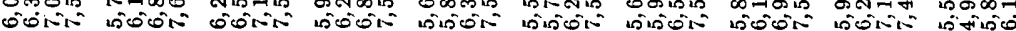

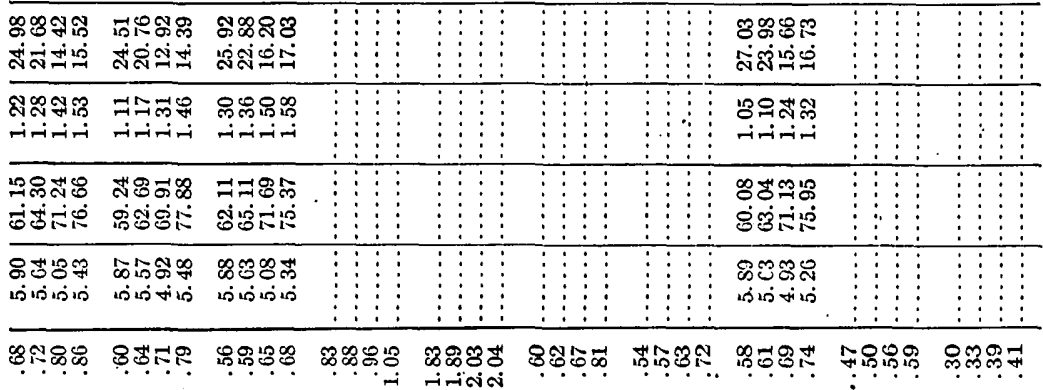

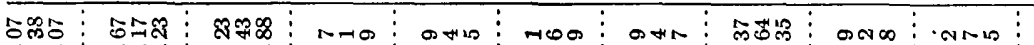

மor

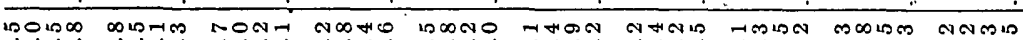

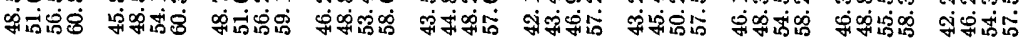

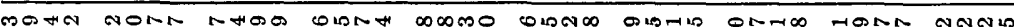

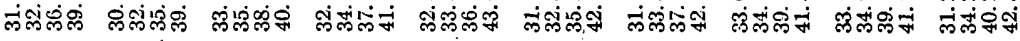

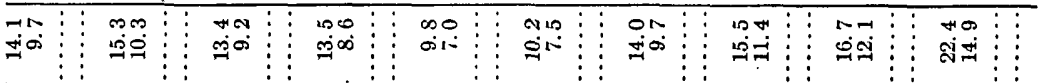

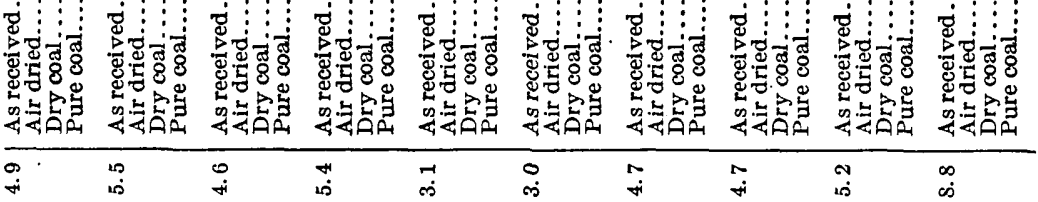

\& 8 \& 윰 윰 \& \&

\begin{tabular}{|c|c|c|c|c|c|c|c|c|c|}
\hline 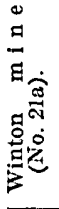 & 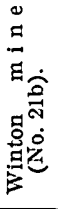 & 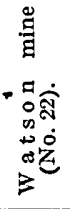 & 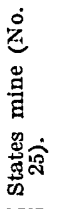 & 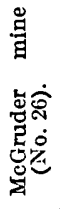 & 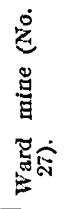 & 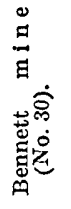 & 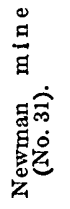 & 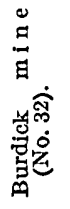 & 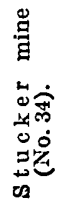 \\
\hline$\stackrel{\overrightarrow{8}}{\overrightarrow{8}}$ & $\begin{array}{l}\dot{3} \\
\mathrm{~s}\end{array}$ & $\begin{array}{l}\dot{8} \\
8\end{array}$ & $\dot{\overrightarrow{8}}$ & 莕 & $\vec{\sigma}$ & $\underset{\%}{\infty}$ & 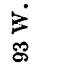 & \& & $\dot{8}$ \\
\hline $\begin{array}{l}\dot{U} \\
\stackrel{\Phi}{*}\end{array}$ & $\begin{array}{l}\dot{\infty} \\
\stackrel{\Xi}{2}\end{array}$ & $\begin{array}{l}\dot{D} \\
\stackrel{\infty}{-}\end{array}$ & $\begin{array}{l}\dot{\mathscr{D}} \\
\stackrel{\Xi}{\Omega}\end{array}$ & $\begin{array}{l}\dot{\infty} \\
\ddot{n}\end{array}$ & $\begin{array}{l}\dot{m} \\
\dot{M}\end{array}$ & $\begin{array}{l}\dot{D} \\
\dot{M}\end{array}$ & $\begin{array}{l}\dot{2} \\
\mathbb{M}\end{array}$ & $\begin{array}{l}\dot{0} \\
\ddot{M}\end{array}$ & $\begin{array}{l}\dot{\ddot{L}} \\
\ddot{\sim}\end{array}$ \\
\hline$\stackrel{\mathscr{\sigma}}{\pi}$ & $\stackrel{2}{2}$ & $\Rightarrow$ & $\dddot{\eta}$ & 29 & $\cong$ & $\tilde{\pi}$ & ఝి & ి్లి & $\vec{N}$ \\
\hline
\end{tabular}

\begin{tabular}{|c|c|c|c|c|c|c|c|c|c|}
\hline$\vec{z}$ & $\vec{z}$ & 宦 & 舁 & 孚 & घ่ & $\dot{z}$ & 妾 & $\sum_{n}$ & 要 \\
\hline 谙 & $\begin{array}{l}\text { 吕 } \\
\text { 营 }\end{array}$ & $\begin{array}{l}\text { 藏 } \\
\text { 量 }\end{array}$ & $\begin{array}{l}\text { \% } \\
\text { 吊 } \\
\end{array}$ & $\begin{array}{l}\mathbb{N} \\
\text { : }\end{array}$ & $\begin{array}{l}\infty \\
\text { 范 } \\
\text { F }\end{array}$ & 范 & $\begin{array}{l}\text { 范 } \\
\text { 喿 }\end{array}$ & 兽 & 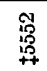 \\
\hline
\end{tabular}


COAL OF GRAND MESA AND WEST ELK MOUNTAINS, COLO.

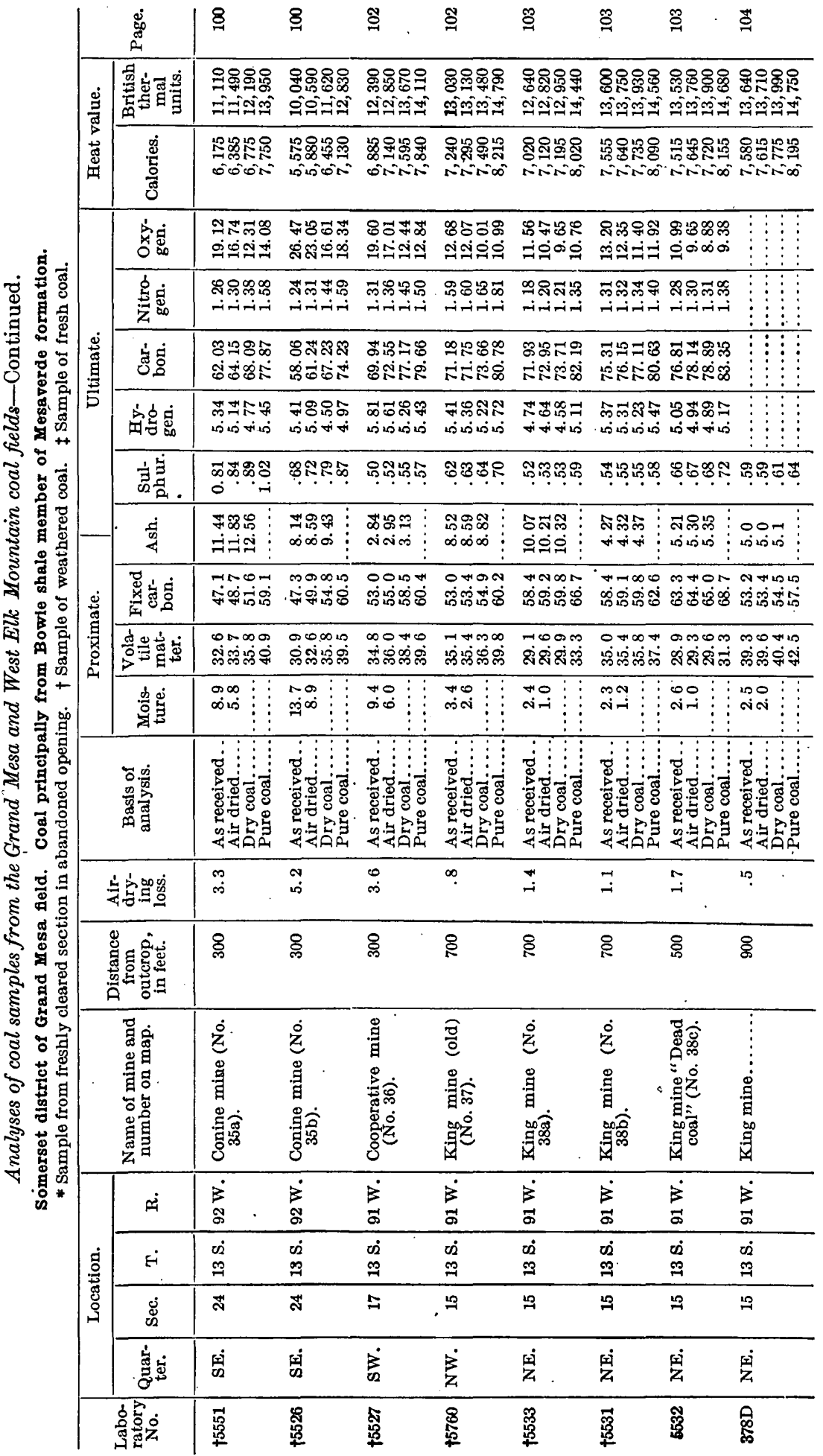




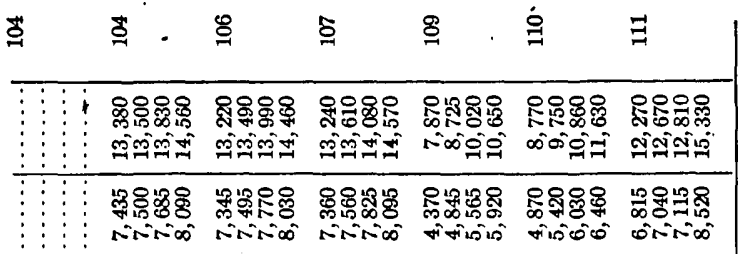

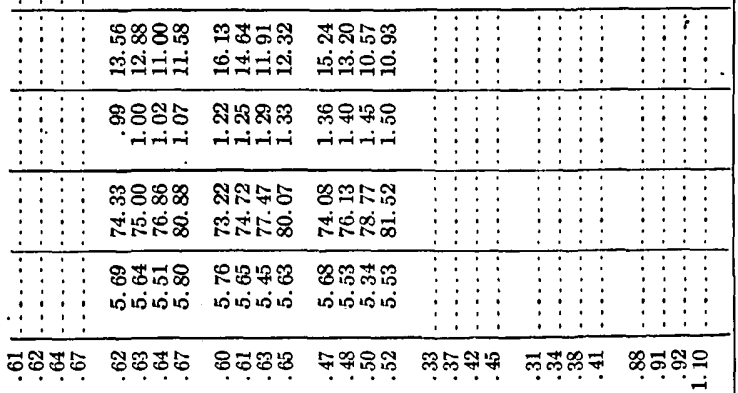

\begin{tabular}{|c|c|c|c|c|c|c|}
\hline 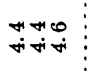 & 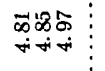 & 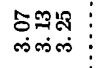 & 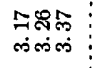 & $\begin{array}{l}\text { NeNo } \\
\text { rius is }\end{array}$ & 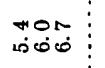 & 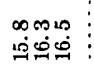 \\
\hline 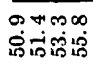 & 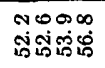 & 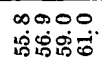 & 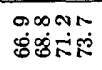 & 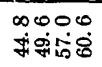 & 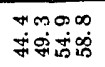 & $\begin{array}{l}0 \ln 0 \\
\text { gogisio }\end{array}$ \\
\hline 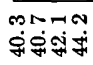 & 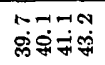 & 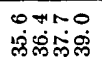 & 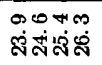 & 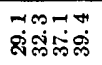 & 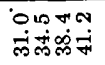 & 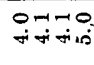 \\
\hline $\begin{array}{l}+\pi 0 \\
\text { Tin }\end{array}$ & $\stackrel{\infty}{\infty \pi}$ & 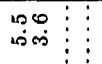 & om & $\begin{array}{l}\text { Ho } \\
\text { تंن }\end{array}$ & 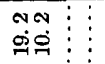 & $\stackrel{\text { N. }}{\sim}$ \\
\hline
\end{tabular}

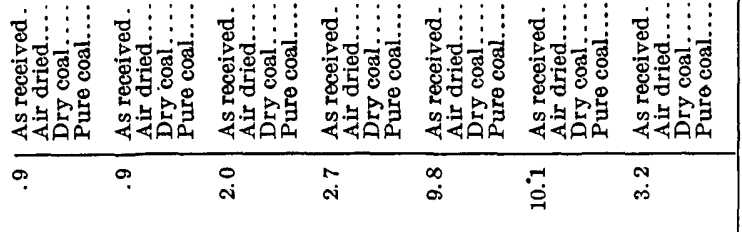

\begin{tabular}{l|lll|l|l|l|l}
\hline 8 & & 8 & 8 & $\vdots$ & & 8 \\
\hline-1 & $\vdots$ & & & & & & \\
\hline
\end{tabular}

\begin{tabular}{|c|c|c|c|c|c|c|}
\hline $\begin{array}{l}\text { 吕 } \\
\text { 量 } \\
\text { 范 }\end{array}$ & 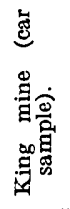 & 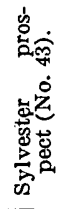 & 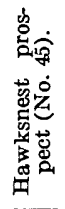 & 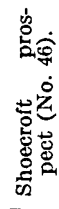 & 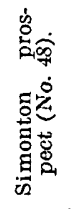 & $\begin{array}{l}\text { 号 } \\
\text { 品 } \\
\text { 泀 }\end{array}$ \\
\hline$\frac{1}{6}$ & $\vec{\sigma}$ & 8 & 8 & & 8 & \\
\hline$\stackrel{\infty}{\infty}$ & $\begin{array}{l}\dot{\infty} \\
m \\
m\end{array}$ & $\begin{array}{l}\dot{m} \\
\stackrel{2}{2}\end{array}$ & $\stackrel{\dot{Q}}{\stackrel{2}{2}}$ & & $\begin{array}{l}\dot{0} \\
\dot{H}\end{array}$ & \\
\hline 륵 & $\stackrel{20}{2}$ & 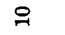 & $=$ & & స̃ & \\
\hline 兒 & 靣 & & : & $\vdots$ & : & \\
\hline 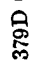 & 㞔 & 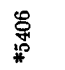 & 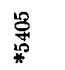 & $\begin{array}{l}\text { 总 } \\
\text { 㔛 }\end{array}$ & 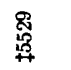 & $\begin{array}{l}\not \\
\stackrel{p}{p} \\
\stackrel{p}{p}\end{array}$ \\
\hline
\end{tabular}

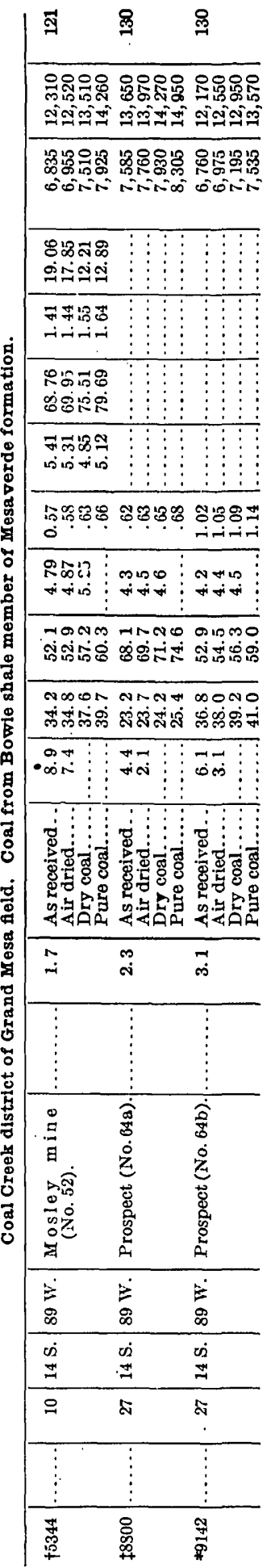




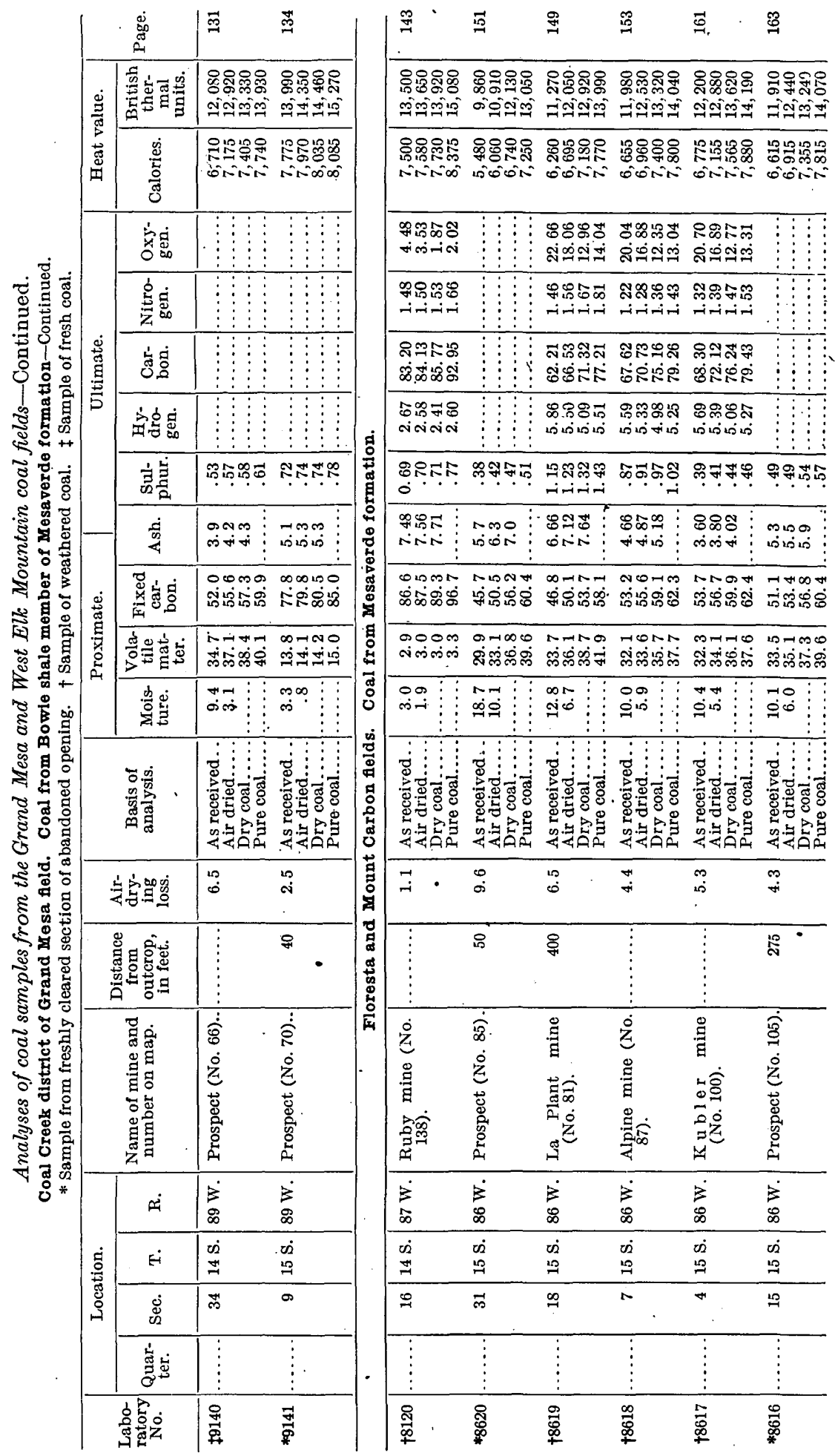




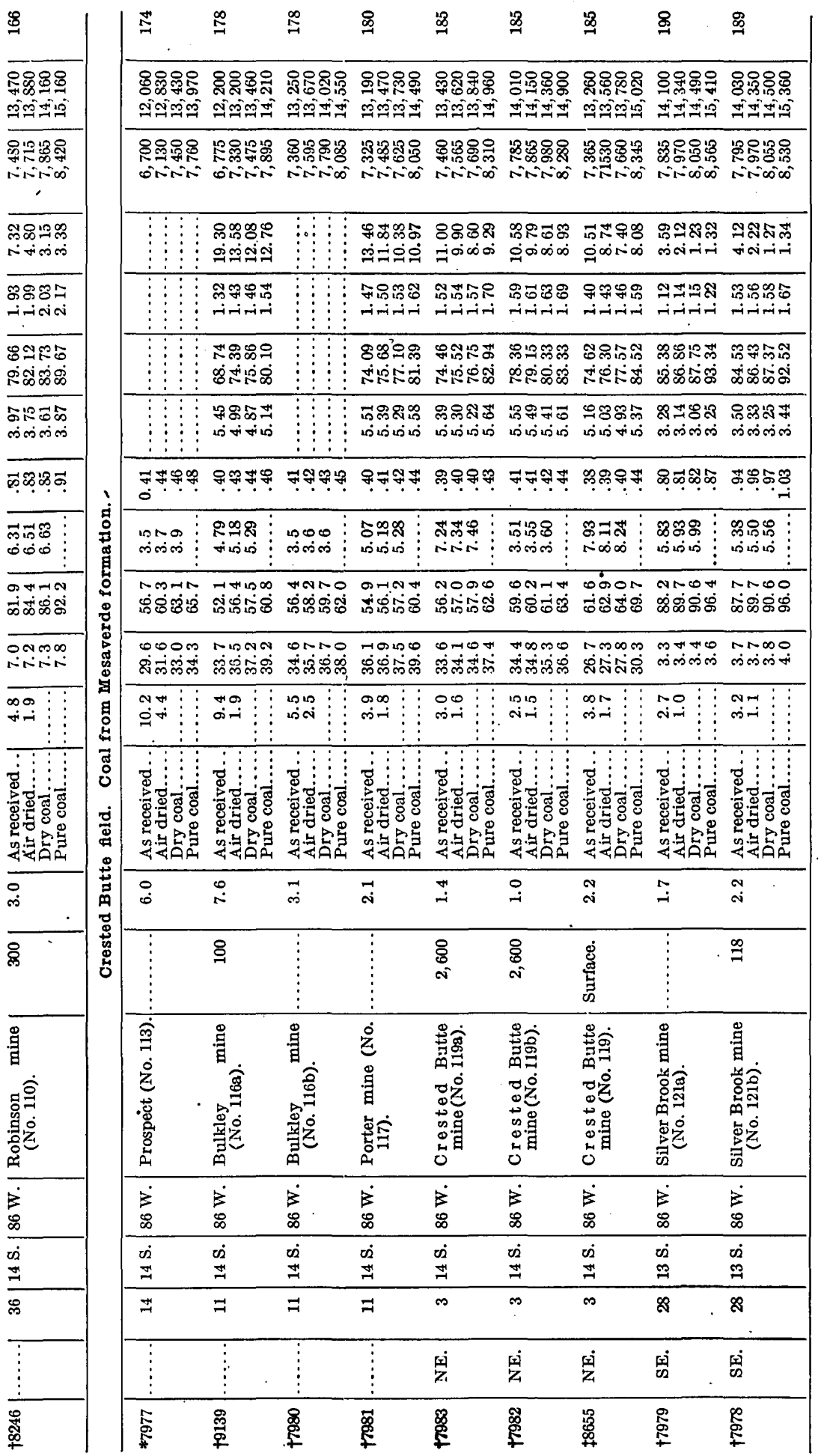




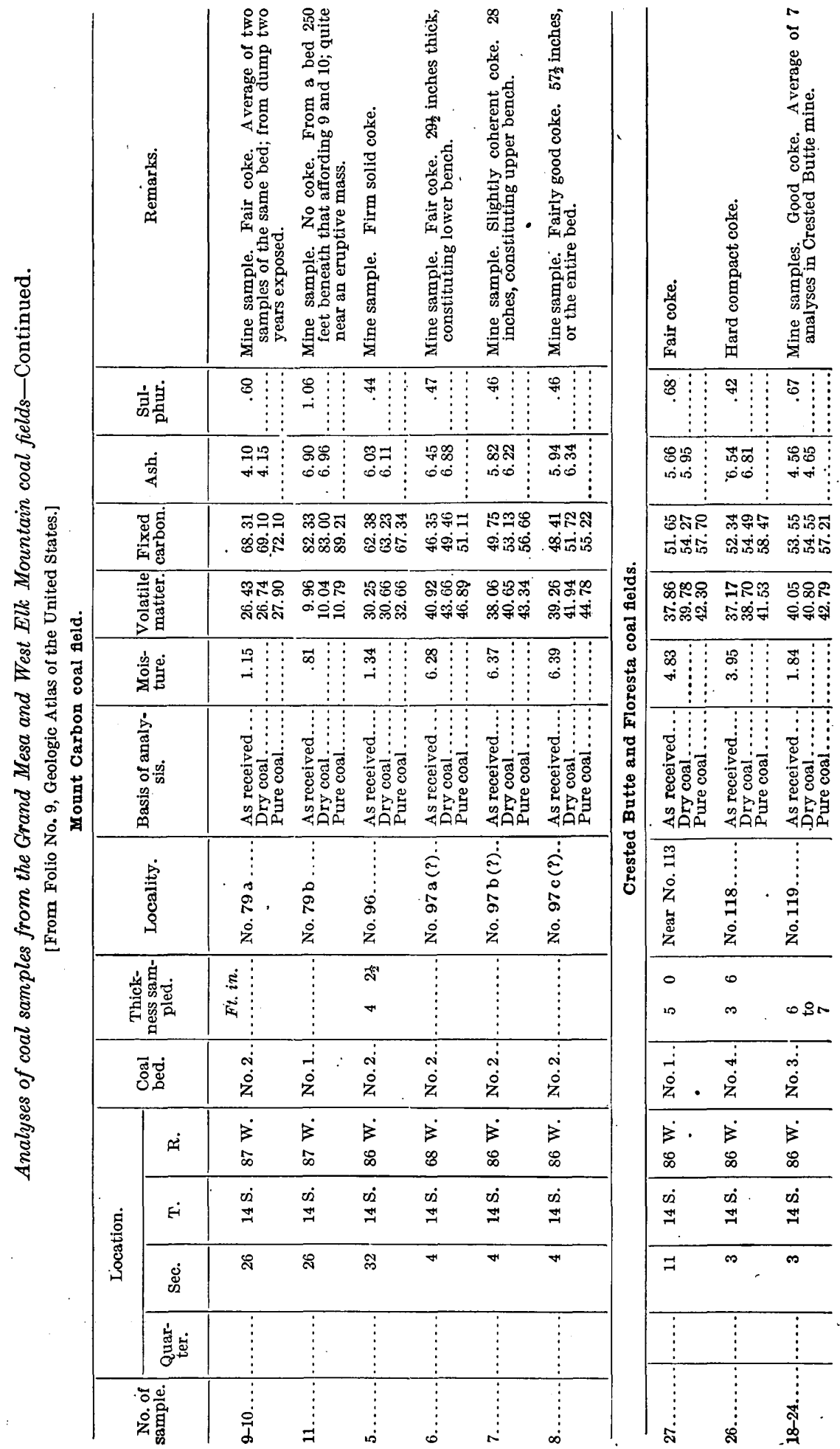




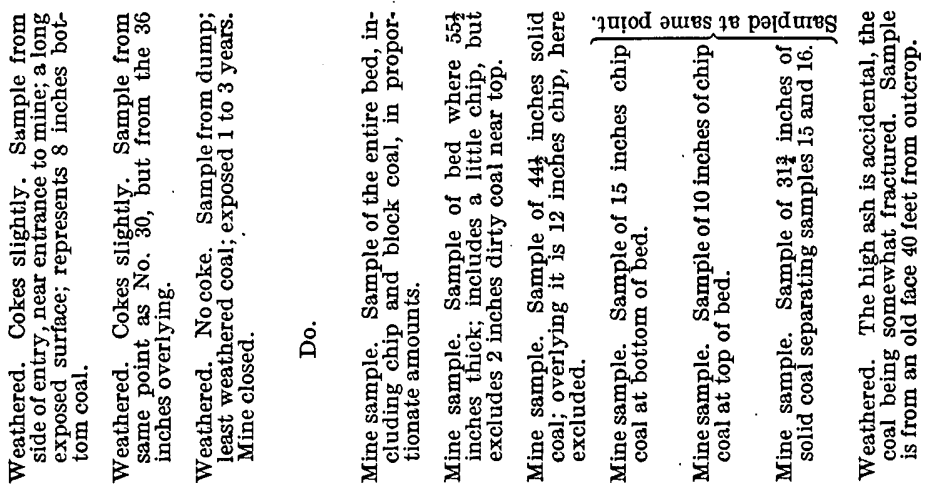

땜ำ

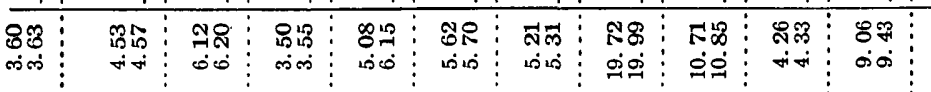

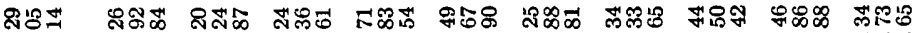

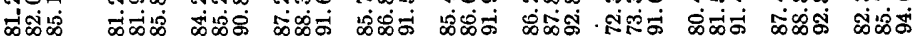

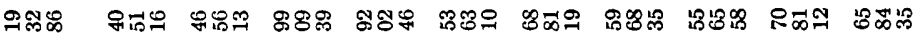
पid

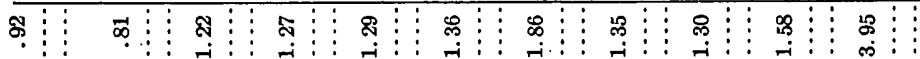

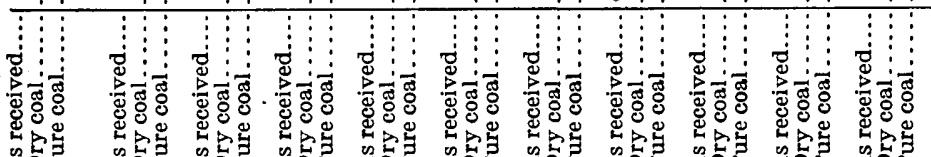

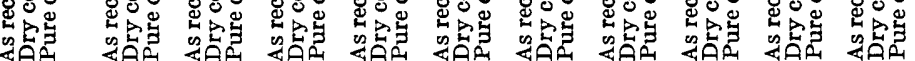

\begin{tabular}{|c|c|c|c|c|c|c|c|c|c|c|}
\hline 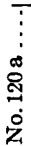 & 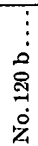 & 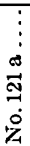 & 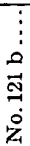 & 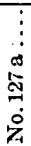 & $\begin{array}{l}\stackrel{0}{\tilde{N}} \\
\dot{\mathrm{O}} \\
\dot{\mathrm{z}}\end{array}$ & 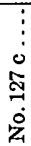 & 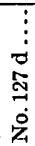 & 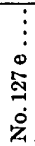 & 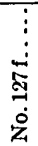 & 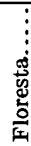 \\
\hline
\end{tabular}

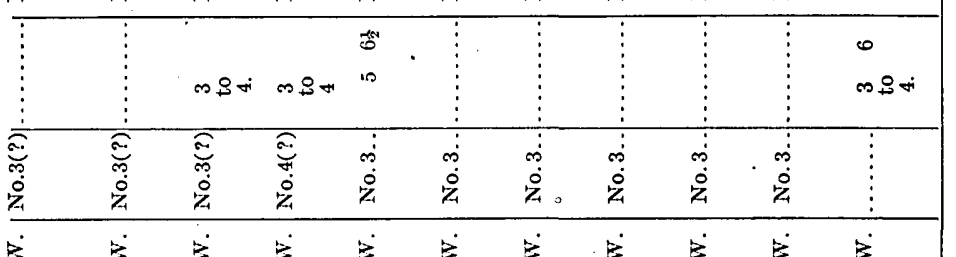

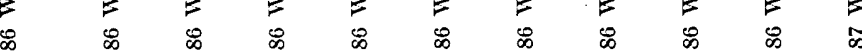

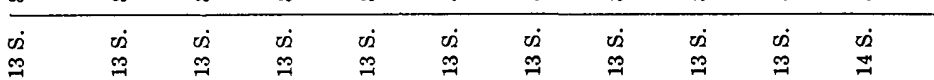

๓

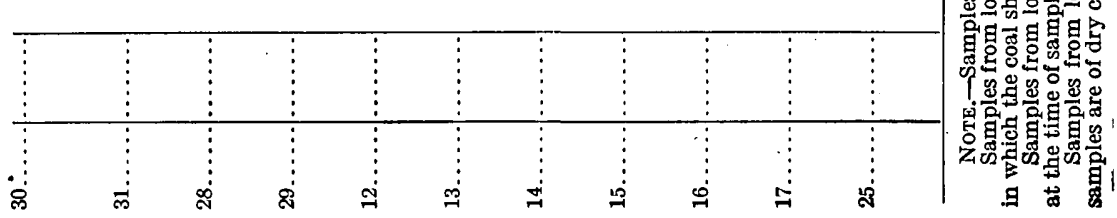

40642 - Bull. 510-12-14 


\section{CHARACTER OF COAL RELATIVE TO ORIGIN AND TO META- MORPHISM.}

The coal beds of Grand Mesa proper have not been greatly disturbed and have not been metamorphosed except locally, but in the southeastern part of the Grand Mesa field the coals have been more generally affected. The analyses of the unchanged coals furnish the best basis for judging of the original character of the coal of the Grand Mesa and West Elk Mountain region. In general the Paonia coals are of soft, subbituminous, noncoking quality, and the Bowie coals are hard, relatively high-grade bituminous, some of them being coking coals. In most places it was quite impossible to take samples far enough from the outcrops of the coal beds to be certain of obtaining coal that was not affected by surface exposure, burning at the outcrop, etc. However, six of the samples of Paonia coal and six of the samples of Bowie coal probably were very little changed and represent unweathered material. They are selected from localities as widely separated as possible, but not including any points in the areas obviously affected by metamorphism. The analyses of these samples have been averaged in the following table to show the general differences in character between the coals in rocks mainly of fresh-water origin and those contained in the rocks mainly of marine and brackish-water origin in the Grand Mesa field.

\section{Average composition of coal in the Grand Mesa field.}

Paonia coal.

[Samples collected from mines at localities Nos. 19, 20, 21a, 21b, 22, and 31.]

\begin{tabular}{|c|c|c|c|c|c|c|c|c|c|c|c|c|}
\hline & $\begin{array}{l}\text { Air- } \\
\text { dry- } \\
\text { ing } \\
\text { loss. }\end{array}$ & $\begin{array}{l}\text { Mois- } \\
\text { ture. }\end{array}$ & $\begin{array}{l}\text { Vola- } \\
\text { tile } \\
\text { mat- } \\
\text { ter. }\end{array}$ & $\begin{array}{l}\text { Fixed } \\
\text { car- } \\
\text { bon. }\end{array}$ & Ash. & $\left|\begin{array}{c}\text { Sul- } \\
\text { phur. }\end{array}\right|$ & $\begin{array}{l}\text { Hy- } \\
\text { dro- } \\
\text { gen. }\end{array}$ & $\begin{array}{l}\text { Car- } \\
\text { bon. }\end{array}$ & $\begin{array}{c}\text { Nitro- } \\
\text { gen. }\end{array}$ & $\begin{array}{l}\text { Oxy- } \\
\text { gen. }\end{array}$ & $\begin{array}{l}\text { Calo- } \\
\text { ries. }\end{array}$ & B. t. u. \\
\hline $\begin{array}{l}\text { As received. } \\
\text { Air dried.... } \\
\text { Dry coal... } \\
\text { Pure coal.... }\end{array}$ & 4. 98 & $\begin{array}{l}15.64 \\
11.21\end{array}$ & $\begin{array}{l}31.54 \\
33.20 \\
37.40 \\
42.47\end{array}$ & $\begin{array}{l}46.03 \\
48.43 \\
54.53 \\
59.70\end{array}$ & $\begin{array}{l}6.78 \\
7.15 \\
8.07\end{array}$ & $\begin{array}{l}.60 \\
.64 \\
.72 \\
.78\end{array}$ & $\begin{array}{l}5.91 \\
5.64 \\
4.95 \\
5.38\end{array}$ & $\begin{array}{l}59.07 \\
62.17 \\
69.99 \\
76.15\end{array}$ & $\begin{array}{l}1.15 \\
1.21 \\
1.36 \\
1.49\end{array}$ & $\begin{array}{l}26.47 \\
23.20 \\
14.57 \\
16.21\end{array}$ & $\begin{array}{l}5,804 \\
6,108 \\
6,876 \\
7,479\end{array}$ & $\begin{array}{l}10,447 \\
10,994 \\
12,363 \\
13,463\end{array}$ \\
\hline
\end{tabular}

Bowie coal.

[Samples collected from mines at Iocalities Nos. 35a, 35b, 36, 37, 38a, and 38b.]

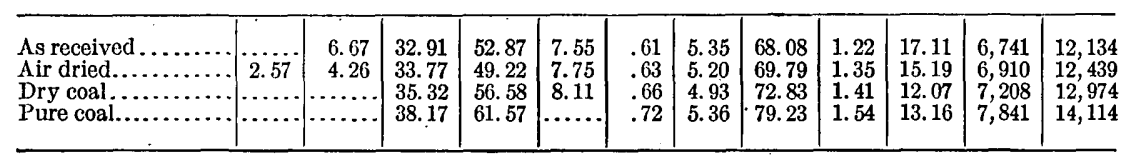

In the Coal Creek district and in the small fields farther east where the sedimentary rocks have been disturbed by the igneous intrusions of the West Elk Mountains the coals have all been more or less metamorphosed. Some are noncoking and others are coking bituminous coals. Some are semibituminous, others semianthracite, and still others are anthracite. Probably a complete series of gradations 
from subbituminous coals to anthracite can be found in these fields. At some localities apparently the metamorphism is wholly regional, and bodies of igneous rock that are almost in contact with the coal have produced remarkably little change in its quality. In other localities the metamorphism is obviously of limited extent and is due to the proximity of intrusive igneous rock. In the tables of analyses the numbers denoting "pure coal" best indicate the degree of metamorphism because of the exclusion of moisture and ash from the results. The British thermal units of the "pure coal" analyses when plotted as in figure 37 show somewhat strikingly the variations in the degree of metamorphism. The curve thus plotted may serve to show some of the relations described in the following paragraphs.

It is known that in some regions the metamorphism of coal has decreased its heating value, but there seem to be good reasons for believing that in the Grand Mesa and West Elk Mountain coal fields the metamorphism of the coal has increased its fuel value. Chief among these reasons are the obvious increase in value toward the centers of metamorphic action and the fact that metamorphosed coal of certain beds has higher heating value than the unmetamorphosed coal of the same beds. This is illustrated in the Crested Butte field where the bituminous coals of localities Nos. 114 to 117 change in character to some extent within the Crested Butte mine and appear as anthracite at locality No. 121 with an

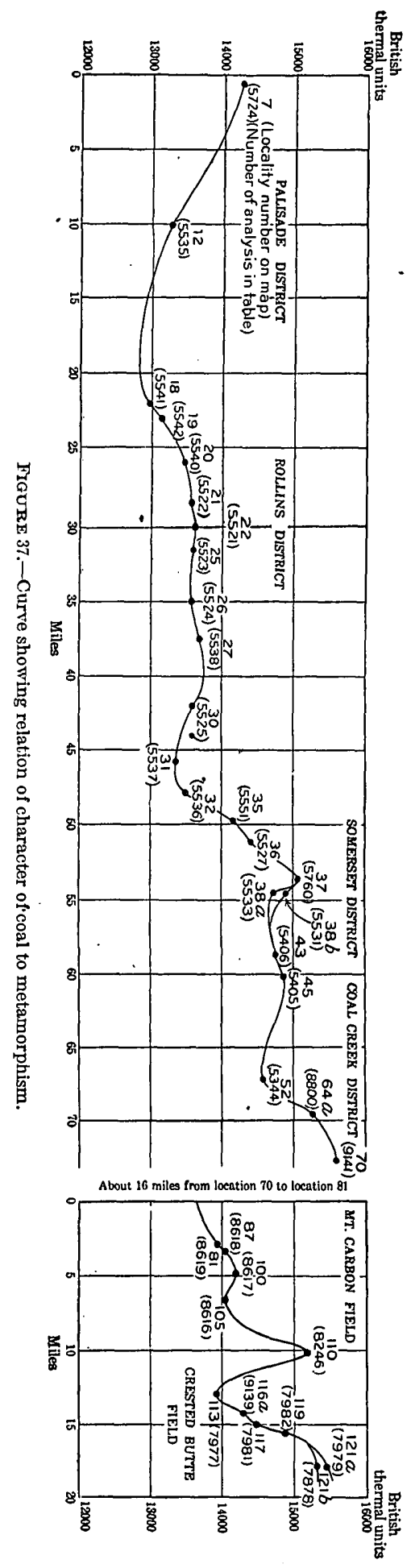


increase of more than 1,200 British thermal units computed on the ash-and-moisture-free basis. This change takes place in a distance of little more than 3 miles. On the other hand, further investigation may prove that the observed differences in the quality of the coals may be due to causes other than metamorphism.

The coal of Benton age in the Gunnison district of the Grand Mesa field is probably of little commercial value because of the irregularity of the beds and because of the poor quality of the coal, which is dry and dirty and does not burn readily. The samples collected from this district are from abandoned mines, and the coal in each of them obviously had deteriorated because of exposure to the weather. However, this exposure in the old openings can not wholly account for the poor quality of coal shown by the analyses. The bed is under thin cover and weathering has doubtless been in slow progress for a long time. On account of the doubtful character of this coal, it may be omitted at the present time from any consideration of the commercial value of the Grand Mesa coal field.

The coal of the Palisades district is much more important. It ranges in character from subbituminous to bituminous. The lowest bed, represented by analysis No. 3541, is in the Bowie shale member of the Mesaverde formation-a member which in the Somerset district contains higher grade coals than those of the overlying Paonia shale member. The Paonia coals are generally of relatively low grade, but near Palisades these coals, represented by analyses No. 3550 and No. 5724 of the table on page 202, are of essentially the same character as the Bowie coal, possibly from some local cause. Among the possible causes of this change may be mentioned, first, a sharp upturning of the sedimentary rocks that has occurred a short distance northwest of these localities, and, second, the burning of the coal near the outcrop. The latter cause applies especially to locality No. 7 (analysis No. 5724) where the mine opening is located close to an area from which the coal has been burned away. The only. sample collected from the southern part of the Palisades district is from the Patterson mine, an abandoned opening in which the quality of the coal is probably affected to some extent by weathering. No samples of coal were collected for analysis from the Palisades district south of locality No. 12 and the character of the coal in the southern part of the area is best indicated by the analyses of samples collected from the nearest mines in the Rollins district, Nos. 5541 and 5542 of the table of analyses on page 202. The coal is soft, weathers readily, and slacks on exposure to the atmosphere. It probably would not endure shipping for long distances without considerable deterioration.

The coal beds of the Rollins district are all in the Paonia or freshwater member of the Mesaverde formation, and the coal is fairly uniform in character throughout the district, a fact shown graphically 
in numbers 18 to 32 of figure 37 , page 211 . It is a soft, black, noncoking, subbituminous coal that slacks quickly when exposed to the weather. It takes fire easily in the mines and at the outcrop and has burned near the surface in many places. The Paonia coals usually contain high percentages of moisture and rather low percentages of ash, and show low heating values. They contrast strongly with the Bowie coals which have low percentages of moisture and high heating values. They burn easily and are used almost entirely as domestic fuel in the towns near the mines. They probably could not be shipped for long distances without crumbling badly and otherwise deteriorating.

The coal beds in the Somerset district-localities 35 to 45 of figure 37 , page $211-$ occur in both the Bowie and the Paonia members of the Mesaverde formation.' The soft bituminous coals of the Paonia, best known in the Rollins district, extend into the Somerset district but have been opened in only a few places, and no samples of these soft coals were there collected for analysis. The Bowie coals are commercially greatly superior to the Paonia coals, except where the quality of the latter is improved by metamorphism. They are tough, black, bituminous coals that do not slack readily upon exposure to the weather and are shipped without notable deterioration. The analyses show rather low contents of ash and moisture and high heating values. Some of the coals are known to be of coking quality but others apparently will not coke. The differences between the Bowie and the Paonia coals may be due partly to difference in age and partly to original composition. The Bowie coals contained in rocks of marine and brackish-water origin are older than the Paonia coals, which are of fresh-water origin. The difference in the heating values of these coals is shown graphically in figure 37, page 211. Nos. 43 , and 45 in this figure are supposed to be metamorphosed Paonia coals.

The effect of age is shown in a smaller way at localities Nos. 37 and 38. The sample collected at locality No. 37 was taken from the oldest bed and shows a higher heating value than that from locality No. 38 where the coal bed is stratigraphically higher, that is, younger, than that at locality No. 37. The sample collected from No. 38a represents the upper bench of the bed at locality No. 38 and has lower heating value than the sample collected from No. $38 \mathrm{~b}$, which represents the lower bench. At several mines in the Grand Mesa field, according to report, the lower bench contains coal of superior quality to that of the upper bench in the same mine. At localities Nos. 43 and 45, the coals that are supposed to be in the Paonia member have apparently been changed by metamorphism from noncoking subbituminous varieties, characteristic of this member farther west, to relatively high-grade coking varieties that compare 
favorably with the coals of the older beds. As a general rule, the older coals of Grand Mesa are superior to the younger ones, but there are many exceptions, and considerable caution should be exercised in applying the rule. In and near the West Elk Mountains, where the coals have been more or less metamorphosed; this rule does not hold good.

Less is definitely known of the coals of the Coal Creek district than is known of those of the Somerset district. They have been prospected in many places, but in only one place, locality No. 52 of the accompanying map, has any coal been mined for use. Therefore the samples collected in this district are all more or less affected by weathering, although care was taken to secure as fresh coal as possible, and the unweathered coal of Coal Creek district will doubtless prove to be better than is indicated by the analyses. Of the five analyses given in the table, No. 5344 most nearly represents fresh coal. Most of the coal is of bituminous quality and much of it will coke. Some of it has been changed locally to a semibituminous variety by the intrusion of igneous rocks.

The coals of this district have been affected apparently by both regional and contact metamorphism and they differ in character through a wide range. Some are very hard and tough, as has been shown in the descriptions of localities. The differences in character are well indicated by the curve between Nos. 52 and 70 of figure 37, page 211, and some strange anomalies occur. Thus at locality No. 64a the sample was collected at the outcrop. The coal is relatively soft although apparently fresh, and the heating value-14,953 British thermal units-is much greater than would naturally be expected from coal collected at the surface. On the other hand, the sample from locality No. $64 \mathrm{~b}$ was collected from a prospect opening where the coal appeared to be fresh and because of its hardness is locally called anthracite. Although the bed is stratigraphically higher than that represented by No. 64a, the coal appeared in the field to be much superior to it, but analysis shows that it is much inferior for it has a heating value of only 13,567 British thermal units.

Another anomaly is presented at locality No. 66. This coal is so tough that it forms a small ledge in the bed of the stream and blocks of it form rounded bowlders and pebbles in the bed of the canyon. Yet measured by its heating value (13,930 British thermal units) it is considerably inferior to other coals of this district. At locality No. 70 the coal has been metamorphosed to a semibituminous by a sheet of igneous rock that was intruded into the sedimentary beds a few feet above the coal.

The coal of the Floresta field is hard, bright, clean anthracite. It lies in rocks of fresh-water origin near the base of the Paonia 
member of the Mesaverde formation and probably was originally a soft, low-grade, subbituminous coal similar to the unmetamorphosed Paonia coals of the Grand Mesa field on the west. The change was obviously brought about by the upheaval of the Anthracite Range. The shale that underlies the coal and is in direct contact with the igneous rock is not greatly metamorphosed, and it seems improbable that the change in the coal was due to heat derived from the igneous intrusive. On the other hand, there has been a large amount of mechanical movement in the upturned sedimentary rocks. The shearing movements that took place in the coal probably caused its metamorphism.

In the Mount Carbon field the lowest two beds of coal are well known through mining operations that have been carried on in this field for many years near the town of Mount Carbon, but little is known of the occurrence or character of the higher coals. Two mines, the Alpine and the Kubler, both opened in bed No. 2, were in operation at the time of investigation, and many other small mines have been operated to some extent as shown in the descriptions of ocalities, pages 148-160. Development work was in progress at the La Plant mine in coal bed No. 1, and this coal had been opened in several places.

Coal bed No. 1 is in the Bowie member of the Mesaverde formation, the other coals of the Mount Carbon field are in the Paonia member, but the great differences in the quality of coals in these members, as noted in the Grand Mesa field, do not obtain here, possibly because of the metamorphic influence of the igneous intrusives. The coals are relatively hard, clean, slightly coking bituminous coals. The sample collected from locality No. 85 (analysis No. 8620) is from the lowest bed or coal No. 1, but its low heating value is undoubtedly due in some measure to the weathered condition of the coal. The sample from locality No. 81 also is from coal bed No. 1 but is from perfectly fresh coal, and the analysis (No. 8619) should be regarded as representing the coal of this bed.

The samples from localities No. 87 and No. 100 are from operating mines in coal bed No. 2 and represent the Paonia coal of the Mount Carbon field. But since these localities are only $1 \frac{1}{2}$ miles and 1 mile respectively from the edge of the Mount Carbon laccolith, it is probable that the excellent quality of the coal as shown by the analyses is due in some measure to metamorphism. The sample from locality No. 105 is also from coal No. 2 but farther from the laccolith. The coal at locality No. 110 is close to the igneous rock of Mount Wheatstone and has been raised by metamorphism to the anthracite class. The coals of the Mount Carbon field thus range from bituminous to anthracite and differ in quality according to their position with reference to the igneous intrusives. In general the highest class 
coals are nearest to the laccoliths. This is shown graphically in figure 32 , page 177 , locality No. 85 being farthest from the laccolithic bodies and No. 110 nearest to one of them. However, the coal seems to have been influenced less by the heat from these bodies than by the rock movements accompanying their intrusion. In other words, the changes in the character of the coals are due principally to regional metamorphism rather than to contact metamorphism.

Regional metamorphism is much more conspicuously shown in the Crested Butte field than in any other part of the Grand Mesa and West Elk Mountain coal fields. At locality No. 113 the coal lies almost in contact with the intrusive rock of the Mount Wheatstone laccolith and yet it is not greatly metamorphosed. In fact, it is as low a grade of bituminous coal as was found in the Crested Butte field. From this locality along the outcrop toward the northwest the coal becomes more and more metamorphosed up to anthracite. This course leads away from the great igneous intrusives and toward the principal regional uplift of the mountain range in this field. The movements producing the rock structure of the Crested Butte field also have doubtless had great influence on the quality of the coals. Northwest of Crested Butte the rocks rise on the flanks of the Treasury Mountain uplift, and southeast of this town they rise toward the Wheatstone laccolith. A syncline has thus been formed whose trough lies in the vicinity of Crested Butte. This trough marks the zone of transition from bituminous to anthracite coal; on the northwestern limb of the syncline the coals are anthracite, on its southwestern limb they are all bituminous. The Crested Butte mine is in this transition zone and, as was described on page 187, shows a transition within the developed area from a semicoking bituminous coal at one side of the mine to an anthracite at the other side.

\section{BURNING OF COAL AT OUTCROP.}

The coals of Grand Mesa are burned along the outcrop in many places. Indeed where the rocks are well exposed, it is difficult to find coal at the surface. In place of it the rocks are reddened by the heat from the burning coal, and in some places they have been melted and form "clinker." Where the coal is protected at the outcrop by a covering of soil or slide rock, it has taken fire in fewer places. In the Palisades and Rollins districts, where the coals are low-grade subbituminous, the burning in the exposed slopes has been general'. Farther east, where the coals have been hardened by the metamorphic influences of the igneous mountains, burned areas are rarely found. Because of their exposure to the hot sun the southward facing slopes about Grand Mesa become dry and do not support enough vegetation to hold the soil in place. The rocks consequently have become exposed, and the coal is generally burned along the outcrop. The 
northward-facing slopes are not parched so quickly by the sun and are more completely clothed with brush the roots of which hold the soil, and this in turn protects the underlying rocks. On these slopes the coal has not been burned so generally as it has been on the southward-facing slopes.

The belief is very general that the fires were started by the spontaneous ignition of the coal. There seems to be proof that fires have been started in some coal fields in this way, and there is good evidence that some mines have taken fire in the same manner, but apparently the theory of spontaneous ignition of the coal has been too generally accepted. Careful observations were made in this field for evidence bearing on this question, and although coal was found in all stages of weathering, ranging from freshly exposed faces to beds of slacked coal that must have been exposed for many years, not a single place was found where the coal at a natural exposure showed any indication of heating. It is a well-known fact that dampness favors spontaneous ignition, yet in the Grand Mesa field the coal in the southward-facing slopes, which are dry, is burned much more generally than that in the damp northward-facing slopes. This is well illustrated in Plate VII, $A$, page 100 , which shows a southwardfacing slope at the left in which the coals are generally burned, although the same beds in the northward-facing slopes at the right are burned very little. The coals of the dry, exposed slopes would be ignited by forest fires much more readily than those of the damp, soil-protected slopes, and in the writer's opinion the burning of the coal in Grand Mesa is more likely due to forest fires than to spontaneous ignition.

\section{SURFACE INDICATIONS OF CHARACTER OF COAL.}

In places where no coal appears at the surface for long distances along the outcrop, either because of burning or because of a covering of slide rock and brush, as is often the case in the Grand Mesa field, it is an advantage to the prospector to know what kind of coal he is likely to find before going to great expense in driving entries. Many of the prospect entries in this field were driven 50 to 100 feet or more before coal was found in an undisturbed condition. In the greater part of the field the sedimentary rocks have not been greatly disturbed, and the prospector can determine with a fair degree of accuracy, by means of the fossil evidence described in this bulletin, whether high-grade or low-grade coal is to be expected at a given locality. Without known exception those coal beds in the Grand Mesa field that are associated with fossils of marine and brackish-water originthe coals of the Bowie shale-are relatively high-grade bituminous coals. With few exceptions the coals associated with fossil plants and with shells of fresh-water origin-the coals of the Paonia shale- 
are relatively low-grade bituminous or subbituminous coals. At the eastern end of the Grand Mesa field and in the smaller fields of the West Elk Mountains, where the coals have been more or less metamorphosed, no such evidence is needed, for there all of the coals are high-grade bituminous or anthracite.

Bowie coal.-Few recognizable fossil plants except the seaweed Halymenites described below have yet been found in the Bowie shale member of the Mesaverde. The relatively high-grade coals of this member are usually associated with certain fossil shells that are easily recognized, and without a single known exception in this field the coal in rocks that contain these shells is high-grade bituminous. In order to make this fact available to men who are interested in the development of the coal, the most common forms are figured in the accompanying Plates XV and XVI (pp. 222, 224).

Probably the fossil that will be most useful to the prospector is Halymenites major. It is the most abundant and widely distributed of all the fossils in this field, and although it occurs in the upper part of the Mancos shale and sparingly in some of the sandstone layers of the Bowie shale it is found most often in the Rollins sandstone which always occurs immediately below the lowest coal bed. The casts of these fossils have a pitted appearance somewhat resembling a corncob and they are frequently called petrified corncobs. They are supposed to be fucoids, a kind of seaweed, and have been referred to frequently by men who have described the coal fields of the Rocky Mountain region. The term, fucoidal standstone, has been used often in describing the Rollins or basal sandstone of the coal-bearing formations. Halymenites are so common in the Rollins sandstone that a. very small exposure of it can usually be identified by means of them. Many of the successful prospect openings examined in the Grand Mesa field were started at the top of this sandstone in places where no coal was seen at the surface.

Of the eight species of shells shown in Plates XV and XVI, the largest and most conspicuous ones are the Inoceramus. The two Inoceramus species figured in Plate XV come from a level lower than the coal, but the same species are found in many places at the top of the Bowie shale. The specimens found at the higher horizons are often very large. The two shells of Cardium speciosum figured in Plate XVI also come from a horizon lower than the lowest coal. More nearly perfect forms were found at this horizon than at the higher levels, but recognizable specimens were found in many places within the coal-bearing rocks of the Bowie shale.

Probably the fossil shells most often found in the coal-bearing rocks of the Bowie are those of oysters. Ostrea subtrigonalis (see Pl. XVI, fig. 5) is yery common and occurs sometimes singly and sometimes in dense masses together with other species. In many places 
in the Somerset and Coal Creek districts the oysters form a shell limestone 1 to 5 feet thick, which occurs near the base of the coal-bearing rocks. On Minnesota Creek a common form associated with the oysters is the spiral shell, Melania insculpta (see Pl. XVI, fig. 3). Perfect shells of this form are not often found but the species is readily recognized, even from small fragments, by the peculiar markings of the surface. Fragments were noted in many places and interior casts showing spirals. with smooth surface are common.

The two shells of Corbula undifera and Corbicula cytheriformis (Pl. XVI) were found in many places near the base of the coal-bearing rocks, and great numbers of them were found in the roof shale of some of the coal mines. In this shale they are usually flattened and appear as chalky white impressions, the shell having been reduced to a soft lime.

Paonia coal.-Photographs of the fossil shells most likely to be found in the Paonia shale are shown in Plate XVII. Corbula subtrigonalis, figure 5 of this plate, occurs also in the Bowie shale but is most abundant near the base of the Paonia. The other forms range from the base of the Paonia to the top of the Mesaverde.

The range of the fossil plants in the Grand Mesa field is the same as that of the fresh-water shells, but they are more uniformly distributed. Most of them were collected from the Paonia shale, because much more time was spent examining the coal-bearing rocks of this member than was spent on the higher non-coal-bearing rocks. However, fossil plants were observed in many places near the top of the Mesaverde.

All of the species shown in Plates XVIII to XXI are common in the Paonia, but two species, a palm and a fig, can be especially useful to the prospector because they are so readily recognized. Good specimens of the palm leaves, Geonomites ungeri, are not as numerous as some other forms, but fragments are found in many places. If the center of the leaf is found, it can be identified by comparison with figure 3 on Plate XVIII. The outer parts of the leaf are recognized from the corrugated surface, which somewhat resembles the face of a washboard. The most common fig leaf, Ficus speciosissima (Plate XIX) is recognized by its peculiar and prominent veins. Even a small fragment can be identified. (See Plate XVIII, fig. 1.) There was scarcely a locality that was examined with care in the Grand Mesa field where this fig leaf was not found. The other fossil leaves described are equally useful to the prospector when they are found, but they are less conspicuous than the two just named. 

PLATE XV. 


\section{PLATE XV.}

InVertebrates From the UPPER PART OF the MANCOS SHale.

Figure 1. Inoceramus barabini Morton. Natural size. Mesozoic locality record of the United States Geological Survey No. 4270.

2. Mactra formosa $\mathrm{M}$. and $\mathrm{H}$. Natural size. Mesozoic locality record of the United States Geological Survey No. 4490.

3. Inoceramus sagensis Owen. Natural size. Mesozoic locality record of the United States Geological Survey No. 4208. 


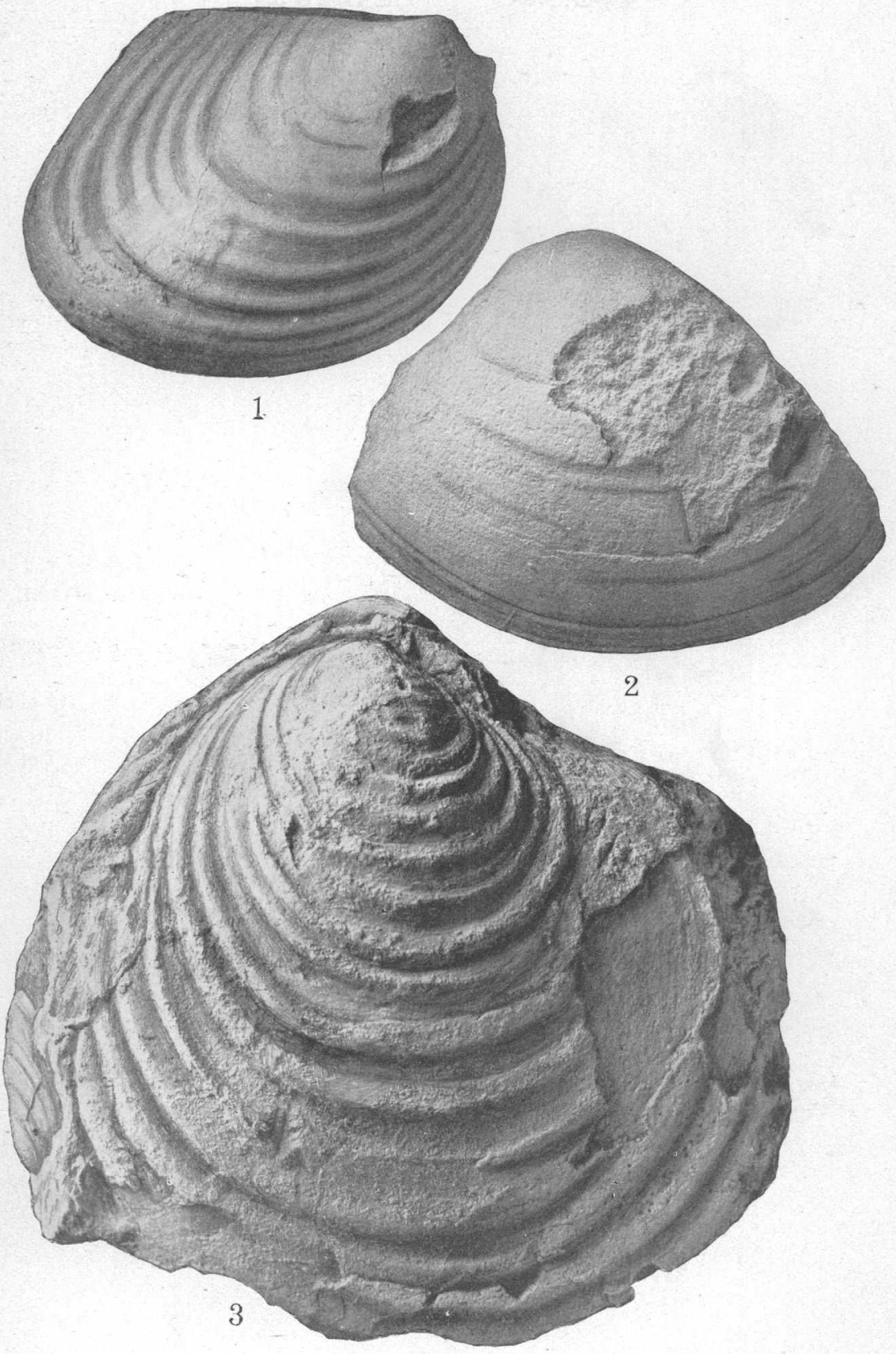

INVERTEBRATES FROM THE UPPER PART OF THE MANCOS SHALE.

The same fossils occur in the rocks containing the high-grade bituminous coal of the Grand Mesa field. 
PLATE XVI. 


\section{PLATE XVI.}

\section{Fossils associated With the High-GRADE BITUMINOUS COALS OF the Grand Mesa field (From the Bowie shale Member of the Mesaverde Formation).}

Figures 1-2. Cardium speciosum M. and H. Natural size. Mesozoic locality records of the United States Geological Survey Nos. 4490 and 4496; upper part of Mancos shale. (The specimens figured are chosen from this locality because they are better preserved than those collected from the Bowie shale.)

3. Melania insculpta Meek. Natural size. Mesozoic locality record of the United States Geological Survey No. 4499; near the base of the Bowie shale.

4. Corbula undifera Meek. Natural size. Mesozoic locality record of the United States Geological Survey No. 4266; base of the Bowie shale, in shale overlying a bed of coal.

5. Ostrea subtrigonalis E. and S. Natural size. Mesozoic locality record of the United States Geological Survey No. 4273; near the base of the Bowie shale.

6. Corbicula cytheriformis M. and H. Natural size. Mesozoic locality record of the United States Geological Survey No. 4275; near the base of the Bowie shale.

7. Halymenites major Lesq. Natural size. Near the top of the Bowie shale. 

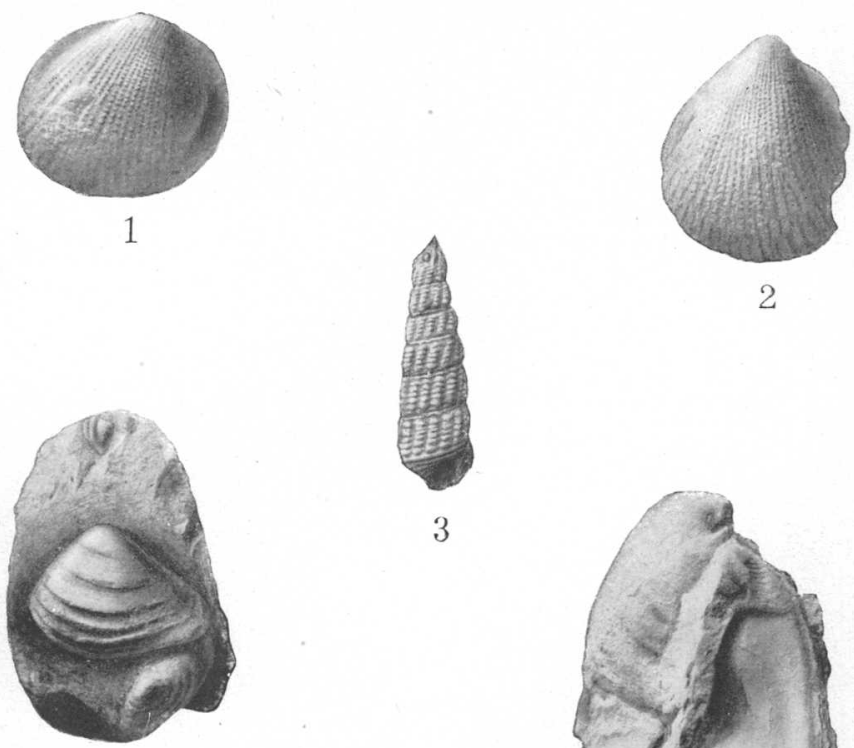

4
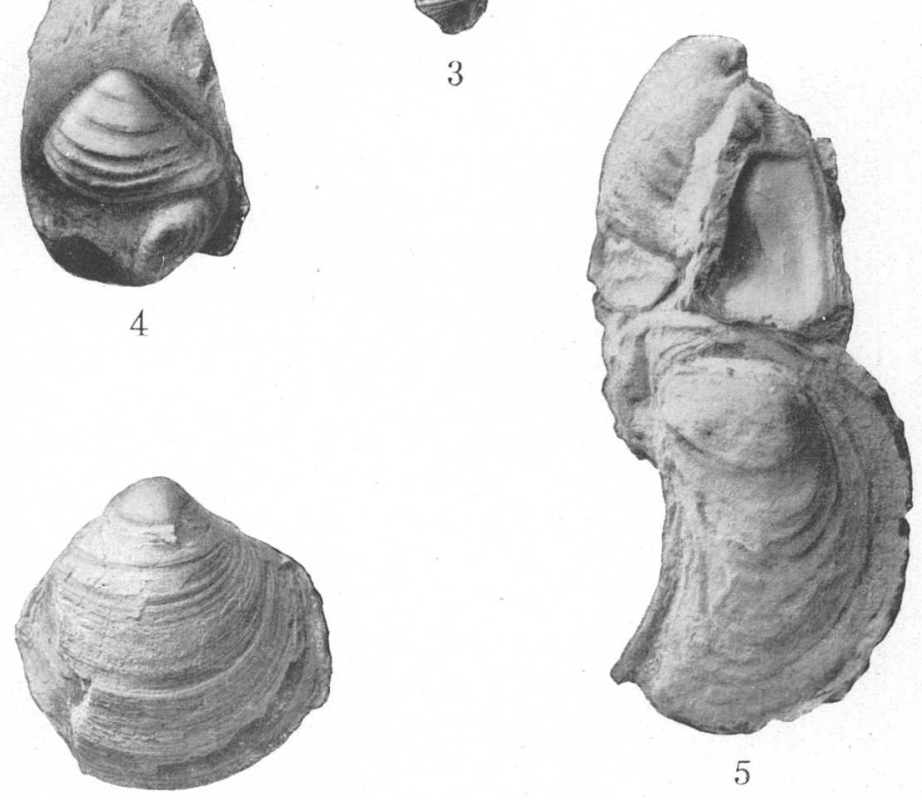

6

3

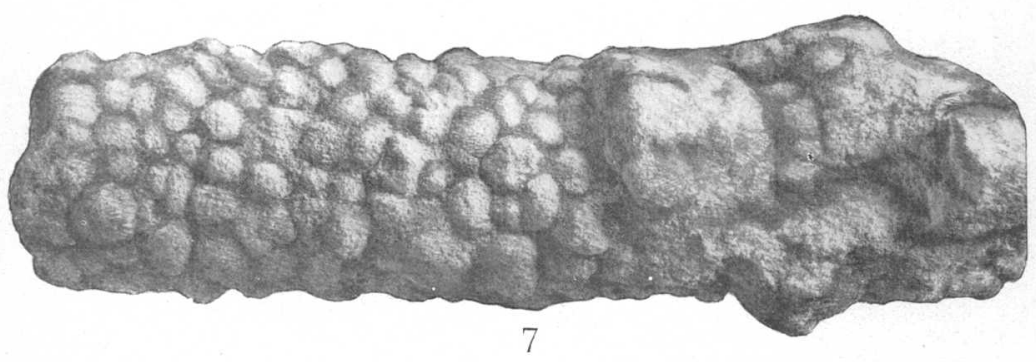

FOSSILS ASSOCIATED WITH THE HIGH-GRADE BITUMINOUS COALS OF THE GRAND MESA FIELD. 


\section{PLATE XVII.}

$40642^{\circ}-$ Bull. $510-12-15$ 


\section{PLATE XVII.}

Fossils AsSOcIATED WITH THE LOW-GRADE BITUMINOUS AND SUBbitumiñous coals of the Grand Mesa field (invertebrates from the Paonia shale member of the Mesaverde formation).

Figure 1. Campeloma? sp. Natural size. Mesozoic locality record of the United States Geological Survey No. 4221; about 200 feet above the base of the Paonia shale.

2. Unio cf. brachyopisthus White. Natural size. Mesozoic locality record of the United States Geological Survey No. 4221; about 200 feet above the base of the Paonia shale.

3-4. Tulotoma thompsoni White. Natural size. Mesozoic locality records of the United States Geological Survey Nos. 4221 and 4220; about 200 feet above the base of the Paonia shale.

5. Corbula subtrigonalis M. and H. Natural size. Mesozoic locality record of the United States Geological Survey No. 4250; 75 feet above the base of the Paonia shale.

6. Unio cf. endlichi White. Natural size. Mesozoic locality record of the United States Geological Survey No. 4220; about 200 feet above the base of the Paonia shale. 

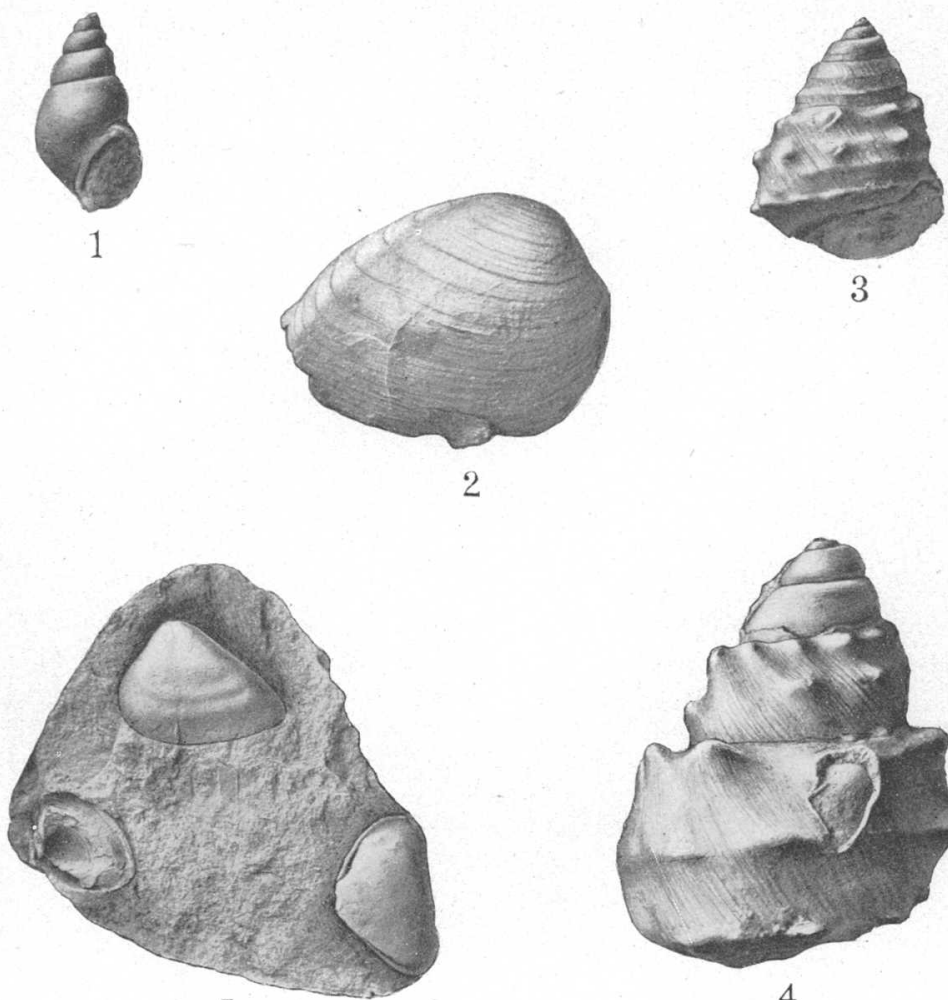

5
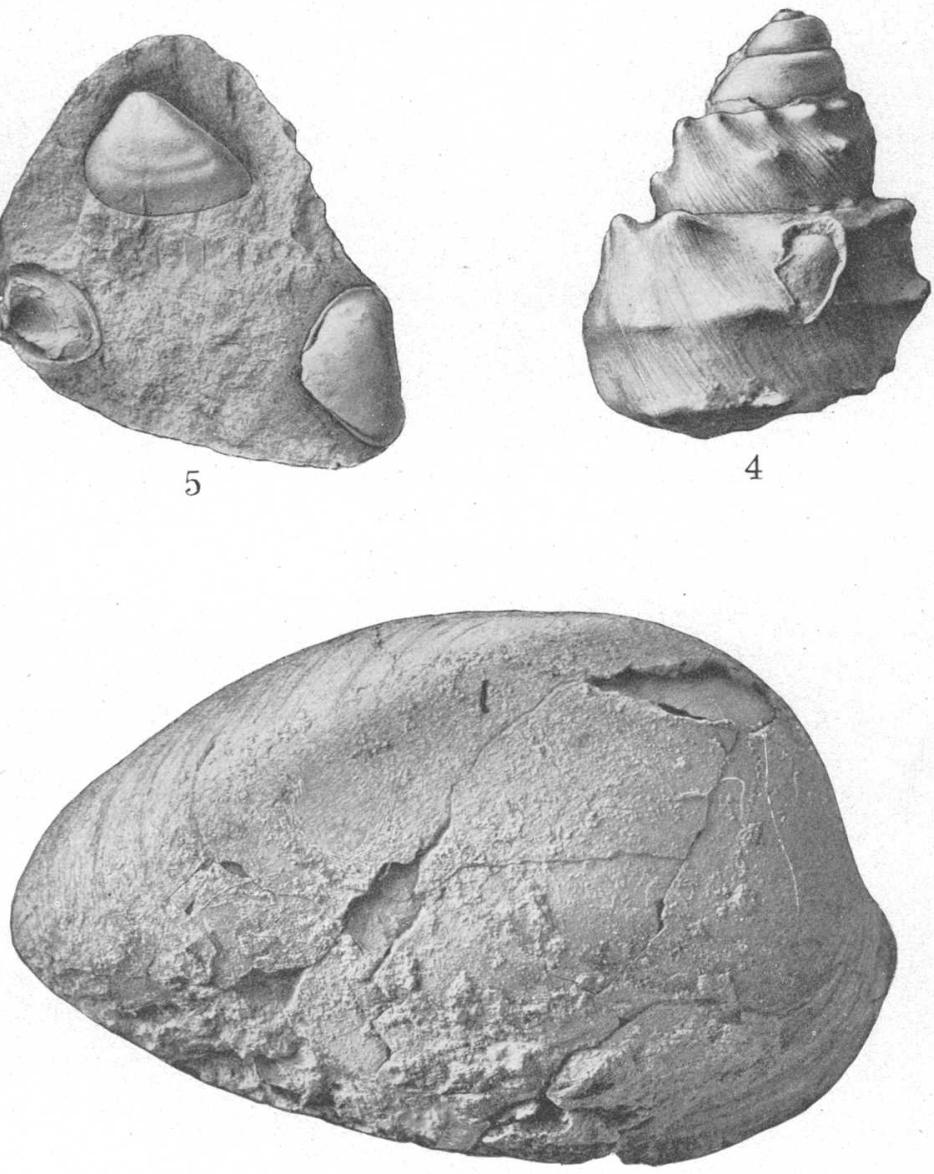

6

FOSSILS ASSOCIATED WITH THE LOW-GRADE BITUMINOUS AND SUBBITUMINOUS COALS OF THE GRAND MESA FIELD. 
PLATE XVIII. 


\section{PI.ATE XVIII.}

Fossil Plants associated WITH THE LOW-GRAdE BITUMINoUs AND subbituminous coars of the Grand Mesa fIELd (From the Paonia shale member of the Mesaterde formation).

Figure 1. Fragments of Myrica torreyi Lesq. (natural size) and Ficus speciosissima Ward. Fossil plant locality record of the United States Geological Survey No. 4383.

2. Myrica torreyi Lesq. Natural size.

3. Geonomites ungeri Lesq. Palm leaf. Natural size. Fossil plant locality record of the United States Geological Survey No. 4336. 


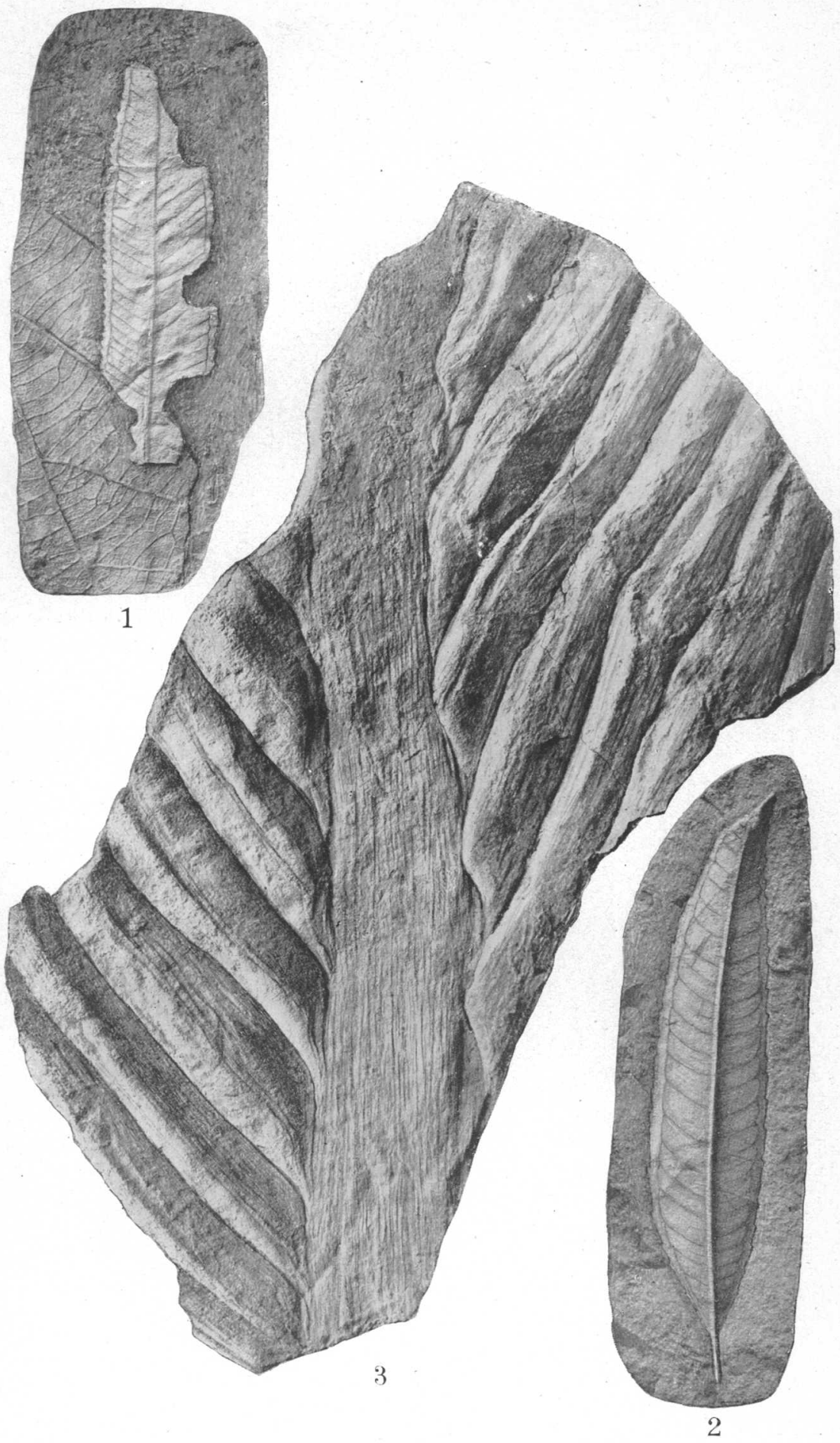

FOSSIL PLANTS ASSOCIATED WITH THE LOW-GRADE BITUMINOUS AND SUBBITUMINOUS COALS OF THE GRAND MESA FIELD. 
PLATE XIX. 


\section{PLATE XIX.}

A fossil plant (Ficus speciosissima Ward) associated with the LOW-GRADE BITUMINOUS AND SUBBITUMINOUS COALS OF THE Grand Mesa Field.

A fossil leaf common in the Paonia shale member of the Mesaverde formation. Fossil plant locality record of the United States Geological Survey No. 4352. (Slightly reduced.) 


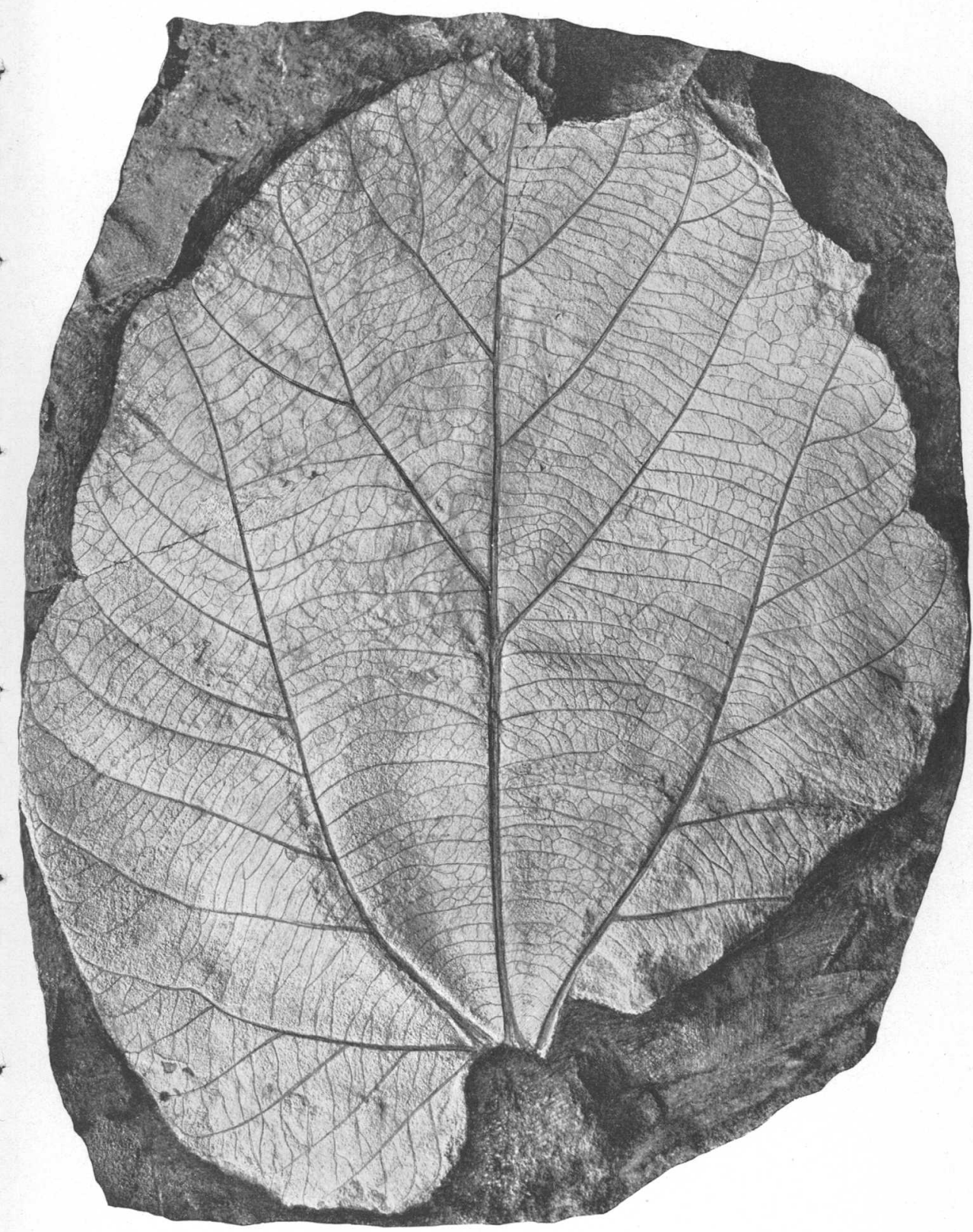

A FOSSIL PLANT ASSOCIATED WITH THE LOW-GRADE BITUMINOUS AND SUBBITUMINOUS COALS OF THE GRAND MESA FIELD. 


\section{PLIATE XX.}




\section{PLATE XX.}

Fossil plants associated WITH THE LOW-GRAde BITUMinous AND SUbBituminous coals of THE Grand Mesa Field (From the Paonia shale member of the Mesaverde formation).

Figure 1. Ficus trinervis Knowlton. Natural size. Fossil plant locality record of the United States Geological Survey No. 4353.

2. Ficus planicostata Lesq. Natural size. Fossil plant locality record of the United States Geological Survey No. 4345.

3. Pteris Russelli Newb. Natural size. Fossil plant locality record of the United States Geological Survey No. 4337. 


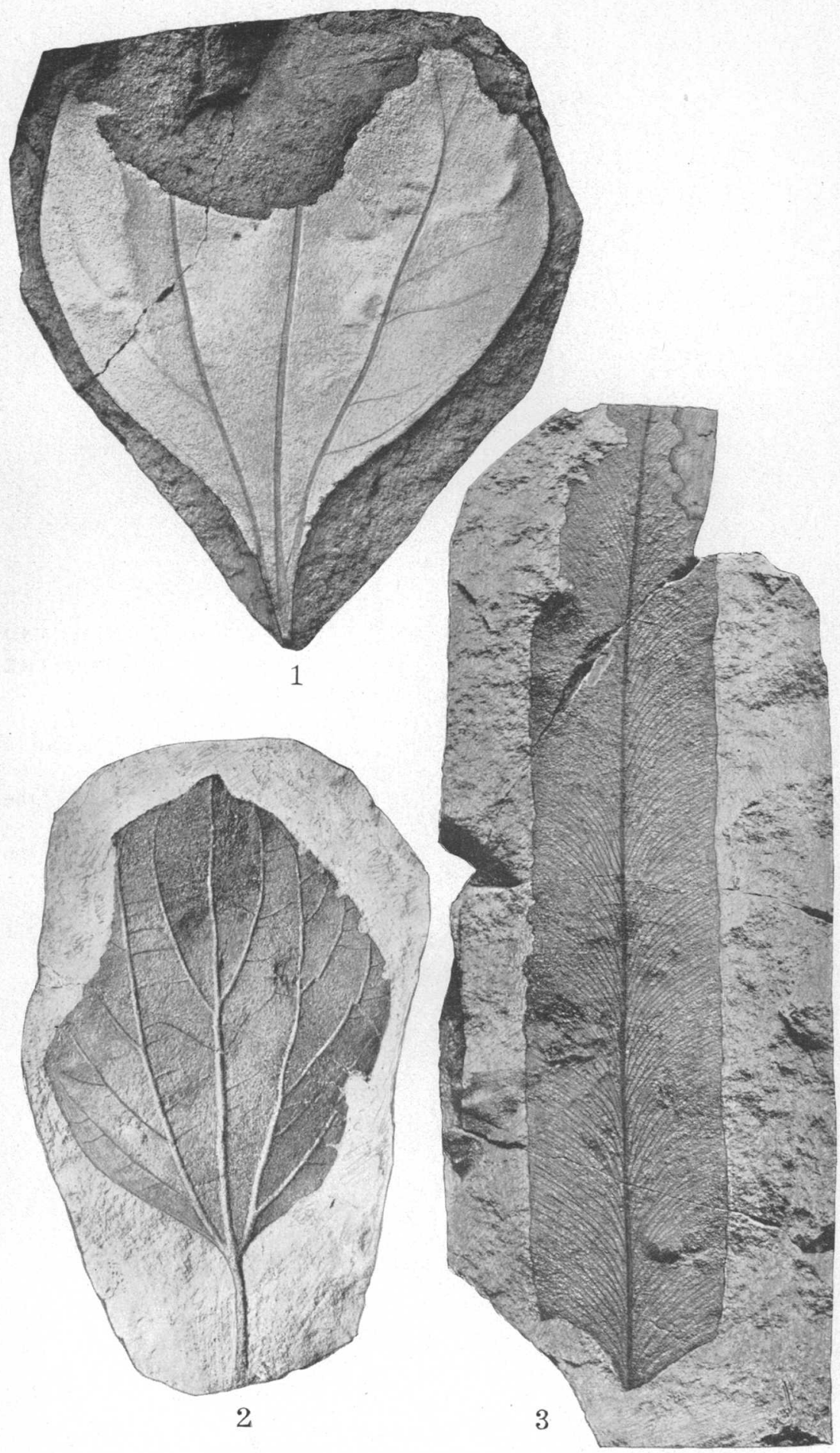

FOSSIL PLANTS ASSOCIATED WITH THE LOW-GRADE BITUMINOUS AND SUBBITUMINOUS COALS OF THE GRAND MESA FIELD. 
PLATE XXI.

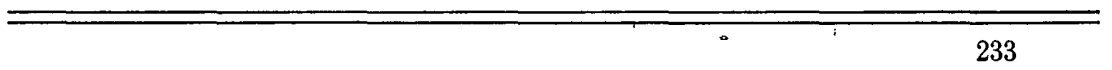




\section{PLATE XXI.}

\section{A fossil plant (Magnolia tenuinervis) associated With the LOW-GRADE BITUMINOUS AND SUBBITUMINOUS COALS OF THE Grand Mesa field.}

From the Paonia shale member of the Mesaverde formation. Fossil plant locality record of the United States Geological Survey No. 4348. (Natural size:) 


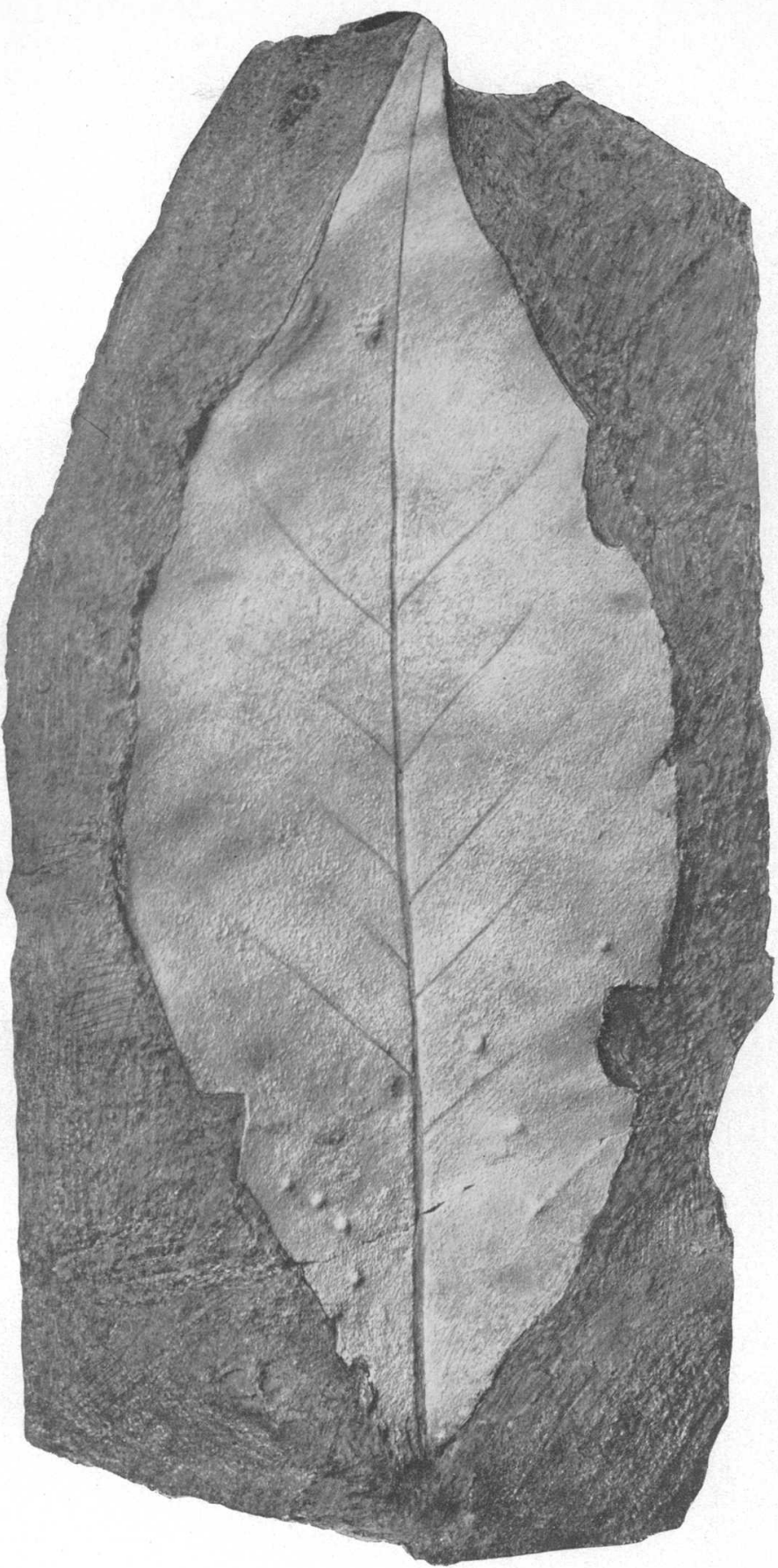

A FOSSIL PLANT ASSOCIATED WITH THE LOW-GRADE BITUMINOUS AND SUBBITUMINOUS COALS OF THE GRAND MESA FIELD 


\section{INDEX.}

A. Page.

Acknowledgments..................... 13

Alpine mine, description of. ............ 152-155

coal in, sections of, figure showing ...... 154

Analyses of coals, results of............. 201-209

Anthracite Mesa, structure of .............. 59

Athracite mine, description of.......... 195-196

Anthracite quadrangle, description of....... 58-62

Axtell, Mount, structure of................ 61

\section{B.}

Bailey mine, description of ............... 76 section in......................... $\quad 77$

Baldwin mine, description of............. 158

Basalt, occurrence of...................... $\quad 57$

Baxter Basin, plate showing .............. 194

Baxter Gulch, coal beds on.............. 175-176

Beckwith, Mount, structure of ............. 60

Bennett mine, description of.............. 92

Blair, C. S., acknowledgment to............ 13

Blossom mine. section in................ 89

Bowie shale member, coal in. $66,80-81,95,98-99,150$ coal in, sections of, figure showing...... 80 coals from, analyses of........... 204-206,210 description of....................... 32-38 fossils from ................. 32-36, 218-219 plate showing .................... 224 sections of, figure showing .............. 50

Bryan, R. R., acknowledgment to.......... 13

Bulkley mine, description of............. 176-179

Burdick mine, description of . ............. 176-179

Burning of coal at outcrop............... 216-217

\section{C.}

Cameo coal bed, description of............. $75-76$ sample from....................... 80

Campbell, M. R., acknowledgment to....... 13

Carbon, Mount, map and section of......... 153

Plate showing..................... 146 structure of ......

Carbon, Mount, field, coal in............. 144-167 coal in, character of ................. 215-216 coals from, analyses of ..... 148, 159, 206-207, 208 drill prospect in, record of ............ 150 sections in. 151,156, 158,161, 162, 163, 164, 165, 166 sections in, figure showing........... 147, $154,156,157,159,163,167$ situation of ........................ 8 surface features of .................... 16

Castle, The, plate showing .............. 146

Cliff Creek canyon, plate showing ......... 112

Cliff, The, plate showing ................ 113

Coal, character of ..................... 210-216 character of, surface indications of..... 217-219 occurrence of, in the Mancos shale...... 65-66 occurrence of, in the Mesaverde formation. $66-67$
Coal beds, position of, in the Crested Butte mine, figure showing.......... 185

Coal Creek canyon, landslide in, plate showing........................ 128 sections in. 120,122,123,124, 128, 129, 131, 134, 135

Coal Creek district, boundaries of.......... . 68 coal in.......................... 112-139 coal in, character of.................. 214 sections of ...................... 116 figure showing....... 117, 118,119,122, 120 coals from, analyses of ............ 205-203 Coking tests, results of, on Juanita coal .... 104-105 Collection of samples, method of.......... 199-200 Conine mine, description of............... 100 section in......................... 100

Cooperative mine. See Paonia Coal Co.'s mine.

Corner marks, absence of................. 10-12

Crested Butte, plate showing ............... $\quad 170$

Crested Butte field, coal in ............. 168-198 coal in, character of.............. 211-212,216 coals from, analyses of........... 207,208-209 sections in ........................ 176

$178,180,185,188,190,192,193,194,197,198$ figure showing..... 171, 173,177, 184, 196, 198 situation of ................, . . . . . 8,9 surface features of ...................... 17 Crested Butte mine, description of......... 181-1.87 plate showing ....................... 194 Crested Butte quadrangle, description of..... 62-63 Cross, Whitman, quoted.................. 56

\section{D.}

Dakota sandstone, description of........... 23-24 sections of, figure showing............. .50

Davis mine, section in................. $\quad 89$ Deer Creck, coal on................... 71-72 De Golyer, E. L., acknowledgment to...... 13 Degrafenreid mine, section in............... 91 Dorrance mine, description of ............. 101

E.

Eldridge, G. H., quoted......... 24, 49, 58-63, 196

F.

Fairview mine, description of . . . . . . . . . $85-87$ section near...................... 85-86

Floresta, Colo., section at................ 139

Floresta field, coal in ................... 139-143 coal in, character of................. 214-215 coals from, analyses of ......... 206-207, 208-209 drill prospects in, records of, figure showing......................... 141 sections in, figure showing............ 140 
Floresta field, situation of ............ Page. surface features of ................. 16

Fossils from Bowie shale member. . . . 32-36, 218, 219 from Bowie shale member, Plate showing 224 from Crested Butte field . . . . . . . . . 187-188, 189 from Mancos shale................. 27, 28 plate showing ................ 222

from Mesaverde formation, undifferentiated part of ............... 44-47

from Mount Carbon field ........ 150, 151, 165 from Paonia shale member . . . . . . 39, 30-43,219 plate showing ....... 226, 228, 230, 232, 234 from Rollins sandstone member....... 32 Wasatch, from Book Cliffs

G.

Gelwick mine, description of 102-103

Gibson Ridge, plate showing............. 170

Grand Mesa, west slope of, plate showing... 15 coal field, map showing .............. 7,8 , also $\mathrm{Pl}$. I (in pocket). section of, plate showing ...... Pl. I (in pocket). situation of . .................... 9 structure of................ 57-58,63-65 surface features of ................... 13-16

Grand River valley, section in . . . . . . . 74-75

Green River formation, description of ...... 51

Gunnison Canyon, sections in ......... 22, 23-24 north wall of, plate showing. $\ldots \ldots \ldots \ldots 22,48$

Gunnison district, boundaries of ......... 67 coal in .......................... 68-73 character of ................... 212

sections of, figure showing ......... 69 coal-bearing rocks in, figure showing.... $\quad 70$ coals from, analyses of ............... 201

Gunnison formation, description of . . . . . 21-23 section of, figure showing.

Gunnison, Mount, rocks north of, plate show ing $\ldots \ldots \ldots \ldots \ldots \ldots \ldots \ldots \ldots \ldots \ldots, 48$ plate showing $\ldots \ldots \ldots \ldots \ldots \ldots \ldots \ldots \ldots, 112$ sections east of $\ldots \ldots \ldots \ldots \ldots \ldots \ldots \ldots 122,126,127$ structure of

Gunnison River, North Fork of, canyon of, plate showing.

H.

Hall mine, fossils from section in

mine, description of

Hazelwood, A. J., acknowledgment to...... Hubbard Creek canyon, section in......... 97

\section{I.}

Igpeous rock, general features of ......... 52-53 intrusive sheet of, plate showing ....... 113

\section{J.}

Johnson, H. D., acknowledgment to....... 13 Johnson prospect, section near............ 108 Juanita coal bed, coal from, coking tests on. 104-105 description of . . . . . . . . . . . . . . . . . 98-99 prospects in. 105-106

R.

Kahnah Creek, coal on ................ 71,80

King mine, new opening, description of.... 103-104 new opening, section in ........... 103 old opening, description of........... 102
Page.

Knowlton, F. H., acknowledgment to...... 13 quoted $\ldots \ldots \ldots \ldots \ldots \ldots \ldots \ldots \ldots \ldots \ldots \ldots .45-47$

Kubler mine, description of . . . . . . . . . . . 160-162

Kuhnley mine, description of . . . . . . . . . . 82-84 section in ..................... 82

L.

La Plant mine, description of . . . . . . . . . . 149-150 section in ....................... 149

Landerth mine, section in ............... 91

Little Coal creek, coal on . .............. 111

Lombard, Mount, plate showing........ 112

M.

McGruder mine, section in ............... 90

Mallott's prospects, description of . . ..... 105-106 sections of ............................ 106

Mancos shale member, coal in .......... 65-66 coals from, analyses of .............. 201

description of . ................... 25-28

fossils from . .................... 27, 28 plate showing .................... 222 occurrence of $\ldots \ldots \ldots \ldots \ldots \ldots \ldots \ldots \ldots \ldots 62,63$ plate showing .................. 22 sections of, figure showing........... 50

Maroon conglomerate, description of ....... 20-21

Mertie, J. B., acknowledgment to . . ....... 13

Mesaverde formation, coal in . ..........66-67 coals from, analyses of ......... 202,206-207 description of . .................... 29-30 occurrence of . . . . . . . . . . . . . $61-62,62-63$ sections of, figure showing ........... 79 undifferentiated part of, description of. . 43-45 fossils in..................... 44-47 sections of, figure showing ......... $\quad 50$ upper part of, plate showing.......... 14 Metamorphism, changes in coal from . ..... 210-216 relation of character of coal to, figure showing.................... 211

Methods of work, description of. . . . . . . . 10-12

Mining, method of, in the Alpine mine..... 155

in the Conine mine... .............. 100

in the Crested Butte mine........... 186-187

in the King mine............... 103-104

in the Kubler mine.................. 161

in the Paonia Coal Co.'s mine. . . . . . . . 101-102

in the Porter mine. ................ 180-181

in the Rollins mine. ............... 84-85

in the Ruby-Anthracite mine......... 143

in the Silverbrook mine. . . . . . . 188-189,190

Minnesota Creek, section on . ............. 97-98

Mosley, S. L., information from . ......... 138 prospects of . .................... 128

Mosley mine, description of . . . . . . . . . 120-121 section at. . ........................ 120

Mount Carbon. See Carbon, Mount.

N.

Newman mine, description of 92-93 O.

Oh-be-Joyful Gulch, coal on . ............ 192-193

Ohio Creek conglomerate, description of. . . . 48-49 occurrence of . . . . . . . . . . . . . sections of, figure showing ........... 50 
P.

Page.

Paine Mesa, west slope of, plate showing....

Palisades, Colo., coal-bearing rocks south of, plate showing promontory south of, Plate showing.....

Palisades district, boundaries of. coal in.

character of. coals from, analyses of

Paonia, Colo., coal-bearing rocks east of, plate showing ............... 100

Paonia Coal Co.'s mine, description of.... 101-102 section in .......................... 102

Paonia shale member, coal in ............. $66-67$, $75-80,81,140,152,165,169-170$ coal in, sections of, figure showing...... 77 coals from, analyses of .......... 202-203, 210 description of....................... 38-43 fossils from. $39,40-43,219$

plate showing ........ 226, 228, 230, 232, 234 sections of, figure showing............. 50

Patterson mine, section in................. 78

Phillip mine, description of............. 110-111 section near........................ 110

Porter claims, description of............. 107-110 Porter mine, description of .............. 179-181

\section{Q.}

Quantity of coal, estimate of.............. 198-199 Quartz monzonite porphyry, description of.. 53-56

R.

Riverside mine, section in ............... 80

Robinson Canyon, plate showing ............ 112

Robinson Creek, coal beds near.......... 137-138

North Fork of, coal bed on, section of... 138

Robinson mine, description of........... 165-167

Rockefeller, J. H., information from........ 138 prospect of ...................... 135

Rollins district, boundaries of ............. 67 coal in........................... 81-94 character of.................. 212-213 coal-bearing rocks in, sections of, figure showing .............

Rollins mine, description of.............. 84-85 sections in........................ 84,85

Rollins sandstone member, description of... 30-32 fossils in plate showing sections of, figure showing.............. 50

Ruby- $\Lambda$ nthracite mine, description of..... 140-143 plate showing
Ruby formation. See Wasatch formation. Ruby Range, structure of.............. 59-60

S.

Schuylkill Mountain, plate showing........ $\quad 170$

Sedimentary formations, section of......... 18-19

Shoecroft prospect, description of.......... 109

Siebenthal, C. E., acknowledgment to....... 24

Silverbrook mine, description of .......... 188-190

Simonton prospect, section at............ 109

Slate River, coal on................ 192, 193, 194

Somerset district, boundaries of............ 67-68

coal-bearing rocks in, sections of, figure showing..................... 96

coal in ........................... 94-110

character of.................... 213-214

coals from, analyses of.............. 204-205

Somerset mine, description of............. 106

Stanton, T. W., acknowledgment to........ 13

quoted........................... 36,43

States mine, description of................ $\quad 90$ section of ......................... 90

Stokes mine, section in................. 81

Stratigraphy, general statement on........ 17-20

Stucker mine, description of............... 93-94 section in.......................... 94

Stucker prospect, section in............... 94

Sylvester opening, description of.......... 106-107

$\mathrm{U}$.

Uinta coal region, location of.............. 7

W.

Wadsworth Canyon, section in............ 132 section in, flgure showing............. 133

Ward (Loomis) mine, section in........... 91

Wasatch formation, description of......... 49-51 sections of, figure showing............ 50

Water supply of Grand Mesa field.......... 15-16

Watson mine, description of.............. 88 section in........................... 88

Wells Gulch, coal in................... 72

West Elk breccia, description of........... $\quad 56$

West Elk Mountain coal field, map showing........... 7,8 , also $\mathrm{Pl}$. I (in pocket). section of, plate showing......Pl. I (in pocket). structure of.......................... 58-63

Wheatstone, Mount, plate showing........ 170 structure of......................... 61

Winton mine, description of............. 87-88 Woodruff, E. G., acknowledgment to....... 69 